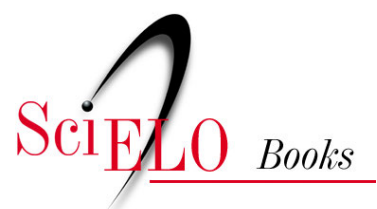

\title{
Conflitos, eficiência e democracia na gestão pública
}

\author{
Douglas Gerson Braga
}

BRAGA, DG. Conflitos, eficiência e democracia na gestão pública [online]. Rio de Janeiro: Editora FIOCRUZ, 1998. 193 p. ISBN 978-85-85676-53-1. Available from SciELO Books <http://books.scielo.org>.

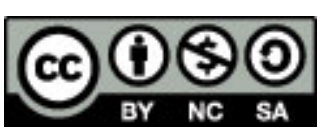

All the contents of this work, except where otherwise noted, is licensed under a Creative Commons Attribution-Non Commercial-ShareAlike 3.0 Unported.

Todo o conteúdo deste trabalho, exceto quando houver ressalva, é publicado sob a licença Creative Commons Atribuição Uso Não Comercial - Partilha nos Mesmos Termos 3.0 Não adaptada.

Todo el contenido de esta obra, excepto donde se indique lo contrario, está bajo licencia de la licencia Creative Commons Reconocimento-NoComercial-CompartirIgual 3.0 Unported. 


\section{Conflitos,}

EFICIENCIA E

\section{Democracia na}

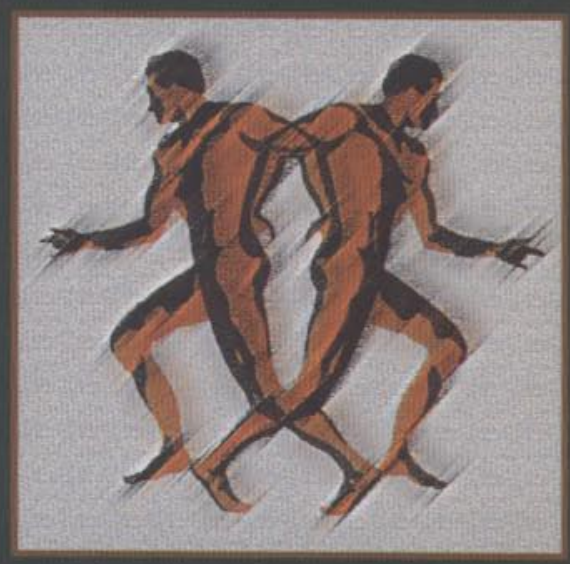

GESTÃO PÚBLICA

Douglas Gerson Braga

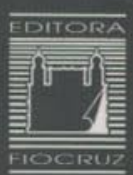




\section{Conflitos,}

\section{EFICIENCIA E}

\section{Democracla na}

GESTÃO PÚBLICA 


\section{FUNDAÇĀO OSWALDO CRUZ}

Presidente

Paulo Marchiori Buss

Vice-Presidente de Desenvolvimento Institucional, Informação e Comunicação

Paulo Gadelha

\section{EDITORA FIOCRUZ}

Coordenador

Paulo Gadelha

Conselho Editorial

Carlos E. A. Coimbra Jr.

Carolina M. Bori

Charles Pessanha

Jaime L. Benchimol

Jósé da Rocha Carvalheiro

José Rodrigues Coura

Luis David Castiel

Luiz Fernando Ferreira

Maria Cecília de Souza Minayo

Miriam Struchiner

Paulo Amarante

Vanize Macêdo

Zigman Brener

Coordenador Executivo

João Carlos Canossa P. Mendes 


\section{Conflitos,}

\section{EFICIENCIA E}

Democracla na

\section{GESTÃO PÚBLICA}

\section{Douglas Gerson Braga}

$1^{\text {a Reimpressão }}$

Coordenador de Pesquiso

Dovid Broga Júnior

Contribuiţōo e Participaçāo

Organizaçõo Mundial da Saúde

Organização Pan-Ámericona da Saúde

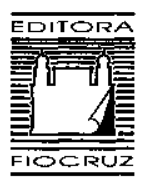


Copyright (C) 1998 by Douglas Gerson Braga

Direitos autorais cedidos à Ação da Cidadania contra a Miséria e pela Vida

Todos os direitos desta edição reservados à

FUNDAÇÃO OSWALDO CRUZ / EDITORA

ISBN: 85-85676-53-1

1 edição: 1998

13 reimpressão: 2002

Capa e Projeto Gráfico: Heloisa Diniz

Editoração Eletrônica: Heloisa Diniz e Guilherme Ashton

Revisão: Fernanda Veneu

Copidesque e Preparação de Originais: M. Cecilia Gomes Barbosa Moreira

Catalogação-na-fonte

Centro de Informação Científica e Tecnológica

Biblioteca Lincoln de Freitas Filho

\section{B813c Braga, Douglas Gerson}

Conflitos, eficiência e democracia na gestão pública / douglas Cerson Braga. - Rio de Janeiro : Editora FIOCRUZ, 1998. 193p., tab.

1. Setor público. 2. Gestão de qualidade total.

$$
\text { CDO - 20.ed. }-658.4013
$$

2002

Editora Fiocruz

Av. Brasil, $4036-1^{\circ}$ andar - sala 112 - Manguinhos

21040-361 - Rio de Janeiro - RJ

Tels.: (21) $3882-9039$ e 3882-9041

Telefax: (21) 3882-9006 e 3882-9007

http://www.fiocruz.br/editora

e-mail: editora@fiocruz.br 
Com muita alegria, recebi de Betinho o texto da orelha deste livro. À sua memória dedico este livro.

Faço uma homenagem e um agradecimento especial ao irmão David médico, professor e dirigente de instituiçōes de saúde - pioneiro na compreensăo do conceito de eficiência condicionada à democratizaçăo dos meios empregados para seu alcance. Sem sua competência e ousadia administrativa, modelos democráticos de gestão não teriam saído do papel.

De coraçăo, agradeço a Ayda Tereza Sonnesen Losso e a Julio Cesar Macedo Amorim.

Destaco os apoios da Coordenação Geral de Desenvolvimento de Recursos Humanos para o SUS e do INSS/SP, órgäos dos Ministérios da Saúde e da Previdência e Assistência Social, respectivamente.

Este trabalho é resultado do empenho e da colaboração de instituiçōes públicas e do compromisso de servidores públicos, administradores e dirigentes sindicais com os legitimos interesses da cidadania. 


\section{SUMÁRIO}

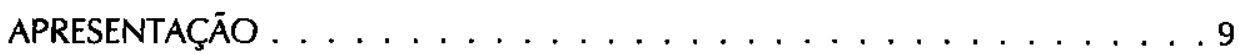

1. PROPOSIÇŌES RESULTANTES DO TRABALHO . . . . . . . . . . . 15

1.1. Doutrina, Análise Técnica e Sustentação Jurídica da Forma Padronizada de Convênio . . . . . . . . . . . . . . . . . 16

1.2. Conteúdo para Convênios em Geral: modelo sugerido . . . . . . . . . 23

1.3. Conteúdos para Legislação . . . . . . . . . . . 26

2. ROTEIRO EM SEIS PASSOS PARA IMPLANTAÇÃO

DE SISTEMAS DE GESTÃO . . . . . . . . . . . . . . . . . . 35

2.1. Diagnóstico e Definição de Premissas para Introdução de Mudanças . . . 36

2.2. Definição de Atores e seus Papéis . . . . . . . . . . . 38

2.3. Providências Preliminares . . . . . . . . . . . . . 38

2.4. Configuração do Sistema . . . . . . . . . . . . 39

2.5. Constituição do Sistema . . . . . . . . . . . 45

2.6. Formalização dos Resultados . . . . . . . . . . . . . . . 57

3. ANÁLISES DE MODELOS DE GESTĀO . . . . . . . . . . . . . 75

3.1. Aos Sindicatos Combativos: uma consideração política . . . . . . . . . 76

3.2. Assuntos Relacionados à Prefeitura do Município de São Paulo . . . . . . . 81

3.3. Assuntos Relacionados à Área da Saúde . . . . . . . . . . . . . . . . 102

3.4. A Negociação Coletiva com Suporte Legislativo no Município de Campinas . . . . . . . . . . . . . . . . . 122

3.5. Assuntos Relacionados à Previdência Social . . . . . . . . . . . . . . 129

4. A NEGOCIAÇÃO DE CONFLITOS EM ÉPOCA DE ESCASSEZ

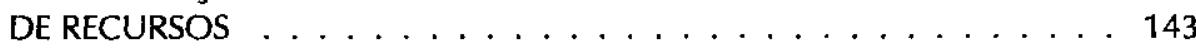

4.1. introdução . . . . . . . . . . . . . . . . . . . . . . 145

4.2. Conceituação . . . . . . . . . . . . . . . . . . . 149

4.3. O Processo de Negociaçăo . . . . . . . . . . . . . . . . . . . 157

4.4. Posições Táticas e Técnicas da Negociação . . . . . . . . . . . . . 164

COMENTÁRIOS FINAIS: DÚVIDAS MAIS COMUNS . . . . . . . . . . . . 189 


\section{Apresentação}

\section{Conquistar o Estado Democrático e Social de Direito}

Cabe ao conjunto da sociedade brasileira garantir que o Estado possa prover condições essenciais para o exercício da cidadania. Os servidores públicos, especialmente, devem cumprir à risca essa tarefa, por ser imperativo ético, moral e legal.

Contudo, fatores como a consolidação histórica de um Estado autoritário, sua condução política distante das demandas sociais, o quadro de deterioração do aparelho administrativo, a desarticulaçăo da sociedade civil, aliados a uma cultura de serviços que náo releva os interesses-fim da Administração Pública, têm dificultado a construçăo da cidadania.

Saúde, Previdência Social e Educação, entre outras, são peças essenciais ao exercício da cidadania. Cabe, especialmente, aos servidores públicos e às instituições que trabalham para a consolidação da democracia social em nosso país uma parcela considerável de responsabilidade na condução desta tarefa. Igualmente, açốes concretas de governo articulando os demais segmentos interessados devem constituir prioridade nacional.

Nesse contexto, inserem-se diversas iniciativas para instituir sistemas de gestão participativa e qualificativa dos serviços públicos. Trata-se da adoção de um novo conceito de gerenciamento das relações de trabalho no setor público. Um instrumento para democratizar e promover o desenvolvimento combinado destas relações, com metas e objetivos comuns previamente acordados e definidos entre os vários protagonistas.

Tais sistemas têm por substrato promover o envolvimento, a integração e a participação do conjunto dos servidores nos assuntos de interesse comum, por intermédio da participação organizada de suas entidades sindicais. Buscam, também, estimular o crescimento das taxas de controle social e de exigência de qualidade por parte da comunidade usuária dos serviços.

Seu propósito fundamental é, no entanto, promover e direcionar o desenvolvimento das relaçōes de trabalho e o tratamento dos seus conflitos, utilizando, como referência, o objetivo comum de prestar e atender - com qualidade, eficácia e democracia - aos serviços e às demandas da cidadania em benefício da dignidade da pessoa humana.

Eis, portanto, o objeto fundamental do qual se ocupará este livro. 


\section{Sistematização de experiências}

O primeiro objetivo deste trabalho consiste em sistematizar e democratizar experiências de tratamento de conflitos e o desenvolvimento das relaçōes de trabalho no setor público, em uma perspectiva de qualificação dos serviços prestados à população. Foram processos introduzidos a partir de 1988, por intermédio da instituição de sistemas de negociação e de gestões participativas, dos quais pude participar diretamente, sempre na condição de convidado.

O segundo objetivo é contribuir para a implantação prática de projetos dessa natureza, especialmente na área da Seguridade Social, razão pela qual o trabalho assume certa forma didática e não se propõe a aprofundar, no plano teórico, os temas tratados.

\section{Combinação de fórmulas}

A necessidade de novos mecanismos de gerenciamento, abordagem e desenvolvimento das relaçōes de trabalho no setor público, na perspectiva anteriormente apontada, obriga-nos a repensar a administração pública e a elaborar propostas adaptadas às diferentes situações legais com as quais coabitam essas relações. E também força especialistas e estudiosos desses assuntos a atuarem segundo uma lógica que determina a adoção de iniciativas combinadas, umas voltadas para mudanças legislativas, de fundo; outras, mais pragmáticas, voltadas para aplicação imediata, nas condiçōes legais já estabelecidas; todas, porém, direcionadas para a obtenção de resultados concretos e para intervenções nos campos do comportamento e da cultura estabelecida no meio.

Os modelos sugeridos segundo esta concepção concretizam-se na formalização de documentos contendo procedimentos acordados, princípios e normas reguladoras dessas relaçōes, subscritos pelas partes interessadas. Este conjunto de regras pode ser instituído por intermédio da celebração de convênios, contratos ou, ainda, por meio de legislação apropriada. É esta a matéria-prima utilizada na confecção do livro.

Diante disto, propusemo-nos a analisar três formas diferentes de aplicação desses novos conceitos, todas desenvolvidas com fulcro no princípio participativo e na necessidade permanente de concretização dos mais elementares direitos da cidadania, amplamente apregoados pela Constituiçăo Federal de 1988.

\section{Modelo contratual}

Uma primeira forma estudada adapta-se mais às relaçốes regidas pela Consolidação das Leis do Trabalho (CLT), ainda encontradas no setor público. Trata-se do modelo contratual, que se assemelha aos institutos oriundos do Direito do Trabalho. As teses favoráveis à aplicação deste modelo ganharam força no período imediatamente posterior à promulgação da Constituição de 1988, com a instituição do direito de organização sindical conquistado pelos servidores públicos. Contudo, crescem cada vez mais as resistências ao modelo contratual puro, desacompanhado de legislação de suporte. As principais características desse modelo estão presentes no Sistema Permanente de Negociação Coletiva de Trabalho do IAMPSE, ${ }^{1}$ razão pela qual esta experiência será objeto de cuidadosa análise.

1 Instituto de Assistência Médica ao Servidor Público Estadual, Coverno do Estado de Săo Paulo, 1988. 


\section{Convênios}

A forma de convênio, na qual aparece mais explícita a combinação favorável à consecução das finalidades administrativas, com ênfase total na questão dos direitos dos usuários, é integralmente sustentada em princípios e normas que informam e regem o Direito e a Administração Pública. As experiências aplicadas por meio deste modelo não encontraram as resistências de caráter jurídico apostas ao modelo contratual. São ilustrativas do modelo apresentado sob o formato de convênio as seguintes experiências, descritas e estudadas neste livro: Sistema de Gestão Qualificativa das Relações de Trabalho e dos Serviços da Seguridade Social ${ }^{2}$ e Convênio do Sistema de Gestão Participativa do INSS. ${ }^{3}$

\section{Legislação de suporte}

A introdução do modelo de gerenciamento participativo e qualificativo das relaçōes de trabalho e dos serviços públicos, por meio de legislação de suporte, em caráter nacional, tem esbarrado na ausência de vontade política das instâncias competentes. Invariavelmente, esta matéria surge 'de carona' em projetos legislativos mais amplos. Portanto, em nível nacional, ainda não foi testada a posição dos diversos agentes políticos, especificamente sobre este assunto. A regulamentação legislativa já foi experimentada, em alguns casos, conforme se demonstrará, especialmente por intermédio das experiências: Estudos e Propostas para Implantação de Sistema Permanente de Negociação e Contratação Coletiva de Trabalho, ${ }^{4}$ Negociação Coletiva e Legislação Municipal em Campinas, ${ }^{5}$ Sistema Democrático de Relações de Trabalho, ${ }^{6}$ Resoluções do Conselho Nacional de Saúde e Decreto Ministerial (1994).

É bom ressaltar que a regulação legislativa da matéria não será suficiente para assegurar mudanças efetivas no comportamento dos agentes políticos e administrativos e, conseqüentemente, gerar qualidade para as relaçöes de trabalho e para os serviços públicos. Mas será, sem dúvida, fundamental para responder às principais resistências que são apostas a modelos desse tipo, capitaneadas por áreas jurídicas mais conservadoras.

\section{Contratos, convênios e legislaçāo de suporte}

Conhecer e estudar determinados modelos, ainda que possam ser considerados como superados, é imprescindível para compreender melhor o tema e avançar na formulação e na implementação de novos projetos. Das três formas comentadas, a

2 Ministérios da Saúde e da Previdência e Assistência Social, 1995.

3 Instituto Nacional do Seguro Social, São Paulo, 1993.

4 Prefeitura do Municipal de Săo Paulo, 1992.

5 Prefeitura Municipal de Campinas, 1992.

6 Proposta de novo modelo de relaçōes de trabalho, de introduçăo de sistema permanente de negociação coletiva no setor público e de instituição do Conselho Nacional de Administração Pública, Central única dos Trabalhadores (CUT), 1992. 
ênfase maior será para os convênios, mais compativeis com normas e procedimentos próprios da Administração Pública. Sua aplicação, combinada com eventual aprovação de legislação de suporte sobre a matéria, para reforçar os objetivos e conferir certa uniformidade ao sistema, apresenta-se, aqui, como a fórmula ideal.

Não se pode esquecer, contudo, que a celebração de convênios voltados às finalidades visadas não depende de prévia autorização legislativa, conforme demonstram os estudos Doutrina, Análise Técnica e Sustentação Jurídica da Forma Padronizada de Convênio, apresentados mais adiante.

Ressalte-se, por fim, que a proposta de legislação de suporte, específica para a área de Saúde, estaria contemplada em caso de aprovação de legislação de suporte, de caráter geral para a Administração Pública, nos termos propostos. Contudo, é mostrada aqui por apresentar possibilidades para que se promova a implementação de projetos dessa natureza em grau de prioridade.

Parte dos estudos a serem apresentados foram desenvolvidos, inicialmente, para o Núcleo Técnico Multiprofissional para a Qualificação de Recursos Humanos, do qual participamos, constituído no âmbito do Ministério da Saúde, cuja finalidade era promover o desenvolvimento do projeto Gestão Participativa para a Qualificaçăo das Relações de Emprego, de Trabalho e dos Serviços da Seguridade Social. Esse projeto contou com a colaboração do Ministério da Previdência e Assistência Social, por intermédio do INSS/SP e apoio da Organização Mundial (OMS) e Organização Pan-Americana da Saúde (OPS). ${ }^{7}$

\section{Metodologia}

O trabalho foi organizado e dividido em cinco capítulos. No primeiro, reuniu-se conteúdo para responder, com objetividade, ao que sempre se pergunta de forma simples e direta: o que se propõe? Apresentam-se proposições atuais de legislação de suporte e de modelo de convênio, seus fundamentos jurídicos e os elementos de sustentação doutrinária da forma padronizada de convênio. No capítulo 2, procura-se contribuir para solucionar a questão: como introduzir no setor público novas propostas de gestão? O Roteiro em Seis Passos para Implantação de Sistemas de Gestão foi a forma encontrada para estimular a aplicaçăo prática desses modelos. Compilaram-se experiências verificadas sob o formato contratual ou conveniado, protocolos prévios de compromissos, protocolos de resultados e demais instrumentos dessa natureza. No capítulo 3, propôs-se demonstrar que avaliação se faz de modelos de gestão já conhecidos. A resposta são estudos e análises de caráter conceitual e político. Também foram reunidas as experiências legislativas. No capítulo 4, reuniu-se material para solucionar outra dificuldade bastante comum: como negociar conflitos de interesse em época de escassez de recursos? São abordadas, especificamente, técnicas de gerenciamento e tratamento de conflitos. Funciona, na prática, como complemento do Roteiro em Seis Passos: instituído um modelo de gestáo participativa, como colocá-lo em

7 Integraram também o Núcleo Técnico Multiprofissional os médicos David Braga júnior, josé Carlos Oliveira, José Paranaguá de Santana e Roberto Passos Nogueira. 
funcionamento no dia-a-dia da Administração Pública? Para cumprir essa tarefa, optou-se pela tradução de material mais apropriado. No último capítulo, incluíram-se comentários finais e um tópico em que estão contidas as dúvidas mais comuns sobre o tema, em forma de perguntas e respostas.

É necessário esclarecer a seqüência dos assuntos aqui tratados. Com efeito, escolhemos começar o trabalho com o que consideramos mais atual e consistente em termos de proposta concreta sobre o tema. As proposições sugeridas no início resultaram dos estudos elaborados sobre as diversas experiências arroladas, posteriormente, no próprio livro. Há, portanto, uma inversão proposital na ordem de apresentação desse assunto para destacar o avanço e a evolução da matéria e a definição conceitual do autor sobre a forma mais adequada de introdução desses modelos de gestão.

Em razão de seu caráter, considera-se coletiva a autoria deste trabalho. Por este motivo, serão registrados os autores, quando for o caso, ao final de matérias e documentos citados. 


\section{Proposições Resultantes do Trabalho}

A forma de organização adotada neste livro segue uma lógica muito particular. O que poderia ser apresentado como resultado final dos estudos consta da primeira parte, precedendo os elementos pesquisados que lhes deram sustentação.

Escolheu-se esta forma de apresentação por vários motivos. Um deles foi a percepção de que novas proposições, formuladas de maneira cuidadosa, com linguagem técnica mais consistente, e mais bem apoiadas jurídica e doutrinariamente, estimulam a clientela interessada.

Outro argumento de peso refere-se à clássica resistência dos oponentes à introduçăo desses modelos de gestão e gerenciamento dos serviços públiços. A base de argumentação desses setores localiza-se na crítica à aplicação de institutos do Direito do Trabalho junto à esfera administrativa. Com as peças apresentadas no capítulo 1, desmitifica-se essa crítica e comprova-se ser plenamente possivel, sem perder de vista os objetivos centrais desses projetos, sustentá-los, fundamentalmente, nos institutos, princípios e normas do Direito Administrativo.

Por este motivo, busca-se, desde logo, demonstrar que a matéria evoluiu para a neutralização da oposição entre regras do Direito Administrativo e institutos do Direito do Trabalho. Por isso, a primeira peça deste capítulo cuida da Doutrina, Análise Técnica e Sustentação Jurídica da Forma Padronizada de Convênio e se faz acompanhar de modelos de convênios e de proposiçōes de legislação de suporte, material parcialmente aplicado nas experiências desenvolvidas. 


\title{
1.1. DOUTRINA, ANÁLISE TÉCNICA E SUSTENTAÇÃO JURÍDICA DA FORMA PADRONIZADA DE CONVÊNIO
}

\author{
Toda pessoa tem direito à verdade. \\ O servidor năo pode omiti-la ou falseá-la, \\ ainda que contrária aos interesses da própria pessoa \\ interessada ou da Administração Pública. \\ Nenhum Estado pode crescer ou estabilizar-se \\ sobre o poder corruptivo do hábito do erro, \\ da opressão ou da mentira, \\ que sempre aniquilam até mesmo a dignidade humana \\ quanto mais a de uma Naçāo. ${ }^{1}$
}

\section{Introdução}

O Núcleo Técnico Multiprofissional para Qualificação de Recursos Humanos, mencionado na Apresentação, desenvolve estudos para implantação de projetos para desenvolver as relaçóes de emprego e de trabalho no setor público, em uma perspectiva de qualificação dos serviços demandados pela cidadania. Para tanto, propõe a adoção do Sistema de Gestão Qualificativa das Relaçōes de Emprego, de Trabalho e dos Serviços Públicos ${ }^{2}$ e sua aplicação por meio de convênios, entre os diversos órgãos da Administração Pública e entidades civis e sindicais.

É este o objeto desses estudos.

A análise da proposta de celebração de convênios para introduzir o Sistema de Gestão Qualificativa (SGQ), no setor público, será realizada à luz dos princípios e das normas legais que informam o Direito e regem a Administração Pública, bem como dos aspectos doutrinários envolvidos. Para tanto, o trabalho será dividido em duas partes. A primeira abordará, sinteticamente, os elementos nucleares indispensáveis aos procedimentos administrativos. Constituirão referenciais a serem aplicados na verificação da adequação do SGQ às normas administrativas. A segunda parte procederá à verificação propriamente dita desta adequação. Serão abordadas, ainda, as questões referentes à conveniência administrativa e política para a introdução destes convênios.

\section{Princípios que Regem a Administração Pública}

Entre os princípios a serem cotejados para se verificar a correta adequação de determinados atos ou procedimentos administrativos, três merecem destaque. São os princípios da legalidade, da supremacia do interesse público e da moralidade administrativa, que serão registrados de forma bastante resumida.

1 Código de Ética Profissional do Servidor Público Civil do Poder Executivo Federal. Decreto $n^{\mathbf{2}} 1.171$, de $22 / 06 / 94$, VIII.

2 Após a análise técnica, apresentam-se o modelo de convênio proposto e sugestões legislativas. 


\section{Legalidade}

Todos sabemos que o princípio da legalidade está na base do Estado de Direito. Entre os particulares, vige o princípio da autonomia da vontade, segundo o qual o que não for proibido por lei é permitido. Diferentemente, o administrador público age sob o império das leis. Só pode fazer o que a lei lhe permite. "Suporta a lei que fizeste" é a proposição recomendada pelo sempre mestre, José Cretella Júnior (1992), ao asseverar que todos os princípios estão fundamentados no princípio da legalidade.

\section{Supremacia do Interesse Público}

Alguns identificam este princípio com o da finalidade, outros, com o da impessoalidade. Contudo, o que importa, segundo os ensinamentos de Celso Antônio Bandeira de Mello (1994), é que "o princípio da supremacia do interesse público sobre o interesse privado é princípio geral de direito inerente a qualquer sociedade. É a própria condição de sua existência".

Acrescenta Diógenes Gasparini (1992) que "nem poderia ser de outro modo, uma vez que todo poder emana do povo e, por evidente, em seu nome e benefício será exercido", referindo-se ao disposto no artigo $1^{\circ}$ da Constituição Federal.

\section{Legalidade + Finalidade $=$ Moralidade}

"A moralidade da Administração Pública não se limita à distinção entre o bem e o mal, devendo ser acrescida da idéia de que o fim é sempre o bem comum. $O$ equilíbrio entre a legalidade e a finalidade, na conduta do servidor público, é que poderá consolidar a moralidade do ato administrativo." ${ }^{3}$

\section{Caráter, Objetivos e Fundamentos do Estado}

Sabe-se que, segundo o princípio da legalidade, o administrador público age em função daquilo que ihe prescreve a lei. Verificamos que, sob o império das leis, a Administração Pública nada mais é que instrumento para atingir os objetivos do Estado. Neste caso, há que se verificar, na Lei Máxima-a Constituição da República-o caráter, os fundamentos e os objetivos do Estado brasileiro e considerar, para o administrador público, o dever de ser seu primeiro observador.

3 Código de Ética Profissional do Servidor Público Civil do Poder Executivo Federal - Decreto $n^{2} 1.171$, de 22/06/94, III. 


\section{Caráter}

"A configuração do Estado Democrático de Direito", firmada no artigo 10 da Constituição Federal, como destaca José Afonso da Silva (1992), "consiste, na verdade, na criação de um conceito novo que leva em conta os conceitos dos elementos componentes, mas os supera na medida em que incorpora um elemento revolucionário de transformação do status quo".

Reforçou-se, assim, a partir da Constituição de 1988, o caráter democrático do Estado, em contraposição à situação anterior. Houve, portanto, mudanças. Ao determinar a democratização política do Estado, a Constituição aponta para a adoção de uma concepção democrática de administração pública para harmonizar os meios e os fins almejados.

\section{Fundamentos e Objetivos do Estado}

Ainda no artigo $1 \%$, prescreve-se, na Constituição, que o Estado brasileiro tem seus alicerces em valores como cidadania e dignidade da pessoa humana, para citar apenas os que se situam em nosso campo de análise.

"Construir uma sociedade livre, justa e igualitária", erradicar a pobreza, reduzir desigualdades sociais, promover o bem de todos são alguns dos objetivos explicitados no artigo $3^{\circ}$. Construir algo pressupöe que ele não existe. Há, portanto, que se promover mudanças para que Estado e sociedade possam viabilizar estes novos objetivos.

\section{Finalidade da Administraçāo Pública}

Analisando-se os princípios e dispositivos constitucionais comentados, pode-se concluir que a finalidade primeira da Administração Pública deve ser prestar com qualidade, eficácia e democracia, os senviços e atender às demandas que the são legalmente requeridas pela sociedade, em benefício da cidadania e da dignidade da pessoa humana.

Adotar procedimentos para atingir estes objetivos é dever primordial dos administradores públicos. Omitir-se, inibir, ou frustrar tais procedimentos fere, sobretudo, os princípios da indisponibilidade do interesse público e da legalidade. Como ensina Celso Antônio Bandeira de Mello (1994), "as pessoas administrativas não têm disponibilidade sobre os interesses públicos confiados à sua guarda e realização".

\section{Sistema de Gestão Qualificativa: adequação legal}

O Sistema de Gestão Qualificativa é decorrência natural da aplicação do princípio participativo. Este, por sua vez, integra o conceito de democracia participativa, que consta da Constituição Federal. 
"O princípio participativo caracteriza-se pela participação direta e pessoal da cidadania na formação dos atos de governo", afirma José Afonso da Silva (1992). O autor registra, ainda, diversas ocasiōes em que há determinação constitucional expressa de aplicação deste princípio. Entre elas, cita a instituição dos conselhos e órgãos colegiados. E faz referências ao Título VIII, Capítulo $11,{ }^{4}$ em que se determina que a organização da Seguridade Social deve observar o "caráter democrático e descentralizado da gestão administrativa, com a participação da comunidade, em especial de trabalhadores, empresários e aposentados".

Especialmente sobre a saúde, está estabelecido que "as ações e serviços públicos de saúde integram uma rede regionalizada e hierarquizada e constituem um sistema único, organizado de acordo com as seguintes diretrizes: (...) III - participação da comunidade" ${ }^{5}$

Cotejando os conceitos que utiliza, os princípios nos quais se funda, os objetivos a serem logrados e os procedimentos que pretende adotar, verifica-se a adequação plena do SGQ às finalidades e aos princípios que informam a Adminisțração Pública, consagrados constitucional e doutrinariamente.

Com efeito, na cláusula segunda, parágrafo segundo do Convênio aplicam-se, com precisão, conceitos fundamentais do Direito Administrativo, ao se afirmar que: "Entende-se por finalidade administrativa a prestação e o atendimento, com qualidade, eficácia e democracia, dos serviços públicos e das demandas da cidadania, em seu benefício e em benefício da dignidade da pessoa humana".

Na cláusula quarta estipula-se, expressamente, obsenância aos princípios da legalidade, da moralidade e da indisponibilidade do interesse público. Já na cláusula terceira, determina-se que, entre seus postulados, objetivos e metas, o SGQ deve: "Perseguir, a título de objetivos gerais, a consecução das finalidades administrativas do setor e, a título de objetivos específicos, o tratamento dos conflitos que insurgem em seu curso e a instituiçăo de mecanismos de controle social sobre o gerenciamento dos senviços."

\section{Processo decisório}

O SCQ funcionará por meio da instituição de Mesas de Participação e Negociação Permanente. Nelas os partícipes atuarão de acordo com as regras e os procedimentos estatuídos em seu documento básico e respectivo Regimento Interno. $\mathrm{Na}$ cláusula sétima do Convênio está previsto que "a aprovação de matéria decorrente da aplicação do SGQ dependerá da posição favorável consensual dos seus partícipes".

Este sistema assegura que decisão alguma será impingida a qualquer das partes, em função da composição numérica da Mesa. Resguardam-se plenamente, assim, os interesses da Administração Pública, já que nada se aprova sem o consentimento expresso do próprio administrador. O mesmo raciocínio vale para os demais participantes, mantendo-se intacto o princípio da autonomia sindical.

4 Constituiçăo Federal, artigos 10 e 194, Parágrafo Único, VII.

5 Constitụição Federal, artigo 198. 


\section{Competência, formalização e eficácia dos resultados}

Não há restrições quanto à competência material do SGQ. As decisões adotadas, sempre consensuais, serão registradas em Atas de Reunião ou em Protocolos da Mesa de Participação e Negociação Permanente. Deste registro não decorre, necessariamente, sua implementação ou eficácia. Assim, se determinada decisão implicar encerrar uma greve, caberá ao sindicato adotar os procedimentos necessários à efetivação da medida pela categoria, única detentora desta prerrogativa.

No plano interno, a Administração utilizará a forma ou os veículos legais subseqüentes mais adequados à implementaçăo da decisão. Este veículo pode ser um ato normativo interno, como, por exemplo, uma circular ou portaria; o encaminhamento de manifestações dirigidas às instâncias competentes, até mesmo ao Congresso Nacional.

\section{Restriçōes à negociação coletiva de trabalho}

Pergunta-se se a decisão adotada pelo Supremo Tribunal Federal ${ }^{6}$ - que veda a aplicação do instituto da negociação coletiva de trabalho para o setor público - não coibiria a instituição de modelos de gestão como o que se pretende implementar.

Entende-se, aqui, que não. A decisão do Supremo foi no sentido de estabelecer uma fronteira clara entre institutos oriundos do Direito do Trabalho e do Direito Administrativo. Veio para esclarecer, principalmente, que a Justiça do Trabalho não detém competência legal para apreciardissídios coletivos do setor público. Esta prerrogativa, entre outros problemas, acarretaria conflitos de competência entre os poderes da República.

Isto está muito longe de significar que os administradores públicos estejam impossibilitados de negociar a composição de conflitos que interfiram na consecução das finalidades administrativas. Assegurados, constitucionalmente, aos servidores públicos, a mais corporativa das formas de organização (sindicatos) e o mais extremo dos meios de pressão dos assalariados (greves), não seria possível crer que o legislador ou - Poder Judiciário viessem a inibir a adoção de mecanismos para harmonizar e promover o desenvolvimento das relações de emprego e de trabalho no setor público.

$O$ fato é que os atores constitutivos das relaçōes de trabalho no setor público também precisam conversar. O SCQ institucionaliza e confere forma legal a este diálogo, construindo seus alicerces sobre os institutos oriundos do Direito Administrativo. Daí não se encontrar fulminado pela vedação da Suprema Corte.

\section{Forma e competência legal}

A forma apresentada para implantar o novo sistema é o convênio. Assim, sob este aspecto, o SCQ pode ser definido como um convênio a ser celebrado entre órgãos públicos e entidades civis que atuam ou dispõem de algum poder legal de interferência na realização dos serviços públicos.

6 STF, ADIn., $n^{9} 492-1-D F$, Rel Min. Carlos Veloso, RDT 80/168. 
Hely Lopes Meirelles (1992) nos ensina que:

Convênios administrativos são acordos firmados por entidades públicas de qualquer espécie, ou entre estas e organizaçōes particulares, para realização de objetivos de interesse comum dos partícipes (...)

Convênio é acordo, mas não é contrato. Nos contratos as partes têm interesses diretos diversos e opostos; nos convênios os partícipes têm interesses comuns e coincidentes (...)

A liberdade de ingresso e retirada dos partícipes do convênio é traço característico dessa cooperação associativa, e, por isso mesmo, não admite cláusula obrigatória da permanência ou sancionadora dos denunciantes.

Ele lembra, ainda, que no Decreto-Lei no $200 / 67$ já se recomendava a celebração de convênios para promover a descentralização administrativa. Em normas legais específicas das diversas áreas da Administração Pública, também é possível encontrar autorização expressa para sua celebração, sendo pacífica a doutrina quanto ao assunto. De resto, os convênios já integram a prática administrativa corriqueira.

Carlos Pinto Coelho Motta (1994), analisando a Lei de Licitações e Contratos Administrativos ${ }^{7}$ - em que se faz menção expressa aos convênios ao determinar-lhes, "no que couber" observância às disposições ali contidas - cita posicionamento do Tribunal de Contas da União (TCU) sobre o assunto. Por intermédio do Ministro Mário Pacini, o TCU afirma que "a distinção mais precisa entre o contrato e o convênio é quanto à reciprocidade de obrigações", lembrando que "no Convênio os interesses são comuns e a prestação em dinheiro não precisa existir". ${ }^{8}$

Igualmente, não há qualquer restriçăo legal para impedir uma organização sindical ou entidade da sociedade civil - desde que legalmente constituída - de figurar em convênios com órgãos públicos.

\section{Conveniências administrativas e políticas}

O Código de Ética do Servidor Público estabelece como dever dos servidores "participar dos movimentos e estudos que se relacionem com a melhoria do exercício de suas funções". 9

Em 10 de janeiro de 1994, foi editado o Decreto no 1.039, dispondo sobre o Sistema de Organização e Modernização Administrativa (SOMAD), que determina a necessidade básica de "desenvolver padrōes de qualidade e de racionalidade" no desempenho das atividades administrativas.

7 Lei $n^{2} 8.666$, de 21/06/93, artigo 116 .

8 TCU - 001.582-5, Diário Oficial da União de 18/09/85, p.13.651; e TCU, em 19/02/92, p.2.135.

9 Código de Ética Profissional do Servidor Público Civil do Poder Executivo Federal - Dec. $n^{0} 1.171$, de 22/06/94, XIV, letra o. 
Em diversos diplomas legais, campanhas institucionais e manifestações da sociedade civil, é possível encontrar, em abundância, referências à necessidade de estabelecer compromissos em torno de objetivos como os do SGQ.

Também a análise e aplicação de critérios políticos conduzem à conclusão de que a celebração de convênios voltados para a adoção de sistemas de gerenciamento participativo goza de absoluta legitimidade e figura no campo da vontade política dos principais mandatários da nação.

Com efeito, no Programa de Governo ${ }^{10}$ aprovado pelas urnas afirma-se, textualmente, que:

A reforma do Estado no campo da Saúde significa: agilização do processo de descentralização para estados e municipios; fortalecimento do governo federal para o exercício de suas funçōes regulatórias e de auditoria; implantação de um programa conseqüente de qualificação dos servidores públicos para esses novos papéis; e manutenção de uma burocracia estável. Isso será feito com a diminuição dos cargos de livre provimento, a estrita obediência ao princípio do mérito na carreira, oferta regular de programas de treinamento e melhoria salarial vinculada a padröes de desempenho. Deverá ainda ser priorizada a gestão participativa (grifo do autor).

\section{Conclusões}

O Convênio de Gestão Qualificativa das Relações de Emprego, de Trabalho e dos Serviços Públicos pressupõe e age sobre vasto campo de interesses comuns, muitas vezes difusos e conflituosos, encarnados pelos atores da Administração Pública. Sua ação estimula e promove a participação dos usuários. Com isto, contribui para aumentar as taxas de controle social e de exigência de qualidade. Surge daí a natureza crítico-participativo-propositiva característica deste modelo.

Tal caráter confere maior credibilidade e autoridade às ações administrativas e maior legitimidade e espaço de ação para o exercício das atividades sindicais. Para tratar de assuntos específicos, de interesse comum, é preciso discutir propostas pontuais e concretas, cuja viabilidade contribua, também, para realizar as atividades gerais da Administração Pública.

É nesse envolvimento e no reforço da credibilidade e da viabilização das finalidades administrativas que repousa o interesse maior do administrador em adotar este modelo. E é na ampliação do espaço para o exercício democrático e constitucional da atividade sindical, e no acréscimo da legitimidade, decorrentes do exercício da função propositiva e negocial, que a entidade sindical vê vantagens substanciais em sua adoção.

De resto, a instituição de modelos, como o de Gestão Participativa e Qualificativa do Setor Público, democratiza o processo decisório e confere maior eficácia às decisões administrativas; evita concentração excessiva de poderes, despotismos, pri-

10 Programa de Governo do Ministério da Saúde - Gestão do Ministro Adib Jatene, item 02, 1995. Cf. Cit. "Mãos à Obra, Brasil", Proposta de Governo, Fernando Henrique Cardoso, 1995, Conselho Nacional

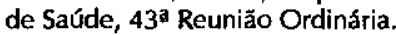


vilégios, apadrinhamentos, omissóes ou transferências de responsabilidades. Evita, também, a prática de um sindicalismo inconseqüente, burocrático, de adesão ou de confronto permanente e insustentável.

Considerando a coincidência de objetivos, as características, a perfeita compatibilidade do SGQ com os princípios que regem a Administração Pública, a adequação do veículo e da forma e a competência legal dos celebrantes, a instituiçăo do Convênio de Gestão Qualificativa apresenta-se como alternativa legal viável, plenamente adequada às diretrizes políticas e administrativas vigentes.

\title{
Referências Bibliográficas
}

CRETELLA Jr, J. Curso de Direito Administrativo. Săo Paulo: Forense, 1992.

MELLO, C. A. B. Curso de Direito Administrativo. São Paulo: Malheiros Editores, 1994.

GASPARINI, D. Direito Administrativo. São Paulo: Saraiva, 1992.

SILVA, J. A. Curso de Direito Constitucional Positivo. São Paulo: Malheiros Editores, 1992.

MEIRELLES, H. L. Direito Administrativo Brasileiro. São Paulo: Malheiros Editores, 1992.

MOTTA, C. P. C. Eficácia nas Licitaçöes e Contratos. Belo Horizonte: Editora Del Rey, 1994.

\subsection{CONTEÚDO PARA CONVÊNIOS EM GERAL: MODELO SUGERIDO}

\author{
Convênio do Sistema de Gestão Qualificativa \\ das Relações de Emprego, de Trabalho e \\ dos Serviços Públicos
}

\section{Constituição} partícipes,

Cláusula Primeira. Por intermédio da celebração do presente Convênio, seus ................, e a entidade órgão da Administração Pública vinculado ao instituem o Sistema de Gestão Qualificativa das Relações de Emprego, de Trabalho e dos Senviços da (SGQ), nos termos ora estabelecidos.

Cláusula Segunda. O SCQ constitui-se em um conjunto de postulados, princípios, regras e procedimentos, capaz de motivar o envolvimento e promover a participação efetiva dos servidores deste órgão e dos usuários dos serviços, em sua realização.

$\S 7^{9}$. O SGQ configura-se como instrumento de auxílio e de apoio à consecução das finalidades administrativas do órgão e de democratização do seu processo gerencial. 
$\S 2^{\circ}$. Entende-se por finalidade administrativa a prestação e $o$ atendimento, com qualidade, eficácia e democracia, dos serviços públicos e das demandas da cidadania, em seu benefício e em benefício da dignidade da pessoa humana.

$\S 3$ ㅇ. O SGQ não se constitui em co-gestão administrativa; não repassa responsabilidades administrativas a terceiros; não impõe limitações ao exercício constitucional da atividade sindical e não restringe a autonomia e a legitimidade de interesses dos partícipes.

\section{Postulados, Objetivos e Metas}

\section{Cláusula Terceira. Constituem postulados do SGQ:}

a) perseguir, a título de objetivos gerais, a consecução das finalidades administrativas do setore, a título de objetivos específicos, o desenvolvimento das suas relações de emprego e de trabalho, o tratamento dos conflitos que insurgem em seu curso e a instituição de mecanismos de controle social sobre o gerenciamento dos senviços;

b) obter melhorias no âmbito da resolutividade, da produtividade, do desempenho, da qualidade e da eficácia profissional dos servidores e dos serviços públicos oferecidos;

c) propugnar pela dignificação, motivação e qualificação profissional dos seus quadros;

d) promover a democratização do processo de tomada de decisões em sua esfera de competência;

e) renovar, modernizar e democratizar procedimentos gerenciais pertinentes à área de recursos humanos;

f) regulamentar, democraticamente, a participação organizada e dirigida dos servidores e dos usuários dos serviços, por intermédio da atuação direta da(s) entidade(s) subscritora(s).

Parágrafo Único. Para alcançar os objetivos gerais e específicos estatuídos neste artigo, os partícipes estabelecem, entre outras, as seguintes metas: (exemplos)
a) ..........(informatização);
b) ...........(concurso público);
c) ..........(treinamento, qualificação e reciclagens);
d) .........(realocação de servidores);
e) ..........(estabelecimento de metas de produtividade);
f) ..........(adoção de sistema conjunto e integrado de avaliação dos serviços).

\section{Princípios}

Cláusula Quarta. O Sistema de Gestão Qualificativa das Relações de Emprego, de Trabalho e dos Serviços reger-se-á pelos seguintes princípios:

a) da legalidade, segundo o qual faz-se necessário o escopo da lei para dar guarida às ações do administrador público; 
b) da moralidade, por meio do qual se exige probidade administrativa;

c) da impessoalidade, finalidade ou indisponibilidade do interesse público, pelos quais o administrador náo pode omitir-se ou emitir providências que contrariem os interesses dos cidadãos usuários e da Administração Pública;

d) da liberdade sindical, que assegura o livre exercício da atividade no setor público e a legalidade e legitimidade de representação e de defesa de interesses dos servidores junto à Administração Pública;

e) da democratização, decorrente da aplicação do princípio participativo no gerenciamento dos serviços públicos e no desenvolvimento das relações de trabalho.

\section{Procedimentos}

Cláusula Quinta. O funcionamento do SCQ observará os seguintes procedimentos, entre outros que poderão ser estabelecidos:

a) instituição do sistema de Mesa de Participação e Negociação Permanente, a ser integrado por ............, representantes da ............., e por ..........., representantes do assim entendido o processo de realização de reuniōes conjuntas, sistemáticas e regradas, conduzidas para apreciação, análise e tratamento de conflitos, e para discussão de assuntos de interesse comum, relacionados ao desenvolvimento das relações de emprego e de trabalho no setor, em benefício da qualidade e eficácia dos serviços;

b) descentralização e combinação deste sistema, considerando-se os diversos níveis de competência e de organização do órgão e das entidades sindicais, assegurando-se, prioritariamente, o seu funcionamento nos locais de trabalho, onde são realizados serviços ao público;

c) direito de obter respostas escritas e arrazoadas, fixação de prazos para os procedimentos, dados, números e informações não confidenciais pertinentes ao objeto do Sistema;

d) prerrogativas e liberdade de pauta para todos os partícipes, observados os objetivos específicos e gerais definidos;

e) formalização e exposição de motivos e de razões das questóes tratadas em pedidos, respostas, réplicas ou tréplicas;

f) registro das discussões e formalização dos resultados por intermédio da assinatura de protocolos.

Cláusula Sexta. Caberá à Mesa de Participação e Negociação Permanente, além de outras atribuições:

a) aprovar o seu regimento interno, definir niveis de competência e formas de representação e de funcionamento, regular, coordenar e adotar as providências necessárias à sua implantação e ao seu funcionamento nos diversos locais de trabalho;

b) dar tratamento aos conflitos insurgentes, segundo postulados, princípios, procedimentos e regras de funcionamento previstas neste convênio, de forma a atender aos objetivos previstos. 
Cláusula Sétima. A aprovação das matérias submetidas ao SCQ dependerá do consenso dos seus partícipes, não se considerando obstativas para esse fim as abstençôes ou ausências de representantes à reunião, desde que regularmente convocados.

Cláusula Oitava. As decisōes decorrentes da aplicação do SGQ, para alcançarem efeitos legais, deverão ser encaminhadas na forma e nas condições previstas na legislação referente à Administração Pública.

Parágrafo Único. Reconhece-se o efeito legal dos protocolos assinados pelo administrador, resultantes de acordos obtidos nas Mesas de Participação e Negociação Permanente.

Cláusula Nona. Nos locais de trabalho, definidos de comum acordo pelos convenientes, fica assegurada a eleição, quando não houver, de um representante sindical para integrar o SGQ.

Parágrafo Único. Ausências de servidores representantes e/ou dirigentes sindicais ao trabalho decorrentes da participação no SGQ serão justificadas. Para todos os fins e efeitos legais, serão consideradas como se em exercício normal de suas atividades funcionais.

Cláusula Décima. A seu critério e dependendo da disposição das entidades convidadas, a Mesa de Participação e Negociação Permanente poderá promover a constituição de Comissão Consultiva de Usuários e Contribuintes, integrada por representantes da sociedade civil organizada, a quem poderá submeter consultas sobre assuntos de interesse comum.

$\S 1$ 10. Existindo comissões de usuários e/ou de contribuintes, estas poderão fazer-se representar nas reuniōes da Mesa, com direito a voz, ficando-lhes assegurada a prerrogativa de requerimento formal sobre assuntos diretamente relacionados aos interesses que representam.

$\S 2$. Os partícipes se comprometem a estimular a criação e a participação de organismos representativos dos usuários dos serviços prestados pela unidade.

Cláusula Décima Primeira. Ao objetivarem o aprimoramento da qualidade, da eficácia e do nível de resolutividade no atendimento às demandas da cidadania, por intermédio da melhoria da qualidade das condições de realização dos serviços públicos, os partícipes declaram-se aptos e desimpedidos para a celebraçăo do presente Convênio, que é firmado, por prazo indeterminado, em vias de igual teor.

\subsection{CONTEÚDOS PARA LEGISLAC̣ÃO}

\section{Proposta para Projeto de Lei Ordinária (de caráter geral)}

Introdução de Sistema de Gestão Qualificativa (SCQ) e Instituição de Conselho Nacional de Administração Pública 


\section{Título I}

\section{Da Instituiçāo do Sistema}

Art. 1․ Os órgãos que integram a Administração Pública, direta e indireta, da União, Estados, Distrito Federal e Municípios, buscarão instituir o presente Sistema de Gestão Qualificativa das Relações de Emprego, de Trabalho e dos Serviços Públicos na forma e nos termos previstos nesta lei.

$\S 10$. A Gestão Qualificativa prevista nesta lei deve constituir-se como instrumento de auxílio e apoio à consecução das finalidades administrativas, e de democratização do seu processo gerencial.

$\S 2^{\circ}$. Entendem-se por finalidade administrativa a prestação e o atendimento, com qualidade, eficácia e democracia, dos serviços públicos e das demandas da cidadania, em seu benefício e em benefício da dignidade da pessoa humana.

Art. 2․ O SGQ constitui-se em um conjunto de postulados, princípios, regras e procedimentos, capaz de motivar o envolvimento e promover a participação efetiva de servidores e de comunidades de usuários dos serviços públicos.

Art. 3․ O SGQ observará a forma de convênio e os procedimentos que nele forem estatuídos, devendo constar, expressamente, dos seus termos, os postulados, princípios e regras, previstos nesta lei.

Parágrafo Único. Poderão ser celebrados convênios para introdução de Sistemas de Gestão Qualificativa entre órgãos da Administração Pública e entidades civis e sindicais em número ilimitado.

Art. 4․ Constituem postulados do SGQ:

a) perseguir, a título de objetivos gerais, a consecução das finalidades administrativas e, a título de objetivos específicos, o desenvolvimento das relações de emprego e de trabalho no setor público, o tratamento dos conflitos que insurgem em seu curso e a instituição de mecanismos de controle social sobre o gerenciamento dos serviços;

b) obter melhorias no âmbito da resolutividade, da produtividade, do desempenho, da qualidade e da eficácia profissional de servidores e serviços públicos;

c) propugnar pela dignificação, motivação e qualificação profissional dos quadros da Administração Pública;

d) promover a democratização do processo de tomada de decisões na esfera administrativa;

e) renovar, modernizar e democratizar procedimentos gerenciais pertinentes à área de recursos humanos;

f) regulamentar, democraticamente, a participação organizada e dirigida dos servidores, por intermédio de suas entidades sindicais e de classe e, também, a participação da comunidade de usuários, por intermédio de entidades civis, no tratamento dos assuntos de interesse comum.

Art. 5․ O SGQ reger-se-á pelos seguintes princípios, entre outros que vierem a ser estabelecidos pelos partícipes:

a) da legalidade, segundo o qual se faz necessário que o escopo da lei dê guarida às ações do administrador público; 
b) da moralidade, por meio do qual se exige probidade administrativa;

c) da impessoalidade, finalidade ou indisponibilidade do interesse público, pelos quais o administrador não pode omitir-se ou tomar providências que contrariem os interesses dos cidadãos usuários e da Administração Pública;

d) da liberdade sindical, em que se asseguram o livre exercício da atividade sindical no setor público e a legalidade e legitimidade de representação e de defesa de interesses dos servidores junto à Administração Pública;

e) da democratização, resultado da aplicação do princípio participativo no gerenciamento dos serviços públicos e no desenvolvimento das relaçōes de trabalho.

Art. $6^{\circ}$. São condições para a configuração do SCQ a participação formal e efetiva de entidades sindicais e de classe, legalmente representativas dos interesses dos servidores públicos e a observância às seguintes regras e mecanismos de funcionamento:

a) instituição do sistema de Mesa de Participação e Negociação Permanente, assim entendido o processo de realizaçáo de reunióes conjuntas, sistemáticas e regradas, conduzidas para apreciação, análise e tratamento de conflitos, e para a discussão de assuntos de interesse comum, notadamente relacionados ao desenvolvimento das relaçōes de emprego e de trabalho no setor, em benefício da qualidade e da eficácia dos serviços, integradas por representantes da Administração Pública e das entidades sindicais e de classe dos servidores;

b) descentralização e combinação deste sistema, considerando-se os diversos níveis de competência e de organização da Administração Pública e das entidades sindicais, assegurando-se, prioritariamente, o seu funcionamento nos locais de trabaIho, onde são realizados serviços ao público;

c) direito de obter respostas escritas e arrazoadas, dados e informaçōes não confidenciais pertinentes ao objeto do Sistema;

d) registro das discussões e formalização dos resultados por meio da assinatura de protocolos.

Parágrafo Único. As regras e os mecanismos de funcionamento estabelecidos neste artigo, assim como o que mais os partícipes vierem a instituir serão regulamentados por meio do convênio específico a ser celebrado.

Art. 7‥ A seu critério e dependendo da aceitação das entidades convidadas, os partícipes do Sistema poderão promover a constituição de Comissão Consultiva de Usuários e Contribuintes, integrada por representantes de entidades da sociedade civil, a quem poderão submeter consultas sistemáticas sobre assuntos de interesse comum, nos termos previstos nos respectivos convênios.

Parágrafo Único. Os partícipes do Sistema envidarão esforços para estimular a criaçăo e a participação de organismos representativos da comunidade de usuários dos serviços prestados em cada unidade de serviço.

Art. $8^{\mathrm{q}}$. A aprovação das matérias submetidas ao SGQ dependerá da posição consensual dos seus partícipes, não se considerando obstativas para esse fim as abstenções ou ausências de representantes à reunião, desde que regularmente convocados. 
Art. 9o. Para alcançarem efeitos legais, as decisões decorrentes da aplicação do SGQ. deverão ser encaminhadas na forma e nas condições previstas na legislação referente à Administração Pública.

Parágrafo Único. Atribui-se efeito legal aos protocolos assinados pelo administrador, resultantes de acordos obtidos nas Mesas de Participação e Negociação Permanente, quando não houver impedimento legal para a adoção deste procedimento.

Art. $10^{\circ}$. As entidades sindicais representativas dos servidores públicos, legalmente constituídas para este fim, poderăo solicitar, junto ao órgão administrativo competente, a celebração de convênio objetivando os fins previstos nesta lei.

Parágrafo Único. A negativa por parte de determinado agente administrativo em celebrar convênios nos temos previstos nesta lei ensejará apreciação e posterior recomendação ou determinação do Conselho Nacional de Administração Pública, desde que sua manifestação seja requerida por qualquer dos postulantes.

Art. $11^{\circ}$. Nos locais de trabalho, definidos de comum acordo pelos convenientes, fica assegurada a eleiçăo, quando não houver, de um representante sindical para integrar o Sistema de Gestão Qualificativa.

Parágrafo Único. As ausências ao trabalho, decorrentes da participação no SGQ, de servidores representantes e dirigentes sindicais, serão consideradas justificadas, considerando-os como se estivessem em exercício normal de suas atividades funcionais, para todos os fins e efeitos legais.

Art. $12^{\circ}$. A adoçáo do SGQ previsto nesta lei deve constituir prioridade entre as iniciativas modernizadoras do serviço público, e sua aplicaçăo deve ser considerada de relevante interesse para a Administração Pública.

\section{Título II \\ Do Conselho Nacional de Administração Pública}

Art. $13^{\circ}$. Fica instituído, nos termos desta lei, o Conselho Nacional de Administração Pública (CONAP), a ser integrado por representantes dos seguintes poderes, órgãos, entidades e segmentos sociais:

a) Poder Executivo: um representante indicado pelo Presidente da República;

b) Poder Legislativo: um representante indicado pela Presidência do Congresso Nacional;

c) Poder Judiciário: um representante indicado pelo Presidente do Supremo Tribunal Federal;

d) Ministério Público Federal: um representante indicado pela Procuradoria Geral da União;

e) dois representantes do funcionalismo público, indicados por entidades sindicais do setor, escolhidas em eleições diretas pelos servidores.

f) um representante indicado pelo Presidente do Tribunal de Contas da União (TCU). 
h) representando os interesses dos usuários dos senviços públicos:

1. um representante indicado pela Ordem dos Advogados do Brasil (OAB) e outro pela Associação Brasileira de Imprensa (ABI);

II. um representante indicado por órgão público de defesa dos direitos do consumidor (PROCON);

III. um representante dos interesses dos cidadãos aposentados, indicado por entidade legal, que goze de legitimidade em âmbito nacional.

IV. dois representantes dos trabalhadores assalariados, indicados por intermédio de suas centrais sindicais;

V. um representante indicado pela Confederação Nacional da Indústria (CNI).

\$ $7^{\circ}$. Aos representantes, trabalhadores assalariados, membros do Conselho, titulares e suplentes será assegurada a estabilidade no emprego, desde a data da indicação até um ano após o término do mandato de representação, salvo dispensa por cometimento de falta grave, devidamente comprovada em processo judicial.

$\S 2$. As ausências ao trabalho decorrentes das atividades de representação no CONAP, de servidores e demais assalariados serão justificadas; considerando-se como se estivessem em exercício normal de suas atividades funcionais, para todos os fins e efeitos legais.

Art. 14ㅇ. São atribuições do CONAP, entre outras que vier a estabelecer:

a) elaborar seu regimento interno;

b) elaborar estatutos e planos de cargos, carreiras e salários dos servidores públicos e encaminhar para aprovação das instâncias competentes.

c) estabelecer normas e parâmetros administrativos para o exercício do direito de greve nas atividades essenciais do setor público;

d) estabelecer parâmetros, orientar e zelar pela aplicação do SGQ, determinando, quando for o caso e se tratar de órgão público federal, sua instituiçăo, nos termos previstos nesta lei;

e) aprovar o Manual de Normas e Procedimentos de Concursos Públicos para a União, Estados e Municípios;

f) constituir comissão paritária para acompanhar e agilizar processos de exoneração de servidores por cometimento de falta grave;

g) realizar estudos e propor adequações na organização, redistribuição e remanejamentos de servidores;

h) encaminhar projetos de lej ao Congresso Nacional, versando sobre temas referentes à Administração Pública e/ou aos seus servidores.

Art. $15^{\circ}$. As deliberaçóes do Conselho somente poderão ser conduzidas com a presença mínima de dois terços dos conselheiros.

$\S 10$. Considerar-se-á aprovada a matéria que receber votação favorável de dois terços dos membros do Conselho presentes à reunião.

§ 2o. As decisões do CONAP serão adotadas sob a forma de 'Resolução' e passarão a vigir após publicação no Diário Oficial da União, determinada pelo Ministro da Administração e Reforma do Estado. 
Art. 16‥ O mandato dos membros do Consetho, representantes da sociedade civil, servidores públicos e usuários será de três anos, permitida uma recondução.

Art. 170. Os órgãos e entidades integrantes do CONAP indicarão igual número de suplentes para substituírem os representantes efetivos em seus impedimentos.

Art. 18․ Presidirá a instalação e o primeiro período de funcionamento do CONAP o Ministro da Administraçăo e Reforma do Estado, cabendo ao Conselho definir, em seu Regimento Interno, sua estrutura e forma de funcionamento.

Art. 19. Revogam-se as disposições em contrário.

\section{Proposta de Legislação Ordinária de Suporte para a Saúde}

Sistema de Gestão Qualificativa das Relações de Emprego, de Trabalho e dos Serviços do Sistema Único de Saúde

Art. 19. Os órgãos da Administração Pública Federal, Estadual, Municipal e do Distrito Federal, integrantes do SUS, buscarāo instituir o presente Sistema de Gestão Qualificativa das Relaçōes de Emprego, de Trabalho e dos Serviços do Sistema Único de Saúde, SGQ-SUS, na forma e nos termos previstos nesta lei.

$\S 7 \%$. O SGQ-SUS deve constituir-se como instrumento de auxílio e de apoio para atingir as finalidades administrativas específicas da área e de democratização do seu gerenciamento.

$\S 2^{o}$. Entendem-se por finalidade administrativa específica da área a prestação e o atendimento, com qualidade, eficácia e democracia, dos serviços e das demandas da cidadania por saúde pública, em seu benefício e da dignidade da pessoa humana.

Art. 2ㅇ. O SGQ constitui um conjunto de postulados, princípios, regras e procedimentos capaz de motivar o envolvimento e promover a participação efetiva dos servidores públicos e de comunidades de usuários dos serviços de saúde.

Art. 3․ O SCQ-SUS observará a forma de convênio e os procedimentos nele estatuídos, devendo constar, expressamente, dos seus termos, os postulados, princípios e regras previstos nesta lei.

Parágrafo Único. Poderão ser celebrados convênios para introdução de SCQs, entre órgãos da Administração Pública direta e indireta integrantes do SUS e entidades civis e sindicais, em número ilimitado.

Art. 4․ Constituem postulados do SCQ:

a) buscar, a título de objetivos gerais, a consecução das finalidades administrativas do setor e, a título de objetivos específicos, o desenvolvimento das relaçōes de emprego e de trabalho, o tratamento dos conflitos surgidos em seu curso e a instituição de mecanismos de controle social sobre o gerenciamento dos serviços;

b) obter melhorias no âmbito da resolutividade, da produtividade, do desempenho, da qualidade e da eficácia profissional dos servidores e dos serviços públicos da área da saúde;

c) propugnar pela dignificação, motivação e qualificação profissional dos quadros da Administração Pública integrante do SUS; 
d) promover a democratização do processo de tomada de decisōes na esfera administrativa;

e) renovar, modernizar e democratizar procedimentos gerenciais pertinentes à área de recursos humanos;

f) regulamentar, democraticamente, a participação organizada e dirigida dos servidores, por intermédio de suas entidades sindicais e/ou de classe e, também, a participação da comunidade de usuários, por intermédio de entidades civis, no tratamento dos assuntos de interesse comum.

Art. 50. O SGQ reger-se-á pelos seguintes princípios, entre outros que vierem a ser estabelecidos pelos partícipes:

a) da legalidade, segundo o qual se faz necessário que o escopo da lei dê guarida às ações do administrador público;

b) da moralidade, por meio do qual se exige probidade administrativa;

c) da impessoalidade, finalidade ou indisponibilidade do interesse público, pelos quais o administrador não pode omitir-se ou tomar providências que contrariem os interesses dos cidadãos usuários e da Administração Pública;

d) da liberdade sindical, em que se asseguram o livre exercício da atividade sindical no setor público e a legalidade e legitimidade de representação e de defesa de interesses dos servidores junto à Administração Pública;

e) da democratização, resultado da aplicação do princípio participativo no gerenciamento dos serviços públicos e no desenvolvimento das relações de trabalho.

Art. 6․ São condições para a configuração do SGQ a participação formal e efetiva de entidades sindicais e/ou de classe, legalmente representativas dos interesses dos senvidores públicos e a observância às seguintes regras e mecanismos de funcionamento:

a) instituição do Sistema de Mesa de Participação e Negociação Permanente, assim entendido o processo de realização de reuniōes conjuntas, sistemáticas e regradas, conduzidas para apreciação, análise e tratamento de conflitos, e para a discussão de assuntos de interesse comum, relacionados aos desenvolvimento das relaçōes de emprego e de trabalho no setor, em benefício da qualidade e da eficácia dos serviços, integradas por representantes da Administração Pública Previdenciária e das entidades sindicais e/ou de classe dos seus servidores;

b) descentralização e combinação deste sistema, considerando-se os diversos niveis de competência e de organização do SUS e das entidades sindicais, assegurando-se, prioritariamente, o seu funcionamento nos locais de trabalho, onde são realizados serviços ao público;

c) direito de obter respostas escritas e arrazoadas, dados, números e informaçóes não confidenciais pertinentes ao objeto do Sistema;

d) registro das discussões e formalização dos resultados por intermédio da assinatura de protocolos.

Parágrafo Único. As regras e mecanismos de funcionamento estabelecidos neste artigo, e outras mais que os partícipes vierem a instituir, serão regulamentadas por meio dos convênios específicos a serem celebrados. 
Art. 7ํ. A seu critério e dependendo da aceitação das entidades convidadas, os partícipes do Sistema poderão promover a constituição de Comissões Consultivas de Usuários e Contribuintes, integradas por representantes de entidades da sociedade civil, a quem poderão submeter consultas sistemáticas, nos termos previstos nos respectivos convênios, sobre assuntos de interesse comum.

Parágrafo Único. Os partícipes do Sistema envidarão esforços para estimular a criação e a participação de organismos representativos da comunidade de usuários dos serviços prestados em cada unidade de serviço.

Art. 8․ A aprovaçăo das matérias submetidas ao SGQ dependerá da posiçăo consensual dos seus partícipes, não se considerando obstativas para esse fim as abstenções ou ausências de representantes à reunião, desde que regularmente convocados.

Art. $9^{\circ}$. As decisões decorrentes da aplicação do SCQ, para alcançarem efeitos legais, deverão ser encaminhadas na forma e nas condições previstas na legislação referente à Administração Pública.

Parágrafo Único. Atribui-se efeito legal aos protocolos assinados pelo administrador, resultantes de acordos obtidos nas Mesas de Participação e Negociação Permanente, quando não houver impedimento legal para a adoçăo deste procedimento.

Art. $10^{\circ}$. As entidades sindicais representativas dos servidores públicos, legalmente constituídas para este fim, poderão solicitar, junto ao órgão administrativo competente, a celebração de convênio objetivando os fins previstos nesta lei.

Parágrafo Único. A negativa por parte de determinado agente administrativo em celebrar convênios nos termos previstos nesta lei, ensejará apreciaçăo e posterior determinação ou recomendação do Conselho Nacional de Saúde, desde que sua manifestação seja requerida por qualquer dos postulantes.

Art. 17․ Nos locais de trabalho, definidos de comum acordo pelos convenientes, fica assegurada a eleiçăo, quando não houver, de um representante sindical para integrar o SGQ.

Parágrafo Único. As ausências ao trabalho, decorrentes da participação no SCQ, de servidores representantes e/ou dirigentes sindicais, serão consideradas justificadas, considerando-os como se em exercício normal de suas atividades funcionais estivessem, para todos os fins e efeitos legais.

Art. $12^{\circ}$. A adoção do SGQ previsto nesta lei deve constituir prioridade entre as iniciativas modernizadoras do serviço público e sua aplicação deve ser considerada de relevante interesse para a Administração Pública.

Art. 13․ Caberá ao Conselho Nacional de Saúde estabelecer parâmetros, orientar e zelar pela aplicação do Sistema de Gestão Qualificativa das Relações de Emprego, de Trabalho e dos Serviços do SUS, recomendando ou determinando, quando for o caso, a sua instituição, nos termos previstos nesta lei.

Art. 14․ Revogam-se as disposições em contrário. 


\section{Roteiro em Seis Passos para IMPLANTANÇÃo de SISTEMAS DE GESTÃo}

O Núcleo Técnico Multiprofissional para a Qualificação de Recursos Humanos constatou que setores interessados em implementar projetos de gestão encontram dificuldades consideráveis para desenvolver conceitos novos e colocar em prática processos semelhantes àqueles com os quais se ocupou. Por este motivo, sugeriu a elaboração de uma espécie de manual prático para introdução desses sistemas em que se aproveitassem ao máximo as experiências conhecidas e estudadas.

Essa orientação resultou na elaboração do Roteiro em Seis Passos para Implantação de Sistemas de Gestão, desenvolvido com base nas experiências vivenciadas pelo autor e estudadas neste trabalho.

$\mathrm{Na}$ metodologia empregada na confecção do roteiro, buscou-se combinar a seqüência de etapas (passo a passo) com a reprodução de conteúdos já aplicados em experiências anteriores. Utilizam-se, para isto, exemplos concretos. Assim, além de orientar a implantação de projetos, busca-se proporcionar aos interessados um panorama dinâmico e melhor visualização do funcionamento desses sistemas. Cumpre, pois, a função de conduzir o leitor ao contato direto com os modelos de gestão já empregados em seus aspectos técnicos e formais. Deste modo, será possível acompanhar mais adequadamente os conteúdos analíticos apresentados no terceiro capítulo e dar maior efetividade aos dois principais objetivos deste trabalho: sistematizar e democratizar experiências na área de qualificação de serviços prestados, assim como contribuir para a implantação de projetos deste tipo.

Contribuirá em muito para o êxito da aplicação do Roteiro observar as seguintes condiçōes prévias:

- que o modelo a ser construído conte com a co-participação dos diversos atores desde o início da sua confecção;

- que o processo seja precedido de diagnóstico para possibilitar conhecimento científico da realidade na qual se deseja intervir;

- que as partes fixem objetivos iniciais claros e precisos; 
- que sejam identificados, desde logo, os diversos campos de interesse e de conflitos;

- que sejam definidas as unidades para introdução setorizada e combinada desses instrumentos.

Feitos os esclarecimento iniciais, as etapas que constituem o roteiro serão desenvolvidas a seguir.

\subsection{DIAGNÓSTICO E DEFINIÇÃO DE PREMISSAS PARA INTRODUÇÃO DE MUDANÇAS}

\section{Diagnóstico: o consenso da insatisfação}

Para desenvolver reflexões, propostas ou projetos de mudanças profundas no setor público, torna-se oportuno compartilhar certas inquietações de ordem prática, sempre presentes em discussóes e estudos realizados sobre o assunto e que podem ser sintetizadas nas seguintes indagações:

- Alguém está satisfeito com a administração dos serviços públicos no Brasil?

- Estariam os administradores públicos satisfeitos com os resultados obtidos por suas administraçōes?

- E os servidores? Estão satisfeitos com o que realizam e com as condições salariais e de trabalho?

- Os usuários estão sendo atendidos em suas demandas? Estão satisfeitos com os serviços pelos quais pagam para receber?

Salvo raras exceções, a insatisfação é a regra geral dos diversos segmentos envolvidos com a administração dos serviços públicos no Brasil. Assim, o primeiro consenso obtido nesta verificação preliminar é negativo. É o consenso do não.

Neste caso, caberia perguntar: legisladores e doutrinadores que formulam determinada legislação e sustentam determinado modelo administrativo cujos resultados deixam a todos insatisfeitos podem estar satisfeitos?

O bom senso indica um não, novamente.

Se ninguém está satisfeito, não será possível mudar algo?

Em áreas sociais, como Saúde, Educação e Previdência Social, caso a resposta a esta última indagação venha a ser novamente não, então estaremos muito mais próximos do fim da inserção do Estado na defesa dos interesses essenciais da cidadania do que se imagina.

As questões pertinentes aos campos das necessidades vitais e da inteligência humana se sobrepōem, no geral, a outras ditas de princípio. Com os custos elevados desses sistemas, a sociedade que os financia não os defenderá apenas por questão de princípios, mas sim, e principalmente, por questão de eficácia.

Em conseqüência, se esta situação permanecer, os únicos interessados que defenderão estes setores serão, por motivos óbvios, seus servidores. 
Pressupondo, pois, que haja acordo quanto à necessidade de se inverter o consenso do não, o próximo desafio seria saber o que, precisamente, se desejaria mudar e o que fazer para alavancar as mudanças.

\section{Definição de Premissas}

Desde o início é preciso ter clareza e acordo sobre finalidades e objetivos a serem atingidos pela Administração Pública. Estas metas não podem estar dissociadas dos interesses maiores da população. As reflexōes feitas pela sociedade brasileira hoje impõem o desafio de repensar o caráter do Estado e suas formas de gerenciamento.

Isto para assegurar-lhes os papéis de provedores de regras e medidas que garantam o exercício dos direitos elementares da cidadania. Assim, inaugura-se a lista das premissas a serem estabelecidas para implantar projetos como este, a fixação do objetivo maior: a plena satisfação às demandas da cidadania.

Existindo, portanto, acordo sobre entendimento - simplificado -, ético e legal dos papéis do Estado e da Administração Pública e considerando-se que se perdeu a consciência de tais objetivos, a primeira mudança fundamental seria instituir instrumentos para resgatar, junto aos interessados, esta noção de finalidade.

A instituição de instrumentos desse tipo contribuiria para desenvolver nova mentalidade. $E$, conseqüentemente, para adotar novas concepções de realização dos serviços públicos, em que se buscaria preservar os interesses da cidadania - aqui entendida como o conjunto da sociedade, especialmente quando em conflito com outros segmentos.

Trata-se, pois, de reverter a situação atual, em que os interesses-meio ou periféricos se sobrepóem aos interesses-fim da administração pública. $O$ núcleo dessa premissa seria: resgatar a noção de finalidade.

Percebe-se, claramente, que executar projetos deste tipo pressupõe mudanças comportamentais e depende de alterações em posturas culturais fortemente arraigadas em nosso meio.

Para modificar algum aspecto cultural, é preciso desenvolver ações no campo subjetivo dos diversos atores, proporcionando, por intermédio de processo de conscientização, de envolvimento e de participação, as condiçōes para alterar comportamentos. Quando se busca responder a indagaçōes do tipo 'como provocar mudanças', três procedimentos conjuntos compõem a premissa: educaçăo, envolvimento e participaçăo direta.

Ao lado dos aspectos volitivos - dependem exclusivamente da vontade das partes - de evidente caráter subjetivo, há também aspectos objetivos, essenciais, envolvidos em mudanças dessa natureza. São condições dadas ou estabelecidas que condicionam ou impedem a implantação de um projeto. Tais preocupaçōes podem ser representadas por meio da premissa: condições objetivas.

Há, contudo, um terceiro aspecto envolvido que transita entre a subjetividade dos atores e a objetividade das condições. Trata-se da criação de instrumentos de ação administrativa. Neste caso, deverão ser de caráter participante, jurídica e doutrinariamente sustentáveis e que possam funcionar de forma complementar ou alternativa aos procedimentos já aplicados. Aqui as premissas são: criatividade e legalidade dos instrumentos. 
A síntese desta reflexão, com as premissas desenvolvidas, até o momento, assume a seguinte forma:

A plena satisfação às demandas da cidadania constitui o objetivo primordial. Para atingi-lo, é necessário resgatar a noção de finalidade da Administração Pública, junto aos seus atores. Este resgate deve ser operado utilizando-se processos de educação, de envolvimento e de participação direta dos interessados. Tais processos dependem de condiçōes objetivas a serem verificadas, da criatividade dos agentes e da legalidade dos instrumentos a serem introduzidos.

\subsection{DEFINIC̣ÃO DE ATORES E SEUS PAPÉIS}

Considerando as premissas estabelecidas, torna-se necessário definir os atores que interagem nesse processo. São três os protagonistas: usuários, servidores e administradores públicos.

Os coadjuvantes poderiam ser vários, destacando-se, como principais, os Poderes Legislativo e Judiciário.

Qual será, efetivamente, o grau de vontade de que dispõem esses atores para perpetrar mudanças? Entende-se que, se não houver clara vontade política de pelo menos dois desses protagonistas - administradores e servidores públicos - não será possível iniciar qualquer processo de mudança profundo na Administração Pública, questão que será tratada mais à frente.

\subsection{PROVIDÊNCIAS PRELIMINARES}

constituição de grupo de trabalho e coordenação técnica do projeto, definição orçamentária e infra-estrutura básica para sua implantação, promoção de atividades e aglutinação de núcleos e entidades interessadas, pesquisas e estudos de experiências desenvolvidas sobre $o$ assunto

As iniciativas sugeridas no terceiro passo do Roteiro têm caráter técnico e não apresentam maiores dificuldades conceituais para implementaçăo e execução. Porém, nas experiências estudadas, os graus de organização, convencimento e convergência em torno das linhas gerais dos modelos adotados somente puderam ser alcançados depois de amadurecidas as idéias. Para isto, necessitou-se de inúmeros debates, reuniões, seminários, estudos etc., razão pela qual estes tópicos não podem ser menosprezados.

Há contribuições a essas etapas no conjunto deste trabalho. Veja-se a proposta de Coordenação de Relações de Trabalho, a sugestão de estrutura necessária para a consecução das suas atribuiçóes e o roteiro para implantação do Sistema Permanente de Negociação Coletiva de Trabalho na Prefeitura do Município de São Paulo, apresentados nos estudos Política de Pessoal na Administração Pública (capítulo 3). A celebração do protocolo prévio de intenções naquela administração municipal foi precedida de seminário internacional sobre o tema. Mencione-se, ainda, que o protocolo de 
intenções firmado no âmbito do INSS/SP (comentado no capítulo 3 e reproduzido a seguir) foi celebrado ao final de um ciclo de estudos e debates, durante a realização de seminário em defesa da qualidade dos serviços e da previdência social pública.

\subsection{CONFIGURAÇÃO DO SISTEMA}

caracterização e formulação das linhas gerais do sistema: aferição do grau de disposição politica dos interlocutores para implantação do projeto - protocolos prévios de intençōes

Formando-se um grupo técnico ou coordenadoria dos trabalhos, a realizaçăo de reuniōes entre as partes, a sistematização de estudos e a promoção de atividades envolvendo órgãos, entidades e setores interessados, a continuidade do processo de implantação do projeto passa a exigir a definição expressa das linhas básicas do modelo que se pretende introduzir.

É necessário, portanto, que os termos desse modelo sejam redigidos conjuntamente e apresentados em um documento-base. A redação conjunta exigirá negociação e proporcionará uma primeira aferição do grau de convergência entre os partícipes e a sua disposição real em envolver-se com o projeto.

Ultrapassadas as etapas preliminares, o entendimento mínimo sobre o que se deseja será demonstrado com a redação conjunta de documento específico. Esse processo, geralmente, é submetido à ratificação de instâncias superiores - as assembléias dos servidores, no caso de sindicatos; e dos superiores hierárquicos, no caso dos administradores, por exemplo.

Obtidas as aprovações necessárias, o documento ganha a forma de protocolo prévio de compromisso ou de intençōes e será assinado pelos participantes, podendo receber adesões posteriores. Por isso, celebrar protocolos desse tipo é, ao mesmo tempo, documento básico de configuração do processo e procedimento para a mediçâo do grau de seriedade e compromisso das partes para com o projeto.

Há experiências em que se dispensou a celebração de protocolos prévios de compromisso e se passou, diretamente, das discussōes preliminares à celebração dos instrumentos reguladores $\mathrm{e}$ formalizadores do sistema, como no IAMSPE.

É no curso desses processos iniciais que ocorrem os principais entraves à viabilização dos projetos. São representados, muitas vezes, por pareceres e análises técnicas, especialmente de caráter jurídico, contrários à sua instituição. É preciso, então, fundamentá-los teórica e doutrinariamente para ganharem sustentaçăo consistente. Além disso, torna-se necessário tomar precauçōes para que o modelo escolhido não contrarie a legislação vigente.

Para conhecer como foi tratado o assunto nas experiências aqui comentadas serão transcritos, a seguir, dois protocolos prévios de intenções. O primeiro foi firmado em 1990, no âmbito da Prefeitura Municipal de São Paulo, o outro em 1994, no âmbito do Instituto Nacional de Seguro Social (INSS), do Ministério da Previdência e Assistência Social no Estado de São Paulo. 
Administrar conflitos do trabalho significa dispor de um sistema baseado na transparência, constituído de forma permanente, com regras precisas, articulado e dinâmico, que goze da absoluta credibilidade junto às partes, as quais devem integrá-lo desde a sua formulação.

\section{Princípios Fundamentais do Sistema}

a) da indisponibilidade do interesse público;

b) da liberdade de organização, de exercício da atividade sindical, do direito de greve e do afastamento de dirigentes sindicais para o exercício do mandato sindical;

c) da legitimidade de representaçăo e do respeito à vontade soberana da maioria dos representados, com a adoção de procedimentos democráticos de deliberação, previstos nos estatutos das entidades sindicais subscritoras;

d) da prerrogativa das partes em celebrarem instrumentos coletivos de trabalho;

e) da publicidade e formalização dos atos e dos procedimentos administrativos;

f) do direito de acesso à informação;

g) do caráter permanente e articulado do sistema e da obrigatoriedade das partes em negociarem quando solicitado por uma delas;

h) da legalidade, da eficácia jurídica e do poder normativo dos instrumentos celebrados;

i) da independência do movimento sindical e da autonomia das partes, năo configurando o processo de co-gestão.

\section{Implantação do Projeto}

Para viabilizar a implantação do sistema negocial geral do funcionalismo, as partes se comprometem a manter a continuidade das discussōes, no sentido de se estabelecer o seu funcionamento, instalando-se, para tanto, uma mesa de negociação com representação paritária, considerando cada entidade subscritora.

\section{Objeto da Negociação}

a) formulação e assinatura de acordo implantando Sistema Permanente de Negociação Coletiva de Trabalho;

b) envio de projeto de lei ao Legislativo, institucionalizando o processo de negociação e contratação coletiva de trabalho;

c) regime jurídico único;

d) quadro de pessoal e plano de carreira;

e) fixação e correção salarial - critérios e aplicação;

e) data-base. 
A ação interativa dos diversos interlocutores sociais, coadunando interesses específicos à consecução dos objetivos fins da instituiçăo pública, pode viabilizar a eficiente prestação de serviços essenciais à população de São Paulo, razão pela qual firma-se o presente protocolo.

\section{Segundo exemplo}

Um Compromisso em Defesa da Previdência Pública e da Qualidade dos Serviços Previdenciários ${ }^{2}$

\section{Objetivos Gerais}

O presente Protocolo busca estabelecer objetivos comuns a serem priorizados pelas partes, fixar princípios que deverão nortear sua consecução e apontar caminhos para $o$ tratamento democrático de conflitos que se interpõem na realização dos serviços.

Funda-se no conceito de que ao Estado compete, dentre outras obrigaçóes, promover e assegurar o exercício pleno da cidadania. O Brasil, como Estado Democrático de Direito, tem como fundamentos básicos, entre outros, a "cidadania" e os "valores sociais do trabalho e da livre iniciativa" (artigo 10 da Constituição da República).

Ao Estado, como objetivo maior da sua intervenção no campo social, onde a cidadania pressupõe a efetivação de direitos, cabe adquirir capacidade para:

- com os diversos segmentos da sociedade, formular alternativas e propostas concretas de políticas sociais, voltadas ao essencial exercício da cidadania;

- arrecadar os recursos necessários a sua viabilização;

- executar serviços de qualidade, atendendo às demandas da sociedade, em suas necessidades básicas, entre as quais figuram o direito à vida, ao trabalho, à educação, à saúde e à Previdência Social.

\section{Objetivos Específicos}

Sob esta formulação, a qualidade dos serviços previdenciários compreende a arrecadação, a fiscalização das contribuições, a concessão de benefícios e o atendimento aos usuários, quer na condição de contribuintes, quer na de beneficiários do sistema.

2 Este protocolo foi celebrado durante seminário realizado na cidade de São Paulo, em 13/04/94. As entidades signatárias estiveram assim representadas: Superintendência Estadual do INSS/SP: Milton Molinari Morete, Sindicato dos Fiscais de Contribuiçóes Previdenciárias de São Paulo (SINDIFISP/SP): Carmelina Calabrese Nunes, Coordenação de Arrccadação e Fiscalização (CAF/INSS/SP): Ayda Tereza Sonnesen Losso. 
Aos olhos da sociedade, o balcão de benefícios previdenciários se confunde com a própria Previdência Social. É ali que o cidadão se depara com atendimento muitas vezes precário e recebe benefícios cujos valores, talvez, não satisfaçam suas necessidades básicas. Este é o cartão de visitas da Previdência Social.

lludem-se, contudo, aqueles que, não trabalhando diretamente na área, acreditam não ter qualquer tipo de responsabilidade diante do descontentamento crônico da sociedade, traduzido no cansaço da populaçăo com o descaso das autoridades, nos constantes ataques da mídia e na pressão de poderosos grupos econômicos, contrários à manutenção da previdência social pública.

As conseqüências de tal descontentamento atingirão a instituição como um todo: administradores, servidores administrativos, fiscais, procuradores etc.

Daí não ser difícil concluir que a melhor defesa da previdência pública é aquela que preconiza a qualidade e a eficácia dos serviços, de forma a atender às demandas de sociedade.

A aliança com os interesses da cidadania e da sociedade é a única maneira de eliminarmos, em definitivo, as ameaças de privatização da Previdência Social.

\section{Noçōes de Finalidade e Globalidade}

Percebe-se, pois, consensualmente, que o objetivo-fim da Administração Pública deve ser estabelecido em torno dos interesses e do atendimento às demandas da sociedade, de forma a dar sustentação às necessidades essenciais ao exercício da cidadania.

Qualidade, eficácia e produtividade do trabalho são condições básicas à consecução destes objetivos.

Abandonar a cultura que em salários aviltados e servidores desmotivados revezam-se como justificativas do quadro de deterioração dos serviços prestados, retomando a noção de finalidade é ato volitivo, devendo ser compromisso de todos e de cada um, administrador ou funcionário, empenhados em cumprir sua cota de responsabilidade na efetivação desta tarefa.

Complementarmente, é dever de consciência, obrigação funcional e direito de cada servidor visualizar o necessário grau de inter-relacionamento entre os diversos setores da administração, cada um dos quais participa na consecução dos objetivos gerais da Previdência Social.

Alterar posturas culturais, de forma eficiente e em prazos compativeis com nossas necessidades, depende ainda de informação, conscientização e convencimento, a serem iniciados por aqueles que detêm algum tipo de influência e/ou autoridade sobre o conjunto dos atores envolvidos na Administração Pública.

Conjuntamente, tais premissas permitem corrigir os desvios de rota, melhorar a produção e a qualidade dos serviços e impedir que interesses periféricos se sobreponham ao interesse-fim da administração previdenciária. 


\section{O Imediato e o Específico}

O aprimoramento da máquina administrativa é condição básica para o cumprimento dos objetivos traçados. Implica a adoção de medidas de curto, médio e longo prazos, de caráter objetivo, como investimentos consistentes nas áreas de Recursos Humanos, contratação de funcionários, remuneração digna, qualificação profissional, empenho e produtividade dos servidores, bem como investimentos nas áreas de equipamentos, de informática e condiçōes materiais e físicas para a realização do trabalho.

Paralelamente, sabemos que problemas de diversas naturezas interferem na realização dos trabalhos de arrecadação e fiscalização das contribuições previdenciária. São conflitos e 'gargalos' que surgem no dia-a-dia. Têm causas e conseqüências diversas e, quando não geram problemas maiores, servem para minar a capacidade de trabalho, irritar e desmotivar os servidores, interferindo na qualidade e na produtividade dos senviços.

São comuns, por exemplo, conflitos decorrentes de relacionamento hierárquico, de conduta profissional, de desentendimento entre categorias funcionais, de interpretação de normas, de alterações de procedimentos, de fixação de prioridades, entre outros. Insegurança e incertezas decorrentes da descontinuidade administrativa contribuem bastante para a desmotivação e o descompromisso com objetivos, metas e prioridades.

Questões como a sonegação das contribuições sociais, corrupção funcional, novas fontes de custeio e equilíbrio financeiro, deveriam ser objeto de permanente reflexão e discussão, não só da Administração, como também dos servidores da Previdência Social.

Igualmente, não dispomos de canais que possam ser utilizados de forma sistemática no diagnóstico de problemas, que sirvam à analise das dificuldades detectadas, que permitam, partindo do específico para o geral, de baixo para cima, estabelecer visões globais e detalhadas.

Não dispomos de canais institucionais que, possibilitando a atuação conjunta de todos, viabilizem a apresentação e discussão de propostas de soluções, mudanças e aprimoramentos.

\section{Conclusōes}

Assim sendo, no âmbito específico das atribuições da CAF/SP e de representação do SINDIFISP/SP, de forma a permitir, estimular e manter permanentemente a participação dos fiscais em relação aos tópicos de caráter geral, mas, sobretudo, para instituir, de maneira concreta, objetiva, específica e imediata, canais de administração dos conflitos que interferem na qualidade, produtividade, motivação e condições de trabalho, as partes - com total apoio da administração superior e respaldo da categoria, a título de encerramento de uma primeira etapa do processo de reflexão que estabeleceram - consideram ser possível registrar as seguintes conclusōes e encaminhamentos, para viabilização de aplicabilidade da proposta de gestão participativa, que vêm discutindo: 
- Formulação de um conjunto de princípios e de regras de funcionamento que permitam tratar, de forma permanente e democrática, todo e qualquer conflito que interfira na qualidade, eficácia e produtividade dos serviços.

Dentre aqueles que nortearão a formulação do sistema, são fundamentais os princípios da transparência administrativa, do acesso à informação, da formalização e fundamentação das questões tratadas, da formalização dos resultados, da prerrogativa de ambas as partes pautarem as discussōes, da fixação de prazos, do direito de resposta por escrito, da indisponibilidade do interesse público, da autonomia e da legitimidade das partes defenderem seus interesses específicos, não se confundindo com processo de co-gestão administrativa, da legalidade e do direito de organização e de exercício da atividade sindical, dentre outros que estabelecerão oportunamente.

- Dada a complexidade, dinâmica e natureza dos conflitos, buscar-se-á sempre a participação direta das partes envolvidas, identificando a gestão participativa com o sistema de mesas de negociação de conflitos de interesses.

- Em continuidade ao processo, decidem as partes constituir um grupo paritário de trabalho, com a finalidade de apresentar proposta de funcionamento do sistema estipulado, a ser discutida e submetida à apreciação da administração e da categoria, encarregando-se, ademais, de apresentar as presentes reflexões aos demais segmentos da administração e do funcionalismo envolvidos com a questão previdenciária, bem como a seus usuários.

E por entenderem que o presente documento reflete os avanços do processo de reflexão desenvolvido até esta data, subscrevem-no, em nome do consenso, dos interesses maiores da cidadania e da administração pública previdenciária.

\subsection{CONSTITUIÇÃO DO SISTEMA}

postulados, princípios e regras de funcionamento - contratos e convênios

Os protocolos prévios de intenção ou de compromisso são fundamentais para registrar a vontade e a decisão política de adotar um novo modelo de inter-relacionamento. Porém, seu significado é mais político do que prático e esgota-se no ato de sua assinatura. Se nada além disso for feito, nada de novo acontecerá.

A celebraçăo de um protocolo desse tipo não significa instituir instrumentos reais de ação capazes de intervir na realidade que se deseja mudar. E não melhora, necessariamente, sequer a qualidade do relacionamento entre as partes, a exemplo do que ocorreu na Prefeitura do Município de São Paulo (ver comentários no capítulo 3).

Em conseqüência, faz-se necessário avançar as discussōes e produzir instrumentos concretos de intervenção que possibilitem elucidar e fazer a releitura de direitos $\mathbf{e}$ obrigações no campo das relações de emprego e de trabalho no setor público. 
Esses instrumentos são materializados por intermédio da celebração de convênios, de contratos, da instituição de legislação ordinária específica, ou, ainda, por meio do emprego combinado desses procedimentos.

Feitas essas consideraçōes, segue a publicação dos instrumentos de constituição desses sistemas, utilizados nas experiências comentadas. Serão apresentados dois documentos, de formatos diferentes, mas que trataram de assuntos semelhantes. Um, o Sistema Permanente de Negociaçăo Coletiva de Trabalho do IAMSPE, celebrado em 1989, na esfera do Governo do Estado de São Paulo, em vigência (veja protocolos Convênio do Sistema de Gestão Participativa, da Mesa de Negociação do IAMSPE, celebrados em 1995). Outro, o celebrado na esfera do INSS/SP, órgão do Ministério da Previdência e Assistência Social, também vigente.

\title{
EXEMPLO DE CONTRATO: IAMSPE
}

\author{
Sistema Permanente de Negociaçāo Coletiva de Trabalho ${ }^{3}$ \\ INSTRUMENTO DE ADESÄO DE DIREITOS E OBRIGAÇÕES A \\ CONTRATO INDIVIDUAL DE TRABALHO
}

\author{
Título 1 \\ Da Configuração do Processo \\ Capítulo I \\ Das Partes Contratantes
}

Art. 10. Celebram o presente instrumento contratual: Instituto de Assistência Médica ao Senvidor Público Estadual (IAMSPE), Sindicato dos Médicos do Estado de São Paulo, Sindicato dos Trabalhadores da Saúde do Estado de São Paulo, Associação dos Médicos do IAMSPE (AMIAMSPE), Associação dos Funcionários do IAMSPE (AfIAMSPE) e Associação dos Enfermeiros do lAMSPE.

Art. $2^{\circ}$. O instrumento contratual observa a legislação civil e trabalhista vigente e funda-se nos seguintes dispositivos constitucionais:

Constituição Federal,

"Art. 37ำ. VI-é garantido ao servidor público civil o direito à livre associação sindical.

Art. $8^{\circ}$. VI - é obrigatória a participação dos sindicatos nas negociaçōes coletivas de trabalho."

3 Documento firmado em 29/09/89, em vigor, subscrito pelas entidades citadas e pela Secretária-Geral da Mesa, Maria Auxiliadora E. Andrade, e pelo Coordenador convidado Douglas Gerson Braga, escolhidos de comum acordo pelas partes. 
Art. 3․ As entidades sindicais, legalmente autorizadas por intermédio de assembléia geral de seus representados, contratam sobre matéria pertinente às relações individuais e coletivas de trabalho, no âmbito de competência territorial de sua representação, com o IAMSPE, legalmente representado na pessoa do Superintendente, respeitada sempre a competência hierárquica superior à Autarquia.

Art. 49. Celebrado na forma e nos moldes legais e constitucionais, sem vício de qualquer natureza, o presente instrumento detém caráter normativo, podendo ter seu cumprimento exigido administrativa ou judicialmente, individual ou coletivamente na Justiça do Trabaliho.

Art. 59. As cláusulas contratuais de direitos e obrigações contidas neste instrumento incorporam-se aos contratos individuais de trabalho, permanecendo vigentes por prazo indeterminado, e somente podem ser revogadas, alteradas ou substituídas por intermédio de novo acordo coletivo a ser pactuado pelas partes, nos exatos termos do artigo 114, parágrafo segundo da Constituição da República.

\section{Capítulo II \\ Quanto às Finalidades}

Art. $6^{\circ}$. A adoção do Sistema Permanente de Negociação Coletiva de Trabalho expressa vontade da comunidade interna da instituição, no sentido de fixar como seu objetivo central o aperfeiçoamento e a melhoria dos serviços prestados aos usuários do IAMSPE.

Art. $7^{9}$. Entendem as partes que, para se atingirem os objetivos fixados no artigo anterior, é imprescindivel que haja:

a) melhorias das condições de trabalho e do relacionamento hierárquico dentro da esfera de competência do IAMSPE;

b) melhorias no âmbito da resolutividade, do empenho e da eficácia profissional do quadro de funcionários.

Art. $8^{\circ}$. A fixação dos objetivos comuns, definidos no artigo anterior, justifica-se diante das seguintes considerações:

a) finalidade exclusivamente social do órgão público (não tem fins lucrativos);

b) apropriação do fruto do trabalho por uma coletividade de trabalhadores, a quem compete, em parte, a sustentação financeira da instituição;

c) necessidade de se condicionar interesses da comunidade de funcionários do IAMSPE aos interesses-fim da instituição, que é a prestação de serviços assistenciais à saúde do funcionalismo público estadual;

d) entendimento de que, dada a natureza dos serviços, a execução dessa tarefa não pode ocorrer sem que haja empenho e eficiência profissional de todos aqueles que nela estejam envolvidos, direta ou indiretamente. 


\section{Capítulo III \\ Quanto ao Instrumento}

Art. 9o. Entendem as partes que o instrumental mais adequado à consecução do objetivo traçado é a adoção do Sistema Permanente de Negociação Coletiva de Trabalho que significa:

a) estabelecimento de processo de negociação coletiva livre, direta e permanente entre as partes interessadas;

b) formalização, a qualquer tempo, de acordos protocolares, escritos, específicos, de caráter normativo;

c) celebração de acordo, anualmente, ou sempre que as partes entenderem necessário, de caráter normativo.

Art. 10‥ A adoção deste Sistema, como instrumento para mediação de conflitos, implica reconhecimento e garantia dos seguintes princípios básicos:

a) liberdades sindicais: nos termos constitucionais, em seus aspectos organizativos e de exercício da atividade sindical;

b) autonomia da negociação: não ingerência do Poder Judiciário, de outros órgăos públicos ou de terceiros, durante o processo de negociação, observado o princípio da indisponibilidade do interesse público;

c) racionalização da burocracia: adaptação da burocracia ao processo negocial, eliminaçăo dos excessos, agilidade na busca de soluções, agilidade na execução de medidas;

d) livre acesso à informação: as partes não podem se furtar a fornecer informaçōes pertinentes à matéria negocial;

e) negociação permanente: a parte está obrigada à negociação quando solicitada pela outra parte ou pela Coordenação do Sistema;

f) autonomia das partes: o Sistema de Contratação não significa cooptação política de uma parte pela outra. A administração buscará sempre a via negocial para tratamento das questōes que envolvam o funcionalismo. Nāo se furtará, contudo, às suas responsabilidades e atribuições administrativas. Por outro lado, as entidades sindicais não têm responsabilidade administrativa. Não se está estabelecendo um sistema de co-gestão. Mantêm sua completa autonomia como entidades representativas dos interesses dos servidores;

g) equilíbrio político: o equilíbrio entre a autonomia de interesse e a consecução dos objetivos comuns repousa na sensibilidade política das partes para que o Sistema resulte eficaz.

h) consulta aos interessados: possibilidade de consulta permanente junto aos usuários, através de suas entidades de classe (Comissão Consultiva Mista ), para a busca de soluçōes e de sugestões relativas a impasses no funcionamento do Sistema.

Art. $11^{\circ}$. Sempre que houver impasse ou dificuldades conceituais, as partes deverão recorrer aos princípios e objetivos definidos nos artigos anteriores como fonte de argumentação. 
Art. $12^{9}$. A distorção dos objetivos e a năo-observância dos princípios mencionados colocarão em risco a existência do Sistema, devendo a responsabilidade ser imputada ao descumpridor.

\section{Título II}

Do Funcionamento do Sistema

\section{Capítulo I \\ Da Constituiçāo da Mesa de Negociação}

Art. 13․ A Mesa de Negociação será constituída, de forma paritária, por representantes das entidades do funcionalismo do IAMSPE, por representantes da sua administração e por um Coordenador e um Secretário-Geral.

$\$ 10$. O número preciso dos representantes e a definição das entidades sindicais que deverăo participar da Mesa depende da matéria, objeto da negociação, e de acordo entre as partes.

$\S 2$. Havendo dúvida quanto às especificações das entidades sindicais, observar-se-á, sempre, o critério da legitimidade de representação e da vontade majoritária dos interessados.

Art. 149. O Coordenador e o Secretário-Geral da Mesa de Negociação serão escolhidos, preferencialmente, de comum acordo entre as partes.

$\$ 10$. Inexistindo acordo caberá à administração indicar o Coordenador e às entidades sindicais o Secretário-Geral.

$\S 2$. Coordenador e Secretário, quando funcionários da casa, serão liberados do trabalho para o exercício de suas atividades, sem prejuízos salariais, durante a realização dos trabalhos da Mesa de Negociação.

$\S 3$ ㅇ. As atribuições do Coordenador e do Secretário-Geral serão definidas de comum acordo pelas partes.

\section{Capítulo II \\ Da Competência Material}

Art. 150. A Mesa de Negociação tem, em princípio, competência para apreciar qualquer matéria a ela submetida, que envolva, direta ou indiretamente, interesses da instituição e/ou de seus funcionários, desde que, por força de lei, não seja matéria de competência exclusiva de outro órgão ou entidade, e que não implique interferência na esfera de competência exclusiva dos órgãos administrativos. 


\section{Capítulo III \\ Dos Procedimentos}

(Iniciativa, Periodicidade, Registro dos Atos, Formalização dos Atos, Respostas e Prazos, Infra-estrutura)

Art. 16‥ Qualquer das partes poderá apresentar reivindicações ou questões do interesse da instituição à Mesa de Negociação Coletiva.

Art. $17^{\circ}$. O processo negocial é permanente e a Mesa de Negociação deve-se reunir sempre que convocada por uma das partes, pelo Coordenador ou pelo Secretário-Geral.

Art. $18^{\circ}$. Os assuntos tratados na Mesa de Negociação serão registrados, de forma sintética, em atas de reunião, pelo Secretário-Ceral.

Art. 19․ As reivindicaçōes e questóes trazidas pelas partes, bem como a respectiva resposta, réplica, tréplica etc. deverão ser sempre escritas.

Art. 20․ A contra-parente, a quem é dirigida a questão, está obrigada a apresentar resposta de forma escrita, em prazo estabelecido preferencialmente de comum acordo, ou, não sendo possível, fixado pela Coordenação, que não poderá ultrapassar trinta dias, prorrogáveis por acordo das partes.

Art. $21^{\circ}$. Sempre que houver acordo sobre determinada matéria, este deverá ser formalizado através de Protocolo da Mesa de Negociação Coletiva de Trabalho Termo de Adição de Direitos e Obrigações a Contrato Individual de Trabalho.

Art. 22․ Todos os documentos pertinentes ao processo negocial serão arquivados e estarão à disposição de qualquer interessado.

Art. $23^{\circ}$. A administração cuidará da infra-estrutura adequada ao funcionamento do Sistema.

Art. 240. Os atos, formalidades e procedimentos burocráticos, estabelecidos neste e em outros capítulos, serão sempre dosados no sentido de auxiliar o processo negocial e não de inviabilizá-lo.

\section{Título III}

Dos Instrumentos Contratuais de Formalizaçāo de Direitos e Obrigações

\section{Capítulo I \\ Da Capacidade das Partes}

Art. 25․ Os resultados advindos do presente sistema contratual dependem única e exclusivamente das partes, que neste ato, declaram-se livres e aptas para contratar direitos e obrigaçōes em nome de seus representados, observado o seguinte:

a) em relação às entidades sindicais: que haja aprovação e autorização dos interessados, manifestada em assembléia geral, realizada nos termos dos estatutos da respectiva entidade;

b) em relação ao IAMSPE: que haja concordância formal do Superintendente da instituição. 
Parágrafo Único. Havendo fundado receio, evidente questionamento e dúvidas quanto à legitimidade de representação da entidade, e sendo o acordo notoriamente desfavorável aos funcionários, este será considerado nulo para todos os fins e efeitos legais.

\section{Capítulo II}

\section{Do Sistema Permanente de Negociação Coletiva de Trabalho}

Art. 26․ O presente instrumento, denominado Sistema Permanente de Negociação Coletiva de Trabalho, celebrado nos termos da legislação vigente, da Constituição da República e da livre vontade das partes, observados os preceitos nele contidos, possui as seguintes características:

a) tem por objetivo as relações de trabalho dentro do âmbito de competência da instituição; inclusive a discussão de salários, condições de trabalho etc.;

b) obriga as partes contratantes e seus representados para todos os efeitos legais (caráter normativo);

c) tem vigência por prazo indeterminado;

d) pode ser alterado, a qualquer tempo, por consenso das partes.

Art. 27․ Nos termos da legislação vigente da Constituição da República e observados os preceitos ora fixados, as partes estabelecem os seguintes instrumentos contratuais.

I - Protocolo da Mesa de Negociação Coletiva do Trabalho.

II - Acordo Coletivo de Trabalho.

III - Convenção ou Contrato Coletivo de Trabalho.

\section{Capítulo III \\ Dos Protocolos da Mesa de Negociação}

Art. 28ㅇ. Protocolos da Mesa de Negociação Coletiva de Trabalho e Termos de Adesão de Direitos e Obrigaçóes a Contratos Individuais de Trabalho são acordos coletivos de trabalho específicos sobre uma ou sobre um lote de reivindicações, celebrados entre as entidades representativas do funcionalismo do IAMSPE e sua administração, com os seguintes atributos:

a) objeto: relaçōes e condições de trabalho;

b) eficácia: caráter normativo; adere ao contrato individual de trabalho como direto e/ou como obrigaçáo; pode ser exigido judicialmente, de forma individual ou coletiva;

c) abrangência: depende da matéria negocial;

d) periodicidade: pode ser celebrado a qualquer tempo;

e) quantidade: não há limitação quanto ao número;

f) vigência: por prazo indeterminado; somente revogável por vontade das partes, através de outro instrumento contratual. 


\section{Capítulo IV \\ Do Acordo Coletivo de Trabalho}

Art. 290. Acordo Coletivo de Trabalho é o contrato de caráter normativo, celebrado entre as entidades representativas do funcionalismo do IAMSPE e sua administração, da seguinte forma:

a) é celebrado anualmente, a partir da assinatura do primeiro;

b) é negociado de forma a demarcar o encerramento de um período negocial e o advento de outro;

c) é constituído, inicialmente, pelos Protocolos da Mesa de Negociação Coletiva do Trabalho, firmados no período, que, após sua inserção no Acordo, deixam de existir, sem prejuízo da eficácia do seu conteúdo;

d) podem integrá-lo, ainda, novas cláusulas resultantes da negociação do próprio acordo coletivo, desenvolvidas no período de sua celebração.

Art. $30^{\circ}$. O Acordo Coletivo de Trabalho possui os seguintes atributos:

a) objeto: relações e condições de trabalho;

b) eficácia: caráter normativo; adere ao contrato individual de trabalho, como direito e/ou como obrigação; pode ser exigido judicialmente, de forma individual ou coletiva;

c) periodização: anual;

e) quantidade: um;

f) vigência: por prazo indeterminado; somente revogável por vontade das partes, através de outro instrumento.

\section{Capítulo V \\ Da Convenção ou Contrato Coletivo de Trabalho}

Art. $31^{\circ}$ - Convenção ou contrato coletivo de trabalho é o instrumento a ser celebrado entre as entidades representativas dos funcionários públicos do setor de saúde ou de todo o funcionalismo estadual e suas respectivas administrações.

Art. $32^{\circ}$ - O IAMSPE não detém competência legal para celebração deste convênio de trabalho.

Art. $33^{\circ}$ - As partes reconhecem a importância da celebração da convenção/contrato coletivo de trabalho, em nível geral dos senvidores da saúde e do funcionalismo estadual, de forma a se estabelecer o processo negocial em toda a sua plenitude.

Por entenderem que as disposições ora contratadas expressam a soberana vontade das partes e de seus representados, assinam, livremente, em tantas vias de igual teor, o presente Sistema Permanente de Negociação Coletiva de Trabalho, para todos os fins e efeitos legais. 


\section{EXEMPLO DE CONVÊNIO: INSS}

\section{Convênio do Sistema de Gestão Participativa ${ }^{4}$}

\section{Constituição}

Cláusula Primeira. Sistema de Gestáo Participativa (SCP) é o conjunto de postulados, princípios, procedimentos e regras de funcionamento que se constitui em instrumento de formalização de compromisso dos partícipes, em torno dos objetivos comuns a que se propóem atingir.

Cláusula Segunda. Os signatários deste compromisso são: o Instituto Nacional do Seguro Social (INSS), através da sua Coordenação de Arrecadação e Fiscalização no Estado de São Paulo (CAF/SP) e o Sindicato dos Fiscais de Contribuições Previdenciárias de São Paulo (SINDIFISP/SP).

Cláusula Terceira. O SGP serve à eficácia e à democratização do processo de tomada de decisōes. Não se constitui em co-gestão administrativa. Não repassa responsabilidades administrativas ao Sindicato. Não impõe limitações ao exercício constitucional da atividade sindical. Os partícipes mantêm-se autônomos e ficam intactas suas atribuições legais na defesa dos interesses da Instituição.

\section{Objeto}

Cláusula Quarta. O SGP tem por objeto específico dar tratamento e soluçōes aos conflitos que insurgem no processo de trabalho e que afetam, direta e indiretamente, a qualidade, a eficácia e a produtividade dos serviços.

Cláusula Quinta. A apreciação de conflitos, objeto específico do SCP, utilizará como referência e terá como objetivos maiores a busca permanente da melhoria e do aperfeiçoamento da qualidade, da eficácia e da produtividade dos serviços requeridos pela população.

\section{Postulados}

Cláusula Sexta. Para a consecução dos objetivos maiores estabelecidos na cláusula anterior, entendem os partícipes ser imprescindível o aprimoramento do aparelho administrativo, especialmente quanto aos seguintes itens.

I. preparação e adequação do quadro funcional, através da contratação por concurso público, correta distribuição, qualificação profissional e remuneração digna dos servidores;

II. melhoria no âmbito da resolutividade, da produtividade, do empenho e da eficácia profissionai dos servidores;

4 Convênio firmado em 27/09/94, em vigor, subscrito pelas seguintes entidades: CAF/INSS/SP, Ayda Tereza Sonnesen Losso, Coordenadora, e SINDIFISP/SP, Carmelina Calabrese Nunes, Presidente. 
III. reforços e investimentos nas áreas de informática, em equipamentos e nas condiçōes materiais e físicas para a realização do trabalho;

IV. profissionalização e continuidade administrativa nos escalōes superiores da administração previdenciária;

V. adoção de iniciativas que estimulem e proporcionem mudanças de posturas culturais de servidores, administradores e de usuários dos serviços previdenciários.

\section{Princípios}

Cláusula Sétima. A reger o presente Sistema, destacam-se os seguintes princípios:

I. da indisponibilidade do interesse público, pelo qual o administrador não pode omitir-se ou emitir providências que contrariem os interesses dos cidadãos-usuários e da Administração Pública;

II. da legalidade, segundo o qual faz-se necessário que o escopo da lei dê guarida às ações do administrador público;

III. do livre exercício da atividade sindical, pelo qual o legislador constituinte conferiu legitimidade de defesa aos interesses específicos dos servidores públicos, através da organização sindical.

IV. da transparência administrativa, significando acesso às informações pertinentes ao funcionamento do processo;

V. da finalidade, significando o reconhecimento da sobreposição dos interesses fim da Administração Pública sobre os demais interesses que interagem na sua viabilização;

Vl. da globalidade, significando o compromisso de todos os atores da administração previdenciária com o seu resultado final e não apenas com parte específica dele;

VII. da democratização do tratamento dos conflitos, significando o reconhecimento da natureza eminentemente conflituosa das relações de trabalho, da participação direta das partes interessadas e do caráter permanente do processo.

\section{Procedimentos}

Cláusula Oitava. O SGP observará os seguintes procedimentos, dentre outros que vierem a ser estabelecidos:

1. prerrogativa e liberdade da pauta para ambos os partícipes, observados os objetivos específicos e gerais ora definidos;

II. formalização e exposição de motivos e de razóes das questóes tratadas em pedidos, respostas, réplicas ou tréplicas;

III. direto de resposta, fixação de prazos e formalização dos resultados obtidos através do sistema.

\section{Regras de funcionamento}

Cláusula Nona. Sendo os conflitos de interesses, sua apreciação e possível composição o objetivo específico deste Sistema e considerando-se a complexidade e a diversidade desses conflitos, adota-se o seguinte mecanismo de funcionamento: 
I. constituição de Mesa de Participação Permanente, a ser integrada por 3 (três) representantes da CAF/SP e 3 (três) do SINDIFISP/SP;

II. instituição de Mesas de Participação Conjunta, integradas, paritariamente, por representantes da Administração e do Sindicato, nos locais de trabalho.

Cláusula Décima. Cabe à Mesa de Participação Permanente, afora outras atribuições que estabelecer:

I. definir competência e forma de representação, regular, coordenar e adotar as providências necessárias à sua implantação e ao funcionamento das Mesas de Participação Conjunta, nos locais de trabalho;

II. segundo os postulados, princípios, procedimentos e as regras de funcionamento previstas nestes estatutos, dar tratamento aos conflitos insurgentes, de forma a atender aos objetivos previstos no SGP.

Cláusula Décima Primeira. Nos locais de trabalho, ora definidos como Gerências Regionais de Arrecadação e Fiscalização (GRAFs), fica assegurada, quando não houver, a eleição de um representante sindical por GRAF, que, afora outras atribuiçōes, integrará a Mesa de Participação Conjunta.

Cláusula Décima Segunda. A seu critério e dependendo da disposição dos convidados, a Mesa de Participação Permanente poderá promover a constituição de Comissão Consultiva de Usuários e Contribuintes representados por entidades da sociedade civil, a quem poderá submeter consultas sobre assuntos de interesse comum.

Cláusula Décima Terceira. Ao objetivarem o aprimoramento da qualidade, da eficácia e do nível de resolutividade no atendimento às demandas da cidadania, por intermédio da melhoria da qualidade das condiçōes de realização dos serviços previdenciários, os partícipes declaram-se aptos e desimpedidos para a celebração do presente Convênio, firmado, por prazo indeterminado, em 4 (quatro) vias de igual teor.

\section{Regulamento da Mesa de Participaçāo Permanente (Anexo do Convênio SGP)}

Cláusula Primeira. A Mesa de Participação Permanente terá um Coordenador e um Secretário-Geral, escolhidos, preferencialmente, de comum acordo entre os partícipes.

$\S 7$ 10. Inexistindo acordo, caberá à Administração indicar o Coordenador e às entidades sindicais, o Secretário Geral.

Cláusula Segunda. Ao Coordenador cabe, entre outras atribuições: definir, após consulta aos partícipes quando possível, o local e horário das reuniões; elaborar e encaminhar a pauta de discussão, com antecedência mínima de 3 (três) dias úteis; subsidiar as discussões com estudos e subsídios técnicos; convidar à reunião a participação de pessoa habilitada, servidor ou não, que possa contribuir com a discussão; abrir, coordenar e encerrar as reuniões.

Parágrafo Único. Os partícipes devem apresentar itens à pauta até 5 (cinco) dias antes da realização das reuniōes ordinárias. 
Cláusula Terceira. Ao Secretário-Geral cabe elaborar as atas de reunião e repassá-las aos partícipes para colher suas assinaturas, entre outras atribuiçóes que the forem conferidas.

Cláusula Quarta. A Mesa de Participação tem, em princípio, competência para apreciar qualquer matéria a ela submetida que envolva, direta ou indiretamente, interesses da Instituição desde que, por força de lei, não seja matéria de competência exclusiva de outro órgão ou entidade.

Cláusula Quinta. Qualquer dos partícipes poderá apresentar questốes de interesse da Instituição à Mesa de Participação.

Cláusula Sexta. O funcionamento da Mesa de Participação é Permanente, devendo seus membros reunirem-se, ordinariamente, mensalmente e, extraordinariamente, sempre que convocados pelo Coordenador.

$\$ 19$. Ambos os partícipes podem solicitar ao Coordenador a realização de reunião extraordinária, com antecedência mínima de 3 (três) dias úteis, contados da data requerida para sua realização.

$\S 2^{2}$. O requerimento da reunião extraordinária deverá conter os itens da pauta que conformará a ordem do dia e não poderá ser indeferido pelo Coordenador, a quem caberá designar a data de sua realização, em prazo não superior a sete dias úteis, contados da solicitação.

Cláusula Sétima. Os assuntos tratados na Mesa de Participação serão registrados, de forma sintética, em atas de reunião, pelo Secretário-Geral.

Cláusula Oitava. As questões trazidas pelos partícipes, bem como as respectivas respostas, réplicas, tréplicas etc. deverão ser sempre arrazoadas por escrito.

Cláusula Nona. A contraparte a quem é dirigida a questão obriga-se a apresentar resposta arrazoada e escrita, em prazo estabelecido preferencialmente de comum acordo, ou, não sendo possível, em prazo fixado pelo Coordenador, que não poderá ultrapassar trinta dias, prorrogáveis de comum acordo.

Cláusula Décima. As decisōes da Mesa de Participaçáo serão adotas pela unanimidade dos seus participantes.

Cláusula Décima-Primeira. Sempre que houver acordo sobre determinada matéria, este deverá ser formalizado através de Protocolo da Mesa de Participação Permanente.

Cláusula Décima-Segunda. O Protocolo da Mesa de Participação registra o compromisso do partícipe em dar os encaminhamentos necessários à implementação da decisão acordada.

Cláusula Décima-Terceira. Todos os documentos pertinentes ao SGP serão arquivados e estarão à disposição dos interessados.

Cláusula Décima-Quarta. A Administração cuidará do local e proporcionará condiçőes adequadas ao funcionamento do Sistema.

Cláusula Décima-Quinta. Os casos omissos, as dúvidas e controvérsias relativas à aplicação do presente regulamento serão dirimidas pela Mesa de Participação Permanente. 


\subsection{FORMALIZAÇÃO DOS RESULTADOS}

protocolos de resultados, atas de reunião, encaminhamento de projetos de $\mathrm{ei}^{5}$

Sobre este tópico, é importante reforçar alguns esclarecimentos preliminares. Os resultados das negociações decorrentes da aplicação dos modelos analisados serão formalizados de acordo com as regras e procedimentos previstos nos respectivos contratos, convênios ou legislação reguladora, conforme o caso. Assim, de modo geral, a forma a ser conferida aos itens negociados deverá observar o que estiver prescrito no modelo adotado e dependerá, substancialmente, do conteúdo da matéria negociada.

Para fins didáticos, pode-se dividir o conteúdo dessas matérias, objeto de acordo na Mesa de Negociaçăo, em dois tipos, a saber: a) matérias cuja competência para tomar decisóes é de alçada exclusiva do administrador que negocia; b) matérias que dependam da interveniência de outro(s) órgão(s) da administração ou de outro Poder. São exemplos do primeiro tipo: mudanças em escalas de plantōes de médicos; introdução de novos padrões de atendimento ao público; introdução de procedimentos de avaliação de servidores; introdução de mecanismos de controle de qualidade e de produtividade; mudanças na organização do trabalho e na execução de tarefas e até mesmo algumas hipóteses de interpretação de normas que envolvam pequenos acréscimos de despesas. São exemplos do segundo tipo: acordo sobre jornada de trabalho e decisões que impliquem aumento de despesas com a folha de pagamento. Nesta última hipótese, por exemplo, caso não haja previsão orçamentária, a decisăo dependerá de autorização legislativa e envolverá, portanto, as mais altas instâncias da Administração Pública e o Poder Legislativo.

Em qualquer caso, no entanto, o acordo entre as partes poderá ser registrado em protocolos de resultados da Mesa de Negociação ou apenas em atas de reunião. A diferença fundamental será verificada quanto à qualidade e quanto aos efeitos que geram. Nas hipóteses do primeiro tipo os efeitos sāo imediatos, uma vez que o administrador detém competência para transformar a decisão negociada em ato administrativo específico, revestido das exigências prescritas pelas normas da administração pública. Já para as negociaçōes do segundo tipo registram-se, no protocolo de resultados ou em atas de reunião, o compromisso, a intenção, o empenho das partes, quanto ao objeto do acordo e os encaminhamentos necessários para efetivação dos acordos feitos na Mesa de Negociação.

Para finalizar a aplicação do Roteiro em Seis Passos, e seguindo a metodologia de demonstrar, por meio de exemplos concretos, o funcionamento das experiências estudadas, serão transcritos alguns procedimentos de formalização de resultados decorrentes da aplicação dos modelos no lAMSPE (contrato) e no INSS (convênio).

5 Sobre resultados colhidos por meio de negociação, veja textos analíticos sobre as experiĉncias desenvolvidas, no capítulo 3, inclusive o processo negociado de redução da jornada de trabalho no Município de Campinas. Veja, ainda, análise sobre o processo de Avaliação Integrada desenvolvido pelo SGP do INSS no estado de São Paulo. 


\section{Funcionamento e Resultados da Aplicação do Sistema no lAMSPE}

Entre os inúmeros Protocolos da Mesa de Negociação Coletiva de Trabalho do IAMSPE, um regulou o exercício da atividade sindical em suas dependências, outro tratou da licença-maternidade pós-constituinte. Estes assuntos, em 1988/1989, eram objeto de inúmeras controvérsias jurídicas e fonte abundante de conflitos. Transcrevese, para conhecimento mais preciso do funcionamento do sistema no Instituto, a íntegra desses dois protocolos, celebrados no início do processo. E já que o Sistema Permanente de Negociação Coletiva de Trabalho do IAMSPE continua em vigor, também serăo transcritos dois protocolos celebrados em 1995.

\section{Protocolo da Mesa de Negociaçāo Coletiva do Trabalho - Termo de Adiçăo de Direitos e Obrigaçōes a Contrato Individual de Trabalho}

Referência: Liberdade Sindical 6
№ $09 / 89$.

Tendo em vista alcançar melhorias na qualidade dos serviços prestados pela instituição a seus usuários, objetivo expresso de forma consensual pelas partes que compõem o Sistema Permanente de Negociação Coletiva de Trabalho - mecanismo instituído para solucionar questóes administrativas de interesse comum e como instrumento de composição direta de conflitos e de defesa de direitos trabalhistas - os subscritores do presente Termo de Adição de Direitos e Obrigações a Contrato Individual de Trabalho,

considerando:

- a necessidade de esclarecer e assegurar o efetivo exercício da atividade sindical, sempre em consonância com os fins maiores da instituição que é a prestação de serviços de saúde a uma coletividade de trabalhadores;

estabelecem:

1. Estabilidade no emprego a todos os dirigentes das entidades subscritoras do presente contrato de trabalho, da inscrição da candidatura até um ano após o término da gestão, salvo demissão por cometimento de falta grave, devidamente apurada e comprovada, conforme legislação vigente, nos termos da Constituição da República.

2. Liberação do trabalho:

a) para exercício da atividade sindical, sem prejuízos salariais e assegurados todos os direitos, como se trabalhando permanecessem, de três dirigentes para cada entidade subscritora do presente;

b) de um funcionário indicado pelas entidades representativas para acompanhamento e assistência aos trabalhos da Mesa de Negociação Coletiva, sempre que requisitada.

6 Protocolo celebrado em 16/08/89, subscrito pela Superintendência do laMsPE (José Carlos Ramos de Oliveira); AfıAMSPE/Sindicato Trabalhadores da Saúde (Presidência); Aviamspe/Sindicato dos .Médicos (Presidência) Diretoria do HD (David Braga Júnior) e pela Coordenaçăo do Sistema (Douglas G. Braga). 
3. Direito de reunião com fins sociais, científicos ou de interesse trabalhista, para entidades internas, observados os procedimentos administrativos e a escala de uso. Com prévia e especial autorização da administração para as entidades externas.

4. Desconto em folha de pagamento das mensalidades sociais destinadas às entidades sindicais.

5. Participação nas comissỏes científicas, de trabalho e outras, de comum acordo entre as partes, criadas pela administração do IAMSPE, pertinentes a questões de interesse da instituição e/ou de seus funcionários.

6. Direito de uso de área e de exploração econômica da lanchonete e da livraria, conforme acordo estabelecido anteriormente.

7. Direito à comunicação direta:

a) alto-falantes - liberação do uso dos alto-falantes, com texto lido pela telefonista, para convocação de reuniões sociais, científicas ou de interesse trabalhista, com uso moderado, de forma a não provocar intranqüilidades aos pacientes e usuários, observados os procedimentos administrativos internos;

b) visual - comunicação através da afixação de cartazes, folhetos etc. nos murais das entidades sindicais. Faixas poderão ser afixadas, uma na entrada da rua Pedro de Toledo, outra na entrada da rua Borges Lagoa. As partes se comprometem a evitar excesso de poluiçăo visual, em respeito aos usuários.

8. Mobilização: o exercício das liberdades sindicais no HD, em conformidade com as normas constitucionais, é pleno e deve ser exercido, sempre, em níveis compatíveis com o exercício da atividade médico-hospitalar, em absoluto respeito aos pacientes e usuários da instituiçăo.

Por entenderem que tal procedimento constitui interesse comum das partes, beneficiando, conseqüentemente, os usuários da instituição, firmam livremente o presente instrumento contratual, de caráter normativo, cujo cumprimento poderá ser exigido, de forma individual ou coletiva, por qualquer das partes.

\section{Protocolo da Mesa de Negociaçāo Coletiva do Trabalho - Termo de Adição de Direitos e Obrigaçōes a Contrato Individual de Trabalho}

Referência: Licença-maternidade
№ 04/89

Tendo em vista alcançar melhorias na qualidade dos serviços prestados pela instituiçăo a seus usuários, objetivo expresso de forma consensual pelas partes que compõem o Sistema Permanente de Negociação Coletiva de Trabalho - mecanismo instituído para solucionar questóes administrativas de interesse comum e como instrumento de composiçăo direta de conflitos e de defesa de direitos trabalhistas - os subscritores do presente Termo de Adição de Direitos e Obrigações a Contrato Individual de Trabalho, 
considerando:

1. a necessidade de adaptação às normas constitucionais vigentes;

2. a necessidade de consolidar a harmonia no local de trabalho e a autoridade hierárquica moral da administração;

estabelecem:

1. O reconhecimento da auto-aplicabilidade da norma constitucional que assegura às gestantes licença-maternidade de 120 dias, nos termos do artigo. $7^{\circ}$, inciso XVII e XXXIX, parágrafo $2^{\mathbf{o}}$ da Constituição da República, a partir da data da sua promulgação, ou seja, 5 de outubro de 1988.

2. Para correção de erro decorrente da não-observância da norma durante determinado periodo, ocasião em que as gestantes completaram o período de licença com a utilização do período de férias ou simplesmente retornaram ao trabalho trinta dias antes do término da licença, adotam as seguintes providências:

a) devolução do período aquisitivo de férias para a primeira hipótese;

b) pagamento do salário para o período correspondente ao segundo caso.

Por entenderem que tal procedimento constitui interesse comum das partes, beneficiando, conseqüentemente, os usuários da instituição firmam livremente o presente instrumento contratual, de caráter normativo, cujo cumprimento poderá ser exigido, de forma individual ou coletiva, por qualquer das partes.

\section{Protocolo da Mesa de Negociaçāo Coletiva de Trabalho ${ }^{7}$}

Referência: Concessão de 2 (dois) períodos de férias anuais de 20 (vinte) dias corridos aos Técnicos de Radiologia

Com a finalidade de buscar melhorias na qualidade dos serviços prestados pela Instituição aos usuários, conseqüentemente, por meio do Sistema Permanente de Negociação Coletiva - Mesa de Negociação, os subscritores do presente Termo de Adição de Direitos e Obrigações a Contrato Individual de Trabalho,

considerando:

1. que todos os Técnicos de Radiologia, alguns através de decisões administrativas e outros por meio de decisões judiciais, passaram a fazer jus e a usufruir de 2 (duas) férias de 20 (vinte) dias corridos anualmente;

2. que existem apenas 21 (vinte e um) técnicos que estăo excluídos desse benefício, e que esse procedimento vem causando transtornos à unidade de Radiologia em virtude do descontentamento causado por tal desigualdade;

3. que a Constituição Federal, em seu artigo 5ㅇ, estabelece a igualdade de todos perante a lei;

7 Protocolo celebrado em 01/05/95, subscrito pela Superintendência do lAMSPE, AfIAMSPE e pelos servidores técnicos em Radiologia (não há identíicação dos signatários). 
4. que o inciso XXXII, do artigo $7^{\circ}$ da Constituição da República, veda a distinção entre trabalhado manual, técnico e intelectual ou entre os profissionais respectivos;

5. finalmente, que os signatários do presente, Técnicos de Radiologia, por livre e espontânea vontade, abrem mão do direito de reclamar, administrativa ou judicialmente, eventuais períodos de férias vencidas anteriormente à assinatura do presente protocolo;

estabelecem:

1. que a partir de 01/05/95, data da assinatura do presente protocolo, fica estendido o direito ao gozo de 2 (dois) períodos de férias anuais, de 20 (vinte) dias corridos aos técnicos de Radiologia abaixo assinados;

2. que a decisão aqui adotada é extensiva aos demais profissionais, técnicos de Radiologia, que vierem a ser admitidos após essa data.

Finalmente, por entenderem que os procedimentos aqui previstos, constituem interesse comum das partes, em benefício dos usuários da Instituição, firmam livremente o presente instrumento contratual, de caráter normativo, cujo cumprimento pode ser exigido de forma individual ou coletiva, por qualquer das partes.

\section{Protocolo da Mesa de Negociação Coletiva de Trabalho - Termo de Direitos e Obrigaçōes a Contrato Individual de Trabalho ${ }^{8}$}

Referência: Pagamento do valor relativo a 02 (duas) horas extras e DSRs, correspondentes a todos os médicos incluídos no Sistema de Plantōes do HSPD/FMO, a título de contraprestação pelo exercício da atividade de Preceptor de Ensino.

Com a finalidade de buscar melhorias na qualidade dos serviços prestados pela Instituição aos usuários, objetivo esse expresso de forma consensual pelas partes que compõem o Sistema Permanente de Negociação Coletiva de Trabalho, mecanismo este legalmente instituído para a solução de questões administrativas de interesse comum, e, instrumento de composição direta de conflitos e de defesa de direitos trabalhistas, os subscritores do presente Termo de Adição de Direitos e Obrigações a Contrato Individual de Trabalho,

considerando:

1. a necessidade de racionalizar e adequar os procedimentos e atividades dos médicos integrados no Sistema de Plantōes do HSPD/FMO;

2. a necessidade de proporcionar aos médicos, residentes e internos, a possibilidade de continuidade de seu aprendizado, também nos horários cujo atendimento médico é efetuado por sistema de plantões noturnos de $2^{\underline{a}}$ a $6^{\text {a }}$ feira e sábados, domingos e feriados, noturnos e diurnos;

8 Protocolo celebrado em maio de 1995, subscrito pela Superintendência do IAMSPE e pala AFIAMSPE (não há identificação dos signatários). 
3. que os médicos, quando em regime de plantāo, já executam tal atividade (ensino), dando orientaçáo e ministrando aulas aos residentes e internos escalados naquele plantão, sem contudo nada receber a esse título;

4. que, do total de médicos integrados no sistema de plantóes, apenas cerca de 247 (duzentos e quarenta e sete) não são considerados, oficialmente, preceptores, e, por isso mesmo, nada recebem por essa atividade, ficando em situação de desigualdade frente aos demais;

5. que a atividade de médico preceptor é objeto de regulamentação, através de proposta a ser encaminhada ao Governo de Estado, e que sua implantação imediata se reveste de urgência, sob pena de graves conseqüências ao Sistema de Plantōes, com reflexos no ensino ministrado aos Residentes e Internos;

estabelecem:

1. o médico plantonista identificado e em referência no presente protocolo é o profissional médico, regularmente integrado em 1 (uma) equipe ou subequipe, com a média mensal de, no mínimo, 4 (quatro) plantões de doze horas;

2. a partir de 01/05/95, será considerado na remuneração do médico plantonista o valor correspondente a 2 (duas) horas extras, acrescido dos respectivos DSRs, a título de pagamento pelo exercício da atividade de Preceptor de Ensino;

3. a atividade do médico preceptor não está adstrita ou atrelada a carga horária, devendo ser considerada como normal, desenvolvida nas doze horas do plantão;

4. a deliberação dessa mesa de negociação será objeto de termo aditivo de reti-ratificação no Contrato de Trabalho do Médico Plantonista;

5. ficam excluídos do presente protocolo os substitutos eventuais, entendendose como tal o profissional não integrado nas equipes ou subequipes.

Finalmente, por entenderem que os procedimentos aqui previstos constituem interesse comum das partes, beneficiando, conseqüentemente, os usuários da instituição, firmam livremente o presente instrumento, de caráter normativo, cujo cumprimento pode ser exigido de forma individual ou coletiva por qualquer das partes.

\section{Funcionamento e Resultados da Aplicação do Sistema no INSS $^{9}$}

No curto período em que teve aplicaçăo prática, os resultados obtidos do Sistema de Gestão Participativa no INSS/SP foram registrados em documentos encaminhados pelo Sindicato ou pela Administração à Mesa de Participação Permanente, e também em atas das suas reunióes.

Para conhecimento do processo então desenvolvido, serão transcritos dois dos procedimentos realizados.

9 Veja análise, comentários e avaliação no capítulo LLL do mesmo texto. 
Um deles trata da reivindicação apresentada pela entidade sindical de Avaliação Interna das Gerencias Regionais. O processo de discussão da Mesa de Participação em torno desse assunto culminou com a aprovação, por consenso, da Avaliação Integrada, um dos mais democráticos e participativos procedimentos de avaliação já praticados no setor público, que contou, inclusive, com a avaliação dos superiores por seus subordinados.

Outro procedimento, transcrito a seguir, trata de diversos itens, dentre os quais consta a instituição do Grupo de Estudos de Previdência, constituído paritariamente, responsável por pesquisas, estudos e propostas de Reforma Previdenciária, apresentados em formato de livro, editado pelo SINDIFISP/SP em 1995.

\section{Carta $\mathrm{n}^{\mathrm{O}} 320 / 94^{10}$}

É a presente para elencar itens de pauta para a reunião extraordinária, conforme nossa solicitação de 27/09/94, tendo como data de sugestão entre 04 a 06/10/94, a saber:

1. Forma de publicidade do Convênio do Sistema de Gestão Participativa

\section{Justificativa}

Para que o convênio firmado entre as partes tenha caráter público, sugerimos que o mesmo seja publicado no Boletim de Serviço Local.

2. Planejamento da Ação Fiscal e Produtividade

- solicitação de envio ao SINDIFISP/SP de informações permanentes e detalhadas sobre os resultados mensais alcançados durante o ano de 1994, bem como os futuros;

- planejamento da ação fiscal do quarto trimestre de 1994;

- planejamento da ação fiscal para o exercício 1995;

- discussão dos aspectos técnicos e políticos da OS 113/94.

\section{Justificativa}

Os dados acima visam subsidiar tecnicamente um grupo de trabalho a ser proposto na citada reuniāo, com o objetivo de colaborar com a CAF na avaliação dos resultados pretéritos e futuros da ação fiscal dentro da programação estabelecida pela Coordenação, bem como seus reflexos na produtividade individual e global do contingente fiscal, na vigência da OS 113/94.

10 Documento encaminhado pelo SINDIFISP/SP, em 29/09/94, propondo itens de pauta para reunião da Mesa de Negociaçăo Permanente. 
Autorização de transferência do período de gozo para o exercício seguinte.

\section{Justificativa}

Tendo em vista determinação que impossibilita a transferência de período de gozo das férias para o exercício seguinte, o que tem impedido o FCP de acumular, a título de reserva, um período aquisitivo para uma possível necessidade, solicita-se a revogação da medida uma vez que:

- é de âmbito estadual;

- não altera a produção projetada pela CAF, uma vez que esta tem competência para autorizar ou não o mês escolhido pelo servidor;

- não há impedimento legal;

- dificilmente há o gozo, pelo servidor, de dois períodos consecutivos no mesmo exercício.

4. Formação de Grupo de Estudos de Previdência Pública

Grupos formados a partir de indicados pelo SINDIFISP/SP e pela CAF/SP.

\section{Justificativa}

Tendo em vista mudança de governo para o próximo ano e programas de governo divulgados pelos partidos no sentido de reformular a Previdência Social, sentimos necessidade de a categoria de Fiscais de Contribuições Previdenciárias ter estudo de um Projeto de Previdência Social.

5. Plantão Fiscal - Negociação de uma padronização mínima

\section{Justificativa}

A partir de tabulação de questionário respondido por representantes das GRAFs do estado de São Paulo, faz-se necessário que se estabeleça negociação de normas mínimas de plantão fiscal.

No aguardo de confirmação prévia da data da reunião, subscrevemo-nos com cordiais saudaçōes.

\section{Referência: Convênio do Sistema de Gestāo Participativa ${ }^{11}$}

A Coordenação de Arrecadação e Fiscalização CAF - INSS/SP vem, por intermédio do presente, em atenção ao disposto na Cláusula Nona do Regulamento da Mesa de Participação Permanente, posicionar-se sobre as questóes apresentadas

11 Documento encaminhado pela CAF/INSS/SP à Mesa de Negociaçäo Permanente, em 11/10/1994. 
formalmente pelo SINDIFISP/SP, tratadas em Reuniăo Extraordinária, requerida pela entidade sindical, realizada em 11 de outubro de 1994, nos seguintes termos:

1. Forma e Publicidade do Convênio do Sistema de Gestão Participativa

CAF - O Convênio será publicado no Boletim de Serviço Local.

\section{Planejamento da Ação Fiscal e O.S. no 123/94}

CAF - A Administração tem interesse na transparência, na difusão dos dados e no maior envolvimento dos fiscais nas discussões sobre planejamento da ação fiscal, arrecadação e produtividade.

Encaminhará, periodicamente, à entidade sindical, o Boletim Informativo produzido por sua Divisão de Fiscalização que contém dados, informações e análises referentes à matéria, satisfazendo, assim, a solicitação da entidade, em conformidade com os interesses da Administração.

Para discutir Produtividade e O.S. n 123, a CAF propõe a realização de reunióes conjuntas e específicas, com o objetivo de promover estudos que proporcionem novas abordagens conceituais sobre o tema.

\section{Férias do Servidor - Lei $8.112 / 90$}

CAF - A Administração coíbe a prática de ratificar pedidos de transferência de férias de servidores, encaminhados sob a Justificativa genérica e não comprovada de 'interesse do serviço'.

A prerrogativa do administrador em autorizar a transferência de férias não pode ser utilizada segundo critérios subjetivos. Segundo a lei, tal prerrogativa tem que se fundar em razões concretas, sempre relacionadas aos interesses e às necessidades do serviço e da Administração. Caso contrário, na ausência de critérios objetivos, estimular-se-iam o clientelismo e o despotismo administrativos.

A regra é a não-transferência. A transferência constitui prerrogativa excepcional, galgada, sempre, em fundado interesse do serviço. Nada obsta, contudo, que, afora os casos mais visíveis e objetivos de 'interesse do serviço', este conceito ganhe contornos e critérios que permitam reconhecer situações de convergência entre interesses da Administração e interesses específicos do servidor. Exemplo: uma viagem de estudo ao exterior que necessite usufruir dois períodos seguidos de férias.

Nunca é demais lembrar que a grande maioria do contingente fiscal já tem, à sua disposição, a licença-prêmio de três meses e pode contar, também, com o gozo antecipado das férias, em caso de interesse exclusivamente pessoal.

Neste sentido, a CAF propôe ao Sindicato a discussão em torno de critérios objetivos e transparentes, alcançados pelo conceito de interesse do serviço e da administração para, em caráter excepcional, fundar pedido individualizado de transferência de férias. 


\section{Formação de Grupo de Estudo de Previdência Pública}

CAF - Há interesse da Administração em estimular a formação e o preparo de quadros que possam assumir e participar das discussōes estruturais a respeito das reformas do sistema previdenciário brasileiro. $O$ mesmo interesse se manifesta na produção de subsídios a serem utilizados pela própria Administração e por outros setores da sociedade envolvidos nesta discussão.

Há concordância, portanto, com a proposta de constituição de Grupo de Trabalho de Fiscais, subordinado e coordenado diretamente pela CAF, ao qual deverá competir diagnosticar, analisar, produzir dados e formular estudos e propostas referentes ao tema, segundo roteiro previamente estabelecido.

\section{Plantão Fiscal - Padronização Mínima}

CAF - Recebido para estudo documento/pesquisa contendo sugestões, recolhidas junto às GRAFs, para aperfeiçoar o Plantão Fiscal. Nada obsta que sejam estabelecidas ou reexaminadas regras básicas, mínimas, de funcionamento do Plantão Fiscal. A matéria deve permanecer em discussão.

\section{Ata da reuniāo extraordinária da Mesa de Negociação Permanente, realizada em $11 / 10 / 94^{12}$}

Aos onze dias do mês de outubro de 1994, reuniram-se os Representantes da CAF/SP, Ayda Tereza Sonnesen Losso, Valdir Moyses Simão e Douglas Gerson Braga e os diretores do SINDIFISP/SP, Carmelina Calabrese Nunes, José Américo Pereira do Amaral e Jairo Diniz Dantas, para darem encaminhamento às negociações da pauta apresentada pelo SINDIFISP/SP em 29/09/94. Foram as seguintes as deliberações: 1 . Forma de publicidade do convênio do Sistema de Gestão Participativa - Nesta reunião foi aprovado o regulamento do convênio e acertado que o convênio propriamente dito será publicado na íntegra em Boletim de Serviço Local, bem como informada a aprovação do regulamento. As indicações de Coordenador e Secretário da mesa serão feitas na próxima reuniāo. 2. Planejamento da Ação Fiscal e Produtividade - Após esclarecimentos de ambas as partes, ficou acertado o envio regular e sistemático do Boletim Informativo, que é produzido pela Divisão de Fiscalização da CAF/SP e entregue inclusive aos Gerentes de GRAFs. Ficou aprovada, também, uma reunião conjunta para discutir concepção de gerenciamento, produtividade e propostas concretas. O SINDIFISP/SP perguntou sobre a possibilidade de a negociação ser precedida da suspensão dos efeitos da OS no $113 / 94$. A CAF/SP foi taxativa na negativa, reafirmando que a mesma está com vigor e que deve ser cumprida. 3. Férias do

12 Documento que registra e formaliza o resultados das negociaçöes sobre os itens apresentados nos dois documentos anteriores, subscrito pela CAF/SP e pelo SINDIFISP/SP. 
Servidor - Lei 8.112/90. A justificativa dada pela CAF/SP é que não mais iria aceitar transferências de período de gozo de férias sem motivo justo, pois isto era prática, tornando as exceções em regra. Solicitou, porém, ao Sindicato que sugerisse motivos que justificassem a autorização das transferências para adicionar à regra 'Necessidade do Serviço'. Assunto em andamento. 4. Formação de Grupo de Estudos de Previdência Pública - A CAF/SP demonstrou interesse em participar de Grupo de Estudo e prontificou-se, após estudos preliminares, a convocar o pessoal necessário a formulação de estudos sobre 'Previdência Social Pública' para breve. 5. Plantão Fiscal Negociação de uma padronização mínima - Foi entregue pelo SINDIFISP/SP a tabulação final do questionário sobre Plantão Fiscal e acertado que o SINDIFISP/SP encaminharia as sugestões para padronização mínima para futuras negociações. 6. Reunião Ordinária - assunto extra-pauta. Ficou acordado, em princípio, que as reuniões ordinárias da mesa de negociação seriam nas terceiras terças-feiras de cada mês, sendo que a de outubro será dia 20/10/94.

\section{Carta $\mathrm{n}^{\circ} 329 / 94^{13}$}

Conforme dispóe o regulamento da Mesa de Negociação Permanente, o SINDIFISP/SP encaminha previamente os itens de pauta para discussão:

\section{Assuntos em andamento}

a) Mesa de Negociação Permanente

Indicação dos nomes de Coordenador e Secretário, conforme o disposto no regulamento aprovado na última reunião;

b) Plantão Fiscal

Encaminhamento pelo SINDIFISP/SP de sugestões de padronização mínima do plantão fiscal, Anexo I deste, conforme estabelecido na última reunião de 11/10/94.

c) Transferência de férias para o exercício seguinte

O Sindicato está elaborando, em conjunto com os representantes das GRAFS, sugestōes de casos que sejam de interesse da Instituição e do servidor para autorização, pela CAF, da transferência.

2. Gerências Regionais de Arrecadação e Fiscalizaçăo

a) Avaliação interna sobre o desempenho das gerências regionais. Critérios de escolha e nomeação de gerentes.

13 Documento encaminhado pelo SINDIFISP/SP, em 14/10/94, propondo itens de pauta para a Reunião Ordinária da Mesa de Negociaçâo Permanente. 


\section{Sugestōes/Justificativa}

Considerando a gestão participativa em vigor e os princípios que regem o convênio de Gestão Participativa, em especial o item 6 da cláusula sétima que dispõe entre outros princípios:

"Da globalidade, significando o compromisso de todos os atores da administração previdenciária com o resultado final e não apenas com parte específica dele."

Considerando a cláusula quarta que dispõe:

"O convênio de Gestão Participativa tem por objeto específico dar tratamento e soluçōes aos conflitos que insurgem no processo de trabalho e que afetam, direta ou indiretamente, a qualidade, a eficácia e a produtividade dos serviços."

Considerando, ainda, que o SINDIFISP/SP tem recebido constantemente informações, de alguns de seus representantes junto às GRAFs, dos conflitos existentes em, relação ao gerenciamento;

Sugerimos que se efetue uma avaliação das gerências regionais a partir de pesquisa a ser realizada junto aos $\mathrm{FCPs}$, através de questionário, para que se possa efetivamente avaliar o gerenciamento das GRAFs sob o ponto de vista também de seus subordinados.

Tal sugestão tem por objetivo atestar de um modo mais globalizado as discrepâncias hoje existentes no relacionamento entre Gerentes (chefes) e Fiscais (subordinados), bem como demonstrar que $o$ atual modelo empregado para operacionalizar as decisões superiores influenciam na produtividade e empenho dos executores.

Após o resultado e a depender deste, pretende o SINDIFISP/SP apresentar sugestōes, recebidas de seus representantes junto às GRAFs, de critérios e modelos para escolha dos gerentes regionais, a partir de seus subordinados que terão o compromisso e a responsabilidade de apoiá-los.

Esta iniciativa visa a abolir do seio de nossa categoria as escolhas políticas, nem sempre corretas, dos gerentes das GRAFs prejudicando sobremaneira nossa Instituição.

\section{b) Distribuição de Carga de Trabalho e Diárias - Transparência}

\section{Justificativa}

Apesar de a questão em pauta ser um problema de gerenciamento, que poderá ser confirmado com a realização da avaliação proposta no item (a), e a escolha da carga de trabalho estar vinculada às diretrizes programadas pelos escalóes superiores, o que vem ocorrendo na prática, em diversas GRAFs, é a total falta de critério na distribuição da carga. Tal procedimento gera descontentamento dos FCPs, que se sentem prejudicados inclusive para obtenção de sua produtividade mínima.

Há GRAFs em que os Supervisores de Equipe de Fiscalização não são os responsáveis pela seleção e distribuição das cargas e das diárias aos FCPs, contrariando até mesmo a ordem de serviço do INSS.

c) Empresas Denunciadas por Sonegação e Evasão - Prioridade de Fiscalização 


\section{Justificativa/Sugestão}

Temos sido informados, por representantes de algumas GRAFs, que nem sempre é dada prioridade à fiscalização dessas empresas. Assim, sugerimos que seja determinado às Gerências que as mesmas entrem na programaçăo do mês seguinte ao da denúncia como prioridade e que a CAF/SP seja informada imediatamente sobre a denúncia e o resultado obtido pela fiscalização.

3. Realização sistemática de cursos, treinamentos e reciclagem, que possam ser freqüentados por todo o contingente fiscal e ministrados por instrutores altamente qualificados.

\section{Justificativa}

O SINDIFISP/SP tem recebido solicitaçóes constantes da categoria com relação à realização, pela $\mathrm{CAF} / \mathrm{SP}$, de treinamento, cursos e reciclagem de maneira global e sistemática.

Temos tido esporadicamente, com exceção do Curso de Auto de Infração, cursos-relâmpago, sem que haja continuidade e difusão para todo o contingente fiscal. Participam desses cursos poucos fiscais. Ademais, na maioria das vezes, não são escolhidos de maneira acertada.

Determinadas áreas de interesse, tanto da Instituição quanto da própria classe, não têm tido a devida atenção ou os instrutores não têm a melhor qualificação, segundo avaliação de Fiscais que freqüentaram determinados cursos.

Propomos a discussão, inclusive com o Setor de Recursos Humanos de São Paulo e o Setor de Treinamento, para implantação de um cronograma de atividades que contemple os assuntos de maior interesse e para todo o contingente fiscal, visando o aprimoramento do desempenho da fiscalização.

4. Acesso aos programas de informática do INSS. Distribuição de cópia em disquetes aos FCPs.

\section{Justificativa}

Como é prática em outros estados, faz-se necessário que os fiscais tenham pleno acesso aos programas de informática disponíveis na Instituiçăo. Tal solicitação visa a dar maior agilidade nos trabalhos desempenhados pela fiscalização.

5. Gestões junto aos escalóes superiores. Solicitação de apoio e empenho da CAF/SP.

O SINDIFISP/SP solicita apoio eficaz junto aos escalóes superiores para os seguintes pleitos dos fiscais:

a) aquisição, pela Instituição, de notebook a ser distribuído aos Fiscais, como instrumento de trabalho adequado e compatível com os usados pelas empresas que são fiscalizadas. Tal solicitação prende-se à promessa do então Diretor de Arrecadação e Fiscalização do INSS, Sr. Moretti, que já estariam previstos no orçamento, ou

b) subsídio e/ou financiamento, a todos os Fiscais, de tal equipamento de informática pelas mesmas justificativas; 
c) aumento imediato do auxílio-transporte conforme estudos já encaminhados, pela FENAFISP, à DAF e ao Sr. Ministro;

d) abertura imediata de concurso público para Fiscais de Contribuições Previdenciárias e Agentes Administrativos, uma vez que há quase dez anos não se realiza tal concurso. A falta de pessoal vem contribuindo para a má qualidade dos serviços prestados pela Instituição.

Sem mais, subscrevemo-nos, com nossas cordiais saudaçōes.

\section{Referência: Convênio do Sistema de Gestão Participativa ${ }^{14}$}

\section{Assuntos em andamento}

a) Mesa de Negociação Permanente

CAF - Indicação do FCP Douglas Gerson Braga para desempenhar as atribuições de Coordenador dos trabalhos da Mesa de Participação Permanente.

b) Plantão Fiscal

CAF - A Divisão de Fiscalização prepara documento analítico, considerando também as sugestōes do SINDIFISP/SP sobre o assunto. Será apresentado brevemente à Mesa de Participação Permanente para discussão conjunta.

c) Transferência de férias para o exercício seguinte

CAF - No aguardo das sugestōes a serem apresentadas pelo SINDIFISP/SP.

2. Gerências regionais de arrecadação e fiscalização

a) CAF - Com o objetivo de melhorar a qualidade, a produtividade e a eficácia dos serviços, a Administração tem interesse no maior envolvimento e na maior participação dos fiscais e dos servidores administrativos nas avaliações de desempenho das GRAFs.

A CAF sugere, para tanto, a aplicação de um método de 'Avaliação Integrada', apoiada em diagnóstico, a ser elaborado através da formulação de quesitos, escolhidos de comum acordo, da seguinte forma:

1. O público-alvo seria distribuído em três grupos, a saber: Grupo de Servidores Administrativos, Grupo de FCPs em trabalho de rua e Grupo de FCPs em trabalho interno.

II . Os quesitos seriam divididos em duas categorias: voltados para auto-avaliação do grupo e para avaliação dos demais grupos.

III. Quanto ao seu caráter, os quesitos atenderiam a duas ordens de preocupaçōes, saber:

- de caráter subjetivo, visando a diagnosticar a qualidade das relaçôes interpessoais em nível de motivação, a avaliação pessoal da capacitação profissional, as expectativas profissionais, os aspectos positivos e negativos do trabalho na GRAF, as dificuldades para o desempenho das funçōes etc., além de coletar sugestões para o aperfeiçoamento destas relaçôes.

14 Documento encaminhado pela CAF/INSS/SP, à Coordenação da Mesa de Participaçáo Permanente, em $27 / 10 / 94$, em resposta às questōes apresentadas pelo sindicato. 
- de caráter objetivo, visando a diagnosticar aspectos da eficácia, da produção e do funcionamento estrutural da GRAF, e colher sugestōes de aperfeiçoamento.

Este método permite elaboração de diagnóstico mais preciso e próximo da realidade que se deseja diagnosticar, permitindo uma visăo mais abrangente e detaIhada das GRAFs.

Praticada com certa periodicidade, a Avaliação Integrada poderá constituir importante subsídio para os procedimentos que a Administração já adota com esta finalidade. Deverá também servir como mais um orientador da atuação sindical, na busca de soluções para os problemas concretos que afligem a categoria. Por fim, é certo que sua adoção será de grande utilidade para a atuação das Mesas de Participação Conjunta que deverăo funcionar nas GRAFs.

Para concluir este tópico, face às consideraçōes tecidas pelo SINDIFISP/SP, a CAF informa que os critérios que hoje comandam a nomeação para cargos de gerência ou de confiança da Administração são estritamente de caráter profissional, fundados na competência, na moralidade e no compromisso com os interesses da Administração.

b) Distribuição de carga de trabalho - diárias - transferência

CAF - Contemplado no item (a).

A Divisão de Fiscalizaçăo realiza estudos para a elaboração de novo modelo de distribuição da carga e de divisão do trabalho. Estes estudos serăo apresentados e discutidos na Mesa de Participação.

c) Empresas denunciadas

CAF - Quando a denúncia é encaminhada à Divisão de Fiscalização, determina-se investigaçăo prévia da mesma e apuração pela GRAF competente ou pela própria Divisão, com prazo de até 60 (sessenta) dias para retorno, cobrado com rigor.

Quando a denúncia é encaminhada diretamente à GRAF, procura-se coadunar a necessidade de cumprimento do planejamento trimestral, observando as diretrizes de prioridade, com a apuração da denúncia. Raramente a denúncia deixa de ser apurada em prazo superior a 90 (noventa) dias. É preciso considerar, ainda, que a apuração de uma denúncia não desencadeia, necessariamente a fiscalização da empresa. Por cautela, para evitar generalizações, muitas vezes infundadas, este assunto poderia ser tratado de forma mais concreta e objetiva, analisando-se caso a caso. Pode, também, ser contemplado nos encaminhamentos do item (a).

\section{Cursos e treinamentos}

CAF - Na linha de defesa da qualidade, da produtividade e da eficácia dos trabalhos de arrecadação e fiscalização, a Administração tem interesse - e sempre tem demonstrado isto - na melhor qualificação e preparo de seus quadros.

Lembramos que, em meados do corrente ano, a CAF organizou e encaminhou ao RH inúmeras sugestões colhidas junto às GRAFs, à APAFISP e ao SINDIFISP/SP para planejamento de cursos e treinamentos referentes ao ano de 1995.

$\mathrm{ACAF}$ tem interesse na elaboração conjunta de um cronograma de treinamento para o ano de 1995. 
Informa, ainda, que para 1994 serão ministrados três importantes treinamentos, a saber: o Programa de Informatizaçăo da Ação Fiscal (PIAF), direcionado aos fiscais que dispõem de equipamentos; o formação Analistas, preparatório para o desempenho desta nova função e o Formação Supenvisores, voltado aos fiscais que desempenham estas tarefas.

\section{Acesso aos programas de informática}

CAF - É necessário que se mencionem quais programas se deseja acessar, para que a Administração avalie os aspectos de interesse dos servidores e da instituição, frente aos riscos que o acesso possa acarretar ao sistema.

É oportuno lembrar que cuidados mínimos quanto à utilização de equipamentos não têm sido observados em muitas GRAFs.

Também é preciso não esquecer que a introdução de equipamentos ou de novos procedimentos na realização do trabalho importa absorção de custos com treinamento, manutenção e supervisão de serviços que exigem planejamento e que, nem sempre a Previdência está preparada para arcar, de imediato.

\section{Gestões junto aos escalóes superiores}

a) b) Notebook / subsídio / financiamento

CAF - É do nosso conhecimento que a Administração superior providencia a aquisição de 450 equipamentos, ou seja, um para cada equipe fiscal. Também é do nosso conhecimento que a ANFIP negociou linha de crédito especial aos FCPs, junto ao BNDES, para financiamento de compra do equipamento, diretamente por parte dos fiscais.

Dada a complexidade do assunto que envolve, por exemplo, a política de prioridades da Previdência, os custos de aquisição, de manutenção e operacionais do sistema , inclusive seu saturamento e obsolescência etc., e face às notórias dificuldades financeiras da Previdência Social para a aquisição de equipamentos individuais a todos os fiscais, seria oportuno discutir fórmulas alternativas, a título de sugestão, visando a compor solução efetivas para esta questão.

c) Auxílio Transporte

CAF - Este item também merece aprofundamento. As necessidades e as despesas efetuadas com transporte variam sensivelmente em função do porte das cidades e das regióes, é possível que haja situações em que o valor do auxílio transporte esteja aquém do necessário. Contudo esta constatação não se aplica a todas as regiōes e cidades, indistintamente.

d) Concurso Público

CAF - É conhecida a posição da CAF em defesa da realização de Concurso Público para admissão de FCPs e de servidores administrativos. Contudo, esta defesa vem sempre acompanhada do alerta de que a ampliação do quadro funcional, por si só, não resolve os principais problemas que a Previdência enfrenta. Faz-se necessário engendrar uma nova cultura de serviços públicos, apoiada na redefinição do papel do 
Estado brasileiro, em busca da efetivação dos direitos essenciais da cidadania que determina a readequação do aparelho administrativo e do seu quadro funcional.

Espera-se que o roteiro apresentado neste tópico, com todas as suas limitações, sirva como estímulo e visualização de possibilidades aos diversos segmentos interessados nas questões relacionadas aos serviços públicos. A realidade é bem mais dinâmica e complexa do que a que se pôde aprisionar nestas páginas. Novas experiências certamente encontrarão rumo próprio e conseguirão atingir patamares de qualidade e de eficiência superiores aos verificados nas experiências aqui sistematizadas. $O$ importante é que a sociedade, por meio dos canais que cria, não abra mão de desenvolver projetos para reformular o papel do Estado e da sua administração, colocando-os efetivamente a serviço da cidadania.

A grande preocupação das sugestôes contidas no Roteiro em Seis Passos consistiu em envolver segmentos e dividir responsabilidades pela viabilizaçăo das mudanças desejadas. Isto poderá ser obtido por intermédio da criação de mecanismos que, pressupondo a natureza conflituosa das relações nesse setor, permitam a participação direta dos diversos atores, o controle social sobre seus atos e a solução negociada desses conflitos, em torno de um objetivo comum: prestar e atender, com qualidade, eficácia e democracia, os serviços e as demandas da cidadania, em seu benefício, e em benefício da dignidade da pessoa humana. 


\section{Análises de Modelos de Gestão}

As experiências abordadas até esta etapa serão, agora, objeto de considerações políticas. Aqui, a preocupação central será reproduzir e apresentar novos e antigos estudos, relatos, avaliaçōes, investigaçōes e análises de caráter político a respeito desses assuntos. Também serăo transcritas experiências legislativas, ainda não sistematizadas até o momento. Portanto, o tratamento técnico e jurídico e seus aspectos práticos, que mereceram prioridade nos capítulos anteriores, cedem lugar para abordagens conceituais mais amplas, especialmente quanto à sua eficiência e quanto às oportunidades políticas de se instituir modelos de gestão desse tipo.

É possível, por exemplo, conhecer o contexto político que produziu experiências bem sucedidas, como a do IAMSPE, ainda que a forma contratualista aplicada esteja, em nosso entendimento, superada. E também conhecer os fundamentos da proposta petista para a Prefeitura Municipal de São Paulo. Apreender - ou tentar apreender as razões que motivaram o insucesso dessa experiência, ainda que seus protagonistas integrassem um mesmo arco político e ideológico.

O Sistema de Gestão Participativa do INSS e o modelo pioneiro de 'Avaliação Integrada' dos seus servidores, experiência premiada pela ENAP, MARE e ANASPS, também merecem destaque nesta parte do trabalho, juntamente com a exposição da experiência produzida no Município de Campinas.

Merecem consideraçōes à parte as experiências de regulação legislativa de sistemas permanentes de negociação coletiva no setor público. São procedimentos que se diferenciaram dos demais, principalmente em razão da participação de atores diversos daqueles freqüentemente envolvidos. Não deve ser difícil notar que as dificuldades relacionadas ao tratamento legislativo dessas questōes são bem maiores. As poucas iniciativas que se efetivaram nessa esfera comprovam esta assertiva. Entre as explicações para o aprofundamento dessas dificuldades, destacam-se a ampliação do rol de participantes nas discussões das iniciativas a serem adotadas e a pluralidade política e ideológica que caracteriza o Poder Legislativo e as instituiçóes colegiadas, tais como os conselhos de representantes. Essas condiçóes demandam exaustivo processo de negociação e estiveram presentes nas experiências sistematizadas. 
Em conseqüência, no campo legislativo não há muito a relatar, o que não reduz, ao contrário, torna ainda mais relevante a reprodução de experiências desse tipo, arroladas neste capítulo.

A instituição de modelos de gestăo, como os sugeridos neste livro, depende da adesão dos servidores públicos e da participação de entidades sindicais. No meio sindical há muita polêmica e - pior ainda - muita desinformação sobre este assunto. Os estudos que iniciam este capítulo buscam dirimir algumas dúvidas e estabelecer certos parâmetros de discussão para o movimento sindical.

\subsection{AOS SINDICATOS COMBATIVOS: UMA CONSIDERAÇÃO POLÍTICA}

Entendemos por sindicalismo combativo a linha sindical pautada pelo caráter eminentemente conflituoso das relações sociais, pela democracia sindical, pela combinação de interesses setoriais com a defesa de interesses gerais da classe trabalhadora, pela composição de elementos ideológicos com elementos pragmáticos de luta, pela aplicação de elementos pertinentes ao campo da correlação de forças, pela organização dos trabalhadores, a partir dos seus locais de trabalho, pelo envolvimento, conscientização e mobilizaçăo dos trabalhadores, pela articulação das lutas econômicas e imediatas com as lutas de caráter mais geral e de médio e longo prazos, e pela luta para a conquista plena da cidadania aos trabahhadores.

Tivemos a oportunidade de vivenciar parte da construção desse sindicalismo combativo no Brasil, a partir da década de 70 . A luta das oposições sindicais, a fundação da CUT, a participação dos trabalhadores na Assembléia Nacional Constituinte e a organização sindical dos senvidores públicos são exemplos dessa construção. Integramos, por dois períodos, de 1989 a 1993, a representação dos trabalhadores no Conselho Curador de FGTS, por indicação da CUT.

Foi por intermédio desta última experiência, em especial, que pudemos compreender, com maior clareza, as interseções e as dificuldades que permeiam as relações e os interesses dos trabalhadores do setor privado e dos servidores públicos. E de ambos com os movimentos sociais populares. Dificuldades que abarcam, principalmente, questōes de caráter ideológico, situadas no campo conceitual. Especificamente no que se refere à concepção e à redefinação do caráter do movimento e do papel da organização sindical, no contexto mais amplo da discussão sobre o papel do Estado brasileiro.

Contudo, ainda que com muitas dificuldades e divergências conceituais, o movimento sindical seguiu incorporando, no patamar das suas prioridades estratégicas, as reivindicações de cidadania para a classe trabalhadora. Diante disto, oportunidades que reforcem, na prática, esta direção, não podem ser desperdiçadas. A participação da organização sindical em Conselhos e em órgão colegiados e a sua articulações com os movimentos sociais populares são exemplos dessas oportunidades.

Merece, pois, ênfase especial para os objetivos ora perseguidos as experiências e o redesenho de estratégias que permitam a articulação dos trabalhadores do setor 
privado com os do setor público. Ambos os segmentos, aliados aos movimentos sociais, poderão defender, com maior eficiência, o funcionamento qualificado dos serviços públicos e o atendimento eficaz às demandas da cidadania.

Para que isto ocorra, o planejamento e o modo de execuçăo dos serviços públicos e, conseqüentemente, suas relações de emprego e de trabalho, devem ser objeto de preocupação de todos os segmentos interessados nesta questão e não apenas dos internamente envolvidos. Sendo esta premissa verdadeira, faz-se necessário formular e participar de alternativas concretas que viabilizem a consecução destes objetivos.

As experiências arroladas neste nosso trabalho estiveram contidas no contexto descrito. Como também é nesse contexto que se insere a atual proposta de desenvolvimento e de qualificação das relações de emprego, de trabalho e dos serviços prestados na órbita da Seguridade Social.

Sobre os processos desenvolvidos com a nossa participação, direcionados para os objetivos apontados, existem análises que reforçam os acertos e outras que apontam as deficiências e as limitações dessas experiências. Dependendo, pois, do enfoque político dos seus dirigentes, os sistemas de negociação e de participação no setor público são vistos de forma diferenciada pelos sindicatos. Entretanto, independentemente das diversas visōes que permeiam o movimento sindical, há incongruências que o levam, freqüentemente, a impasses cruciais. Impasses que colocam trabalhadores uns contra outros. Entender e superar essas incongruências é vital para o desenvolvimento das lutas sociais no Brasil e para a transformação do Estado em instrumento a favor da cidadania.

O distanciamento dos trabalhadores do setor privado e das suas entidades sindicais sobre temas que condicionam o exercício da cidadania acarreta enorme sobrecarga e isolamento às demandas dos trabalhadores do setor público. É comum um operário indignar-se com greves do setor público e apoiar propostas de 'enxugamento' do aparelho administrativo.

Estabelece-se, assim, um círculo vicioso: aniquilados em suas condições básicas de sobrevivência, os servidores públicos partem para as greves. Com elas, é verdade, causam sérios desgastes políticos à imagem dos administradores. Mas os assalariados e as camadas mais pobres da população, que constituem a enorme massa de usuários dos serviços públicos, por não disporem de outras alternativas, săo extremamente prejudicados. Em razão disto, distanciam-se, ainda mais, das questōes referentes aos serviços e aos servidores públicos.

É justo, contudo, pedir a um professor, esmagado pelo salário que recebe, que deixe de lutar ou de fazer greve para não prejudicar seu companheiro do setor privado? Especialmente quando este companheiro demonstra pouco ou nenhum interesse com o que acontece no setor público?

Por tais razōes, e para romper com este círculo vicioso, faz-se necessário estabelecer processos diferenciados de apreciação de conflitos do trabalho no setor público. Por exemplo, processos que se iniciem por intermédio do envolvimento, da organização e da articulação prévia entre os próprios trabalhadores (público e privado), dos quais possam ser extraídas pautas comuns, defendidas em campanhas conjuntas e articuladas. E onde os trabalhadores do setor privado, por intermédio de entidades 
e de organismos próprios (Conselhos, por exemplo), interfiram no planejamento, na forma de execução dos senviços e na qualificação das relaçóes de trabalho no setor público. As greves, decorrentes de processos como o exemplificado anteriormente, com certeza passariam a ocorrer com menor freqüência e seriam absorvidas, política e praticamente, de maneira bem diferente pela sociedade.

Trata-se, pois, de encetar estratégias de consolidação de aliança permanente entre os trabalhadores dos dois segmentos e a sociedade civil, em defesa dos interesses e das condições essenciais ao exercício da cidadania.

Outra não foi a estratégia adotada na condução dos trabalhos no Conselho Curador do FGTS, considerada correta pelos movimentos sindical e social de moradia. Articulamos uma atuação unitária e combinada das três centrais sindicais, do movimento popular de moradia, das entidades ligadas ao setor de saneamento básico e infra-estrutura urbana e dos bancários da Caixa Econômica Federal, órgāo gestor do Fundo.

Aceitando-se como correta esta estratégia e como verdadeiras estas premissas, há providências imediatas a serem adotadas. Providências de responsabilidade dos diversos atores envolvidos. Assim, o administrador público, comprometido com o 'Estado-cidadão', é co-responsável pela adoção de medidas para desenvolver uma nova concepçăo de gerenciamento dos serviços e das relações de trabalho no setor. Esta responsabilidade é também dos sindicatos dos servidores públicos. Aos sindicatos dos trabalhadores do setor privado cabe liderar a participaçăo da sociedade civil neste processo. Cabe-thes incluir açōes voltadas para sua articulaçăo com o setor público, nos mesmos patamares de prioridade que dedicam às suas campanhas salariais corporativas. Somente uma ação combinada deste porte será capaz de engendrar uma nova cultura de realização dos serviços públicos em nosso país.

É neste contexto que se coloca a participação ou a reivindicação sindical do setor público de promover projetos para alterar e desenvolver o quadro atual de relações de emprego e de trabalho. Sistemas como os relatados neste livro satisfazem plenamente aos interesses de fortalecimento do sindicalismo combativo, também no setor público, uma vez que pressupōem e efetivam o princípio sagrado da organização dos trabalhadores em seus locais de trabalho, imprescindivel à consecução da linha sindical combativa.

Por fim, é sempre bom lembrar que negociar é da essência da organização sindical. Negociação é meio de explicitação de conflitos. Pressupõe, portanto, o reconhecimento e a legitimidade da sua existência e a possibilidade legal da defesa de interesses específicos. Explicitação de conflito não significa, necessariamente, a sua composição ou conciliação mas, sobretudo, a sua apreciação prévia no contexto da correlação de forças do movimento e da sociedade.

Analisando a experiência apoiada pela CUT, pelo Governo do Estado de São Paulo e pelo Ministério do Trabalho, desenvolvida no IAMSPE, a partir de 1988, e que continua vigindo, em artigo publicado nos Cadernos da CUT: Jurídico e Relações Sindicais (v.3, jan.1990), registramos o seguinte, a respeito do assunto: 
Quer no setor privado, quer no setor público, é evidente que a adoção de um sistema de solução de conflitos embute a questão da correlação de forças. $O$ resultado do embate entre as forças interessadas indicará mecanismos de apreciação e de prevençāo, diagnósticos e tratamentos adequados. Ou seja, a imposição de determinados mecanismos de apreciação e de resolução de conflitos, que fortaleçam à determinada concepção política, depende da força da parte que os pleiteia e da sua capacidade de viabilizar sua estratégia.

A adoção do processo permanente de negociação coletiva no IAMSPE traduz o sentido de conquista das entidades sindicais. Situa a resolução dos confitos no campo da correlaçăo de forças, tomando-os mais permeáveis ao sistema de pressão. Estabelece mecanismos em que atuam todas as partes interessadas. Contrapöe instrumentos coletivos a instrumentos individualizados. Soluçōes negociadas, segundo os interesses das partes, à soluções autoritárias, administrativas ou judiciais.

A implantação deste projeto implica, de imediato, reconhecimento de legitimidade e de força, na medida em que introduz regras de interesse primordial dos trabalhadores, quer da comunidade interna, quer da comunidade de usuários. Regras como garantias de exercícios das liberdades sindicais, liberação de dirigentes e de funcionários, mecanismos de formalização de direitos etc.

$\hat{E}$ neste sentido que o projeto de negociação coletiva, alinhavado pelo sindicalismo cutista, a partir da década de setenta, é expressão concreta da luta e não da conciliaçăo de classes. Implica legitimidade e reconhecimento. Supõe mobilização e organizaçăo no local de trabalho. Promove a ampliação do espaço democrático de atuação e o fortalecimento organizativo. Estimula o debate ideológico e gera acúmulo de forças no campo político para a efetivaçăo de novas conquistas da classe trabalhadora.

Veja-se, ainda, em que contexto político foi instalado o processo de negociação do IAMSPE, relatado no mesmo artigo.

A administraçäo anterior (do lAMSPE) contava com a simpatia das entidades sindicais e de lideranças locais (alguns ocupavam cargo de direção). A atual administraçāo foi nomeada pelo Secretário de Saúde, em fevereiro de 88, em meio a um movimento grevista que durava cerca de vinte dias. Foi recebida como interventora e declarada inimiga número um pelas entidades sindicais.

A comunidade detém larga tradição de lutas. As principais entidades sindicais que atuam no lAMSPE, cutistas de primeira hora, são as seguintes: Associação dos Funcionários (AfiamSPE), Associaçăo dos Médicos (AMIAMSPE), Sindicato dos Médicos do Estado de São Paulo e, mais recentemente, o Sindicato dos Trabalhadores na Saúde, ao qual a AFIAMSPE vinculou-se organicamente. Há, ainda, a Associação das Enfermeiras e outras entidades menores, não cutistas.

Os usuários, através de suas entidades sindicais, boa parte cutistas (APEOSP, ADUSP, etc.), atuam dentro do IAMSPE por intermédio da Comissão Consultiva Mista, da qual participam juntamente com as entidades sindicais internas e a administraçāo do Instituto...

O grau de conflitos, já bastante elevado em atividades dessa natureza e fortemente agravado em virtude das condiçöes descritas, afeta, sensivelmente, a qualidade dos serviços prestados aos usuários. Conseqüentemente, estes são os maiores interessados e beneficiários diretos da redução e da composição dos conflitos. 
É interessante conhecer a posição oficial da CUT, manifestada em um dos raros momentos de consenso da sua direção nacional e das diversas tendências políticas que nela coabitam, através da proposta encaminhada ao Governo Itamar Franco, em dezembro de 1992, sobre mudanças nas relações de trabalho dos setores privado e público, intitulada Sistema Democrático de Relaçōes de Trabalho: uma proposta para a adoção da ética, da transparência e da democracia nas relaçōes de trabalho, da qual destacam-se as seguintes consideraçōes:

A instituição de mecanismos de participação e de controle social sobre a formulação de políticas e gestão dos recursos públicos deve ser acompanhada por profunda revisāo de conceitos e de transformaçōes estruturais na forma de conceber, administrar e executar os serviços públicos.

Os princípios autoritários que regem as relaçōes de trabalho no setor privado estāo presentes, sob outras formas, nas relaçōes de trabalho do setor público.

$A$ adoção de um novo sistema que permita a explicitação e o tratamento democrático dos conflitos do trabalho é essencial para se garantir maior eficácia, melhor desempenho e, portanto, melhor qualidade dos serviços.

Esta qualidade, para ser alcançada, exige o resgate da dignidade do trabalho neste setor, o que implica reconhecer e alterar as relaçöes de poder estabelecidas autoritariamente e as distorçöes administrativas e salariais incontestáveis.

A CUT propõe a instituição de mecanismos que reúnam os diversos segmentos diretamente interessados na questão, com a criação do Conselho Nacional de Administraçăo Pública, a ser integrado por representantes do Executivo, do Legislativo, das entidades dos servidores públicos, das centrais sindicais e da sociedade civil.

Propōe também a adoçāo, com as adequaçōes que se fizerem necessárias, do Sistema Permanente de Negociação Coletiva de Trabalho para o setor público, buscando, ao dar aplicabilidade aos principios democratizantes, assegurar a ética, a transparência e o compromisso de todos com a busca permanente da qualidade dos serviços prestados à populaçāo.

Năo há dúvida, pois, de que a adoção de sistemas formais de negociação e de participação para o desenvolvimento das relaçōes de trabalho no setor público deve ser entendida e creditada como conquista do movimento sindical combativo e da sociedade. Tais instrumentos asseguram a prática permanente da apreciação dos conflitos, por meio da aplicação de regras claras, prévia e consensualmente estabelecidas. Servem à organização dos trabalhadores nos locais de trabalho, motivam sua mobilização e consolidam a aliança estratégica dos trabalhadores de ambos os setores, público e privado, com os demais segmentos da sociedade.

Convênios dessa natureza constituem a principal contribuição para o consecução dos objetivos-fim da Administração Pública que devem ser: prestar e atender, com qualidade, eficácia e democracia, os serviços e as demandas da cidadania, em seu benefício e em benefício da dignidade da pessoa humana. 


\subsection{ASSUNTOS RELACIONADOS À PREFEITURA DO MUNICÍPIO DE SÃO PAULO}

\section{Comentários sobre uma Experiência Incompleta}

A despeito do excelente material teórico produzido e do aprendizado que proporcionou aos diversos participantes, o projeto de democratização administrativa das relações de trabalho e de qualificação dos serviços públicos municipais que se estendeu por três anos na Prefeitura do Município de São Paulo não alcançou os resultados pretendidos. A conhecida afinidade política existente entre os interlocutores - a gestão administrativa municipal era do Partido dos Trabalhadores (PT) e as entidades sindicais participantes, na sua maioria, eram filiadas à CUT - não foi suficiente para coroar de êxito a proposta.

Houve consenso suficiente para a celebração de Protocolo de Intenções e até mesmo para garantir o envio de Projeto de Lei à Câmara Municipal da cidade. Contudo, as propostas não evoluíram para a criação de uma ferramenta de intervenção prática e eficiente e o que se viu foi um período marcado pela confrontação permanente entre os diversos segmentos envolvidos, com greves longas e campanhas radicalizadas, mais até que outras ocorridas em gestōes anteriores e posteriores à gestão administrativa do PT.

Desnecessário dizer que o desgaste político foi enorme e as conseqüências negativas para todos. Como é sabido, confrontos permanentes, com greves prolongadas, prejudicam e irritam a população. Acarretam, portanto, prejuízos à ação e à imagem do administrador público, especialmente quando envolvem segmentos políticos afins, ainda que dirigentes da CUT e o PT não medissem esforços para promover a implantação do projeto.

A responsabilidade pela não efetivação do Sistema Permanente de Negociação Coletiva de Trabalho na Prefeitura do Município de São Paulo e pela deterioração das suas relações de emprego pode ser atribuída aos dois lados.

À Administração que, por intermédio de alguns segmentos, interpunha obstáculos, quase sempre de natureza técnica, para dificultar a implantação do projeto político, ainda que tal projeto tivesse sido aprovado, por consenso, pela equipe da Prefeita Luiza Erundina. Na verdade, as dificuldades técnicas interpostas escondiam um mal disfarçado apego pela concentração de poder, praticado por certos setores do Governo Municipal. Por exemplo: houve ocasião em que se reuniam Secretário da Administração, dirigentes sindicais e assessores para implantação do Sistema de Negociação Coletiva, com pauta para discutir, inclusive, índices de reajuste salarial. No curso da reunião os participantes tomam conhecimento, pela imprensa, que outra Secretaria anunciava índices e posições sobre o reajuste em discussão, desautorizando, assim, o Secretário da Administração e o sistema de relações de trabalho que se pretendia instituir.

Já os sindicatos não bancavam seriamente o projeto por receio das acusaçôes que lhes eram desferidas por adversários internos, de cooptação política, optando, muitas vezes, pela radicalização e confronto para marcar posiçôes.

Assim, ambas as partes faziam um discurso consensual favorável à adoção do modelo proposto para regular suas relaçōes, mas, na prática, cuidavam de inviabilizá-lo. 
Na Companhia Municipal de Transportes Coletivos (CMTC) ocorreram confrontos permanentes, greves longas e movimentos extremamente radicalizados. Para se ter uma idéia do nível de confronto que se estabeleceu, a Prefeita Luiza Erundina era chamada, de forma depreciativa, nos boletins da entidade, de 'Jânio de saias', numa alusão ao ex-prefeito da cidade, Jânio Quadros, ferrenho adversário político do PT.

Mesmo com os esforços concentrados e empenho pessoal da Prefeita, o setor de transportes coletivos ficou muito aquém dos índices de desempenho aferidos nas pesquisas de opinião que avaliaram a administração municipal petista.

Na gestão seguinte, uma das primeiras providências do Prefeito Paulo Maluf foi privatizar o sistema de transportes públicos municipais, extinguir a CMTC e demitir milhares de trabalhadores. O Sindicato dos Condutores ficou isolado em sua luta contra a privatização e a demissăo em massa dos seus representados. A população sofre ainda mais com o atual sistema de transportes públicos da cidade.

Excetuando-se as empresas de transportes e as concepções privativistas, alguém mais ganhou com o confronto administração petista versus entidades sindicais?

De um modo geral, pode-se dizer que a implantação de novos modelos de gestão - calcados na desconcentração de poder, na negociação de interesses e de conflitos que até entăo eram considerados de alçada exclusiva do administrador, e na participação propositiva das entidades sindicais e de usuários - gera incompreensões e resistências no momento da sua efetivação.

Em todas as experiências de que participamos ocorreram dificuldades desse tipo, em maior ou menor grau, que custaram um longo período de discussões, estudos, seminários e debates para serem superadas.

Essa incompreensão geralmente é motivada por razões de ordem cultural. Resulta, no caso das entidades sindicais, da cultura de oposição sistemática das associaçóes combativas de servidores públicos, adquirida no período de combate ao regime autoritário, em que, por princípio, era negado qualquer tipo de participação ou de diálogo com administradores nomeados pela ditadura militar. Ressalte-se, contudo que, mesmo assim, ocorriam negociações legítimas sobre reivindicações específicas, durante campanhas salariais, pois esta sempre foi uma atribuiçăo intrínseca das entidades de caráter sindical.

O receio de assumir uma prática diferente da habitual, não dominada totalmente por dirigentes e assessores sindicais, gera insegurança e estimula a acomodação em torno das práticas convencionais.

Esse receio também ocorre do lado dos administradores. Acreditamos que as dificuldades da administração em aceitar a troca de poder concentrado por um mecanismo que desconcentre e estabeleça negociações em torno do objeto desse poder, com as partes interessadas, também seja fruto da cultura gerada por um modelo de Estado historicamente autoritário.

Assim, năo raro, encontramos 'pareceres técnicos' da administração, negando a participação e o controle social sobre a ação administrativa. E nos deparamos com posicionamentos de entidades sindicais que confundem a negociação e a participação crítica, combativa e também propositiva com cooptação política. 
Pior: é freqüente as partes acreditarem estar 'prestando favor' à outra, por sujeitaremse a um modelo de negociaçáo que visa a obter melhorias e benefícios para a cidadania. Parecem estar sempre se desculpando por participarem de um sistema institucional e transparente de negociação, preferindo, muitas vezes, a clássica negociação de bastidores.

No caso da Prefeitura de São Paulo, reações e incompreensões deste tipo impediram que o modelo de gestão democrática fosse completamente introduzido, ainda que as partes integrassem um mesmo arco ideológico e político e o clima inicial para a instituição do projeto fosse bastante cordial.

No IAMSPE, onde a negociação iniciou-se entre partes que detinham posturas políticas e ideológicas opostas - Governo Orestes Quércia e PMDB, por um lado, e sindicatos da CUT e lideranças organicamente ligadas ao PT, por outro - o clima inicial era de confronto aberto. Houve, inclusive, tomada física do prédio da Superintendência por parte dos dirigentes sindicais, em protesto contra a posse dos administradores. Mesmo assim, o Sistema de Negociação Permanente, instalado em 1989, prosperou e perdura até hoje (veja protocolos da Mesa de Negociaçáo celebrados em 1995, apresentados neste livro).

A análise, o debate e a compreensão dos elementos que motivaram o êxito de uma experiência, ainda que desenvolvida em ambiente extremamente hostil e em condiçōes iniciais adversas, e provocaram o insucesso em outra, cujas condiçóes pareciam favoráveis para o seu desenvolvimento, tornam-se fundamentais para os rumos a serem dados a projetos desse tipo.

Analisando alguns desses elementos, percebe-se que a discussão em torno do papel do Estado, e por conseqüência da forma de gerenciá-lo, exigirá revisões e redefinições de papéis para o conjunto dos atores sociais. A organização sindical não está imune a esta clara necessidade. No entanto, esta discussão, no meio sindical, ainda é muito incipiente, e encontra grande resistência.

A reforma do Estado para transformá-lo em Estado Democrático de Direito, nos termos exigidos expressamente no primeiro artigo da Constituição Federal, também exigirá a releitura do Direito Administrativo. Tal releitura deve proceder a sua adaptação aos princípios democratizantes requeridos pela Carta Magna. Mas há, também neste campo, enorme resistência. Administradores e doutrinadores parecem dar preferência às interpretações restritivas dos conceitos democratizantes introduzidos constitucionalmente, a promover a crítica do Direito Administrativo, à luz desses novos princípios.

Olhando apenas para os aspectos da questão em que se encontram envolvidas organizaçōes sindicais dos trabalhadores e a administração pública, percebe-se uma clara omissão, no primeiro caso, e uma deturpação, no segundo, frente às demandas da democratização do Estado e ao projeto de sociedade requeridos.

O Estado, como provedor de regras garantidoras de um maior equilíbrio nas relaçōes de poder estabelecidas na sociedade, e garantidor das condições essenciais ao exercício da cidadania, deve dispor de instrumentos ágeis para se viabilizar neste papel. O aparelho administrativo e o pessoal encarregado da execução dos seus serviços devem estar adequados e preparados para o exercício dessa função. Sendo natural, no curso desses processos, o surgimento de conflitos há que se criar mecanismos igualmente ágeis e eficientes para gerenciá-los. 
A adoção de regras administrativas desburocratizantes, voltadas à eficiência da Administração Pública e à solução rápida de conflitos, e a construção de um sistema democrático de relaçóes de trabalho no setor público, promovidas no bojo de um processo de releitura do Direito Administrativo e de revisão dos papel das entidades sindicais, em muito contribuirá para a adoção de um modelo de gestão compatível com o modelo de Estado e de sociedade democrática, amplamente preconizados na Constituiçâo Federal e requeridos pela cidadania.

É de esperar, portanto, que as liçōes emanadas dessas experiências concretas contribuam para que administradores, lideranças sindicais, partidos políticos e usuários dos sistemas púbicos de serviços construam um modelo administrativo democrático, sustentado na descentralização de poderes, na atuação propositiva de entidades sindicais e no controle social a ser exercido por entidades representativas dos usuários, capaz de selar uma aliança a favor dos mais legítimos interesses da cidadania.

\section{A Proposta Petista e seus Fundamentos para a Prefeitura Municipal de São Paulo}

Os estudos, apresentados a seguir, foram elaborados pela Secretaria Municipal da Administração de São Paulo, por deteminação direta da Prefeita Luiza Erundina de Souza. Destinaram-se a fundamentar a proposta de introdução do Sistema Permanente de Negociação Coletiva de Trabalho ${ }^{1}$ naquela administração municipal - o que, conforme demonstrado em nosso comentário anterior, acabou não acontecendo. Em que pese a não efetivação do projeto, em sua totalidade, a qualidade desta reflexão e o embasamento teórico que sustenta suas proposiçöes constituem uma das mais importantes contribuiçöes para o desenvolvimento das relações de trabalho no setor público, conforme se verá.

\section{Política de Pessoal na Administraçāo Pública ${ }^{2}$}

A formalização de uma proposta de política de pessoal na Administração Pública deve considerar a necessária democratização da administração do Estado e a urgente melhoria dos niveis de qualidade dos serviços prestados à população. Afirmar estas necessidades não é novidade. Novo é vinculá-las como objetivos-fim da administração de pessoal no serviço público.

1 Veja, a seguir, Exposição de Motivos e Projeto de Lei encaminhado à Câmara Municipal de São Paulo pela Prefeita.

2 Trabalho elaborado pela Secretaria Municipal da Administração da Prefeitura do Município de São Paulo - Gestáo Luiza Erundina de Souza (1989 - 1992). Técnicos da Assessoria de Relaçōes do Trabalho responsáveis pelo projeto: Carlos Francisco Cecconi - Assessor Técnico, Adriana Ancona de Faria Assessora Técnica, Sigueko Kimura - Administradora I, Sílvia Cristina Federighi - Administradora I, Solange Maria Santos Oliveira - Psicóloga I, Célio Almeida de Carvalho - Estagiário Sociologia, Douglas Gerson Braga - Assessor (convidado). 
Visando a alcançar estes objetivos, partimos de duas perspectivas para a formulação de nossa proposta: a primeira, que nos permitisse vislumbrar o trabalho e a atividade dos trabalhadores de forma mais global; e a segunda, que nos facultasse entender a administração das relações do trabalho como administração de conflitos.

Acreditamos que estas duas perspectivas nos trariam as condições necessárias para o desenvolvimento de uma proposta de relacionamento com os servidores, através de modelos novos e democráticos. Atendo-se a estes objetivos e perspectivas mais gerais, optamos pela expressão Relações do Trabalho. Com ela, pretendemos identificar as interaçōes que se dáo entre diferentes agentes no que diz respeito aos problemas do trabalho. É, portanto, mais complexa do que a expressão Recursos Humanos.

Estamos acostumados a tratar a administração de pessoal, principalmente na Administração Pública, a partir de procedimentos centralizadores e sob uma ótica que não consegue vislumbrar o trabalho e os trabalhadores no processo produtivo. Basta verificar os fundamentos do que se designa Recursos Humanos.

\section{A Perspectiva dos Recursos Humanos}

Denomina-se como Recursos Humanos "o conjunto de princípios, estratégias, processos, métodos e práticas de persuasão e treinamento empregado pelas empresas para o desenvolvimento de conhecimentos, motivações, interesses, habilidades e aptidões de seus funcionários, capacitando-os técnica e funcionalmente". (Sandroni, Dicionário de Economia).

$\mathrm{Na}$ denominação Recursos Humanos, encontra-se implícita uma teoria que vê o trabalho como um fator de produção entre outros, equiparando-o aos demais.

Na verdade, a produção é muito mais uma atividade social, uma atividade humana; é a transformação de matérias-primas pelo trabalho humano para a conservação da vida. Esta realidade seria evidente não fossem dois séculos de ideologia utilitarista.

Ao afirmar o trabalho humano como recursos humanos, a perspectiva dos administradores de pessoal parte de somente um dos atores envolvidos nas relações do trabalho: é a perspectiva do empregador. A motivação, capacitação e integração são aspectos importantes para a relação do trabalho, mas se é pretendida uma política global de gestão de pessoal, não se pode ter em vista somente a perspectiva de uma das partes envolvidas.

Mais do que isso, tal perspectiva fundamenta-se a partir de conceitos das teorias da organização, onde busca seus modelos de gestão, entre as quais tem maior destaque o enfoque sistêmico. Enesse sentido, gostaríamos de apresentar algumas consideraçóes críticas.

Ao se apresentar como teoria, busca, a partir de um esquema conceitual, descrever, explicar, interpretar, prever, prescrever e controlar o seu objeto de estudo. Portanto, ela procura fornecer respostas validadas ao fenômeno que estuda e, nesse sentido, tem muito a contribuir. $O$ problema encontra-se na medida em que partir de um esquema conceitual também é ideologia. E como ideologia é transmitida formal e informalmente e, mais do que fornecer respostas validadas, pretende tornar-se uma justificação de uma prescrição sobre a realidade que atua. Mais ainda, torna-se uma justificação de um modo particular de divisão do trabalho e da produção, da ordem social e econômica. 
É no estruturalismo-funcionalismo que a abordagem sistêmica busca os seus principais conceitos e fundamentos para se constituir em teoria e metodologia, dentre as quais o do acionismo social e o do imperativismo funcional.

O acionismo social entende as ações humanas e as relacões sociais reduzidas a padrões uniformes e dignos de confiança, pois explica a ação humana como um processo de escolha dos meios e fins possiveis para o seu desenvolvimento. Escolha que obedece a uma orientaçăo normativa e valorativa, a variáveis-padrảo. Em termos organizacionais, significa que a ação dos agentes está compreendida no desempenho de seus papéis, prescrita e sancionada por normas, a partir de certos valores enraizados.

$O$ imperativismo funcional afirma que todo sistema enfrenta quatro dimensões que não pode deixar de satisfazer. São os subsistemas que, aplicados à teoria organizacional, descrevem (ou prescrevem) os focos de funcionamento organizacional: subsistema de produção, subsistema de apoio, subsistema de manutenção e subsistema adaptativo.

Desta forma, a divisão do trabalho é justificada, pois é resultante de uma especificidade funcional de papéis. Podemos, mesmo, afirmar que tal abordagem, ao criar subsistemas em papéis hierárquicos, acaba favorecendo a burocracia; e ao criar subsistemas em papéis específicos, favorece a tecnocracia. O que também significa a justificação da necessidade do poder de controle e direçăo.

Tudo está reduzido a um sistema de papéis formalizados, em que a divisão do trabalho é um efeito do sistema e não um processo imposto pelo modo de produção. A partir desse arranjo informal do modelo comportamental em papel, os conflitos (e mesmo as práticas) dos agentes nas organizaçōes são reduzidos a conflitos de papel.

A abordagem sistêmica, assim como a maioria das teorias administrativas e organizacionais, é limitada, na medida em que não examina o lugar da força de trabalho na sociedade, o lugar que ocupa a força de trabalho no desenvolvimento do processo produtivo.

O processo de divisão do trabalho (não só) é que provoca a transformação da humanidade trabalhadora em uma força de trabalho, em um fator de produção, em um recurso entre outros. É a transformação dos trabalhadores em máquinas dóceis, obedientes e produtivas e que só conseguem vislumbrar uma luta individual para reconquistar sua condição de sujeito. O que vale dizer: a degradação do trabalhador passa a ser norma e se difunde por todas as ocupações.

$O$ assunto é polêmico, mas o entendemos extremamente importante para apontar algumas questões fundamentais para uma política global de gestão de pessoal, quais sejam:

- não ter a perspectiva de somente uma das partes que interagem no processo produtivo;

- não tratar o trabalhador apenas de forma individual;

- entender o produto do trabalho na Administração Pública como produto de serviços públicos essenciais que devem ser prestados à população, aos cidadăos. Não é tão-somente a produção de uma mercadoria. 
A Prefeitura da terceira maior cidade do mundo, que tem mais de 130.000 funcionários, deve tratar os problemas das Relações do Trabalho, da definição de uma Política de Gestão de Pessoal, de uma Política Salarial, considerando estas questões.

\section{A Tendência Atual da Administração de Pessoal}

Em nosso país, até o final da década de 60 , a administração de pessoal nas organizações era reduzida a unidades operacionais, e seus chefes de pessoal eram pessoas mais ou menos improvisadas, advindas de serviços operacionais. Conforme $o$ tamanho da organização, estas unidades assumiam algum destaque e os chefes de pessoal eram por vezes advogados, em razão da legislação trabalhista.

A partir da década de 70, com o surgimento de grandes e médias empresas que passaram a ter também a preocupação das relações humanas, a partir do exemplo e sucesso obtido internamente nas grandes multinacionais e, mais tarde, com o desenvolvimento do sindicalismo, tornou-se forçoso o estabelecimento de uma política de pessoal nas organizações.

Até porque se os funcionários passam a se organizar em sindicatos, a direção da organização não pode ignorar os aspectos coletivos do tratamento que lhes confere. Com efeito, não foi outro o problema enfrentado pelos administradores de pessoal, quando eclodiram as greves de metalúrgicos no $\mathrm{ABC}$, no final dos anos 70 , sendo este um dos motivos pelo qual as greves tinham longa duração.

Com estas novas preocupaçōes, passou-se então da improvisação anterior para um movimento de profissionalização do administrador de pessoal. Essa profissionalização (em razão inclusive de sua origẹm sistêmica e das relaçōes humanas) foi marcadamente multidisciplinar, a partir da icolaboração de diversos profissionais como advogados, psicólogos, pedagogos, sociólogos, analistas de O\&M, analistas de custos etc., que chegaram também a promover centros de formação que satisfizessem à demanda de administradores de pessoal, incluindo faculdades de administração de empresas.

Com essa expansão, a Administração de Pessoal passou a se encarregar de uma gama maior de atividades, tais como: planificação da mão-de-obra, contratação de pessoal, seleção, formação, classificação, avaliação de tarefas, qualificação, movimentos de pessoal, administração de salários, administração de benefícios, tramitação de queixas, atenção à segurança e medicina do trabalho, promoção da motivação, da satisfação e da produtividade, elaboração e revisão do regulamento da empresa etc.

Com o desenvolvimento do sindicalismo e a crescente importância dos acordos e convençōes coletivas do trabalho, somou-se às atividades mencionadas a administração destes acordos. Esta coexistência com a celebração de instrumentos coletivos do trabalho provocou inevitavelmente uma diminuição da autonomia dos administradores de pessoal, levando-os a pensar que suas atividades estariam reduzidas a uma função meramente executiva e mecânica.

No entanto, deve-se considerar que a celebração de um instrumento coletivo de trabalho nāo consegue regulamentar absolutamente tudo (e pensamos principalmente em grandes organizações), de tal modo que há sempre a margem para uma 
política de pessoal que abranja outros aspectos do desenvolvimento da força de trabalho e, até mesmo, a administração dos acordos coletivos.

Com todas estas atividades, é na grande empresa que a administração de pessoal encontrou real importância. Lá também surgiram, principalmente em razăo da introdução do aspecto coletivo, a proposição e o desenvolvimento da participaçăo dos trabalhadores na organização.

Talvez pelo fato de as circunstâncias socioeconômicas inerentes às relações do trabalho descartarem a introdução de formas de participação, embora bastante propaladas, as experiências concretas de participação tenham sido muito pouco desenvolvidas nas empresas.

Por outro lado, o termo participação pode ter significados bastante diversos. Não podemos entender por participação, por exemplo, contatos informais entre trabalhadores e seus gerentes, pois tais formas se particularizam pela eventualidade $\mathrm{e}$ seus resultados se caracterizam pela incerteza.

Para formular uma proposta de participação, deve-se entendê-la como uma forma de acesso normal e institucionalizado ao processo de tomada de decisões, sejam estas referentes à administração geral da organização, sejam referentes às relações do trabalho.

Para a proposta que ora apresentamos, entendemos a participação como a possibilidade que se reconhece aos trabalhadores de exercer influência efetiva sobre as decisões adotadas nas organizações. Portanto, a simples informação não é, na nossa opinião, uma forma de participação, mas sim uma forma útil de comunicação e um requisito indispensável para a negociação (este ponto desenvolveremos mais adiante).

A tendência atual da Administração de Pessoal é a de incorporar novas proposiçōes de participação dos trabalhadores e introduzir-se nos aspectos coletivos das Relações do Trabalho. Com isto, ela ganharia maior importância na administração das organizações e poderia imprimir um caráter mais dinâmico à sua gestão. Para tanto, terá que conseguir ganhar em imaginação no tratamento dos aspectos coletivos das relações do trabalho. E nisto reside sua grande contribuição para as transformações e consolidaçōes democráticas na sociedade brasileira.

E se este é um desafio para a Administração de Pessoal, hoje, mais ainda o é na Administração Pública, pois esta é voltada fundamentalmente para a prestação de serviços e, portanto, se desenvolve a partir do trabalho de milhares e milhares de funcionários públicos.

E temos que considerar que a Administração Pública hoje, para a ótica da administração de pessoal, também se caracteriza coma uma grande organização, sem tradição no tratamento dos aspectos coletivos das relações do trabalho. A liberdade de organização sindical dos servidores é recente: foi conquistada na Constituição Federal de 1988.

\section{Os Atores nas Relaçōes do Trabalho}

Já afirmamos que ao optarmos pela expressão 'relações do trabalho' pretendemos identificar as diversas interaçôes que se dão entre diferentes agentes, no que diz respeito aos problemas do trabalho. Nesse sentido, já é uma opção clara em entender 
o problema não apenas como administração de pessoal, caracterizada pela mão única da hierarquia, da autoridade, da competência e do controle, que só consegue vislumbrar a participação do trabalhador em algumas atividades consultivas.

Identificamos o problema pelo seu aspecto relacional, pois o campo do trabatho, do processo produtivo e, conseqüentemente, da organização do trabalho, caracteriza-se, fundamentalmente, pelas relações que se dáo entre atores distintos. $O$ que o caracteriza (o campo do trabalho) também como uma realidade social; e, portanto, algo mais global e complexo do que meramente organizacional.

Desde a década de 70 , as relações do trabalho no Brasil têm se direcionado para o comportamento autônomo de seus atores. Ou seja, as partes passaram a tomar para si maior responsabilidade na regulação de suas interações e na fixação das condições de trabalho. É nesta linha que se argumenta contrariamente à intervenção estatal e favoravelmente à liberdade e autonomia de organização sindical.

Ora, na medida em que as relações do trabalho passam a se evidenciar pela liberdade e autonomia dos atores envolvidos, apontando para mudanças democráticas, tais aspectos passam a influenciar no surgimento de novos modelos de gestão nas organizaçōes. Quer dizer: as livres interações de atores distintos nas relações do trabalho promovem mudanças para além das relações em si.

Por atores distintos não estamos designando apenas o empregador e os trabaIhadores. Não é o caso aqui de nos prendermos a uma análise pormenorizada, mas podemos indicar outros atores: a Justiça do Trabalho, o Ministério do Trabalho, o Congresso Nacional, por exemplo. Além destes, há outros mais importantes (principalmente em razão da tendência à autonomia): os sindicatos dos trabalhadores não são iguais entre si, mas se relacionam entre si e, por vezes, são quase que atores bastante diversos; e também os empregadores, mesmo em se tratando de uma única organizaçăo, assumem posições bastante divergentes. Ou seja, as interações intra-atores são igualmente importantes e, por vezes, podem também identificar atores diversos.

Na Administração Pública acreditamos que os atores nas relaçōes de trabalho têm ainda mais complexidade. Em nosso caso específico (PMSP), podemos identificar inicialmente os seguintes atores:

- o Executivo Municipal e suas formas de representação nessas interaçóes;

- os servidores municipais e suas organizações sindicais;

- os usuários dos serviços públicos;

- a Câmara Municipal, Poder Legislativo independente que legisla sobre o assunto.

Além da complexidade que cada ator representa, fatores externos às interações entre eles exercem influências nas relaçóes de trabalho: a forma como os atores se organizam, o poder que têm de mobilização junto a seus pares ou junto à opinião pública, frente a proposições que defendem, e a conjuntura político-econômica interferem muito em suas interaçóes, chegando mesmo, em dados momentos, a dar maior relevância a determinados atores (ou a coligação entre eles) em detrimento dos demais.

Nesse sentido, vale lembrar que está em curso na PMSP um movimento de desenvolvimento e fortalecimento das organizaçóes sindicais, que tende a crescer $e$ dar maior importância a essas entidades, nas interações das relações do trabalho. 


\section{O Conflito nas Relaçōes do Trabalho}

Como as interações nas Relações do Trabalho se dão entre atores com interesses distintos, divergentes e contrapostos, elas são, geralmente, interações conflituosas.

Podemos definir o conflito como "uma forma de interação entre indivíduos, grupos, organizaçóes e coletividades que implica em choques para o acesso e a distribuição de recursos escassos" (Bobbio, Dicionário de Política).

Reconhecer o conflito como uma particularidade das interações nas relações do trabalho significa não considerá-lo uma disfunção, uma patologia que deva ser reprimida e eliminada; e sim, considerá-lo como fator qualitativamente bom, pois é também através dele que surgem as mudanças e as melhorias do processo produtivo. Equivale a afirmar que o conflito, portanto, não é uma patologia, é vitalidade.

Nas relaçôes do trabalho, os conflitos, apesar de latentes, não são necessariamente manifestos e, se manifestos, não se desenvolverão necessariamente abertamente. Para que haja a manifestação aberta de um conflito é necessário alguma forma de organização, como, por exemplo, as greves e manifestações dos trabalhadores.

No campo das relaçōes do trabalho, podemos distinguir entre conflitos organizados e não organizados, individuais. Os primeiros não esgotam todas as manifestações conflituais do trabalho. A alta rotatividade, o absenteísmo, a indisciplina, são formas, apesar de ambivalentes (e por vezes tratadas como desmotivação), de conflito individual ou não-organizado. Pesquisas assim o demonstram: em locais onde líderes sindicais mais combativos foram demitidos ou se demitiram, registrou-se uma diminuição das greves, mas também um aumento do absenteísmo, da rotatividade e até de acidentes.

A importância em distinguirmos os conflitos em organizados e não-organizados reside no fato de que os primeiros traduzem a insatisfação em objetivos reivindicáveis e negociáveis, permitindo, portanto, sua composição. Os conflitos não-organizados, por sua vez, não desembocam necessariamente em reivindicações.

Para a Administração Pública, voltada quase exclusivamente para a prestação de serviços a partir do trabalho dos funcionários públicos, essa característica conflituosa das relações do trabalho assume maior importância, pois é claro que os conflitos interferem diretamente na qualidade do serviço prestado.

Se concordamos que a produção de antagonismo é constante, e que os conflitos não podem ser eliminados arbitrariamente, a não ser no curto prazo, pois eles persistem e retornam sempre, e considerando que a má qualidade do serviço público é um sintoma, dentre outros motivos, da não administração desses conflitos, torna-se necessário, portanto, criar um instrumento que dê conta de administrá-los e que resulte na conseqüente melhoria da qualidade dos senviços prestados.

\section{Negociação: a composição do conflito}

A composição do conflito é possível quando existem mecanismos para sua adaptação ou auto-regulagem estabelecidos em um Sistema de Relações do Trabalho. A existência desses mecanismos de adaptação implica o reconhecimento do conflito como intrínseco a estas relaçōes. 
Trata-se de canalizar os conflitos para formas previsíveis, submetê-los a regras precisas, explícitas e transparentes, definidas pelas partes. Significa estabelecer um instrumento peculiar pelo qual as partes administram suas relações de trabalho: a negociação coletiva. Este instrumento constitui-se um processo de estabelecimento de regras que normatizam as relações de trabalho, o comportamento das partes ao compor seus conflitos, a participação de terceiros e o uso de arbitragem.

Nesse sentido, a negociação coletiva é um processo de tomada de decisões. Seu propósito primordial é estabelecer um conjunto de normas sobre as questóes de fundo e de procedimento das relações de trabalho. Enquanto tal, ela é um procedimento qualitativamente superior aos demais, pois enriquece o processo de tomada de decisões. Trata-se de um meio de fixar, em comum, condições de trabalho e salariais; de regular as relaçōes trabalhador/empregador; de dirigir organizações complexas; de planejar o processo de trabalho e de prestação de serviços. Se viabilizada em sua plenitude e complexidade, pode vir a ser um meio de gerir em comum a própria atividade produtiva. De instrumento, passa a ser uma concepção de gestão.

A negociação coletiva, como um processo integrado, articulado e criativo, é o principal meio para resolver conflitos de interesse em situações caracterizadas pela escassez de recursos. Ela não anula o aspecto conflitivo das relaçōes, mas oferece a cada parte a possibilidade de intercambiar informações, de forma a compenetrar-se dos problemas e objetivos da contraparte, tanto no que diferem, quanto no que coincidem.

\section{Características da Negociação Coletiva}

Uma de suas principais características é apresentar grande flexibilidade no processo de tomada de decisōes, dando-lhe possibilidades para adaptar-se a um sistema econômico e político, bem como para ajustar-se, dentro de um contexto determinado, a um ramo de atividade específico, a um conjunto de empresas, ou, até mesmo, a um só local de trabalho.

A negociação coletiva institucionaliza o conflito de poder existente entre as partes; constitui um veículo normativo, através do qual as partes administram formalmente seus conflitos; estabelece um procedimento que regulamenta desde o processo mesmo de negociação, até o comportamento dos negociadores e submete os negociadores a pressōes externas. Por ter essas características, evita o favoritismo, o nepotismo, a arbitrariedade e o corporativismo nas relaçōes do trabalho.

Para que a negociação coletiva seja eficaz, as partes devem concordar em alguns aspectos (que também a caracterizam), sem os quais inviabilizariam o próprio processo de negociação:

- devem reconhecer-se mutuamente como representantes autorizados;

- estarem dispostas a reunir-se em intervalos razoavelmente freqüentes;

- decidirem o grau de autoridade que delegam a seus respectivos negociadores. 
O reconhecimento mútuo significa que as partes se obrigam ao cumprimento de entabular negociaçóes, em um processo que se apóia na confiança recíproca entre os participantes, sendo essa confiança somente conseguida quando existe boa fé. $O$ que obriga as partes a:

- desenvolverem esforços para chegar a um acordo;

- não aparentarem negociar sem terem a intenção real de negociação;

- não definir unilateralmente as condições de trabalho e emprego;

- e, o empregador, a não tratar diretamente com os funcionários, passando por cima dos negociadores reconhecidos pelos trabalhadores.

Como as decisões sobre as relações do trabalho são tomadas em processo de negociação entre partes autônomas, determinadas questões sairão do campo das decisōes unilaterais para ingressarem no campo das bilaterais. Esse campo de ação paritário na negociação coletiva tende a se ampliar cada vez mais. Nesse sentido, ela representa também a implantação de práticas democráticas na organização e no processo de trabalho.

Se decisões serão tomadas em processos de negociação, cabe a pergunta: que questōes são negociáveis, ou ainda, que questões ingressam no campo de ação paritário? É indiscutível que são negociáveis questôes fundamentais como salários, jornada de trabalho e condições gerais de emprego. Mas, hoje, empregadores e sindicatos já negociam e regulam, por exemplo, regimentos internos, proteção ao desemprego e, até mesmo, a ampliação do conteúdo do trabalho, com o objetivo de se obter uma atividade mais qualificada.

Não se deve ter a errônea noção de que a negociação coletiva tenha somente implicaçōes econômicas. É importante que se tenha claro que o processo de negociação coletiva é um sistema de mão dupla, o que vale dizer que ambas as partes estão em condiçōes de estar apresentando propostas que venham a ser negociadas ou utilizadas como contrapartida a uma reivindicação de uma das partes. Permite, por exemplo, à Administração buscar mecanismos que possibilitem um melhor desempenho do serviço público, elevando a qualidade do atendimento ao usuário.

\section{Sistema de Negociaçāo Permanente}

A complexidade e dinâmica do conflito induzem à criação de um sistema capaz de dar conta de questões relativas especificamente a cada local de trabalho e também de questōes mais gerais, envolvendo toda a categoria de trabalhadores. Nesse sentido, diversos países já adotam processos permanentes de negociação coletiva (aqui já temos a experiência do (AMSPE).

Portanto, não negociam somente salários e condições de trabalho, pois se ocupam também de matérias relacionadas com problemas mais simples e reduzidos ou mais amplos e complexos do que as questões econômico-salariais. O que significa que não se trata apenas do estabelecimento de um processo corporativista de negociação, desenvolvido exclusivamente a partir de reivindicações econômicas apresentadas pelas organizações sindicais dos trabalhadores. Implica, na verdade, uma outra concepção de administração do processo de trabalho. 
O estabelecimento de um órgão permanente de negociação coletiva envolve o necessário reconhecimento da outra parte (trabalhador) como preponderante no desenvolvimento do processo produtivo. Preponderante também na medida em que se reconhece sua autonomia nos processos de negociação, decorrência do direito à liberdade e autonomia de organização sindical. Trata-se, portanto, de mudança na forma de estabelecer o desenvolvimento do processo produtivo: passa a ser definido através da composição das partes e não pela imposição de uma parte à outra.

Este procedimento implica, necessariamente, uma maior participação do trabalhador no processo produtivo, o que lhe possibilita maior compreensão das relações de trabalho em que está envolvido. Passa-se, portanto, a percorrer um caminho inverso ao daquele imposto pela divisão do trabalho e que provocou o alto grau de alienação. Não é difícil perceber a importância disto no setor público e na prestação de serviços.

Estes organismos permanentes são compostos por representantes indicados pelas partes e geralmente têm até estatutos próprios, constituídos de comum acordo, em que são definidos os principais objetivos e outras questöes de procedimentos. Chegam mesmo à contratação conjunta de pessoal para secretariar o processo, visando à continuidade independente dos trabalhos da mesa de negociação.

As vantagens de um sistema permanente estão em concretizar, de forma mais definida e clara, as características da negociação coletiva; em dar às partes a possibilidade de estudarem juntas as perspectivas e problemas da atividade quedesenvolvem (no nosso caso, o serviço público); em factibilizar a aplicação e fiscalização conjunta dos convênios firmados; e em erigir um sistema comum de relações do trabalho, no qual as partes possam abordar juntas os problemas que são objeto de negociação, como também questões econômicas e sociais de maior envergadura. É a democratização das interações nas relaçóes do trabalho.

Em nosso caso específico é a possibilidade de as partes, juntas, buscarem a consecução de seu objetivo maior: a melhoria da qualidade dos serviços públicos prestados à população.

E desejamos afirmar que a boa ou má qualidade dos serviços públicos é, inevitavel e principalmente, expressão direta da forma como a Administração Pública vem tratando os conflitos de relações de trabalho. Se assim entendemos, devemos também concordar que é interesse primordial da Administração Pública buscar mecanismos que the propiciem administrar esses conflitos de forma democrática, transparente, eficiente, eficaz, criativa e dinâmica. Entendemos que esta forma é a Negociação Coletiva do Trabalho, a partir de um sistema permanente, articulado, integrado e que goze de absoluta credibilidade junto às partes.

Temos a certeza de que melhorar as condições de trabalho no serviço público significa elevar o grau de resolutividade da prestação dos serviços à população. Este é o nosso objetivo. 


\section{Fundamentos Legais da Negociação Coletiva no Setor Público}

Antes de qualquer explanaçăo a respeito de nossa legislação sobre o tema, não podemos deixar de lembrar a Convenção 151 da Organização Internacional do Trabalho (OIT), datada de 7/06/78 que trata da "proteção do direito de sindicalização e os procedimentos para determinar as condições de emprego na administração pública", da qual queremos destacar dois artigos:

Art. 70 - Deverão adotar-se medidas adequadas às condições nacionais para estimular e fomentar o pleno desenvolvimento e utilizaçăo de procedimentos de negociação entre as autoridades públicas competentes e as organizações de funcionários públicos a respeito das condiçōes de emprego, ou de quaisquer outros métodos que permitam aos representantes dos funcionários públicos participar na determinação destas condições.

Art. 8 - A solução dos conflitos que ocorram pelo motivo da determinação das condiçôes de emprego, se deverá tratar de lograr, de maneira apropriada às condições nacionais, por meio de negociação entre as partes ou mediante procedimentos independentes e imparciais, tais como a mediaçāo, a conciliação e a arbitragem, estabelecidos de modo que inspirem a confiança dos interessados.

A Convenção 151 da OIT, estabelecida em sua Conferência Geral, além de recomendar o direito e a liberdade de organização sindical aos funcionários públicos, também consagra a negociação coletiva como o meio adequado para a administração de conflitos nas relações de trabalho e para o estabelecimento de normas e condições de trabalho no serviço público.

Cientes do incentivo do organismo internacional, analisemos as possibilidades presentes em nossa legislação.

Alguns especialistas em Direito Administrativo apresentam como obstáculo à celebração do processo contratual a hipótese de inaplicabilidade do instituto da Negociação Coletiva de Trabalho para o setor público. Verifiquemos tal hipótese.

A Constituição Federal de 1988 (CF) assegurou aos servidores civis o direito à livre associação sindical (artigo 37, Vl) e conferiu, aos sindicatos, representação legal, coletiva e individual, dos trabalhadores de sua categoria profissional. É bastante claro o inciso III do artigo 8 o da CF:

"III - Ao sindicato cabe a defesa dos direitos e interesses coletivos ou individuais da categoria, inclusive em questōes judiciais ou administrativas."

0 inciso $V I$ do mesmo artigo da CF dispóe especificamente a respeito do assunto:

"V1 - É obrigatória a participação dos sindicatos nas negociações coletivas de trabalho" (grifo nosso).

E vale lembrar que a Lei Orgânica do Município de São Paulo (artigo 93), ao legislar sobre a livre organização sindical dos servidores municipais, remeteu ao mesmo artigo $8^{\circ}$ da CF:

"Art. 93 - É garantido ao servidor público municipal o direito à livre associação sindical, nos termos do artigo 80 da Constituição da República." 
Por outro lado, a Constituição Federal, no artigo 39, parágrafo segundo, assegura aos servidores públicos parte dos direitos sociais relacionados em seu artigo $7^{\mathrm{9}}$. Entre estes, tais incisos confirmam a intenção do legislador constituinte, quanto à prerrogativa de celebração de acordo coletivo de trabalho, no setor público, a saber:

"VI - Irredutibilidade do salário, salvo o disposto em convenção ou acordo coletivo;"

"XIII - Duração normal do trabalho não superior a oito horas diárias e 44 semanais, facultada a compensação de horário e a redução de jornada, mediante acordo ou convenção coletiva do trabalho."

Mais que isso, e dirimindo eventual controvérsia, a Lei Orgânica do Município de São Paulo (LOM), promulgada em 6/4/90, por intermédio do artigo 96, acolheu expressamente o inciso XXVI do artigo $7^{\circ}$ da $\mathrm{CF}$, assegurando aos servidores municipais:

"XXVI - Reconhecimento das convenções e acordos coletivo do trabalho."

A boa regra da hermenêutica ensina que não cabe ao intérprete interpretar matéria efetivamente legislada. Trata-se, pois, de dar cumprimento ao que a lei estabeleceu. Nesse sentido, está preservado o principio da legalidade, uma vez que a prerrogativa de celebrar instrumentos contratuais coletivos no setor público municipal está prevista legalmente.

É importante ressaltar que, entre o processo constituinte federal e as assembléias constituintes municipais, firmou-se claramente a tendência de reconhecimento explícito da viabilidade de negociação e contratação coletiva de trabalho no setor público. Também é fundamental registrar que esta interpretação não se resumiu aos juristas, mas foi objeto de deliberação dos legítimos representantes da vontade popular, quais sejam: os legisladores constituintes municipais. Por estes, a matéria foi transportada do campo interpretativo para o campo expressamente legislativo.

É evidente, portanto, que o exercício das liberdades sindicais pelos servidores públicos, nos termos da CF e da LOM, pressupõe o direito de representação e, conseqüentemente, de firmar convênios coletivos, em nome de seus representados.

\section{A Coordenação de Relaçōes do Trabalho}

A complexidade das relações do trabalho na PMSP, considerando-se as características dos atores que interagem em seu processo, o grande número de funcionários e de locais de trabalho existentes e o desenvolvimento e fortalecimento das organizações sindicais dos servidores justifica a necessidade da organização de uma equipe de profissionais com as seguintes atribuições:

- formular e apresentar para aprovação pela Administração Municipal o programa e a estratégia de negociação coletiva, incluindo seus objetivos;

- reunir todas as informações necessárias ao processo de negociação coletiva, visando a assessorar, orientar e fornecer subsídios para a Administração;

- emitir relatórios mensais de dados estatísticos da folha de pagamento da PMSP, procedendo à análise técnica dos mesmos, bem como à análise comparativa com o mercado da cidade de São Paulo; 
- receber as reivindicações das organizações sindicais dos servidores, procedendo a avaliaçōes das mesmas e encaminhando-as à Administração Municipal;

- recomendar à Administração Municipal as decisōes críticas que deverão ser tomadas durante o processo de negociação, mantendo-a permanentemente informada sobre o andamento do mesmo;

- elaborar e apresentar para aprovação pela Administração Municipal as propostas e contrapropostas que serão apresentadas aos representantes sindicais, com vistas ao estabelecimento de Acordo Coletivo;

- representar a Administração Municipal na mesa de negociação coletiva;

- atender às solicitações das Secretarias Municipais, no tocante a problemas de relações do trabalho;

- informar periodicamente a terceiros sobre o andamento da negociação;

- criar e manter atualizado o cadastro das entidades sindicais dos servidores;

- criar e manter atualizado o cadastro das reivindicações e contrapropostas apresentadas em negociação coletiva;

- manter atualizado arquivo dos acordos estabelecidos com as entidades sindicais e suas conseqüenciais legais e administrativas;

- desenvolver estudos da caracterização dos conflitos nas relações de trabalho no serviço público municipal.

Propomos, para tanto, a criação da Coordenação de Relações do Trabalho (CRT), vinculada ao gabinete da Secretaria Municipal da Administração.

A CRT deverá ter uma pequena estrutura para comportar um número pequeno de auxiliares (duas secretárias e três oficiais gerais de administração) que garantam o desempenho das atividades rotineiras, de uma equipe técnica composta de três administradores, um estatístico, um psicólogo e um sociólogo, e de uma equipe de quatro assessores, de livre provimento em comissão. A equipe será coordenada por um coordenador de relações do trabalho, também de livre provimento em comissão.

Tal estrutura deverá integrar o processo de descentralização em curso na PMSP, até porque, com a implementação de um sistema permanente, a Mesa de Negociação Coletiva também deverá ser descentralizada, o que implica a criação de, pelo menos, um cargo de Assessor de Relacōes do Trabalho nas Secretarias e nas futuras Subprefeituras. A formalização dessa estrutura será objeto de minuta de Projeto de Lei a ser enviado à Câmara Municipal.

\section{Roteiro para Implantação do Sistema Permanente de Negociaçāo Coletiva de Trabalho na PMSP}

A implantação de tal sistema já está prevista pela Secretaria Municipal da Administração. Protocolo de Intenções nesse sentido já foi firmado com o Sindicato dos Servidores Municipais em 22/08/90. Outras entidades já estão previstas para firmarem o mesmo protocolo, como o SIMPEEM, o SINDSAÚDE, o Sindicato dos Médicos, o Sindicato dos Enfermeiros e outros. Para a continuidade desse processo, propomos o seguinte roteiro: 
Fase I - Discussão da Proposta

- escopo: princípios e linhas gerais, fundamentos teóricos, fundamentos jurídicos e administrativos e justificativas;

- subsídios: experiências verificadas no setor público e debates/conferências/cursos/estudos (níveis nacional e internacional).

Fase II - Formulação do Projeto

- apreciação, discussão e aprovação do projeto pelas partes (Executivo Municipal e Entidades Sindicais)

- apresentação e discussão com a Câmara Municipal.

Fase III - Implantação do Sistema

- definiçăo de etapas e montagem das equipes

- treinamentos

- articulação e definição de prioridades

- designação da Mesa de Negociação

- mobilização da opinião pública e sociedade civil.

Fase IV - Funcionamento do Sistema

- negociação direta e permanente;

- avaliação quanto à necessidade de arbitragem;

- celebração de instrumento coletivo do trabalho.

\section{Referências Bibliográficas}

FARIAS, J. H. de. O Autoritarismo nas Organizaçōes.Curitiba: Criar Ediçōes, 1985.

LOBOS, J. Sindicalismo e Negociação. 3.ed. Rio de Janeiro: José Olympio, 1988.

MOTTA, F. C. P. Teoria Geral da Administração.14.ed. São Paulo: Pioneira, 1987.

ORGANIZAÇÃO INTERNACIONAL DO TRABALHO (OIT). La negociación colectiva en países industrializados con economía de mercado, 1973.

ORGANIZAÇÃO INTERNACIONAL DO TRABALHO (OIT). Conciliación y arbitraje en los conflictos de trabajo, 1981.

\section{Projeto de Lei para a Administração Municipal}

O Projeto de Lei Ordinária, precedido da respectiva Exposição de Motivos, reproduzido a seguir e encaminhado à Câmara Municipal de São Paulo pela Prefeita Luiza Erundina de Souza, não chegou a ser aprovado. Considerando os fundamentos teóricos nos quais se baseou, publicados sob o título "Política de Pessoal na Administração Pública", esse conjunto de estudos e propostas concretas é um avanço para a efetivação de convênios ou de contratos apoiados em legislação de suporte, combjnação ideal de fórmulas para regular as relações entre administração, seus servidores e a população usuária dos senviços públicos. 
É importante destacar, ainda, a qualidade técnica do projeto e da elucidativa Exposição de Motivos que o acompanha, conduzidos sob a responsabilidade do eminente professor Dalmo de Abreu Dallari, titular da cadeira de Teoria do Estado da Faculdade de Direito da Universidade de São Paulo e, à época, à frente da Secretaria dos Negócios Jurídicos da Prefeitura de São Paulo. A publicação se justifica, portanto, pela contribuição que essas reflexōes oferecem aos estudiosos e demais interessados no assunto.

\section{Exposiçăo de Motivos}

Objetiva o presente projeto de lei instituir, no âmbito das relações entre o Município de São Paulo e seus servidores, o processo de Negociação Coletiva de Trabalho, em adequação aos preceitos atualmente vigentes, sobre a matéria, na Constituição Federal e na própria Lei Orgânica do Município.

Trata-se, na verdade, de ousada inovação, trazida pela Carta Magna de 1988, a incidir sobre tais relaçóes, cuja natureza jurídica é de há muito pacificamente reconhecida pela doutrina como sendo estatutária - em contraposição às relaçōes de trabalho de natureza contratual.

Com efeito, sempre se entendeu que a relação jurídica entre o trabalhador da ordem privada e seu empregador fosse de natureza contratual, implicando tal conceituação um trato dinâmico e sucessivo, privilegiando-se, resguardadas algumas garantias legais, o livre exercício da vontade das partes, numa permanente convivência de transigências e reivindicações, obtemperadas por condicionamentos históricos e fatores sociais, políticos, econômicos etc.

Veja-se o artigo 444 da Consolidação das Leis do Trabalho: "As relaçōes contratuais de trabalho podem ser objeto de livre estipulação das partes interessadas em tudo quanto não contravenha às disposições de proteção ao trabalho, aos contratos coletivos que. Ihe sejam aplicáveis e às decisões das autoridades competentes."

Diversa é, por outro lado, a natureza do vínculo que une o Poder Público e seus funcionários, a respeito do que preleciona, com habitual clareza, o renomado autor Joaquim de Castro Aguiar, em seu 'O Servidor Municipal', (p. 20):

É tese predominante na nossa doutrina e jurisprudência que o Poder Público não contrata comseus funcionários, tampouco com eles ajusta condições de serviço ou discute remuneração. Ao contrário, determina unilateralmente, todas as condições de trabalho, os direitos e deveres decorrentes do exercício das funçōes públicas.

Nāo poucas são as decisões dos nossos Tribunais em abono da tese de que a vinculação do Poder Público com seus funcionários é de natureza estatutária, não contratual. (os grifos correspondem a destaques no original).

A Negociação Coletiva de Trabalho, pressupondo contratos de trabalho e caracterizando-os como instrumento de aprimoramento permanente desses mesmos contratos é, pois, instituto originário do Direito do Trabalho (assim entendido como o ordenamento disciplinador das relações de empregados e empregadores da ordem privada) e estranho, até o advento da atual Constituição, à seara do 
Direito Administrativo, onde o livre exercício da vontade dos sujeitos das relaçốes jurídicas figura quase sempre como exceção - até porque jungidas ao primado da prevalência do interesse público.

O passo histórico, a providência verdadeiramente inovadora, apontados pela Constituição e pela própria Lei Orgânica do Município de São Paulo, estão exatamente em integrar ao Direito Administrativo, no âmbito das relações estatutárias, instituto do Direito do Trabalho, próprio das relaçōes celetistas.

Depois de ponderados estudos, órgãos técnicos do Executivo, sem embargo do reconhecimento das especiais dificuldades inerentes às inovações de tal magnitude, concluíram pela possibilidade da integração aludida, à luz de detida análise jurídica, tanto do texto constitucional, quanto da Lei Orgânica do Município.

Nesse passo, é de ser ressaltado que, diversamente das anteriores, a Constituição Federal de 1988 garantiu aos servidores públicos o direito de livre associaçăo sindical (artigo 37, VI). Direito este igualmente previsto na Lei Orgânica do Município (artigo 93) e, aqui, com expressa referência, ainda, ao artigo $8^{\circ}$ da Constituição Federal.

Ora, prever que a associação sindical relativa aos servidores do Município de São Paulo tenha a atuaçăo prevista no artigo $8^{\circ}$ da Constituição Federal é, forçosamente, prever que tal associação participe obrigatoriamente nas negociações coletivas de trabalho (conforme o inciso VI deste mesmo artigo), e que só podem, à evidência, ser com o Município de São Paulo.

De modo ainda mais evidente a Lei Orgânica do Município, inciso I do artigo 92 prevê "piso salarial definido em comum acordo entre a administração e a representação sindical dos servidores municipais". Não há, assim, como ignorar que a negociação coletiva de trabalho esteja claramente prevista no ordenamento jurídicoadministrativo municipal, até porque somente a ela poderia estar se referindo o Legislador, quando neste artigo usa a expressão comum acordo.

Inexistindo dúvida quanto à previsão da Negociação Coletiva de Trabalho, no ordenamento jurídico-administrativo municipal, os mencionados estudos apontam, entretanto, dificuldades quanto à implantação desse processo, na medida em que possa colidir com princípios indeclináveis que informam a atuação do Poder Público, tais como: o da legalidade, o da independência dos poderes, o da autonomia municipal e o da vedação da delegaçăo de competência, entre outros.

A presente propositura foi, portanto, elaborada com a especial preocupaçăo de evitarem-se exatamente as aludidas colisōes com tais, e outros, princípios - o que, de qualquer modo, a inviabilizaria, até por vício de inconstitucionalidade.

Assim é que previram-se, a par do processo negocial propriamente dito, vários outros condicionamentos, tais como a previsibilidade orçamentária (artigo 40, parágrafo único), a subordinação do que for acordado à apreciação e aprovação da Egrégia Câmara (artigo 80), a prevalência da qualidade dos senviços prestados à população (artigo 90), a indisponibilidade do interesse público (artigo 10, l) e a publicidade dos atos e procedimentos do processo de negociação coletiva (artigo 10, V). 
Com tais ponderações, submetemos a presente propositura à elevada consideração dessa Egrégia Câmara que, reconhecendo seu elevado alcance social, nela aporá seu imprescindivel aval.

\section{Projeto de Lei 01-0616/91-8}

Dispõe sobre a Negociação Coletiva de Trabalho no âmbito do Funcionalismo Municipal, e dá outras providências.

A Câmara Municipal de São Paulo decreta:

Art. 10. Fica institucionalizada, no âmbito da Administração Municipal, a Negociação Coletiva de Trabalho que, garantidos os preceitos mínimos de proteção ao trabalho, terá, como partes, a Prefeitura do Município de São Paulo e as entidades sindicais de seus funcionários, e como principal objeto:

I - a negociação de normas relativas a salários e demais condições de trabalho;

II - a celebração de acordos coletivos de trabalho e contratos coletivos de trabalhos, nos termos desta lei.

Art. $2^{2}$. Os servidores investidos em mandatos de dirigentes de entidades sindicais poderão ser afastados de seus cargos para cumprimento de seus mandatos.

Parágrafo Único. $O$ afastamento de que trata o caput deste artigo será pelo prazo do mandato em que o servidor foi investido e nas condiçōes estabelecidas em Acordo Coletivo de Trabalho entre o Executivo Municipal e as Entidades Sindicais do Funcionalismo Municipal.

Art. 3o. Negociação Coletiva de Trabalho é o procedimento pelo qual o Executivo Municipal e o Funcionalismo Municipal, estes representados por Entidades Sindicais, cumulativa ou separadamente, objetivam discutir, ajustar, regular e contratar direitos, obrigaçōes, salários e demais fatores e condiçōes atinentes à relação de trabalho na Prefeitura do Município de São Paulo, respeitados e garantidos os preceitos da Constituição Federal, da Lei Orgânica do Município de São Paulo e do Estatuto dos Funcionários Públicos do Município de São Paulo.

$\S 1^{9}$. Fica assegurado às partes, através do procedimento de Negociação Coletiva de Trabalho de que trata o caput deste artigo, o direito de ajustarem e celebrarem em Acordo ou Contrato Coletivo de Trabalho cláusulas que proponham alteração do Estatuto dos Servidores Municipais.

$\S 2$. . As alterações previstas no parágrafo anterior somente terão validade após apreciação e aprovação pela Câmara Municipal, através de projeto de lei a ser enviado pelo Executivo Municipal.

Art. 4\%. Por ocasiāo do processo de Negociação Coletiva de Trabalho, as partes poderão celebrar instrumentos coletivos de contratação de direitos e obrigações, especialmente os seguintes:

I - Acordo Coletivo de Trabalho;

II - Contrato Coletivo de Trabalho. 
Parágrafo Único. A celebração dos instrumentos coletivos de que trata o caput deste artigo só poderá ser feita se houver prévia ditação orçamentária suficiente para atender às projeçōes de despesas de pessoal $\mathbf{e}$ aos acréscimos delas decorrentes.

Art. 5o. Acordo Coletivo de Trabalho é instrumento de caráter normativo, celebrado entre o Executivo Municipal e, pelo menos, uma Entidade Sindical, para estipular normas sobre salários e demais condições de trabalho, aplicáveis no âmbito da respectiva representaçăo das Entidades Sindicais dele participantes.

Art. $6^{\circ}$. Contrato Coletivo de Trabalho é instrumento de caráter normativo celebrado entre as Entidades do Funcionalismo Municipal e o Executivo Municipal, para estipular normas sobre salários e demais condiçōes de trabalho, aplicáveis no âmbito da Administração Direta, das Autarquias e das Fundações.

Art. 7․ Os Acordos e Contratos celebrados entre o Executivo Municipal e as Entidades Sindicais do Funcionalismo Municipal obrigam as partes ao cumprimento do objeto ajustado, observado o disposto no artigo $8^{\circ}$ desta lei.

Art. 8‥ Os instrumentos celebrados em Negociação Coletiva de Trabalho que, na conformidade da Constituição Federal, da Lei Orgânica do Município e do Estatuto dos Funcionários Públicos do Município de São Paulo, só possam ser estabelecidos por lei, terão sua validade condicionada à apreciação e aprovação pela Câmara Municipal.

Parágrafo Único. O Executivo remeterá Projeto de Lei à Câmara Municipal, na conformidade do instrumento coletivo que for celebrado com as Entidades Sindicais do Funcionalismo Municipal e no prazo nele estipulado pelas partes.

Art. 9o. A Negociação Coletiva de Trabalho na Prefeitura do Município de São Paulo deve visar, como objetivo principal e permanente, ao aprimoramento das relações de trabalho entre o Executivo e os Servidores Municipais e à melhoria da qualidade dos serviços prestados à população.

Art. 10․ A Negociação Coletiva de Trabalho, como procedimento de averiguação e de composição de conflitos decorrentes das relaçóes de trabalho e de apreciação de reivindicações dos servidores, deverá observar os seguintes princípios básicos:

I - da indisponibilidade do interesse público;

Il - da liberdade de organização e do exercício da atividade sindical, inclusive do direito de greve;

III - da legitimidade da representação e do respeito à vontade soberana da maioria dos representados;

IV - da adoção de procedimento democrático de deliberação;

$V$ - da publicidade dos atos e dos procedimentos de natureza coletiva;

$\mathrm{VI}$ - do direito à resposta por escrito, em prazo compatível, sempre que requerido pela outra parte;

$\mathrm{VII}$ - do direito e acesso a informaçōes relativas a emprego, jornada e salário, dentre outras que sejam úteis ao processo de negociação coletiva, desde que solicitadas por uma das partes;

VIII - da autonomia do processo de negociação coletiva; 
IX - do caráter permanente do sistema de negociação, sendo facultado às partes convocar o processo negocial, a qualquer tempo;

$X$ - da eficácia e do poder normativo dos instrumentos celebrados, observado o disposto nos artigos $7^{\circ}$ e $8^{\circ}$ desta lei.

Art. 17\%. Por ocasião do processo de negociação coletiva, as partes poderão, de comum acordo, constituir um Conselho para apreciação e mediação da matéria negociada.

Parágrafo Único. Os membros do Conselho serăo representantes da Sociedade Civil e alheios a qualquer uma das partes integrantes do processo de negociação, sendo definidos de comum acordo entre o Executivo Municipal e as Entidades Sindicais do Funcionalismo Municipal.

Art. $12^{\circ}$. Cabe às partes contratantes a fiscalização e cumprimento dos instrumentos contratuais coletivos.

Art. 139. Os instrumentos contratuais coletivos deveräo conter:

I - designação das entidades contratantes;

II - periodização e prazos;

III - abrangência;

IV - direitos e obrigações ajustados;

$V$ - procedimentos para solução de divergências interpretativas sobre aplicação dos dispositivos contratuais;

$\mathrm{VI}$ - procedimentos de fiscalização e acompanhamentos da execução dos instrumentos celebrados.

Art. 149. Os instrumentos contratuais seráo elaborados de forma escrita, em tantas vias quantas forem as entidades contratantes e serão registrados junto à Presidência da Câmara Municipal, no prazo de 5 (cinco) dias contados de sua celebração.

Art. $15^{\circ}$. Os dispositivos contratuais somente poderão ser revogados ou alterados por força de nova contratação coletiva entre o Executivo Municipal e as Entidades Sindicais do Funcionalismo Municipal, observados, quanto à validade e vigência, os critérios estabelecidos por esta lei.

Art. 169. As despesas com a execução desta lei correrão por conta das dotações orçamentárias próprias.

Art. 179. Esta lei entrará em vigor na data de sua publicação, revogadas as disposições em contrário. Às Comissões competentes.

\subsection{ASSUNTOS RELACIONADOS À ÁREA DA SAÚdE}

\section{Modelo Contratualista do IAMSPE (segundo seus administradores)}

$\mathrm{Na}$ análise da experiência de Negociação Coletiva de Trabalho, produzida pelo Hospital do Servidor Público do Estado de São Paulo e transcrita a seguir, estão reunidos diversos elementos que permitem mensurar resultados e interpretar significados. $́$, 
portanto, excelente material de pesquisa para a comunidade interna da instituição e para a de usuários dos serviços, bem como para estudiosos do assunto e interessados em geral. Pela condição privilegiada dos autores, José Carlos Ramos de Oliveira e David Braga Júnior - responsáveis, à época, com dirigentes sindicais, pela implantação do modelo -, torna-se possivel conhecer os caminhos pelos quais trilham os processos de mudanças nas instituições. O IAMSPE volta a ser assunto na seção "Aos Sindicatos Combativos", e transcrevem-se peças do modelo no Roteiro em Seis Passos para Implantação de Sistemas de Gestão.

\section{Introdução}

A análise da implementação do Sistema Permanente de Negociação Coletiva de Trabalho no âmbito do Instituto de Assistência Médica ao Servidor Público do Estado, sua descrição e seus resultados, requer, primeiramente, reflexões que permitam uma contextualização clara da Instituição e dos determinantes políticos que envolveram essa iniciativa.

Em seguida a essas reflexões, discutiremos o modo como a proposta foi sendo assimilada pelos representantes dos servidores da instituição e como ela pôde tomar sua forma final, definindo-se seus limites de abrangência, sua operacionalidade e os aspectos legais que embasaram a iniciativa. Alguns exemplos de protocolos obtidos através da negociação serão enumerados.

Os resultados obtidos serão mostrados por meio dos reflexos ocorridos no âmbito institucional. O comparativo dos resultados quantitativos, realizado através de alguns indicadores de produção hospitalar, envolve um período de quatro anos, que vai desde o ano imediatamente anterior à nossa indicação para a direção daquela autarquia estadual (1987), até o final de 1990, já que no primeiro semestre de 1991 deixamos a direção daquele órgão.

Por fim, à guisa de conclusão, comentaremos alguns pontos que o Sistema Permanente de Negociação Coletiva de Trabalho permite alcançar no que se refere ao trato com os recursos humanos e as relaçōes de trabalho no setor público.

\section{Características Administrativas e Institucionais do IAMSPE e do HSPE}

O Instituto de Assistência Médica ao Servidor Público do Estado de São Paulo (IAMSPE) é uma autarquia do Governo do Estado de São Paulo, ligada funcionalmente à Secretaria de Estado dos Negócios da Saúde, mas administrativa e politicamente ao gabinete do Governador do Estado.

Sua organização administrativa segue um modelo matricial encabeçado por uma Superintendência, sob a qual estão afetos três departamentos, a saber: Departamento de Administração (Finanças e Orçamento e Serviços Gerais); Departamento de Convênios Ambulatoriais - DECAN (responsável pela execução e acompanhamento de convênios com outras instituições de saúde que fazem eventual atendimento complementar aos usuários do IAMSPE, e pelo funcionamento das 14 unidades ambulatoriais existentes em cidades de médio porte do interior do Estado) e, finalmente, o Departamento do Hospital (Hospital do Servidor Público do Estado - HSPE), sobre o qual recai a maior parte $(90 \%)$ do orçamento anual de, aproximadamente, cem milhóes de dólares americanos, seja para custeio direto, seja para investimentos. 
Essa estrutura administrativa foi formada em 1970, ano da aprovação do Regimento da Autarquia pela Assembléia Legislativa do Estado. Elaborado no contexto político-social e de assistência médica daquela época, o Regimento - ainda vigente é altamente centralizador e autoritário, na medida em que possibilita plenos poderes gerenciais ao Superintendente da autarquia (de indicação direta do Governador), que dispõe da escolha direta de todos os cargos de direção e chefias. Por outro lado, inexistem, regimentalmente, órgăos colegiados deliberativos, ou mesmo consultivos, que fiscalizem ou opinem sobre as diretrizes administrativas da Instituição. A assistência médica foi concebida, como era modelo na época, à população específica de funcionários públicos estaduais e seus dependentes (ascendentes ou descendentes).

Na composição das receitas orçamentárias, ao longo do ano, pode-se afirmar que, na média, $50 \%$ têm origem na contribuição (compulsória) de $2 \%$ dos vencimentos do servidor público, e a outra metade vem de verbas do Tesouro do Estado.

O HSPD, principal departamento do IAMSPE, constitui-se num complexo hospitalar de grande porte (95 mil metros quadrados erigidos numa área de 42 mil metros quadrados de terreno), com capacidade instalada de mil leitos. Ao longo de sua história e pela capacidade técnica dos seus profissionais de saúde, o Hospital incorporou novas tecnologias, ampliando a capacidade de atendimento subespecializado de alta complexidade, além de continuar prestando serviços com níveis de complexidade secundária e, até mesmo, primária.

A população potencialmente usuária do lAMSPE (funcionários públicos e seus dependentes) é estimada hoje em dois milhöes e quatrocentas mil pessoas. Deste contingente, $65 \%$ residem na capital ou na Grande Săo Paulo. $O$ estudo da origem da demanda ao HSPE mostra que seus usuários sāo funcionários públicos ou dependentes (98\%), sendo os $2 \%$ restantes pacientes classificados como de "interesse científico" pelos serviços médicos ou odontológicos, e outros provenientes de Programas da Secretaria de Estado da Saúde, como, por exemplo, a internação de pacientes com AIDS.

Os serviços ambulatoriais e de internação contabilizam cerca de três mil e quinhentos atendimentos diários, sendo que $92 \%$ têm origem na capital ou na Grande São Paulo, e apenas $8 \%$ vêm do interior.

Examinando-se a distribuição por faixa etária, depreende-se que a maioria dos pacientes atendidos (52\%) apresenta-se nos grupos de maiores de 45 , o que torna muito útil o Serviço de Atendimento Domiciliar, cujas equipes multiprofissionais acompanham, no domicílio, mais setecentos usuários.

Os pacientes do HSPE senvem-se dos serviços de 3.547 funcionários que representam cerca de $65,7 \%$ do total de 5.400 que compöem o corpo funcional do IAMSPE, sendo quase todos de regime celetista. A distribuição do quadro de funcionários do HSPE, num corte efetuado ao final do primeiro semestre de 1990 mostrava: 1.106 médicos; 236 enfermeiras; 709 auxiliares de enfermagem; 289 técnicos de outras modalidades e $\mathbf{8 0 0}$ profissionais de serviços gerais.

Os funcionários são representados por quatro associaçōes, a saber: Associação dos Médicos do laMSPE (AMIAMSPE); Associação dos Funcionários do lAMSPE (AFIAMSPE); Associação dos Enfermeiros do IAMSPE e Associação dos Farmacêuticos dos IAMSPE. 
Além destas características institucionais descritas, resta apontar que os usuários, desde 1983 (por ocasião da posse dos primeiros governos estaduais escolhidos por eleições diretas após o regime de ditadura militar), compōem a chamada Comissão Consultiva Mista (CCM), onde têm assento 66 associaçōes e sindicatos representativos das diferentes categorias do funcionalismo estadual.

Nas reuniões de periodicidade mensal, os usuários trazem suas demandas em relação aos serviços prestados pela instituição e têm a oportunidade de debater os problemas não somente com a administração como também com as entidades representativas dos trabalhadores do lAMSPE, também membros da CCM.

\section{Caracterizaçāo do Contexto Político e seus Reflexos na Instituição}

O IAMSPE nasceu a partir de reivindicaçôes dos servidores públicos estaduais e foi criado por lei, ainda como Departamento de Assistência Médica, no início dos anos 50. Ao final da década de 50, iniciam-se as obras de construção do Hospital do Servidor Público do Estado, inaugurado nos primeiros anos da década de 60 . O corpo clínico que organiza os serviços nas diferentes especialidades e subespecialidades médicas origina-se, na sua maior parcela, de professores oriundos da faculdade de medicina da USP que, naquela ocasiäo, encontravam obstáculos de ordem estrutural para alcançar maior desenvolvimento em suas carreiras docentes. Assim é que o HSPE pôde alcançar, ao final dos anos $60 \mathrm{e}$ início da década seguinte, seu apogeu técnico-científico, tanto no que se refere à prestação de assistência médica de ponta, como pela excelência da Residência Médica, oferecida a egressos das faculdades de todo o País, e até mesmo do exterior. (Aliás, o HSPD ainda procura, hoje em dia, essa sua 'vocação' e vem oferecendo cursos de pós-graduação, stricto sensu, em algumas áreas específicas, assim como desenvolve alguns serviços com tecnologia de alta complexidade).

Esse grande complexo hospitalar, dotado de reconhecida capacitação técnicocientífica e de formação de recursos humanos, sofre, como todos os setores da sociedade brasileira, as conseqüências do regime autoritário e os resultados desastrosos de administraçōes descompromissadas com as atividades e os objetivos da Instituição. Assim é que, paulatina mas inexoravelmente, ocorre o 'sucateamento' dos recursos materiais existentes, a desorganização administrativa e gerencial e, principalmente, a desmotivação da força de trabalho.

Esses fatos são agravados no período em que a Superintendência do IAMSPE foi ocupada por um coronel-médico indicado pelo último governador do Estado escolhido pelo regime militar. A dissociação de interesses entre a administração e os funcionários da Instituição, associada à ausência de diretrizes e metas administrativas e o modus operandi autoritário daquela superintendência, segundo o depoimento dos que vivenciaram aquele período, serviu de excelente meio para fomentar o corporativismo, propiciar o aparecimento de lideranças políticas locais e desestruturar as atividades administrativas.

Neste cenário ocorrem a chamada 'abertura política' e as primeiras eleições diretas para o Governo estadual (1983). Respondendo às reivindicaçôes dos servidores da Instituição e de seus usuários, o Governo do Estado permite que os dirigentes dos 
diferentes setores da autarquia sejam eleitos diretamente por seus pares. Dessa forma são escolhidos desde o Superintendente até os encarregados de setor, em composições políticas internas frágeis ou até inexistentes, levando a administração a perder de vista o objetivo maior da instituição, que é a assistência à saúde da população usuária. A perda de padrões administrativos, substituídos por práticas de interesse imediato e corporativo, ocasionou, dentre outros aspectos, o aparecimento de 'remendos' em situaçōes de trabalho (e. g. 'horas extras' permanentes), que geraram processos na Justiça do Trabalho, além do surgimento de movimentos grevistas, muitos dos quais originados por disputas internas de poder, além daqueles de natureza eminentemente político-partidária.

Todos esses fatores contribuíram para o decréscimo da capacidade de produção da Instituição e para com o descaso da sua atividade-fim. Nesse contexto ocorreu também o surgimento da CCM, já citada, fórum no qual os conflitos existentes entre os prestadores, os usuários e a administração eram evidenciados, mostrando que os interesses próprios de cada uma das partes, procurava prevalecer sobre os objetivos maiores da instituição.

Os resultados advindos dessa situação podem ser sintetizados em dois pontos principais: alta entropia administrativa e grave crise institucional.

Neste contexto, quase um ano após a posse do novo Governo Estadual, e em um período de mais de trinta dias de greve, que se seguiu a um dos momentos mais agudos da crise, inadequadamente administrada pelos dirigentes da Instituição (indicados de comum acordo entre os funcionários do IAMSPE e o Governo estadual), o Governador resolve substituir aquela administração, indicando o nosso nome para tal fim.

Desse modo, no final de fevereiro de 1988 tomamos posse, e as manchetes dos jornais da época retratam fielmente este relato:

"Campanha tenta salvar hospital" (O Estado de S. Paulo, 27/11/87);

"Secretário visita hospital em greve e afasta superintendente" (Folha de S. Paulo, 24/02/88);

"Protesto na posse do novo superintendente" (Folha da Tarde, 25/02/88);

"Manifesto - intervenção no IAMSPE" (assinado pela AMIAMSPE, AFIAMSPE, com apoio das entidades CREMESP (Conselho Regional de Medicina-SP); Associação Paulista de Medicina e Sindicato dos Médicos de São Paulo).

Como pode ser depreendido dessas notícias, as associaçōes dos servidores do IAMSPE entenderam nossa nomeação como mais um processo intervencionista espúrio pelo qual passava aquela autarquia, comparando-o ao que ocorrera anteriormente na ocasião do regime autoritário.

Com esse clima, nossa administração negociou o fim da greve com as lideranças locais e tentou imprimir diretrizes administrativas mais claras para resgatar, primordialmente, a confiabilidade entre os três segmentos da instituição - servidores, administração e usuários. Neste sentido, tentamos a manutenção do diretor do HSPE da administração anterior, procurando estabelecer um trabalho mais próximo do corpo diretivo do Departamento de Hospital, por meio de reuniōes semanais para traçar estratégias de ação no âmbito do Hospital. 
Da mesma maneira, reuníamo-nos, semanalmente, com as lideranças das associaçōes locais, para tentar resolver os problemas, sempre dentro do objetivo maior da instituição, qual seja, o atendimento das demandas de saúde da população usuária.

Essas tentativas foram, entretanto, infrutíferas, visto que, em maio daquele ano, o então diretor do Hospital escreve e distribui aos usuários, via associação dos médicos, um manifesto que coloca em dúvida os planos e os atos que a nova administração do IAMSPE vinha executando. Com isso ocorre a inevitável demissão da diretoria do Departamento de Hospital, e a nomeação, após alguns dias, de um diretor (DBJ) da mais estrita confiança do Superintendente (JCRO), e também não pertencente aos quadros do HSPE, originariamente.

Deve ser ainda apontado que, antes da posse do novo diretor do HSPE (ocorrida em 01/06/88), a Superintendência recebe um relatório da visita de inspeção que representantes do CREMES, da Comissão de Ética do HSPE, do Conselho Regional de Enfermagem e da Comissão Permanente de Saúde da Assembléia Legislativa de São Paulo fizeram às instalações do HSPE, quando constataram vários problemas.

Cabe aqui o seguinte esclarecimento: a seqüência de eventos políticos pelos quais passou o IAMSPE, principalmente os decorrentes da época do regime militar, provocou, conforme já explicado, o surgimento de lideranças políticas, que, depois, assumiram cargos diretivos nos diferentes órgãos de classe profissionais. Assim é que o então presidente do CREMESP era médico da instituição, que também tinha enfermeiras na direção do conselho regional da categoria. Os dirigentes da AFIAMSPE são hoje diretores do Sindicato dos Trabalhadores da Saúde do Estado de São Paulo; dois deputados estaduais, eleitos no último pleito, eram dirigentes da AMIAMSPE, assim como o atual presidente do CREMESP e outros dirigentes de centrais sindicais têm origem nos quadros da autarquia. Portanto, o grau de politização e organização dos quadros do IAMSPE era, e é, um dos mais elevados dentre os órgãos públicos do Estado.

Todos esses elementos político-culturais foram compreendidos e, principalmente, considerados como embasamento para implantação de estratégias concebidas dentro de princípios democráticos de gestão e de defesa da coisa pública.

Com tais princípios, nossa administração procurou traçar objetivos definidos de recuperação da Instituição, tanto em seus aspectos físicos e organizacionais como, fundamentalmente, nos aspectos relacionados aos seus recursos humanos. É neste ponto que começa a ser delineada a necessidade de instituição de um fórum para negociação permanente, entre administração e os trabalhadores do lAMSPE, capaz de equacionar os conflitos naturais decorrentes das suas relações de trabalho, antes da sua transformação em confrontos indesejáveis.

\section{O Sistema Permanente de Negociação Coletiva de Trabalho no IAMSPE}

Conforme demonstrado no item anterior, o grau de conflito entre administração e prestadores (e, também, usuários), já bastante elevado nos serviços de atenção à saúde, estava extremamente agravado pelas condiçōes descritas. É óbvio 
que isso afetava, ao lado de outros fatores de ordem estrutural, a qualidade dos serviços prestados. Neste sentido, a estratégia concebida procurou buscar instrumento que permitisse soluções negociadas, de caráter coletivo, segundo os interesses das partes, contrapondo-se às soluçōes autoritárias ou judiciais, mas sempre respeitando o interesse do usuário.

Dentro dessa concepção básica, a administração convidou para participar da elaboração e da implantação do projeto um profissional com experiência na área e que fosse aceito por ambas as partes. Sem vínculo empregatício ou qualquer outra forma de remuneração com a instituição, um advogado com experiência nas áreas administrativa e trabalhista e conhecedor de mecanismos de negociação coletiva no setor público em países da Europa, Douglas Gerson Braga foi consensualmente acatado como coordenador do processo.

O sistema negocial, iniciado neste período de confronto aberto entre as entidades dos servidores e a administração local, não seguiu qualquer modelo previamente fixado. Havia, ab initio, a disposição de se celebrar convênios coletivos de trabalho resultantes da negociação direta.

Após aproximadamente seis meses de avaliações prévias, durante os quais algum grau de confiabilidade entre as partes pode ser estabelecido, foi instalada a Mesa de Negociação Coletiva de Trabalho, formada por representantes das entidades locais dos trabalhadores e da administração. As reuniões, de periodicidade semanal, eram coordenadas pelo advogado já referido e secretariadas por uma funcionária do IAMSPE, indicada pelas entidades e aceita pela administração.

A primeira preocupação da Mesa foi a de estabelecer e demonstrar a eficiência do processo negocial, cujos resultados eram obtidos, sempre, de modo consensual. Os limites das negociações eram os estabelecidos pelas competências cabíveis à superintendência da autarquia estadual, além, é claro, daqueles definidos pelos princípios e normas constitucionais e do Direito. Destarte, estabeleceu-se a criação de instrumento que tivesse impacto político no resgate da confiabilidade entre servidores e administração (transparência), e que fosse dotado de 'fundamental importância jurídica' (formalização imediata de direitos e obrigações).

Foram criados, assim, os Protocolos da Mesa de Negociação, que têm caráter normativo, prazo indeterminado e somente podem ser revogados por vontade das partes. Durante o primeiro ano de funcionamento do processo, foram estabelecidos 14 protocolos, que constituíram o primeiro Acordo Coletivo de Trabalho no Setor Público do País, cujo conteúdo passou a fazer parte integrante dos contratos individuais de trabalho, tanto dos trabalhadores, como dos demais componentes dos grupos homogêneos.

A simples citação de alguns desses protocolos permitirá ao leitor estabelecer o alcance do Sistema Permanente de Negociação Coletiva de Trabalho no âmbito da organização administrativa e das conquistas sociais dos trabalhadores: critério de cálculo de horas suplementares; interpretação de normas constitucionais (p.ex., licença gestante; critérios para acordos em reclamação trabalhista; normas de segurança e medicina do trabalho; garantias relativas à demissão imotivada; exercício de liberdades sindicais; critérios de cálculos de horas e distribuição de plantões e obrigações 
relacionadas às atividades de pronto-socorro; criação da Comissăo Processante Permanente, cujo princípio básico é o direito do contraditório, com defesa assegurada ao(s) indiciado(s), entre outros.

O Sistema Permanente de Negociação Coletiva de Trabalho apresenta, então, as seguintes características:

- Componentes. A Mesa de Negociação, formada por representantes das partes, estabelece protocolos através de consenso. Tais protocolos comporão os Acordos Coletivos de Trabalho, assinados anualmente, e que passam a fazer parte integrante dos contratos individuais de trabalho. Em todo e qualquer caso a ser apresentado para discussão e o estabelecimento do acorda consensual, o interesse dos usuários da Instituição é 'sempre' prioritário.

- Princípios. Como em todo sistema de natureza contratual, existem princípios do Direito Constitucional e normas da esfera do Direito Trabalhista e da Administração Pública que devem ser respeitadas, servindo como limites para o Sistema. Neste sentido, eventuais condiçōes que ferem a ordem pública, os princípios da moral e da legalidade, a liberdade sindical, as normas de proteção ao trabalho não podem ser estabelecidas por quaisquer instrumentos de acordo coletivo. Por outro lado, em se tratando de órgão público, há que se observar a supremacia do interesse público sobre o particular e os acordos deverão ser, sempre, oficializados através de ato normativo da autoridade competente (portaria, decreto etc.), para que seja respeitada a indisponibilidade do interesse público.

- Bases legais para o setor público. Existe, ainda, discussão dos aspectos jurídicos relacionados à negociação coletiva de trabalho no setor público. A instalação do processo no lAMSPE baseou-se no princípio constitucional da livre associação sindical aos servidores civis do setor público (artigo 37 , inciso $\mathrm{Vl}$ ), reafirmado no artigo 115 , inciso VI da Constituição paulista promulgada em 1989.

(Como se trata de matéria específica de ordem jurídica recomendamos a leitura dos trabalhos de Douglas Gerson Braga publicados nos Cadernos da CUT: Jurídico e Relações Sindicais, números 3 e 4, de 1990 e o aprofundado estudo jurídico apresentado à OPAS, em 1992, "Recursos Humanos e Negociação Coletiva no Setor Público", de autoria das professoras Maria Paula Dallari Buca e Valéria S. L. Fonseca, da Faculdade de Saúde Pública da USP. Estes trabalhos concluem que, tanto do ponto de vista constitucional como do legal, a negociação coletiva de trabalho é auto-aplicável no setor público, desde que os princípios anteriormente enunciados sejam respeitados).

\section{Reflexos e Resultados}

Os principais reflexos decorrentes da implantação do Sistema Permanente de Negociação Coletiva de Trabalho no IASMPE podem ser assim enumerados:

- Definição clara dos papéis da administração e das entidades de classe. Nos últimos anos, houve confusão e mistura de papéis entre entidades de classe e administração, cujos 
componentes passaram a responder quase sem distinção e, com permissividade corporativa, pelos destinos do órgão. $O$ processo de negociação coletiva devolveu cada uma das partes a seu campo de atuação, permitindo à administração maior lucidez, balizando suas decisões também pelas ponderações levadas pelas entidades à mesa de negociação, sem perder de vista o interesse do usuário.

Desse modo, de maneira lógica e com um mínimo de resistência, podem-se modificar fluxos e reimplantar sistemas de atendimento ao público, alterar escalas de trabalho, reestruturar escalas de plantão e desfazer preconceitos relacionados à questão 'direitos adquiridos versus obrigaçôes contratadas'.

O exemplo mais significativo deste aspecto pode ser visto nos protocolos relativos ao rescalonamento de médicos em jornadas extraordinárias para o atendimento de porta do hospital. Estes profissionais, há anos, recebiam 'horas extras' sob a denominação SISPLAN. No decorrer do tempo, a atividade desenvolvida dentro desta jornada foi desvirtuada e fugiu ao controle administrativo. De forma preconceituosa e erroneamente interpretada era defendido o direito do médico continuar a receber estas horas ('direito adquirido'), mas sem se responsabilizar pelo cumprimento da jornada da escala a que estava submetido pela administração ('obrigação contratada'). Esta discussão durou anos na instituição e foi solucionada em dias na mesa de negociação. Nenhuma das partes perdeu. Ao contrário, os médicos incorporaram benefícios aos seus vencimentos, a administração conseguiu reimplantar o Pronto-Atendimento sem problemas nas escalas e o usuário viu seu atendimento substancialmente melhorado por redução do tempo de espera para ser atendido, com alívio da sobrecarga que havia no serviço de Pronto Socorro.

- Maior velocidade na resolução de conflitos trabalhistas, diminuindo a ingerência do Poder Judiciário. Nas situações de inequívoca favorabilidade jurídica ao funcionário, o Sistema permitia a imediata incorporação do benefício, sem ter que se aguardar a natural morosidade do sistema jurídico trabalhista. De fato, na ausência da mesa de negociação, o tempo decorrido entre a existência do fato e o julgamento trabalhista impedia que o benefício incorporado fosse traduzido em produção ou melhoria de qualidade no atendimento ao paciente. A questão, rapidamente resolvida pela negociação, permitia que a administração trabalhasse a satisfação do benefício imediatamente incorporado em proveito do atendimento ao usuário. É evidente que para as lideranças políticas locais o saldo positivo era também traduzido sob a forma de credibilidade política.

- Consolidação dos avanços políticos e administrativos. Desde que os direitos e as obrigações contratuais acordadas no Sistema passavam a fazer parte integrante dos contratos individuais de trabalho, e também eram oficializados por atos normativos (portarias) do Superintendente, os avanços assim conseguidos viam-se perfeitamente consolidados. 
- Liberdade e autonomia sindical e da administração. O acordo firmado pelas partes referentes a este tópico não somente estabelecia a liberdade de atuação sindical, apontando os limites operacionais para as ações das entidades representativas dos trabalhadores, respeitando-se os direitos dos usuários, como também tornava indiscutível o direito da administração em realizar atos de sua competência, sem necessariamente atrelá-los à mesa de negociação, que nunca poderia ser confundida com o indesejável sentido de eventual co-gestão.

- Instrumento mediador de conflito e de estabelecimento de equilíbrio político. Além dos exemplos já relatados e que são emblemáticos no sentido da mediação de conflitos, vale ressaltar que, durante o transcorrer do processo negocial, as entidades políticas locais, de forte capacitação política como já foi colocado, participaram da organização e da deflagração de movimentos grevistas em relação aos níveis salariais, cuja competência extrapola o âmbito da autarquia. Este aspecto deve ser assinalado em razão de que o sistema negocial implantado resolvia ou equacionava as situações dos conflitos locais, estabelecendo, dessa forma, um equilíbrio político que, apesar de toda a situação de confronto existente por ocasião da nossa posse, pode se manifestar já a partir do sexto mês de gestão.

É oportuno relatar também o depoimento que as lideranças da AMIAMSPE e da AFIAMSPE estamparam no encarte 'Informe Sindical', publicado no Jornal do Brasil, edição de 25/03/91: "A negociação é a grande responsável por essa situação (...diminuição do número de greves motivadas por más condições de trabalho...). Semanalmente quando nos reunimos e os problemas são colocados, nos antecipamos ao confronto", observa Regina Ribeiro Parizzi Carvalho, presidente da Associação dos Médicos do IAMSPE. Além disso, "para cada direito adquirido na negociação, estamos aceitando uma nova obrigação. Não exageramos nas reivindicações porque sabemos que isso amplia o impasse, com o qual estávamos acostumados a conviver", afirma a sindicalista Célia Regina Costa, da AFIAMSPE.

Estas afirmativas comprovam cabalmente a eficácia do instrumento de negociação permanente como de grande utilidade no trato dos recursos humanos e das relações de trabalho da Instituição, principalmente levando em consideração toda a contextualização política em que o processo se realizou. No entanto, além desses aspectos extremamente importantes como resultados positivos da iniciativa, cabe demonstrar algum indicadores da produção hospitalar que mostram os reflexos ocorridos após a implementação do Sistema Permanente de Negociação Coletiva de Trabalho. 


\begin{tabular}{|c|c|c|c|c|}
\hline INDICADORES & 1987 & 1988 & 1989 & 1990 \\
\hline \multicolumn{5}{|l|}{ INTERNAÇŌES } \\
\hline Leitos disponiveis & 1.007 & 947 & 928 & 880 \\
\hline Taxa média de ocupação & 60,91 & 71,05 & 74,80 & 78,43 \\
\hline Média de permanência & 10,94 & 10,59 & 10,67 & 111,00 \\
\hline Número de internações & 23.777 & 23.074 & 23.597 & 22.710 \\
\hline $\begin{array}{l}\text { Média mensal } \\
\text { Paciente/Leito }\end{array}$ & 2,36 & 2,43 & 2,54 & 2,58 \\
\hline \multicolumn{5}{|l|}{ AMBULATORIAIS } \\
\hline Consultas & 481.359 & 403.482 & 403.343 & 457.247 \\
\hline Cirurgias & 21.654 & 25.045 & 29.307 & 33.734 \\
\hline Total & 503.013 & 428.527 & 432.650 & 490.971 \\
\hline \multicolumn{5}{|l|}{ SISTEMA-PORTA } \\
\hline Pronto-socorro & 115.815 & 129.567 & 117.156 & 112.812 \\
\hline Pronto atendimento & - & - & 58.561 & 77.459 \\
\hline Total & 115.815 & 129.567 & 175.717 & 190.271 \\
\hline \multicolumn{5}{|l|}{ OUTROS } \\
\hline Atendimento domiciliar & 6.804 & 6.444 & 7.584 & 8.100 \\
\hline Hospital retaguarda & 816 & 732 & 1.248 & 1.440 \\
\hline
\end{tabular}

Para a análise dos dados apresentados, vale lembrar, conforme já assinalado anteriormente, que o processo de negociação teve seu início efetivo a partir de janeiro de 1989. Além disso, em razão do sucateamento da área física, deteriorada ao longo dos anos, sem nunca ter havido a preocupação de uma reforma substancial, iniciou-se em agosto de 1988 uma ampla reforma do Hospital, o que obrigou a uma redução da área física de $40 \%$ nos setores ambulatoriais e a exclusão de cem leitos nas áreas de internação.

A análise dos dados de produção mostra, no geral, um incremento importante nas atividades-fim do IAMSPE, especialmente considerando-se a diminuição do espaço operacional apontado. $\mathrm{Na}$ área de internação, mesmo com a diminuição de, aproximadamente, $10 \%$ dos leitos disponíveis no período, houve um acréscimo na utilização mensal de pacientes por leito.

O impacto mais evidente, no entanto, é mostrado pelos resultados das áreas ambulatoriais e do sistema-porta. Com cerca de $40 \%$ da área útil desativada a partir de 1988, ocorre uma elevação global de $10 \%$ no atendimento de pacientes externos do HSPE. Note-se, ainda mais, que o número desses atendimentos sofre a mais significativa elevação nos anos de vigência do Sistema de Negociação (1989-1990).

O mesmo fenômeno ocorre, também de maneira bastante significativa, nos dois outros sistemas de retaguarda hospitalar do IAMSPE - Assistência Domiciliar, com crescimento de quase $18 \%$, e encaminhamento para o hospital de retaguarda que 
aumenta cerca de $75 \%$. Ressalte-se que esses dois serviços dependem de equipes profissionais multidisciplinares, além do apoio dos funcionários dos serviços gerais, especialmente do setor de transportes.

É evidente que esses resultados de aumento na produção das àtividades de atenção à saúde do usuário do HSPD dependeu, também, de outros fatores, especialmente aqueles relacionados à reorganização administrativa. No entanto, como a atenção à saúde, especialmente aquela de âmbito hospitalar, é atividade de prestação de serviço e depende, por essa razão, da fundamental participação dos recursos humanos em todos os seus níveis, sejam os diretos, sejam os indiretamente ligados ao atendimento do público, fica evidente que o Sistema Permanente de Negociação Coletiva de Trabalho exerceu um papel primordial e inquestionável nesse sentido.

\section{Conclusāo}

O conceito de gerência pode ser entendido como a "a arte de pensar, decidir e agir para a obtenção de resultados, mas somente alcançados através de pessoas e numa interação constante" (Motta).

Assim é essencial definir, uma política de recursos humanos voltada para o atendimento dos processos envolvidos nas relações de trabalho e no trabalho, em que os recursos humanos sejam administrados como o principal patrimônio do sistema, sendo a atividade-meio imprescindivel para a produção dos serviços de saúde e os agentes incontestes dos processos de produção. Fica evidente que uma permanente negociação entre administração e trabalhadores, com regras básicas bem estabelecidas e acatadas por ambas as partes, significa um instrumento de grande competência.

À parte das discussōes de natureza jurídica já apontadas, queremos ressaltar, como administradores de equipamentos e sistemas de saúde que a Negociação Coletiva de Trabalho no setor público, exemplificada neste caso do IAMSPE, é um instrumento que:

- agrega os servidores ao próprio serviço, envolvendo-os na responsabilidade pela sua organização e resultados;

- encaminha problemas com disposição de conquistar soluções de 'dupla mão' entre a administração e seus recursos humanos, estabelecendo níveis adequados nas relaçōes de trabalho, longe de significar um simples atendimento de reivindicaçōes ou mecanismo de co-gestão;

- apresenta um caráter 'pedagógico' do ponto de vista administrativo e sindical, contribuindo, de um lado, para a diminuição das atitudes autocráticas, e de outro, para atenuar a força de reivindicações de cunho exclusivamente corporativo;

- reflete-se positivamente na qualidade das atividades meio e nos resultados da produção dos serviços de saúde, e, finalmente;

- serve de meio administrativo competente para se alcançar os objetivos de uma gestão de qualidade total, gerando conseqüências práticas nos resultados de políticas de interesse público na área da saúde. 
Ao lado dessas conclusões, cabe assinalar, no entanto, que os limites determinados pela competência da autarquia, que somente pode atuar nos níveis de vencimento dos trabalhadores através de benefícios indiretos (também acordados na mesa de negociação), já que o salário e demais gratificaçōes são de competência de outras esferas de Governo, representou um obstáculo importante para um maior alcance desta iniciativa.

Por outro lado, a vontade política dos administradores da instituição em utilizar este instrumento gerencial de modo efetivo parece, ainda, ter grande importância. Neste sentido, quando um de nós (JCRO) participou de recente debate sobre o tema, ocorrido em outra autarquia estadual (SUCEN), foi informado de que está havendo dificuldades conjunturais para que a Mesa de Negociação volte a ter resultados como em nossa gestão. De fato, o boletim informativo assinado pela entidades representativas dos servidores do lAMSPE, datado de julho de 1992, aponta:

A Mesa de Negociação Permanente não vem cumprindo o seu papel e muitas das questōes apresentadas não são encaminhadas e outras nem são discutidas (...) O Acordo Coletivo de Trabalho firmado entre as entidades e a administração anterior na Mesa de Negociação Permanente representa um avanço na organização dos trabalhadores.

\section{Leituras Recomendadas}

- Sobre aspectos jurídicos e de organização de sistema de negociação coletiva de trabalho:

Convençöes da Organizaçäo Internacional do Trabalho, especialmente as de número 87,98 , 151 e 168 (esta sobre a Negociaçăo Coletiva de Trabalho na Administração Pública); Revista Legislação Trabalhista, 54 (3), mar.1990.

Proposta de Projeto de Lei sobre Contratação Coletiva de Trabalho. Cadernos da CUT: Jurídico e Relaçōes Sindicais, 4, 1990.

BRACA, D. C. O sistema permanente de negociação coletiva de trabalho no IAMSPE. Cadernos da CUT: Jurídico e Relaçồes Sindicais, 3, 1990.

BRACA Jr, D. Negociação Coletiva de Trabalho no Setor Público: uma análise de resultados. Cadernos da CUT: Jurídico e Relaçōes Sindicais, 4, 1990.

BUCA, M. P. D. \& FONSECA, V. S. L. Recursos Humanos e Negociação Coletiva de Trabalho no Setor Público. Estudo jurídico apresentado à OPAS, 1992.

- Sobre aspectos de gerenciamento geral e hospitalar:

NOVAES, H. M. \& PAGANINE, J. M. Garantia de Qualidade: a creditação de hospitais para América Latina e o Caribe. OPAS, FLSH. Série/Silos, 13, 1992.

SCHOLTES, P. et al. Times de Qualidade: como usar equipes para melhorar a qualidade. Qualitymark, 1992.

\section{Modelo Aprovado pelo Conselho Nacional de Saúde}

A regulação aprovada pelo Conselho Nacional de Saúde, reproduzida a seguir, e editada em Resolução pelo Ministro de Estado da Saúde, em 1993, foi também precedida de amplo debate e de recomendações e resoluções tomadas a partir das Conferências Nacionais de Saúde e de Recursos Humanos. 
Experiência pioneira, envolve diversos segmentos da sociedade e decisōes de organismos da mais alta legitimidade, tais como os mencionados. Na regulação, propóe-se sistema nacional de tratamento de conflitos envolvendo a União, os Estados e os Municípios, condizente, portanto, com a natureza do Sistema Único de Saúde.

\section{Resoluçāo $\mathrm{n}^{0}$ 52, de 6 de maio de $1993^{3}$}

O Plenário do Conselho Nacional de Saúde em sua Vigésima Quarta Reunião, realizada nos dias 5 e 6 de maio de 1993, e no uso de suas competências regimentais e nas atribuiçōes conferidas pela Lei no 8.142 , de 28 de dezembro de 1990 e pela Lei n 8.080, de 19 de setembro de 1990, considerando o documento Descentralização das Ações e Serviços de Saúde: a ousadia de cumprir e fazer cumprir a lei resolve:

1. Instituir urna Mesa Nacional de Negociação, com o objetivo de estabelecer um fórum permanente de negociação entre empregadores e trabalhadores do Sistema Único de Saúde (SUS) sobre todos os pontos pertinentes à força de trabalho em saúde.

2. Participam da Mesa Nacional de Negociaçăo 11 (onze) representantes dos empregadores públicos, divididos em 03 (três) do Ministério da Saúde, 03 (três) do Conselho Nacional de Secretários de Saúde (CONASS), 03 (três) do Conselho Nacional de Secretários Municipais de Saúde (CONASEMS), 01 (um) representante da Secretaria de Administração Federal (SAF), 01 (um) representante do Ministério da Educação e Desporto (MED) e 11 (onze) representantes das Entidades Sindicais do Setor.

3. Aos integrantes da Mesa caberá a formulação das normas de funcionamento da mesma, podendo, numa dinâmica de aperfeiçoamento do processo, serem convidados representantes internacionais com experiência em processos similares em seus países.

4. A pauta de negociação necessariamente conterá os itens:

a) salário: reposição, reajuste, isonomia;

b) jornada de trabalho no SUS;

c) carreira de Saúde;

d) direitos e conquistas sindicais nas reformas de estrutura no SUS;

e) mecanismos de gestão de Recursos Humanos no SUS.

Outros itens serão acrescidos à pauta, a critério dos integrantes da Mesa.

5. O Ministério da Saúde convocará em maio a Primeira Reunião, estabelecendo a partir de então os integrantes da Mesa o seu cronograma de reuniões.

\section{Resolução no 111 , de 9 de junho de $1994^{4}$}

O Plenário do Conselho Nacional de Saúde em sua Trigésima Sexta Reunião Ordinária, realizada nos dias 08 e 09 de junho de 1994, cumprindo suas atribuições regimentais, considerando a legislação civil vigente, particularmente o artigo 37 , inciso

3 Diário Oficial da União, 26/0/93.

4 Resoluçäo homologada pelo Ministro Henrique Santillo, nos termos do Decreto de Delegação de Competência, de 12/11/91. 
VI, e o artigo 8,inciso VI da Constituição Federal, as Recomendaçōes e Resoluções das Conferências Nacionais de Saúde e da Conferência Nacional de Recursos Humanos e a Resolução no 52 do Conselho Nacional de Saúde, de 06 de maio de 1993, resolve:

1. Propor aos Estados e Municípios a implantação de Mesas de Negociação, compostas de forma paritária entre empregadores e trabalhadores, à semelhança da Mesa Nacional de Negociação;

2. O Conselho de Saúde nessa esfera de governo deverá acompanhar e estimular essa implantação, contribuindo assim para a criação de um espaço fundamental para melhoria das relações empregadores-trabalhadores, no âmbito do SUS.

\title{
Regimento da Mesa Nacional de Negociação - sus ${ }^{5}$
}

\author{
Título ! \\ Da Organização \\ Capítulo I \\ Dos Objetivos
}

Art. 19. A Mesa Nacional de Negociação instituída pela Resolução no 52 do Conselho Nacional de Saúde, de 6 de maio de 1993, publicada no Diário Oficial da União de 26 de maio de 1993, tem por finalidade estabelecer um fórum permanente de negociação entre empregadores e trabalhadores do Sistema Único de Saúde (SUS) sobre todos os pontos pertinentes à força de trabalho em saúde, visando a:

a) melhorar as condições de trabalho e o relacionamento hierárquico dentro das instituições públicas do setor, em cada esfera de governo;

b) melhorar o desempenho e a eficácia profissional dos quadros funcionais e, portanto, a resolutividade dos serviços prestados à população, assegurando a valorização e capacitação profissionais, buscando viabilizar as condições necessárias ao efetivo funcionamento do SUS;

c) promover cooperação técnica dos Estados, Distrito Federal e Municípios, na implementação do processo de negociação coletiva de trabalho sempre que solicitado.

Parágrafo Único. A fixação dos objetivos comuns definidos neste artigo justifica-se pelas seguintes consideraçōes:

a) a finalidade exclusivamente social do órgão público;

b) necessidade de se adequar os interesses dos trabalhadores da saúde às atividades finalísticas do SUS, consubstanciadas na prestação de senviços de qualidade aos usuários;

c) entendimento de que, dada a natureza de relevância pública dos seniços de saúde, a execução dessas açōes não ocorre adequadamente sem que haja empenho e eficiência profissional de todos aqueles que nelas estejam, direta ou indiretamente, envolvidos.

5 Versão com as modificações da reunião de 03/05/94. 


\section{Capítulo II \\ Dos Integrantes}

Art. 22. Participam da Mesa Nacional de Negociação 11 (onze) representantes dos empregadores públicos, dividindo-se em 03 (três) do Ministério da Saúde, 03 (três) do Conselho Nacional de Secretários de Saúde (CONASS), 03 (três) do Conselho Nacional de Secretários Municipais de Saúde (CONASEMS), 01 (um) representante da Secretaria de Administração Federal (SAF), 01 (um) representante do Ministério da Educação e do Desporto (MEC) e 11 (onze) representantes das entidades sindicais do setor.

$\$ 1^{0}$. Aos integrantes da Mesa caberá a formulação das normas de funcionamento da mesa, podendo, numa dinâmica de aperfeiçoamento do processo, serem convidados representantes nacionais $\mathbf{e}$ internacionais com experiências em atividades similares.

$\S 2^{\circ}$. Os integrantes e respectivos suplentes da Mesa Nacional de Negociação serão indicados por suas representações à Coordenação Geral do Conselho Nacional de Saúde, que providenciará os atos formais de designação.

\section{Capítulo III \\ Da Pauta de Negociação}

Art. 3․ O temário e respectivo cronograma de reunióes do processo de negociação serão selecionados e definidos pelos integrantes da Mesa Nacional de Negociação, incluindo assuntos conflitantes entre as partes ou que afetem a resolutividade dos serviços de saúde prestados à população, cuja pauta deverá necessariamente conter os seguintes itens:

a) salário: reposiçăo, reajuste, isonomia;

b) jornada de trabatho no SUS;

c) carreira de saúde;

d) direitos e conquistas sindicais nas reformas de estrutura no SUS;

e) mecanismos de gestão de Recursos Humanos no SUS.

Parágrafo Único. Outros itens serão acrescidos à pauta a critério dos integrantes da Mesa.

\section{Capítulo IV \\ Da Fundamentação Legal}

Art. $4^{\circ}$. A Mesa Nacional de Negociação constituiu-se em um instrumento negocial que observa a legislação civil vigente e fundamenta-se nos seguintes dispositivos legais:

- Constituição Federal, Artigo $37^{\circ}$ - VI: "é garantido ao servidor público civil o direito a livre negociação sindical";

- Constituição Federal, Artigo $8^{Q}$ - VI: "é obrigatória a participação dos sindicatos nas negociações coletivas de trabalho"; 
- Recomendações e Resoluções das Conferências Nacionais de Saúde, do Conselho Nacional de Saúde e da II Conferência Nacional de Recursos Humanos para a Saúde;

- Resolução n²52 do Conselho Nacional de Saúde, de 6 de maio de 1993.

\section{Capítulo V \\ Da Sistematização}

Art. 5․ As partes entendem que o instrumental mais adequado à consecução dos objetivos traçados é a adoção do Sistema Permanente de Negociação Coletiva de Trabalho, que significa:

a) o estabelecimento de processo de negociação coletiva livre, direta e permanente entre as partes interessadas;

b) a formalização, sempre que necessário, de acordos protocolares escritos, específicos e de caráter normativo.

Art. 6‥ A adoção deste Sistema, como instrumento para mediação de conflitos, implica o reconhecimento e a garantia dos seguintes princípios básicos:

a) liberdades sindicais: nos termos constitucionais, em seus aspectos organizativos e de exercício de atividade sindical;

b) autonomia de negociação: não ingerência de outros órgãos públicos ou de terceiros durante o processo de negociação, observando-se o princípio da indisponibilidade do interesse público;

c) racionalizaçăo da burocracia: adaptação da burocracia ao processo negocial, eliminação de excessos, agilidade na busca de soluções, agilidade na execução de medidas;

d) livre acesso à informação: as partes não podem se furtar a fornecer informações pertinentes à matéria negocial;

e) negociaçăo permanente: a parte está obrigada à negociação quando solicitada pela outra parte ou pela coordenação do sistema, mesmo em situações adversas, como greve e outras;

f) autonomia das partes: a administração buscará sempre a via negocial para tratamento de questões que envolvam o funcionalismo sem, contudo, deixar de dar cumprimento às suas responsabilidades e atribuiçōes administrativas. As entidades sindicais não têm responsabilidade administrativa, mantendo sua completa autonomia como entidade representativa dos interesses dos servidores;

g) equilíbrio político: a harmonia entre a autonomia de interesse e a consecução dos objetivos comuns repousa na sensibilidade política das partes para que o sistema resulte eficaz;

h) consulta aos interessados: viabilização de sistemática de consulta permanente aos usuários representados no Conselho Nacional de Saúde, para busca de soluçōes e de sugestões relativas a impasse no funcionamento do sistema. 
Art. 7ํ. As partes deverão recorrer aos princípios e objetivos definidos nos artigos anteriores como fonte de argumentação, sempre que houver impasse ou dificuldades conceituais.

Art. $8^{9}$. A distorção dos objetivos e a não observância dos princípios mencionados colocará em risco a existência do Sistema, devendo a responsabilidade ser imputada ao descumpridor.

\section{Título II \\ Do Funcionamento \\ Capítulo I \\ Da Composição da Mesa}

Art. 9‥ A Mesa Nacional de Negociação é constituída de forma paritária, na forma indicada no artigo 2 deste documento, sendo escolhidos entre os membros um Coordenador e um Secretário-Geral.

$\S 1^{\mathrm{O}}$. A critério da Mesa, poderão ser criados grupos de trabalho com objetivo de aprofundar estudos de matérias visando a subsidiar tecnicamente suas atividades, com prazo determinado de funcionamento.

$\$ 2 \%$. As partes poderão dispor de assessorias técnicas especializadas para as discussões de temas relevantes com intuito de dirimir dúvidas para consubstanciar decisões da Mesa.

Art. $10^{\circ}$. O Coordenador e o Secretário-Geral da Mesa Nacional de Negociação serão escolhidos e substituídos por decisăo dos integrantes da Mesa.

$\$ 7^{\circ}$. O Coordenador, o Secretário-Geral e outros membros integrantes da Mesa, servidores de instituiçōes públicas, serão liberados do trabalho para o exercício de suas atividades, sem prejuízo de qualquer natureza no seu órgão de origem.

$\S 2$. . As atribuições do Coordenador e do Secretário-Geral serão definidas de comum acordo pelas partes.

Art. 11․ A Secretaria Executiva do Ministério da Saúde oferecerá a infra-estrutura adequada ao funcionamento do Sistema, através do Conselho Nacional de Saúde, com o apoio da Coordenação Geral de Desenvolvimento de Recursos Humanos para o SUS e dos demais órgãos da estrutura organizacional do Ministério da Saúde.

\section{Capítulo II \\ Da Competência Material}

Art. $12^{\circ}$. A Mesa Nacional de Negociação tem, em princípio, competência para apreciar qualquer matéria a ela submetida que envolva, direta ou indiretamente, interesse das instituições e/ou dos trabalhadores. 


\section{Capítulo III \\ Dos Trâmites}

Art. 13‥ Qualquer das partes poderá apresentar reivindicações ou questões do interesse de suas representaçōes à Mesa Nacional de Negociação do SUS.

Art. 14\%. O processo negocial é permanente e a Mesa de Negociação deve se reunir nas datas previstas no cronograma de reunióes e extraordinariamente, quando solicitada convocação por uma das partes.

Art. $1^{2}$. Os assuntos tratados na Mesa de Negociação serão registrados de forma sintética $\mathrm{em}$ atas de reunião.

Art. 16‥ As reivindicações e questóes trazidas pelas partes deverăo ser sempre escritas.

Art. $17^{\circ}$. A contraparte, a quem é dirigida a questão, está obrigada a apresentar resposta de forma escrita, em prazo estabelecido preferencialmente de comum acordo, ou, não sendo possível, fixado pela Coordenação que não poderá ultrapassar a trinta dias, prorrogáveis por acordo das partes.

Art. $18^{\circ}$. Sempre que houver acordo sobre determinada matéria, este deverá ser formalizado através de Protocolo da Mesa Nacional de Negociação do SUS.

Art. 19․ Todos os documentos pertinentes ao processo negocial serão arquivados no Conselho Nacional de Saúde, onde estarão à disposição de qualquer interessado.

Art. 20․ Os atos, formalidades e procedimentos burocráticos estabelecidos neste e em outros capítulos serão dosados no sentido de auxiliar o processo negocial e não de inviabilizá-lo.

\section{Capítulo IV \\ Da Dinâmica das Reuniões}

Art. 21‥ A Mesa Nacional de Negociação do SUS observará, durante suas reuniōes oficiais ordinárias e extraordinárias, os seguintes princípios:

a) terão início com a presença mínima de $50 \%$ (cinqüenta por cento) mais 1 (um) de seus membros titulares ou respectivos suplentes, oficialmente designados;

b) os temas conflitantes que não sejam equacionados por consenso serão objeto de deliberação pela apuração de votos dos membros presentes à reunião, sendo considerada aprovada a que obtiver $3 / 4$ (três quartos) dos presentes;

c) serão realizadas, mensalmente, no dia imediatamente anterior às reuniōes do Conselho Nacional de Saúde, em caráter ordinário, e extraordinariamente, em data agendada de comum acordo entre as partes, para exame de temas inadiáveis;

d) a pauta das reuniöes ordinárias subseqüentes será definida ao término de cada reunião, sem prejuízo de novos pontos acordados;

e) a condução dos trabalhos estará a cargo do Coordenador auxiliado pelo Secretário-Geral, ambos designados na forma estabelecida no artigo 10 deste Regimento. Na ausência de qualquer um deles, os integrantes da Mesa escolherão seus respectivos substitutos para aquela reunião; 
f) a palavra será franqueada a participantes que não sejam membros efetivos e/ou suplentes somente quando convidados para se pronunciarem sobre temas específicos;

g) o Ministério da Saúde poderá viabilizar a presença dos membros da Mesa nas reuniões.

\author{
Título III \\ Da Formalizaçāo dos Acordos \\ Capítulo I \\ Da Capacidade das Partes
}

Art. 220. Os resultados advindos do presente sistema negocial dependem única e exclusivamente das partes, que, neste ato, declaram-se livres e aptas para negociar direitos e obrigações em nome de seus representados, observando o seguinte:

a) em relação às entidades sindicais, que haja aprovação e autorização dos interessados, manifestada em suas instâncias deliberativas, realizadas nos termos dos estatutos da respectiva entidade;

b) em relação aos empregadores integrantes da Mesa Nacional de Negociação, que tenham poder deliberativo consagrado no ato formal de sua designação.

Art. 23ㅇ․ Todas as resoluções da Mesa Nacional de Negociação serão implantadas no âmbito do SUS.

\title{
Capítulo II \\ Do Sistema Permanente de Negociação
}

Art. 240. A Mesa Nacional de Negociação do SUS tem vigência por tempo indeterminado.

Art. 25․ Nos termos da legislação vigente, da Constituiçăo da República e observados os preceitos ora fixados, as partes estabelecem, como instrumento negocial, o Protocolo da Mesa Nacional de Negociação.

Art. $26^{2}$. Os Protocolos da Mesa Nacional de Negociação são acordos coletivos de trabalho específicos sobre uma ou sobre um lote de reivindicaçōes, celebradas entre as entidades representativas do funcionalismo do SUS e suas administrações, nas três esferas de governo, com os seguintes atributos:

a) objeto: relações e condições de trabalho;

b) eficácia: caráter normativo, adere ao cargo ou emprego público como direito e/ou como obrigação; pode ser exigido judicialmente, de forma individual ou coletiva;

c) abrangência: depende da matéria negocial;

d) periodicidade: pode ser celebrado a qualquer tempo;

e) quantidade: não há limitação quanto ao número;

f) vigência: por prazo indeterminado, somente revogável por vontade das partes, através de outro instrumento negocial. 
Art. 270. Os casos omissos serão resolvidos pelas partes.

Art. $28^{\circ}$. Por entenderem que as disposições constantes neste documento expressam a soberana vontade das partes e de seus representados, aprovam o teor do presente instrumento da Mesa Nacional de Negociação.

\subsection{A NEGOCIAC̄̃̃O COLETIVA COM SUPORTE LEGISLATIVO NO MUNICÍPIO DE CAMPINAS}

Outra rica experiência no campo dos conflitos e das relaçöes de trabalho no setor público é relatada e analisada a seguir, diretamente por quem a protagonizou: o médico, diretor de Saúde do Município, Dr. David Braga Júnior. ${ }^{6} \mathrm{O}$ sistema adotado em Campinas (SP) envolve outro ator no cenário das negociações coletivas: o Poder Legislativo. Após o relato, encontram-se transcritos a lei e o decreto municipal editado pela prefeitura. ${ }^{7}$

\section{Introdução}

As relaçōes no trabalho no setor público são regidas por um Estatuto $\mathrm{e}$, complementarmente, por instrumentos normativos que são os Decretos, Portarias, Normas e Leis. Para os funcionários que não estão regidos pelo Estatuto existe um contrato que obedece à Consolidação das Leis do Trabalho (CLT), complementada pelas normas emanadas dos instrumentos já citados.

No entanto, na prática, os conflitos decorrentes das atividades cotidianas não conseguem ser resolvidos por esses instrumentos jurídico-burocráticos, colocando com muita freqüência a Administração e os servidores em posição de confronto.

A impossibilidade de resolver essas situaçōes acaba por provocar desmotivaçăo para os servidores e desgaste para a Administração. Qualquer que seja o resultado desses enfrentamentos, sempre acaba por causar prejuízo para os usuários que, além de clientes desses serviços, são, como cidadãos, os financiadores desses sistemas de serviços públicos.

Paralelamente, em decorrência da impropriedade dos instrumentos normativos (estatutos e contratos), para dar solução aos conflitos surge uma verdadeira 'indústria' que, pautada nesses mesmos atos, leva para os tribunais a suposta discussão e equacionamento dos desentendimentos decorrentes do processo de trabalho.

Procuradores dos órgãos públicos e advogados trabalhistas, vinculados ou năo aos sindicatos, desencadeiam verdadeiras avalanches de reclamações trabalhistas que atulham as Delegacias e os Tribunais do Trabalho.

6 À época do relato da experiência, David Braga Júnior era também presidente do Hospital Municipal Dr. Mario Gatti, no mesmo Município.

7 Este trabalho foi publicado na Revista da Organização Pan-Americana da Saúde/Organizaçāo Mundial da Saúde, Série Desenvolvimento de Recursos Humanos, 5, 1994, em que se abordou o tema "Perspectivas para o Gestão do Trabalho no Sistema Único de Saúde". 
Longe de resolver os conflitos gerados no processo de trabalho, as reclamações trabalhistas criam uma falsa expectativa de soluções que jamais ocorrem no tempo de evitar maiores prejuízos aos usuários dos serviços públicos.

Buscando redirecionar e encontrar formas alternativas de solução para esta inevitável fonte de conflitos cotidianos, e sem ferir os princípios da liberdade contratual, de proteção ao trabalho, da ordem pública, da moral, da liberdade sindical, da indisponibilidade do interesse público e da supremacia do interesse público sobre o interesse particular, realizamos, na Prefeitura de Campinas, uma mesa de negociação dentro de um Processo Permanente de Negociação Coletiva de Trabalho, que permitiu encontrar soluções rápidas para uma situação de conflito envolvendo os servidores da Secretaria Municipal de Saúde e do Hospital Municipal Dr. Mário Gatti com a Administração, durante o segundo semestre de 1992.

Este trabalho - redigido com o objetivo de, ao ser divulgado, propiciar aos gestores de sistemas ou de serviços públicos a visualização de alternativas para a difícil arte de administrar no setor público, com eficácia, eficiência, efetividade e eqüidade - não tem a pretensăo de ser estritamente científico, mas deverá indicar caminhos e facilitar o acesso às informações de ordem teórica, tão necessárias para manter os frágeis equilíbrios técnico-políticos que permeiam a organização dos nossos serviços públicos.

\section{Perfil do Município de Campinas}

O Município de Campinas está situado a $100 \mathrm{~km}$ da cidade de São Paulo, tem uma populaçăo de $\mathbf{8 5 0}$ mil habitantes e é pólo de influência para aproximadamente 1,5 milhão de pessoas, na região mais industrializada do interior do Estado de São Paulo.

A Prefeitura Municipal tem aproximadamente 11.000 servidores; 3.000 deles estão lotados na Secretaria Municipal de Saúde (SMS). A SMS conta com um órgão central e 46 unidades prestadoras de seniço ambulatorial: 40 Centros de Saúde e 6 unidades especializadas (um Hospital e Pronto-socorro com 120 leitos, um Laboratório de Patologia Clínica, um Centro de Vigilância, um Serviço de Controle de Zoonoses, um Almoxarifado e uma frota de ambulâncias).

Dentre os grandes municípios do Brasil, é um pólo importante de incorporação e divulgação de tecnologia, particularmente na área de Saúde Pública. O Município tem-se destacado pelos investimentos e pelo grau de organização que tem empreendido ao longo dos últimos 12 anos. É fonte de referência nacional nesta área para implementação do Sistema Único de Saúde (SUS).

\section{Um Pouco da História do Processo de Negociação Coletiva de Trabalho no Município}

A penúltima gestão municipal, iniciada em janeiro de 1989, eleita pelo Partido dos Trabalhadores (PT), teve como Prefeito um sindicalista e fundador do PT e da Central Única dos Trabalhadores (CUT). 
Nos dois primeiros anos da gestão, dentro do programa do PT, foram feitas algumas tentativas de instalar um processo de negociação coletiva e permanente do trabalho, que foi normatizada pelo Decreto no 10.213, de 22 de agosto de 1990. Por esse Decreto foi criada a Comissão Permanente de Negociaçáo (CPN), bem como foram estabelecidas as regras e procedimentos suficientes para garantir o caráter legal e a formalização da matéria produzida no processo de negociação.

No entanto, a ruptura política ocorrida entre o Governo Municipal e o Partido provocou sérios danos ao processo de negociação e, apesar da manutenção da CPN, pouco se conseguiu realizar em termos de resultados. O próprio processo de negociação não avançou.

Em conseqüência, as relações de trabalho, de modo geral, caminharam para um acirramento dos conflitos naturais do funcionalismo com a Administraçáo, incluindo-se aí alguns períodos de greve prolongada, especialmente no ano de 1992. As relaçōes da Administração e do Governo com o Sindicato dos Servidores Municipais também pioraram muito e o confronto passa a ser a lógica do relacionamento.

Dentro desse cenário, questóes importantes deixaram de ser discutidas. Na área da Saúde, onde a principal característica é a prestação direta de serviço ao usuário, a situação tornou-se crítica. Especialmente nesta área que congrega cerca de 3.000 funcionários em 50 unidades distribuídas pela cidade, havia uma reivindicação antiga, mas consensual, entre os servidores de que a jornada de trabalho mais racional, e de melhor resultado para os usuários e funcionários, era a de sete horas contínuas, e não a de oito horas em dois turnos de quatro. Havia, também, uma certa predisposição e reação por parte das secretarias relacionadas à administração de pessoal, em relação à Secretaria Municipal de Saúde e às suas jornadas de trabalho, muito diversas daquelas mais tradicionais para uma Prefeitura.

Deve-se chamar a atenção ainda para a novidade que representou para as prefeituras a implantação de grandes redes de senviços de saúde e a incorporação de antigas estruturas e funcionários das redes públicas estadual e federal.

A cultura burocrático-administrativa da Prefeitura está em fase de adaptação com as demandas geradas pela SMS, em decorrência dos avanços na implantação do SUS, o que provoca dificuldades de compreensáo e atritos inevitáveis dentro da máquina administrativa.

Na ausência de um canal de negociação efetiva, cerca de trezentos funcionários da rede municipal de Saúde organizaram-se num movimento e passaram a cumprir jornada de trinta horas semanais, em turnos contínuos de seis horas diárias, a partir de outubro de 1992. Esse fato desencadeou a necessidade de encontrar-se rapidamente uma solução para o problema instalado, não só pela desorganização que provocou nas instituições como pelas conseqüências trabalhistas a que ficaram expostos esses funcionários.

Só havia dois caminhos para enfrentar a situação: o tradicional, jurídico-burocrático, ou iniciar um processo de negociação que equacionasse por consenso o problema, sem provocar danos aos usuários do serviço público de saúde. 
$\mathrm{Na}$ opção pela negociação dentro das regras do processo formal instaurou-se um Grupo de Trabalho (Mesa de Negociação), onde não só se debateu a questão principal do problema, mas, e o que talvez tenha sido o resultado mais importante, inaugurou-se uma nova forma de relação dentro das instâncias do Poder Jurídico-Administrativo e de Governo com o Sindicato e os Servidores Municipais. Os ganhos com o processo foram simplesmente fantásticos. Após uma convivência conflituosa, desgastante e desorganizada de quatro anos, todos os envolvidos perceberam na prática a existência de uma metodologia eficiente, capaz de demover preconceitos, não prejudicar usuários e obter resultados legítimos para as partes envolvidas.

O Conselho Municipal de Saúde (CMS), órgão legalmente constituído para representar os usuários e deliberar sobre a organização e funcionamento do SUS no Município, acompanhou o desenrolar das negociações. No entanto, não houve tempo para um aprofundamento dessa participação no processo, o que certamente teria não só enriquecido os debates, bem como poderia ter acrescentado ao produto da matéria negociada a indispensável validação dos usuários, legitimando, através do controle social direto, o avanço que representa a busca do consenso entre as partes envolvidas para a solução dos conflitos decorrentes do processo de trabalho no setor público.

\section{Processo de Negociação}

A negociação foi formalmente instalada pela Portaria do Prefeito de no 27.799, em 20 de outubro de 1992. Por essa Portaria foi criado um Grupo de Trabalho (Mesa de Negociação) com o objetivo de apresentar à CPN, conforme o Decreto no 10.213, de 22 de agosto de 1990, um relatório-síntese da matéria negociada, com justificativas e compromissos estabelecidos, bem como um anteprojeto do instrumento normativo desejado para equacionar o conflito.

A composiçăo deste grupo obedeceu à seguinte determinação: três representantes da Prefeitura, sendo um da Secretaria de Administraçăo, um da Secretaria dos Negócios Jurídicos e um da Secretaria de Saúde; dois representantes da Comissão de Servidores, eleitos em Assembléias; dois representantes do Sindicato dos Servidores Públicos Municipais.

Na prática, os representantes nomeados mantiveram estreita relação com suas bases de representação e toda matéria negociada foi, passo a passo, debatida concomitantemente na Mesa de Negociação e em paralelo no movimento dos servidores, no Sindicato dos Funcionários, na Prefeitura, no Conselho de Governo e no Colegiado de Coordenadores da Secretaria Municipal de Saúde.

É importante destacar que a riqueza do processo de negociação fez com que alguns dos membros da própria CPN passassem a freqüentar a Mesa de Negociação, tendo sido muito importante a participação do Secretário da Administração e do Secretário da Saúde, que abreviaram, com suas presenças, o processo de tomada de decisōes, uma vez que detinham, legalmente, poderes para isso, em nome do Governo. 
A coordenação da Mesa foi decidida pelo próprio grupo, cabendo ao Diretor de Saúde essa tarefa. A secretaria e arquivamento das atas couberam ao Sindicato dos Servidores Públicos Municipais, com a Secretaria da Administração. A redação do anteprojeto a ser enviado à $\mathrm{CPN}$, e posteriormente ao Prefeito, ficou por conta do representante da Secretaria dos Negócios Jurídicos.

O relatório final do grupo, que tem o caráter de um acordo coletivo sobre uma questão específica, estabelecendo justificativas, compromissos, a proposta de regulamentação da jornada, foi redigido coletivamente pelo grupo, levando a chancela final do Secretário da Administração, do Secretário da Saúde, do Presidente do Hospital Municipal, do presidente do Sindicato dos Servidores, dos assessores jurídicos do Sindicato e da Prefeitura e dos participantes nomeados pela Portaria que o criou.

O relatório, acompanhado pelo anteprojeto de lei de flexibilização da jornada de trabalho dos servidores da Prefeitura Municipal de Campinas, foi aprovado pela $\mathrm{CPN}$ e apresentado ao Prefeito que, concordando com seus termos, remeteu-o à Câmara de Vereadores. Nessa fase, foi importante o papel do movimento dos servidores, cujos membros procuraram individualmente os vereadores e suas assessorias, bem como as comissões formais da Câmara, num trabalho de esclarecimentos e demonstração da preocupação e respeito pelos órgãos decisórios do poder público.

Diante desse quadro, a Câmara analisou e aprovou a Lei Municipal no 7.363, que flexibilizou a duração da jornada de trabalho dos servidores municipais, regularizou as jornadas realizadas em sistema de plantão, atribuiu e assegurou a participação da CPN na solução dos conflitos individuais e coletivos decorrentes da aplicação da lei, bem como da sua alteração ou regulamentação. O Prefeito sancionou a lei em 7 de dezembro de 1992 (apresentada a seguir).

\section{Conclusões}

Um conflito com duração de anos, causando desmotivação e angústia para os servidores.

Uma necessidade administrativa de ampliar o horário de atendimento dos Centros de Saúde, impedida de ocorrer pelos custos que representava, caso fossem mantidas jornadas de oito horas, em turno de quatro, com intervalo de duas horas.

Uma burocracia incapaz de encontrar uma soluçăo para o problema.

Usuários deixando de ser beneficiados com a expansão do horário de atendimento dos Centros de Saúde.

Estas quatro constataçōes, acrescidas dos termos do acordo coletivamente firmado, são suficientes para nos convencer de que o processo de negociação de caráter permanente, formalmente implantado, regido, coordenado e arbitrado pelas próprias partes envolvidas, respeitador dos princípios constitucionais e sob a égide do controle social é um importante instrumento, não só de mediação de conflitos decorrentes das relações de trabalho, mas fundamental para a consolidação de políticas públicas efetivamente comprometidas com os interesses da população. 


\section{Decreto e Lei Municipal em Campinas}

\section{Decreto $n^{\circ} 10.213$, de 22 de agosto de 1990}

Dispōe sobre a Comissão Permanente de Negociações (CPN)

O Prefeito Municipal de Campinas, no uso de suas atribuições legais, e, considerando a necessidade de manter órgão paritário mediador de negociações permanentes que envolvam as relaçōes e os conflitos individuais e coletivos de trabalho, no âmbito da Administração Municipal;

considerando a necessidade de regulamentação e implantação do Regime Jurídico Único artigo 9 das Disposiçōes Transitórias da LOM, bem como do desencadeamento de projetos prioritários na área administrativa, tais como a reforma administrativa na Prefeitura Municipal de Campinas, o Plano de Carreira Funcional, o Plano de Cargos/Empregos, o Estatuto do Servidor e o Sistema Previdenciário dos Servidores,

Decreta:

Art. 1․ Fica criada a Comissão Permanente de Negociação (CAN), com o objetivo de solucionar conflitos individuais ou coletivos, surgidos na prestação de serviços e relações de trabalho. A CPN participará, ainda, das discussões dos estudos sobre regulamentação do Regime Jurídico Único - Estatutário, Reforma Administrativa, Plano de Carreira Funcional, Plano de Cargos/Empregos, Estatuto do Servidor e Sistema Previdenciário dos Servidores.

$\S 1^{9}$. Para o cumprimento de seu mister, a Comissão poderá propor a criação de Grupos de Trabalho, determinando-lhes etapas e prazos para a conclusão dos trabalhos que thes forem cometidos.

$\S 2^{\circ}$. Os Grupos de Trabalho serão instituídos por Portarias do Sr. Prefeito Municipal, e seus elementos serão indicados pelos titulares das Secretarias envolvidas com a matéria, no máximo um elemento por assunto e mais um representante do Sindicato.

$\$ 3^{\circ}$. Cabe à Comissão Permanente de Negociação a supenisão das atividades dos Grupos de Trabalho, que deverão apresentar suas propostas em forma de anteprojeto do ato administrativo cabível para a espécie, sendo passíveis de convocação para prestar esclarecimentos.

$\$ 4^{\circ}$. Observar-se-ão os princípios da autonomia e da independência das partes, da transparência administrativa, prioridades às soluçōes negociadas e da autonomia $\mathbf{e}$ liberdade sindical.

Art. $2^{\circ}$. A Comissão Permanente de Negociação (CPN) será integrada por:

1 - 3 (três) representantes da Prefeitura Municipal;

If - 3 (três) representantes do Sindicato (sendo que estes deverão ser servidores sindicalizados);

III - 6 (seis) suplentes, sendo 3 (três) para cada uma das partes. 
§ 1ํ. A coordenação da Comissão será exercida pelo Sr. Secretário de Administração, na qualidade de membro nato dentre os representantes da Prefeitura, ou pessoa por ele designada.

a) os membros da CPN serão nomeados através de Portaria do Sr. Prefeito Municipal.

\section{Lei $\mathrm{N}^{\circ} \mathbf{7 . 3 6 3}$, de 7 de dezembro de 1992}

Dispōe sobre a reduçāo da jornada de trabalho dos servidores municipais e dá outras providências

A Câmara Municipal aprovou e eu, Prefeito do Município de Campinas, sanciono e promulgo a seguinte lei:

Art. 19. A jornada de trabalho dos servidores públicos municipais, com fundamento no disposto no parágrafo 15 do artigo 134 da Lei Orgânica, poderá ser reduzida, observadas as normas estabelecidas nesta lei.

Art. 2ㅇ. Nenhuma jornada de trabalho poderá ser inferior a seis horas diárias e trinta horas semanais, salvo aquelas legalmente previstas com outros limites.

Parágrafo Único. Não será permitida a redução de jornada para os servidores, em exercício de cargo em comissão ou de função gratificada.

Art. 3‥ A redução de jornada de trabalho deverá ser requerida pelo servidor interessado e poderá ser autorizada pelo Prefeito ou por autoridade com competência delegada, desde que:

I - não implique aumento do quadro de pessoal, salvo se ocorrer criação, ampliação ou aumento de serviço público devidamente comprovado;

Il - a redução de jornada não implique a realização de horas extras ou a contratação de pessoal temporário, ressalvadas as exceçōes legais;

III - não contrarie o interesse público e assegure atendimento integral e com qualidade à população, notadamente quanto às obras e aos serviços prestados pelas áreas-fins; base do servidor.

IV - ocorrer a reduçáo proporcional do vencimento padrão ou salário-

Art. 4º. O integrante da Família Ocupacional Universitária, lotado nas áreas da saúde, Hospitais Municipais e Secretaria de Saúde, poderá, observados os requisitos estabelecidos no artigo anterior, requerer a reduçăo de jornada para vinte ou trinta horas semanais, ou para plantões de 12 ou 24 horas, com jornada semanal de 12 ou 24 horas.

Parágrafo Único. O trabalho em regime de plantão a que se refere este artigo fica vinculado às unidades de saúde prestadoras de serviços ininterruptos.

Art. $5^{\circ}$. Fica estabelecido o interstício mínimo de $1(\mathrm{um})$ ano na jornada reduzida para o servidor solicitar nova alteração e de 5 (cinco) anos para fins de aplicação do disposto no artigo 20 e parágrafos da Lei Municipal № 6.767, de 20 de novembro de 1991, na hipótese de ocorrer aumento da jornada de trabalho. 
Art. $6^{\circ}$. Fica assegurada a participação da Comissão Permanente de Negociação na solução dos conflitos individuais e coletivos decorrentes desta lei, bem como na sua alteração ou regulamentação.

Art. $7^{\circ}$. Esta lei entra em vigor na data de sua publicação, revogadas as disposiçōes em contrário.

\subsection{ASSUNTOS RELACIONADOS À PREVIDÊNCIA SOCIAL ${ }^{8}$}

\section{Convênio do Sistema de Gestão Participativa do INSS/SP: experiência premiada pela Escola Nacional de Administração Pública (ENAP)}

Em novembro de 1993 iniciaram-se as discussões entre o Instituto Nacional do Seguro Social (INSS/SP) e a entidade sindical dos Fiscais de Contribuiçōes Previdenciárias (FCPs) do Estado de São Paulo, em torno dos assuntos: participação, qualidade e produtividade dos serviços prestados pelo órgão.

Após amplo processo de debates que contou, inclusive, com a deliberaçăo estatutária da categoria e o apoio oficial da Superintendência do Instituto, em setembro de 1994 foi celebrado o Convênio do Sistema de Gestão Participativa entre a Coordenação de Arrecadação e Fiscalização (CAF) e o Sindicato dos Fiscais de Contribuições Previdenciárias de São Paulo (SINDIFISP/SP).

O tema Previdência Social vem ocupando a pauta de prioridades das instituições políticas do País e da sociedade como um todo desde 1995. Os anseios por mudanças e aprimoramentos no sistema previdenciário brasileiro são tão evidentes quanto polêmicos. Há, sem dúvida, grande conflito de interesses nesta questãoe, certamente, boa parte desses interesses não visa atender às verdadeiras necessidades da população. Contudo, em que pese a existência da polêmica é certo que continuará existindo uma previdência social pública. Continuam, portanto, atuais as preocupaçōes relativas à sua eficiência gerencial. Esta eficiência, no caso do órgão que cuida da arrecadação e fiscalização previdenciárias, poderia ser traduzida no crescimento da receita, no combate eficaz à fraude, à sonegaçăo e à evasão fiscal, e na melhoria da qualidade do atendimento ao público.

Diante destas exigências, os aperfeiçoamentos e a adoção de novas concepções de administração de conflitos e de harmonização das relações de trabalho, como forma de contribuição à eficácia, à produtividade e à qualidade na prestação dos serviços, mantêm-se entre as preocupações permanentes e prioritárias dos diversos atores presentes neste processo. Conseqüentemente, temas como "gestão

8 Experiência premiada no I Concurso Nacional de Experiências Inovadoras de Gestão na Administração Pública Federal, promovido pela Escola Nacional de Administração Pública (ENAP) e pelo Ministério da Administração e Reforma do Estado (MARE), ern 28/10/1996, e vencedora do Prêmio ANASPS de criatividade do Estado de São Paulo, conferido pela Associaçăo Nacional dos Servidores da Previdência Social, em 9/9/1996. 
participativa e qualidade" continuam na ordem do dia, demandando a necessária avaliação do Convênio celebrado com esta finalidade entre a CAF e o SINDIFISP/SP. ${ }^{9}$

\section{Avaliação Objetiva}

Uma avaliação objetiva do desempenho do Convênio do Sistema de Gestão Participativa pode partir das seguintes indagações:

$O$ modelo adotado teve capacidade para responder, satisfatoriamente, às questões que the foram apresentadas?

O Convênio do SGP foi firmado em 27 de setembro de 1994. A última Reunião Ordinária dos participantes para tratar de pauta geral ocorreu em 30 de novembro de 1994. A partir desta data, as atençōes se concentraram, basicamente, na formulação e aplicação da Avaliação Integrada, um sistema aberto e participativo de avaliação de chefias e de servidores. Incluindo a experiência da Avalıação Integrada, o Convênio alcançou um período de dez meses de atividade. Neste curto espaço de tempo foram trazidas à apreciação da Mesa 14 questões. Destas, 11 obtiveram tratamento consensual.

O tempo despendido para as deliberaçóes da Mesa foi, em média, de 12 a 13 dias. O tempo gasto para o encaminhamento das decisóes variou entre a efetivação imediata da decisão e o período máximo de 48 dias. Algumas questões careceram de maior empenho, de tratamento adequado das partes e de providências complementares para serem efetivadas. Mesmo assim, diante dos resultados obtidos, pode-se afirmar que o modelo adotado respondeu satisfatoriamente às questões que lhe foram apresentadas.

Comparando-os aos resultados apresentados, os objetivos gerais e específicos estabelecidos pelo Convênio/SGP estão sendo atingidos?

O Convênio é um conjunto de regras voltadas ao tratamento de conflitos. Regula, às claras, a forma de relacionamento entre Sindicato e Administração. Seus objetivos, após amplo processo de discussão, foram estabelecidos em decorrência da necessidade de se adotar estratégia de construção de aliança política e de interesses com a sociedade. Aliança esta calcada no compromisso comum de oferecer qualidade aos serviços previdenciários demandados pela cidadania, como forma eficaz de se defender a Previdência Social e Pública.

Alguns tópicos tratados pela Mesa de Participação Permanente revelam o alcance e o atendimento a esses objetivos, a saber:

\section{Planejamento da Ação Fiscal}

A Mesa de Participação Permanente aprovou o princípio geral pelo qual os fiscais e o Sindicato devem ter acesso e participação mais efetiva na elaboração do Planejamento da Ação Fiscal. Participaçôes deste tipo geram compromissos entre os

9 Convênio reproduzido na íntegra no capítulo 2, seção 2.5 . 
partícipes e estimulam o cumprimento de metas. Explicitam as prioridades administrativas e as dificuldades inerentes à sua execução. Esta prática proporciona acompanhamento e controle por parte de um grupo maior de pessoas, conferindo credibilidade ao sistema e confiabilidade aos servidores envolvidos. Contribui para reduzir os conflitos decorrentes, muitas vezes, da deficiência de informações ou do desconhecimento dos critérios adotados pelo Administrador.

No mais, esta participação é de fundamental importância para permitir uma nova abordagem da Produtividade Fiscal. Contudo, faltou dar maior efetividade ao que foi aprovado, especialmente por parte da Administração, uma vez que o assunto não voltou mais à pauta de reuniōes. A adoção deste modelo de Planejamento com Participação atende aos interesses da sociedade, pois combina a busca por maior eficácia e produtividade com a busca por maior controle e democracia, resultados que vão ao encontro dos objetivos definidos no Convênio.

\section{Grupo de Estudo de Previdência Pública}

O Grupo de Estudo de Previdência foi constituído por representantes do SINDIFISP/SP, da APAFISP e da CAF, todos fiscais qualificados, profissional e intelectualmente, para produzirem estudos, análises críticas e propostas sobre o sistema previdenciário brasileiro. Durante meses, com seus integrantes liberados do trabalho de fiscalização, o Grupo trabalhou sistematicamente. Ao final, produziu excelente material de pesquisa e de suporte às discussóes que se realizam sobre a reforma previdenciária.

Editado na forma de livro pelo SINDIFISP/SP, o trabalho constitui material obrigatório para especialistas e estudiosos do assunto. Colocar à disposição da sociedade estudo científico e tecnicamente qualificado sobre o sistema previdenciário e as diversas propostas de mudanças que estão em curso, certamente, constitui uma importante contribuição ao debate democrático das idéias e aos anseios da cidadania por uma previdência social mais eficiente. $O$ trabalho desenvolvido pelo Grupo de Estudo de Previdência evidencia, uma vez mais, o atendimento aos objetivos conveniados.

\section{Plantão Fiscal}

Este item foi tratado a partir de diagnóstico que revelava a ausência de uma padronização básica para o Plantăo Fiscal de Atendimento ao Contribuinte. A entidade sindical realizou enquête junto aos FCPs, e a Administração colheu informações junto aos Gerentes das GRAF's. A partir deste trabalho, foram detectadas falhas e possibilidades de melhoria da qualidade do atendimento ao público. As sugestões colhidas foram transformadas em normas administrativas.

Aprovou-se, também, o procedimento da Avaliaçáo Semestral, a ser realizada junto aos usuários, acerca do atendimento prestado em cada GRAF. Ficou de ser elaborado, conjuntamente, o Manual do Plantonista que ficará à disposição, nos locais de Plantão, também dos usuários. Estes poderão cobrar o atendimento recomendado no documento. 
Ao padronizar procedimentos e orientar condutas, estabelece-se, através de processo educativo, nova e saudável rotina administrativa de qualificação dos serviços prestados ao público e de harmonização do ambiente de trabalho. Trata-se de mais um tópico que efetiva os objetivos almejados no Convênio.

\section{Avaliação de Desempenho das GRAFs}

As concepções mais avançadas de administração, pública ou privada, trazem a recomendação expressa das avaliações de desempenho como elementos essenciais à implementação de programas de qualidade.

A Avaliação Integrada, introduzida em fins do ano de 1994, permite submeter o trabalho de cada um à sua própria avaliação e à avaliação da Administração e dos demais servidores, inclusive dos subordinados. Conseqüentemente, os trabalhos dos Gerentes são avaliados pelos FCPs de pasta e vice-versa. A GRAF, como um todo, faz a sua auto-avaliação.

Ao que se sabe, foi a primeira vez que uma avaliação deste nível foi aplicada na área previdenciária. A Avaliação Integrada constitui, pois, ferramenta indispensável para introduzir uma nova cultura de serviços qualificados. Este processo ratifica, mais uma vez, a consecução dos objetivos de eficácia, qualidade, produtividade e democracia, perseguidos de comum acordo pelo Convênio.

\section{Outros Modelos Conhecidos}

A introdução do Sistema de Gestão Participativa, por ser novidade, gera dúvidas, controvérsias e expectativas, inclusive entre os partícipes do Convênio. Esta constatação, a eleição da nova diretoria do sindicato e as mudanças na cúpula administrativa abriram novas oportunidades para reflexões. Afinal, que linha de ação e que modelo de relacionamento Administração-Sindicato são mais adequados aos interesses envolvidos?

É importante lembrar que, resumidamente, o Convênio/SGP tem por objetivo central "dar tratamento e soluçöes aos conflitos que insurgem no processo de trabalho e que afetam, direta ou indiretamente, a qualidade, a eficácia e a produtividade dos serviços" (Cláusula 4⿳亠丷冖).

A Gestão Participativa constitui-se, portanto, instrumento de regulação das relações Administração-Sindicato. O Convênio é um documento que contém regras sobre a forma de relacionamento adotada por ambos. Tem por substrato promover o envolvimento, a integraçăo e a participação do conjunto dos fiscais, nos assuntos de interesse da instituição e da corporação. Seu objetivo primordial, contudo, é coadunar e combinar interesses comuns, direcionando a solução dos conflitos para a busca da melhoria da qualidade dos senviços previdenciários prestados pela fiscalização.

Diante de indagaçōes deste tipo, conhecer outros modelos e compará-los com a opção adotada torna-se imprescindivel para quem deseja formar um juízo de valor equilibrado. 
Face às preocupações mencionadas, para fins comparativos e exemplificativos, convém analisar as três concepções mais discutidas e conhecidas de tratamento de conflitos e de forma de relacionamento Administração-Sindicato, a saber:

- o burocratismo e a linha de confronto sindical;

- o clientelismo e o favoritismo administrativos;

- a co-gestão administrativa.

\section{O Burocratismo e a Linha de Confronto}

A característica desta forma de administrar conflitos é a concentração excessiva e muitas vezes despótica de poder e o seu exercício de maneira arrogante e intimidatória. Este modelo afasta qualquer tipo de participação e acredita na imposição de ordens como único meio de solução de conflitos, ainda que estes reapareçam na forma de confronto ou de ineficiência administrativa.

As características das relações Administração/Sindicato, nestes casos, são de confronto ou meramente burocráticas. Ou seja, ou a entidade sindical arregimenta forças e assume o confronto, ou sua atividade se resumirá, praticamente, a encaminhar eventuais medidas judiciais e a publicar, em seus boletins, ofícios e notas de protestos. Distorções na linha de ação sindical também podem contribuir para a adoção desta concepçăo autoritária de administração de conflitos.

\section{O Clientelismo e o Favoritismo Administrativos}

Trata-se da velha fórmula sustentada na troca de favores, na negociata de cargos e no apadrinhamento político. Administração e entidades de classe passam a ser dirigidas praticamente pelas mesmas pessoas. São perseguidos interesses pessoais, e não os interesses-fim da instituição pública, ou os legítimos interesses da entidade sindical. É o sistema que mais se aproxima da cooptação de um pelo outro.

Os conflitos de interesses são discutidos e negociados sem regras claras e sem mecanismos de controle, tudo com sabor de concessão pessoal e despótica. Há forte injunção política externa neste sistema e pouco espaço para a adoção de critérios administrativos, técnicos e transparentes. Os interesses da instituição e da sociedade podem até ser preservados, desde que não afetem os interesses pessoais dos participantes.

\section{A Co-gestão Administrativa}

São pouquíssimas as experiências conhecidas de co-gestões administrativas, adaptadas às limitações legais e às características do setor público. De caráter eminentemente político, sua fórmula exige, necessariamente, a co-participação no exercício das funçōes incumbidas da execução do programa. Ou seja, implica a divisão e a ocupação de cargos administrativos. Se conduzido de forma implícita ou velada, este sistema se confunde bastante com modelos de corte clientelista.

Há, neste sistema, por um lado, delegação, transferência ou divisão de responsabilidades administrativas e, por outro, perda relativa da autonomia sindical. Sua adoção poderá acarretar, portanto, distorções de finalidades, pois, não raro, a atividade 
administrativa exige providências que nem sempre são de interesse corporativo. E não necessariamente as demandas sindicais estarão sempre voltadas à consecução de interesses específicos da administração pública.

Ao administrador compete, legal, obrigatória e exclusivamente, praticar todos os atos necessários à consecução das finalidades administrativas, ainda que firam interesses corporativos. Já os sindicatos não podem agir contra interesses corporativos, pois a defesa desses interesses constitui a sua essência.

\section{Comparação com a Gestão Participativa}

A gestão participativa não transfere atribuições do administrador público, nem impōe limitações à autonomia sindical, distanciando-se, desta forma, substancialmente do modelo de co-gestăo. As responsabilidades pela consecução das finalidades administrativas continuam de exclusiva competência do administrador. A defesa dos interesses corporativos é feita de forma incondicional pela entidade. A participação da entidade sindical é pontual e não genérica. É conduzida a partir de proposições expressas e fundamentadas.

O que acontece neste modelo é, em primeiro lugar, a percepção da existência de um vasto campo de interesses comuns que podem ser coadunados. Uma vez estabelecidos como interesses comuns reconhece-se que ambas as partes detêm legitimidade para deles tratar.

A busca da qualidade, por exemplo, deve ser bandeira de todos e não de parte dos envolvidos. Surge daí a natureza participativo-propositiva que tanto caracteriza este modelo. Esse caráter participativo-propositivo confere maior credibilidade e autoridade às ações administrativas e maior legitimidade e espaço de ação para atividades sindicais.

Para tratar de assuntos específicos de interesse comum é preciso discutir propostas pontuais e concretas, cuja viabilidade contribua também para a consecução das finalidades gerais da Administração. É neste reforço da credibilidade e da viabilização das finalidades administrativas que repousa o interesse maior do administrador em adotar este modelo. E é na ampliação do espaço para o exercício da atividade sindical e no acréscimo da legitimidade decorrentes do exercício da função propositiva que a entidade sindical vê vantagens substanciais em sua adoção.

De resto, o modelo evita a concentração excessiva de poderes, o despotismo, os privilégios, os apadrinhamentos, as omissões ou a transferências de responsabilidades (características dos demais modelos analisados). Evita, também, a prática de um sindicalismo inconseqüente, burocrático, de adesão ou de confronto, características que não condizem com o perfil da categoria representada. A gestão participativa é um conjunto de regras e de critérios de solução de conflitos, fixados transparentemente, de comum acordo, para a defesa de interesses específicos. 


\section{Conclusões}

Comparadas à magnitude dos problemas que atingem a previdência pública $\mathbf{e}$ a sua categoria funcional, questōes como as tratadas pela Mesa de Participação Permanente podem parecer menores. Contudo, é necessário, nesta avaliação, considerar o pouco tempo de funcionamento do novo sistema, os limites de sua abrangência e uma certa timidez das partes em apresentar e negociar tópicos. Ainda assim, é preciso notar que os assuntos tratados pelo Convênio foram e continuam sendo da mais alta importância para o bom funcionamento do serviço.

Não temos notícias da adoção de procedimentos semelhantes em nosso meio. Procedimentos como a avaliação dos gerentes por seus subordinados. Ou o trabalho crítico realizado pelo Grupo de Previdência. Ou a reformulação do atendimento ao público, a partir de sugestóes colhidas pelo sindicato junto aos fiscais. Alguém conheceu alguma outra experiência concreta de participação crítica e propositiva, organizada e construtiva, de defesa de interesses da categoria aliada à defesa de interesses gerais da sociedade?

Entretanto, é certo que o sistema não pode ser apresentado como panacéia para todos os males. Para uma etapa considerada de implantação os resultados são satisfatórios. Quando se compara o Convênio com outras formas de lidar com assuntos semelhantes, pode-se dizer que os resultados são excelentes. Especialmente se a comparaçăo for feita em relação ao período que antecedeu a introdução deste modelo, quando os assuntos entre Sindicato e Administração eram tratados na base da troca de ofícios ou exclusivamente através da publicação de críticas e de protestos nos boletins da entidade.

Consideramos que o funcionamento do SGP nas GRAFs - uma insistência constante do Coordenador da Mesa - seria, como continua sendo, vital para a eficácia do projeto. Sua implementação efetivaria um canal imediato e direto de expressão de conflitos localizados. São conflitos que, somados, acabam por interferir na produtividade e na qualidade dos serviços.

Por outro lado, a introdução desse mecanismo de participação articulada e descentralizada contribuiria para viabilizar a 'organização nos locais de trabalho', um dos princípios sagrados da linha sindical combativa. Ressalte-se, ainda, que o convênio assegura eleições livres e diretas de representantes nos locais de trabal ho para participar da Mesa. Mesmo assim náo houve empenho ou receptividade por parte da entidade sindical para implantação dessa etapa do projeto.

Importa saber, contudo, se vale a pena ou não manter o Convênio já firmado, se é o caso de aprimorá-lo como condição para mantê-lo, se há algum novo modelo de relacionamento a ser analisado, ou se a opção é o retorno aos modelos já aplicados no passado.

A necessidade de abertura e de aprofundamento político da discussão deste assunto, junto aos senvidores, é fundamental. Estes devem escolher se a relação Sindicato-Administração deve ser pautada pela atuação combativa e crítica, mas também propositiva das suas entidades sindicais, pela linha de confronto exclusivo, por uma relação baseada na troca de favores, ou pela co-gestão, baseada na ocupação de cargos, para ficar nos modelos comentados. E saber que para cada modelo há um 
custo a ser arcado por eles próprios. Por exemplo: linha exclusiva de confronto, para obter resultados, exige grande capacidade de mobilizaçăo e de pressão, com muita disposição para a greve. No extremo oposto está a co-gestão administrativa que implica, praticamente, despojar o sindicato do seu papel crítico e combativo.

A existência do Convênio não garante, por si só, a obtenção de resultados. Estes dependem da capacidade das partes em conquistá-los na negociaçáo, usando como pressão todos os instrumentos legais disponíveis (inclusive a greve, no caso do Sindicato). O Convênio estabelece apenas a forma, as regras da negociação. Até mesmo nas grandes guerras em que a humanidade se envolve há regras de negociação, decorrentes da existência de interesses comuns, como ocorre com as regras de respeito à vida, à integridade física e à troca de prisioneiros entre os beligerantes. Caso as regras não estejam atendendo aos objetivos estabelecidos devem ser aprimoradas ou substituídas e não simplesmente extintas, pois a sua inexistência não contribuirá para galgar legítima, ética e objetivamente os resultados almejados.

A decisão sobre a linha de relacionamento e o compromisso de respaldar a ação da entidade sindical constituem responsabilidades de cada servidor. O sindicato, sem esse comprometimento, pouco poderá realizar. A Ad́ministração, sem a colaboração esforçada do seu corpo funcional e o envolvimento dos demais interessados, não será capaz de viabilizar, com qualidade, eficiência e democracia, as demandas da cidadania por uma verdadeira Previdência Social e pública.

\section{A Experiência da Avaliação de Desempenho Produzida pelo Sistema de Gestão Participativa do INSS}

Com a participação direta do sindicato, das chefias e dos subordinados

O Convênio do Sistema de Gestẫo Participativa, celebrado entre a CAF/INSS/SP e o SINDIFISP/SP, foi capaz de produzir um modelo de avaliação de desempenho do serviço no qual todos os Fiscais de Contribuiçōes Previdenciárias puderam participar, em condiçōes de absoluta igualdade.

Gerentes, chefias de um modo geral e subordinados tiveram a oportunidade de auto-avaliarem seu desempenho e de avaliarem o desempenho dos demais colegas.

A proposta foi desenvolvida conjuntamente pelas partes e o processo ocorreu nos prazos e nas condições solicitadas pela entidade sindical. Foi também a entidade sindical que encaminhou o material para as mais de trinta Gerências Regionais do Estado, fiscalizou a aplicação dos questionários e procedeu à tabulação das suas respostas.

É de se ressaltar, nesta experiência, o fato de a categoria representada (Fiscais da Previdência) ter avaliado de forma bastante positiva a gestão administrativa coordenada pela colega Ayda Tereza Sonnesen Losso, não por acaso co-responsável direta pela introdução do novo modelo de gestão participativa na instituição.

Com efeito, do total de quesitos respondidos pelos servidores, $72,82 \%$ das respostas obtidas consideraram positivo o desempenho geral da instituição, contra $24,44 \%$ de avaliação negativa desse mesmo desempenho. 
Lamenta-se, apenas, que este procedimento democrático e participativo de avaliação de desempenho, que poderia ser aperfeiçoado e aplicado sistematicamente, inclusive para balizar discussōes da Mesa de Participação Permanente nos locais de trabalho, tenha sido abandonada pelas partes. A entidade sindical não mais reivindicou sua aplicação, como, de resto, não reivindica a aplicação e o funcionamento do Sistema de Gestâo Participativa.

Para que a experiência possa ser compreendida pelos interessados, apresentamos, a seguir, o relatório sintético e consensual dos trabalhos de avaliação, de nossa autoria, acompanhado de tabela contendo os resultados finais (Anexo 1) e de cópia do questionário aplicado (Anexo 2).

\section{Avaliação Integrada das GRAFs: Relatório dos trabalhos ${ }^{10}$}

Até o presente momento foram desenvolvidas três etapas dos trabalhos de Avaliação Integrada, conduzidos por intermédio da Mesa de Participação Permanente, instalada nos termos do Convênio do Sistema de Gestão Participativa, celebrado entre a CAF/SP e o SINDIFISP/SP, da seguinte forma:

1aㅡ etapa: definição de objetivos e da proposta

Em 3/11/94, a Mesa de Participação Permanente aprovou a proposta de Avaliação Integrada das GRAFs , em razâo da reivindicação de Avaliação interna sobre o desempenho das gerências regionais, apresentada pelo SINDIFISP/SP, em 17/10/94. Diz o texto da proposta aprovada:

Com o objetivo de melhorar a qualidade, a produtividade e a eficácia dos serviços, a Administração tem interesse no maior envolvimento e na maior participação dos fiscais e dos servidores administrativos nas avaliaçōes de desempenho das GRAFs.

A CAF sugere, para tanto, a aplicação de um método de Avaliação Integrada, apoiada em diagnóstico, a ser elaborado através de quesitos, escolhidos de comum acordo, da seguinte forma :

1. O público-alvo seria distribuído em três grupos, a saber :

a - Grupo de Servidores Administrativos ;

b - Grupo de FCPs em trabalho de rua;

c - Grupo de FCPs em trabalho interno.

II. Os quesitos seriam divididos em duas categorias :

a - voltados para a auto-avaliação do próprio grupo;

b - voltados para a avaliação dos demais grupos.

III. Quanto ao seu caráter, os quesitos atenderiam a duas ordens de preocupação, a saber:

a - de caráter subjetivo, visando a diagnosticar a qualidade das relaçóes interpessoais, o nível de motivação, a avaliação pessoal da capacitação profissional, as

10 Documento datado de 18/05/95, contendo as seguintes rubricas: Ayda Tereza Sonnesen Losso Coordenadora - CAF - INSS/SP; Carmelina Calabrese Nunes - Presidente - SiNDIFISP/SP, Silvana Garcia Leal - Secretária da Mesa; Douglas Gerson Braga - Coordenador da Mesa. 
expectativas profissionais, os aspectos positivos e negativos do trabalho na GRAF, as dificuldades para o desempenho das funções etc., além de coletar sugestões para o aperfeiçoamento destas relações.

b - de caráter objetivo, visando diagnosticar aspectos da eficácia, da produção e do funcionamento estrutural da GRAF, e colher sugestões de aperfeiçoamento.

2 2 etapa: elaboração e aplicação dos questionários

Foram elaborados, consensualmente, 31 quesitos, aplicados por intermédio de questionários, respondidos de forma livre, sigilosa e anônima pelos fiscais lotados em trabalho 'de pasta' ou em atividades internas das GRAFs.

Este procedimento foi acompanhado por representantes do Sindicato e das Gerências e ocorreu, para a quase totalidade das GRAFs, durante as reuniōes oficialmente convocadas de Avaliação das Gerências, na semana de recesso, em dezembro de 1994. O sistema adotado, como todos sabem, foi o de atribuir-se notas a quesitos.

Os quesitos foram "dispostos em forma polarizada: os da coluna $A$ representam uma relação positiva e os da B representam uma relação negativa", a fim de aferir-se o nível de aprovação ou de rejeição sobre cada um (texto de apresentação dos questionários individuais).

Fundada na premência do tempo e na diferença das funções desempenhadas, as partes decidiram, antes da elaboração dos quesitos, pela aplicação da Avaliação Integrada junto aos Servidores Administrativos em uma etapa posterior.

$3^{\underline{a}}$ etapa: tabulação dos dados

O SINDIFISP/SP ficou incumbido da coleta e da tabulação dos dados extraídos dos questionários, o que foi feito entre o período de janeiro a março do corrente ano, com auxílio de assessoria técnica especialmente contratada pela entidade. Feito isto, produziram-se documentos iniciais, de caráter técnico, agora submetidos à apreciação da Mesa de Participação Permanente.

Abre-se, assim, a discussão dos documentos conclusivos desta terceira etapa dos trabalhos, razão pela qual a Mesa de Participação Permanente apresenta a todos os fiscais os resultados obtidos e anuncia as próximas etapas a serem seguidas.

\section{Os Resultados da Avaliação Integrada}

O material que ora se apresenta registra a avaliação que os fiscais do Estado de Săo Paulo fizeram sobre as questões que lhes foram submetidas. A análise desses dados permite verificar:

a) a avaliação média, quesito a quesito, extraída de todo o contingente fiscal, sobre o desempenho de todas as GRAFs ;

b) a avaliação média das GRAFs, extraída, separadamente, de um grupo constituído por fiscais 'de pasta' e de outro, por fiscais em trabalho interno;

c) a avaliação média dos FCPs, em conjunto ou separadamente em dois grupos, sobre o desempenho da GRAF em que atuam. 


\section{A Continuidade dos Trabalhos de Avaliação}

Em reunião realizada pela Mesa de Participação Permanente em 11/04/95, decidiu-se o seguinte, em termos de continuidade dos trabalhos de Avaliação:

- dar publicidade aos resultados da Avaliação Integrada, apresentando o presente relatório, acompanhado das tabelas e dos gráficos em anexo;

- realizar reunióes nas GRAFs para analisar os resultados da Avaliação quanto ao seu mérito, diagnosticar causas e apontar sugestôes, considerando como roteiro e ordem do dia os resultados da Avaliação, quesito a quesito, de cada GRAF, da seguinte forma :

a) para as reuniōes da Avaliação devem ser convocados todos os FCPs da GRAF;

b) a cada semana será realizada reunião em uma GRAF, a ser escolhida, alternadamente, pelo Sindicato e pela CAF.

\section{Conclusōes}

A Avaliação Integrada é uma conquista da área de Arrecadação e Fiscalização do Estado de São Paulo, em benefício da Instituição. Conduzida de forma objetiva, honesta e transparente, ao institucionalizar-se poderá vir a transformar-se em um dos principais mecanismos de participação para a eficácia do setor. Sua aplicação completa permitirá obter um diagnóstico amplo e preciso sobre as diversas questões que se colocam no curso dos trabalhos da fiscalização.

Afora o caráter de diagnóstico, este método de avaliação envolve e integra pessoas, estimula e organiza a discussão de sugestóes e facilita a correção de rumos e a adoção de medidas de aperfeiçoamento para a área.

Ouvir, conhecer e discutir as dificuldades de cada um, as razões e as diversas maneiras de se tratar um problema, introduzir sugestōes colhidas etc. são procedimentos que, sem sombra de dúvida, devem contribuir de forma substancial para a obtenção da melhoria da qualidade dos serviços.

Não por acaso, esta melhoria da qualidade constitui o principal objetivo do Convênio do Sistema de Gestão Participativa e, ao lado da defesa da Previdência Social e Pública, detém um dos índices mais alto de 'positivo' na opinião dos fiscais, nesta primeira Avaliação Integrada que realizamos.

Para os fiscais, esta melhoria da qualidade há de traduzir-se em melhorias na qualidade das suas relações profissionais e, para a instituição, em última instância, em melhorias nos níveis da arrecadação previdenciária, para que a Previdência Social possa cumprir as finalidades almejadas pela cidadania.

Seguem as tabelas e os gráficos contendo os resultados finais da terceira etapa da Avaliação Integrada. ${ }^{11}$

$11 \mathrm{Em}$ face do seu volume, o material referido não será apresentado na íntegra. Seguem publicadas a Tabela de Resultado Geral do Estado de São Paulo (Anexo 1) e cópia de parte do questionário aplicado na Avaliação (Anexo 2). 


\section{Avaliação Integrada das GRAFs: resultados gerais (Anexo 1)}

Fiscais consultados - trabalho externo: $\mathbf{8 7 0}$

- trabalho interno: 214

TOTAL: 1.084 FISCAIS

\begin{tabular}{|c|c|c|c|c|}
\hline \multicolumn{5}{|c|}{ RESULTADO GERAL DO ESTADO DE SÄO PAULO } \\
\hline \multirow{2}{*}{$\begin{array}{c}\text { QUESITOS } \\
\text { RESUMO DOS ENUNCIADOS }\end{array}$} & \multicolumn{2}{|c|}{ FCP GERAL } & \multicolumn{2}{|c|}{$\%$} \\
\hline & POS. & NEG. & POS. & NEG. \\
\hline 1 - SUPERVISOR: REPASSE DE INFORMAÇŌES & 888 & 173 & 81,92 & 15,96 \\
\hline 2 - SUPERVISOR: ORIENTAÇŌES AOS FISCAIS & 902 & 157 & 83,22 & 14,48 \\
\hline 3 - GERÊNCIA: PARTICIPAÇÃO DOS FCPS & 687 & 380 & 63,38 & 35,06 \\
\hline 4- GERÊNCIA: CRITÉRIO NA APLICAÇÃO DAS LEIS & 977 & 74 & 90,13 & 6,38 \\
\hline 5 - GERÊNCIA: DISTRIBUIÇÃO JUSTA DE TAREFAS & 706 & 356 & 65,13 & 32,85 \\
\hline 6 - GRAF: APROVEITAMENTO DA FREQUÊNCIA DO FCP & 840 & 217 & 77,50 & 20,00 \\
\hline 7 - GERÊNCIA: DETEMINAÇÃO PARA FISCALIZAR & 915 & 144 & 84,40 & 13,30 \\
\hline 8- INFORMÁTICA: CRAU DE EFICIÊNCIA & 230 & 840 & 21,21 & 77,49 \\
\hline 9 - GERÊNCIASSUPERV.: APOIO AOS FCPS & 978 & 85 & 90,22 & 7,84 \\
\hline 10 - CHEFIAS: INTERPRETAÇÃO UNIFORME DA LEI & 842 & 227 & 77,67 & 20,95 \\
\hline 11 - GERÊNCIA: DISTRIBUIÇÃO CRITERIOSA DAS DIÁRIAS & 802 & 153 & 73,99 & 14,11 \\
\hline 12 - FCP: DISPOSIÇĀO PARA O TRABALHO INTERNO & 812 & 248 & 74,90 & 22,88 \\
\hline 13 - PLANEJAMENTO TRIMESTRAL: EFICÁCIA & 589 & 455 & 54,34 & 41,97 \\
\hline 14 - GRAF: QUALIDADE DAS INSTALAÇŌES FíSICAS & 436 & 637 & 40,22 & 58,76 \\
\hline 15 - RH / TREINAMENTOS: OPÇŌES E CRITÉRIOS & 384 & 686 & 35,42 & 63,28 \\
\hline 16 - GERÊNCIASSUPERV.: REUNIÓES DE AVALIAÇĀO & 757 & 310 & 69,83 & 28,60 \\
\hline 17 - GERENTE: MANTER O MORAL DO GRUPO ELEVADO & 736 & 324 & 67,89 & 29,89 \\
\hline 18 - SUPERVISOR: CAPACIDADE TÉCNICA & 867 & 180 & 79,68 & 16,61 \\
\hline 19 - FCPS GERENTES E SUPERV.:COOPERAÇĀO E APOIO & 891 & 170 & 82,19 & 15,68 \\
\hline 20 - FISCALIZAÇÃO E ARREC.: CLIMA DE RESPEITO & 779 & 283 & 71,86 & 26,11 \\
\hline 21 - GERÊNCIA: CRITÉRIOS PARA ESCOLHA DE EQUIPE & 802 & 217 & 73,98 & 20,02 \\
\hline 22 - PREV. PÚBLICA: DEFESA ATRAVÉS DA QUALIDADE & 966 & 85 & 89,11 & 7,84 \\
\hline 23 - PRODUTIVIDADE: AUMENTO DA ARRECADAÇÄO & 862 & 187 & 79,52 & 17,25 \\
\hline 24 - FCP: PRODUTIVIDADE LIMITE MÁXIMO & 872 & 184 & 80,44 & 16,98 \\
\hline 25 - FCPs: PRODUTIVIDADE ACIMA DO MÍNIMO & 910 & 150 & 83,95 & 13,84 \\
\hline 26 - FCP: INTERESSE NAS DISCUSSÕES DE TRABALHO & 977 & 79 & 90,13 & 7,29 \\
\hline 27 - FCP: INTERESSE EM TREINAMENTOS & 991 & 66 & 91,42 & 6,09 \\
\hline 28 - FCPs : INTERESSE EM PARTICIPAR & 814 & 247 & 75,09 & 22,79 \\
\hline 29 - FCPS: SOLIDARIEDADE COLABORAÇĀO & 857 & 205 & 79,06 & 18,91 \\
\hline 30 - FCP: COMPETÊNCIA GERENCIAL (ERRO/REDAÇÃO) & 455 & 592 & 41,98 & 54,61 \\
\hline 31 - FCPS E SUPERIORES: HONESTIDADE & 954 & 104 & 88,00 & 9,60 \\
\hline TOTAIS DE RESPOSTAS & $\mathbf{2 4 . 4 7 8}$ & 8.215 & 72,82 & 24,44 \\
\hline
\end{tabular}




\section{Exemplo do Material Aplicado na Avaliação Integrada (Anexo 2)}

\section{PREVIDÊNCIA PÚBLICA E GESTÃO PARTICIPATIVA}

\section{A}

1- Normaimente, em minha Graf, estamos bem informados - o supervisor repassa as informações disponíveis.

2 - Quando alguém comete erros, o supervisor o chama em particular e o orienta.

3 - É freqüente, na minha Graf, os FCPs serem ouvidos previamente quando de alguma mudança.

4 - No que depender de gerência, a lei é sempre aplicada igualmente, para todos os contribuintes.

5 - As tarefas ingratas são igualmente compartilhadas por todos.

6 - Estando na Graf sermpre posso trocar uma idéia sobre o serviço ou adiantar alguma coisa em andamento.

7 - Quando aponto uma empresa em débito, não tenho dúvidas de que a mesma será fiscalizada.

8 - Os equipamentos e os programas de informática do INSS funcionam bem $e$ atendem às minhas necessidades funcionais.
B

654321 de nada; o supervisor não repassa informações.

2 - Quando alguém comete erros, 654321 ou é o último a saber, ou simplesmente recebe o serviço de volta sem nenhuma orientaçăo.

3 - Na minha Graf ninguém pede 654321 sugestões ou nunca somos ouvidos.

654321

4 - No que depender da gerência, há discriminação e favorecimento de contribuintes, na aplicação da lei.

5- Quando há tarefas espinho654321 sas, sempre os mesmos são 'premiados'.

6- Ficar na Graf é perda de tempo, 654321 pois quase sempre falta o material de que estou precisando e não há a preocupação de passar qualquer informação adicional.

7 - Quando aponto uma empresa 654321 em débito, não posso afirmar que a mesma será fiscalizada.

8 - Os programas de informática 654321 trouxeram mais serviço burocrático para os fiscais, são ineficientes, apresentam muitas falhas na implantação e necessitam ser aperfeiçoados. 


\section{4 \\ A Negociação de Conflitos em Época de Escassez de Recursos}

Teoria e prática se encontram neste último capítulo. Apresenta-se, aqui, estudo detalhado sobre a técnica da negociação de conflitos. Inédito no Brasil, foi encomendado pelas Organizações Mundial e Pan-Americana da Saúde. Técnicas de negociação, posturas de negociadores e procedimentos bem definidos previamente acordados entre as partes compõem este capítulo.

A inclusão desses estudos dispensa justificativas. Sempre haverá conflitos de interesses. Seu tratamento, em muitos casos, não escapará de um processo de negociação, por mais autoritária que seja a visão de quem comanda. Assim, a teorizaçăo e a sistematização de técnicas e métodos que organizem e facilitem a negociação de conflitos, respeitando a diversidade de interesses sempre presentes em situações complexas como os sistemas produtivo e de trabalho - ganham importância fundamental, independente dos modelos sugeridos e estudados nos capítulos anteriores.

Os estudos aqui apresentados podem ser aplicados não só a situações empíricas e informais, mas também a modelos organizados de gestão apoiados em princípios participativos e democráticos. Os conflitos tornam-se, então, estímulo para aumentar a qualidade tanto para os servidores quanto para os usuários dos serviços.

Por este motivo, instituições internacionais prestigiadas patrocinaram a produção desse trabalho, a tradução para o português e a sua inclusão neste capítulo.

\section{A NEGOCIAÇÃO COMO INSTRUMENTO DE GERÊNCIA NO SETOR PÚBLICO}

O texto que se apresenta a seguir é uma adaptação do trabalho "Capacidade de Negociação no Setor Saúde", de Iveta Ganeva e José Maria Marin. Foi publicado em janeiro de 1993, produzido no Projeto Sub-regional de Consolidação e Incremento da Capacidade Gerencial dos Serviços de Saúde para a América Central, Divisão de Sistemas e Serviços de Saúde, patrocinado pela OPS/OMS e PNUD/PEC. Foi traduzido 
e adaptado por Eliana Parise Braga e David Braga Júnior, por autorização da representação da OPS no Brasil. Miguel Segovia fez a revisão técnica.

O documento original foi traduzido, tendo seus termos técnicos preservados sempre que possível, respeitando-se as características dos idiomas. Nem sempre há correspondência exata entre os termos usados em espanhol quando traduzidos para o português. Procurou-se usar sempre a palavra em português com significado mais próximo do termo original. Algumas vezes, no entanto, ou por não existir a palavra correspondente, ou por desuso na nossa cultura, optou-se pelo termo em uso mais corrente na língua portuguesa.

Além destas observaçōes, merecem ser considerados conceitos introduzidos ou complementados em decorrência das peculiaridades da realidade política-jurídica-burocrática brasileira, sem o que a compreensão e o uso dos conceitos utilizados no original estariam prejudicados.

Algumas citações foram revistas, e as fontes originais, consultadas novamente para uma melhor tradução. Trechos de outras obras foram inseridos no texto para melhorar aspectos didáticos da adaptação.

O texto foi adaptado com o objetivo de servir como leitura complementar para o Programa de Desenvolvimento de Recursos Humanos da OpAS no Brasil, na área de Capacitação em Gerência de Unidades Básicas de Saúde do Distrito Sanitário.

A gerência pública em saúde, interpretada como gestão de políticas e condução e execução de processos de produção social da saúde e, mais ainda, como marco específico do desenvolvimento de cada país, impõe novas funções. Conseqüentemente, são necessárias novas capacidades.

Conduzir o processo gerencial, além de requerer o desenvolvimento de habilidades diretivas tradicionais, necessárias para o exercício da autoridade, requer hoje, principalmente, a habilidade de promover o ajuste consensual entre atores sociais independentes e participantes no processo de produção de saúde. Em outras palavras, além de saber mandar nos subalternos dentro da hierarquia institucional, é necessário saber negociar em pé de igualdade com atores fora da estrutura hierárquica institucional, mas com interesse e capacidade potencial de intervir.

Por este motivo, dentro da linha de apoio ao desenvolvimento da capacidade de gestão, no Projeto Sub-regional de Consolidação e Incremento da Capacidade Gerencial e no Programa de Capacitação em Gerência de Unidades Básicas de Saúde do Distrito Sanitário, têm sido feitos esforços para promover experiências, investigaçôes e reflexões sobre a capacidade de negociação, com o objetivo de promover o ajuste consensual no processo social de desenvolvimento das condiçōes de saúde.

Um dos resultados destes esforços é esta publicação, que tem o propósito de sistematizar enfoques, metodologias e técnicas capazes de produzir conceituação e instrumentação adaptadas às características da gerência em Saúde Pública. Além disso, oferece um material educativo para estimular e servir de base a processos de desenvolvimento desta nova e importante capacidade gerencial que é a negociação. 
Mesmo que a aplicação destes conceitos possa se dar em todos os níveis institucionais e em qualquer área de atividade, será enfatizada a sua utilização nos conjuntos sociais que formam os Sistemas Locais de Saúde. Assim, pretende-se fazer uma abordagem que relacione coerentemente, e de forma complementar, o processo de gestão, com enfoque estratégico da administração voltada para a promoção da participação social no desenvolvimento dos Sistemas Locais de Saúde.

\subsection{INTRODUC̣ÃO}

Socialmente, rever e transformar instituições de saúde é considerado instrumento de execução de políticas públicas voltadas para o desenvolvimento de conjuntos sociais concretos. No atual contexto de crise econômica, além da busca de novas formas de organizaçăo em rede e, em face dos recursos de saúde existentes em um espaço população, procura-se provocar um novo perfil de gestão desconcentrada que permita reorientar a atuação para a integração de todos os atores sociais em nível local, regional e nacional, em função dos objetivos comuns de produçăo de saúde pessoal e comunitária.

No contexto da crise econômica e social, acentuam-se os desequilíbrios entre problemas apresentados e os recursos disponíveis para solucioná-los. Isto intensifica os conflitos em busca de melhorar as condiçōes de vida. Além disso, os níveis aceitáveis de saúde que estabelecem os indivíduos e os grupos sociais são muito variáveis em função do perfil de desenvolvimento desejado. Nestas condições, delimitar e executar a missão do setor se converte em processo complexo de identificação e coordenação entre o conjunto dos atores institucionais, dentro e fora do tradicional conceito do setor saúde, e os demais atores sociais.

Também é importante assinalar que tem-se evoluído para uma nova conceituação de saúde:

A saúde tanto individual como coletiva é um produto de complexas interações entre os processos biológicos, ecologicos, culturais e econômico-sociais, que ocorrem na sociedade; neste sentido a saúde é, em grande medida, um produto das relaçōes sociais predominantes, determinadas por um processo histórico do qual é uma das manifestações. ${ }^{1}$

A saúde é, por excelência, o melhor indicador das condiçōes de bem-estar que justificam todo o trabalho social, incluindo dentro destes as atividades produtivas. $\hat{E}$ por esta razão que em lugar de falar-se de saúde e desenvolvimento da saúde versus desenvolvimento social, é preferivel falar da saúde no desenvolvimento, já que este não pode ser efetivado sem a participação dos setores mais estreitamente vinculados com as condiçóes de vida dos conjuntos sociais, os chamados setores sociais. ${ }^{2}$

1 Opas - Administração Estratégica Local. Washington, D.C., 1991.

2 Extrato do discurso do Dr. C. Guerra de Macedo, diretor da OPS, no II Fórum de Saúde e Desenvolvimento, S. J. Costa Rica, março/1991. 
O novo conceito de saúde é construído coletiva e socialmente. Responde a uma lógica complexa em que se articulam as visōes sociais e individuais, que transcendem os limites da Biologia ou da clínica para introduzir-se na dimensão do desenvolvimento humano.

O nível aceitável de saúde estaria, então, variando segundo as aspirações e as possibilidades reais de cada grupo e indivíduo na conjuntura particular.

O processo histórico saúde-doença e o sistema de saúde são parte de um processo social altamente complexo. Os problemas identificados são difíceis de separar, e as soluções, parciais na maioria das vezes, o que gera novos problemas. $\mathrm{O}$ sistema de saúde é altamente dependente de variáveis extremas, e a possibilidade de realizar ações necessárias para a produção de saúde depende, em última instância, do valor que a sociedade dá à saúde.

O redimensionamento da saúde no desenvolvimento imprime a urgência de tratar os problemas de saúde através da articulação inter-setorial, reunindo esforços dos setores governamentais do Estado, assim como o de atores não-governamentais e que, pela óptica do setor saúde, poderão alcançar um desenvolvimento integrado em escala nacional, regional e local. Não obstante, deve-se considerar que o progresso alcançado nos diferentes setores é bastante heterogêneo, e existem obstáculos para colocar em prática os processos de coordenação inter-setorial e de participação social causados por problemas institucionais, administrativos, políticos, financeiros, culturais e humanos. É preciso, então, identificar os problemas da área da saúde, seus componentes e os sistemas aos quais estão interrelacionados, para facilitar a descoberta de suas causas e determinar as intervenções indispensáveis, considerando a disponibilidade de conhecimento e recursos, tanto institucionais como comunitários, para ajustar uma atuaçăo integrada.

Por outro lado, para que haja uma articulação inter-setorial com participação social, é indispensável o reconhecimento do papel da política pública como instrumento de condução e administração. Isto demanda uma atitude aberta e transparente dos órgãos setoriais do governo e a busca de alternativas criativas e de curto prazo que possibilitem credibilidade e factibilidade para construir um ambiente propício para um processo de negociação, objetivando o consenso entre os que representam os diversos setores do governo e os da cidadania. Para definir as prioridades e o comprometimento político com a solução dos conflitos, é necessário que tanto os aspectos dos que têm poder de decisão como os dos que têm recursos para solucionar os problemas sejam considerados.

Assim, a situaçăo se torna mais complexa, já que é necessário integrar ações que são do domínio do setor saúde com as de outros que não o são, como habitação, trabalho, educação, agricultura, meio ambiente, trânsito, abastecimento, saneamento básico. Todas devem ser atraídas para que, com o setor saúde, possam traçar objetivos comuns e definir ações integradas. Merece ainda destaque dentro da instituição governamental o papel desempenhado pelos setores representativos das áreas-meio que constituem a estrutura burocrático-jurídica e que detêm poder facilitador ou complicador das açóes desejadas para promover o desenvolvimento do setor saúde. As atividades-meio constituem-se importantes atores nas consecuções das ações propostas e, quanto mais estiverem presentes $\mathbf{e}$ 
participantes dos processos coordenados pelo setor saúde, vivenciando a realidade e o contato com a população, melhor poderão contribuir para o êxito das propostas. São exemplos importantes destas áreas-meio os atores dos setores jurídicos, administração, recursos humanos. Não podem ser deixadas de lado, pela importância que representam no setor saúde, que é um setor de prestação de serviço, as representações sindicais e as lideranças do funcionalismo na formulação das políticas públicas bem como nas negociações relacionadas à valorização do trabalho dos profissionais de saúde. Fica claro que a capacidade resolutiva do gerente, no sentido de contribuir para o melhoramento do nível de vida da comunidade, demanda uma capacidade gerencial que permita 'conduzir processos' e 'administrar recursos' dentro de uma dinâmica de cooperação inter-setorial e de participação social.

Liderança e capacidade de negociação - reconhecidas pelas instâncias e atores envolvidos nos níveis local, regional ou nacional - assim como o estilo de gerência participativa e consensual, são facilitadores das açōes inter-setoriais envolvendo setores da saúde e de fora de seu âmbito de governabilidade.

Por outro lado, são fatores que limitam as ações integradas do setor saúde com os outros atores sociais, portanto fatores desintegradores, o manejo inadequado dos interesses em conflito protagonizados pelos atores envolvidos no processo de desenvolvimento social. A descentralização das ações em nível nacional requer flexibilização dos processos administrativos; rigidez institucional, barreiras interinstitucionais, ausência de planejamento horizontalizado e coordenando, falta de mecanismo de controle e avaliação em nível local são as principais contribuiçōes negativas para o desenvolvimento do setor saúde com controle social.

Tanto a liderança, como a negociação podem ser prejudicadas pela condição inadequada dos interesses em conflito. A capacidade de gestão está relacionada à habilidade de utilizar estes instrumentos. Quanto mais desenvolvida a capacidade de negociação, melhor poderá contribuir para a solução ou mediação dos conflitos inter-setoriais, promovendo assim, melhor utilização dos recursos para satisfazer interesses comunitários.

Conclui-se que as capacidades de gestão e condução integram a capacidade gerencial, o que implica:

- analisar e interpretar os contextos social, político, econômico e cultural;

- criar condições necessárias para a participação ampla de todos os atores e grupos sociais envolvidos;

- relacionar os tempos políticos e técnicos;

- desenvolver modos distintos de proceder em consonância com o momento político local e o contexto nacional;

- considerar a negociação como instrumento fundamental de ajuste gerador de consenso capaz de sustentar e viabilizar propostas de ação conjunta;

- orientar o desenvolvimento institucional e interinstitucional.

- dirigir e controlar a implementação das mudanças nos programas de trabalho, originados no processo de negociação. 
Levando-se em conta que a construção de viabilidade é um dos pontos fundamentais da atividade da gerência, sua análise, racionalização e as ações políticas deverão ser consideradas sempre dentro do processo de tomada de decisāo.

A análise de viabilidade implica nos seguintes elementos:

- identificação e análise de fatores favoráveis, desfavoráveis e restritivos durante a implantação e desenvolvimento da opção;

- análise de possibilidades e oportunidades de remoção dos fatores restritivos no período considerado; identificação, seleção e articulação das ações possíveis e eficazes;

- análise do impacto negativo de fatores restritivos e desfavoráveis sobre a estratégia e a opção selecionadas; avaliação do possível impacto sobre a condução do processo;

- análise da conjuntura e proposição de açōes que garantam viabilidade em curto prazo para a opção negociada. ${ }^{3}$

A identificação destes fatores se dá no transcurso da gestão das negociações e tem caráter dinâmico, modificando-se com freqüência nas suas características, de modo que a construção de viabilidade como ação gerencial não se dá linearmente, mas de forma empírica e assistemática.

Precisamente, a capacidade de negociação na instância de gestão procura a viabilidade da direção integradora para o desenvolvimento do processo de produção de saúde em nível nacional, regional ou local. Necessita do envolvimento dos múltiplos atores da área de domínio institucional do setor ou fora dela, para relacionar os problemas e necessidades dos grupos sociais aos conhecimentos e recursos disponíveis, ajustando as opções viáveis para as partes envolvidas.

Para o setor público, a capacidade gerencial e de gestão, partindo do pluralismo e da interdependência das instituiçóes, açōes e recursos, que devem interatuar complementando-se e orientando-se na mesma direção, exige a necessidade de incrementar a capacidade de negociação em busca do ajustamento.

Cada um dos níveis de gestāo deve ter autoridade e capacidade para estabelecer compromissos tanto no plano internacional, nacional como regional ou local dentro de um país, a fim de otimizar o uso dos recursos disponíveis em um âmbito geográfico específico e em tempo determinado.

$\mathrm{Na}$ negociação, busca-se harmonia democrática de interesses dos atores, que participam em igualdade de condiçōes, desde o nível local até o nacional, na solução dos problemas que os afetam.

Finalmente, o processo de negociação no setor público não pode ferir os princípios constitucionais da ordem pública, moral, indisponibilidade do interesse público e o da supremacia do interesse público sobre o interesse particular, uma vez que são os limites da legalidade e estabelecem as regras fundamentais para a vida em sociedade de forma democrática e civilizada.

3 OPS. Administração Estratégica Local. Washington, D.C., 1991. 
No caso do Brasil, é preciso também não esquecer que o (SUS) está regido por preceitos constitucionais e por uma legislaçăo normativa de âmbito federal que define o papel dos órgãos e dos atores gestores, bem como dos órgãos de controle social os Conselhos de Saúde.

Cabe, portanto, aos atores e gestores do SUS, em todos os níveis, ao habilitarem-se para estas funçōes, levar em consideração este arcabouço jurídico, sob pena de incorrer, dentro de um processo de negociação, em contratação ou comprometimento sem respaldo legal.

A seguir serão delineados alguns conceitos sobre negociação.

\subsection{CONCEITUAC̣ÃO}

De maneira geral e como ponto de partida, pode-se considerar a negociaçăo como um processo que pode permitir aos atores sociais analisar e compatibilizar as razões, interesses e atuações de sua participação na resolução de situaçōes complexas, e conseguir acordos duradouros como base de uma cooperação benéfica.

Para que estes atores sociais ajam de forma harmônica, é necessário compartithar dois tipos de informação:

- sobre a realidade nacional, regional e local, referente a problemas e recursos;

- a informação técnica dos programas relacionados a conhecimento e recursos.

Repartir estes tipos de informação incide diretamente na possibilidade de consenso entre tais atores.

Percepçōes opostas sobre as necessidades de recursos para resolver os problemas é o que gera conflito. Estas contradições podem provocar três maneiras de tentar resolver as necessidades comuns:

- uma das partes solicita colaboração, pois não pode resolver sozinha suas necessidades; outra, aceita e colabora;

- parte alguma aceita, deseja ou pode colaborar;

- as duas partes se dão conta de que, se ambas não colaborarem, será impossível fazer algo positivo.

Considerando o propósito de ampliar conceitos e instrumentos do processo de negociação para facilitar o acordo entre as partes envolvidas, dentro de uma linha de negociação democrática, serão discutidos alguns aspectos teóricos, aplicáveis para o desenvolvimento da capacidade gerencial do setor saúde.

Negociação é um processo mediante o qual duas ou mais partes com interesses comuns e opostos trocam informações ao longo de um período, tendo em vista conseguir um acordo em suas relações futuras.

Negociação não é sinônimo de regateio. Regateio é um processo limitado para trocar valores de bens ou serviços e não tem caráter duradouro.

Ao longo do processo de negociação, no entanto, alguns aspectos ou assuntos específicos podem ser regateados. 
Várias disciplinas acadêmicas têm contribuído para formular teorias sobre a negociação. Cada uma enfoca o assunto com premissas e metodologias próprias.

As ciências econômicas é que têm se preocupado mais com o assunto, o que reflete a importância do tema para o processo de desenvolvimento econômico. Assim, por exemplo, a maioria das teorias sobre negociação tem sido formulada em torno de dois tópicos:

- relações trabalhistas ou laborais para distribuição de valores entre patrōes e empregados;

- interações estratégicas entre empresas e um mercado oligopolizado.

Existem teorias que atendem a ambos os temas. Assim, economistas têm enfocado sua atenção nos seguintes problemas:

- estabelecer condições que devem ser satisfeitas por qualquer acordo entre partes;

- estabelecer se a partir deste conjunto de condições, pode-se alcançar um resultado único, ou se são possíveis várias soluções ou, pelo contrário, o conjunto de condições é inconsistente para a existência de alguma solução negociada.

O enfoque do problema da negociação corresponde à teoria dos jogos desenvolvidos por Von Neumann e Morgeterns em 1944. Dentro desta teoria, é possível descrever a qual acordo chegariam dois atores racionais.

Muitos autores trabalham com a teoria dos jogos para encontrar explicações e, portanto, conseguir predizer resultados dentro de um processo de negociação.

As posições teóricas dos autores são extensas e podem ser aplicadas nos vários campos de atuação profissional. A prática tem demonstrado que não há como estabelecer previsões determinísticas sobre os resultados possíveis.

A utilização desta conceituação teórica pode ser mais bem compreendida com a leitura do texto "O Plano como Aposta de Carlos Matus". 4 Este artigo foi desenvolvido para ilustrar as diferenças entre planejamento tradicional determinístico e planejamento estratégico situacional, mas pode ser utilizado na formação de negociadores. Nele, destaca-se a importância das relações: custo/benefício; certeza/incerteza; risco/segurança, que acompanha todos os atores nos processos de tomada de decisões. Destaca-se, ainda, a importância da interdependência dos atores no jogo do desenvolvimento social.

Na planificação tradicional, há ênfase ao determinismo e ao economicismo tecnocrático, cuja base científica é a teoria do controle de um sistema por um 'agente'; na planificação estratégico-situacional (PES), o fundamento é a teoria de um jogo semicontrolado, a serviço da prática racional da açăo humana.

4 Artigo publicado pela Fundação Sistema Estadual de Dados (SEADE), na Revista São Paulo em Perspectiva, v.5(4). 


\section{O Jogo da Corda Elástica e do Sino}

Para entender o que é um jogo semicontrolado, assuma-se como metáfora este problema bem simples. Você, o jogador 1 , tem uma corda elástica de $1,5 \mathrm{~m}$ de comprimento. No meio da corda está amarrado, pendente a um fio curto, um sininho que, por ser muito sensível à instabilidade, emite seu ruído a qualquer movimento. O jogo consiste em tomar a corda pelos dois extremos e esticá-la, tentando reduzir ao mínimo o tempo em que o sino toca. Se você é o único jogador, o problema parece fácil. Só depende de você não fazer movimentos desnecessários, e você decide quando a corda elástica está suficientemente esticada. Agregue-se, então, o jogador 2 . Agora, você segura só um dos extremos da corda e o jogador 2 segura o outro. Suponha que ambos cooperem. Mesmo assim, o problema já é mais difícil. O menor 'movimentozinho' do outro jogador pode impedir seu objetivo. Tampouco será fácil um acordo sobre o conceito de 'corda suficientemente esticada'. Juntem-se, a seguir, mais dois jogadores, de modo que os quatro, em certos momentos, desejem cooperar para alcançar o objetivo e, em outros, tratem de impedir que se mantenha o sino estável e silencioso.

Agora, quanto depende do jogador 1 a meta de estabilizar o sino? Quanto pesam os movimentos de 2, 3 e 4 no alcance do objetivo? Este é um jogo cujo resultado depende apenas em parte da açăo de 1 . Neste caso, o cálculo que deve fazer quem queira impedir que o sino toque é um cálculo não bem estruturado, que supera as possibilidades da moderna matemática, e o plano com base neste cálculo quase estruturado é uma aposta com certo grau de vulnerabilidade. O jogo social, sem dúvida, é muito mais variado e complexo do que este, porque, entre outras razões, compôe-se de muitos subjogos sobre os quais o jogador 1 tem mais ou menos controle.

A principal característica do que se denomina jogo semicontrolado está no seguinte: há aspectos e momentos do jogo em que, apesar dos outros jogadores, podem-se calcular resultados com alta margem de segurança ou de probabilidade. Se o sino está estabilizado, por exemplo, basta que os jogadores se abstenham de fazer movimentos para que permaneça silencioso. O sistema torna-se mais previsivel. Mas há outros aspectos e momentos do jogo em que só se podem fazer apostas condicionadas à ocorrência de determinadas circunstâncias e decidir apenas na base de preferências quanto a algumas apostas, pois o cálculo de resultados é impossível. Por exemplo: o sino está tocando e todos tratam de fazer movimentos para estabilizá-lo, com resultados imprevisíveis. Neste último caso, o futuro é nebuloso, difuso e indeterminável. Não se pode calcular o risco de uma jogada ou decisão. A incerteza é inexorável. O que o plano anuncia é aposta débil.

Para compreender a teoria da planificação é conveniente, portanto, distinguir sistema controlado de semicontrolado.

O sistema é controlado por um jogador se os outros participantes do jogo têm comportamentos predizíveis e se propōem utilizar ao máximo os limitados recursos de que dispōem, para aumentá-los a cada nova jogada. Trata-se de cálculo científico, apoiado no conhecimento das leis de comportamento dos outros jogadores que cooperam e competem pelos mesmos recursos, cujo estabelecimento é indispensável 
para se alcançar objetivos que também são cooperativos e conflitivos. Neste caso, o suporte essencial para tomar uma decisão é o cálculo estruturado, que permite ao jogador no controle anunciar com certeza, resultados determináveis, ou probabilidades objetivas. No 'jogo-da-velha', por exemplo, não se tem controle sobre as decisões do oponente, mas se pode fazer uma previsão precisa de todas suas possíveis jogadas. O mesmo se dá com o adversário. Trata-se de um jogo estruturado. Algo parecido ocorre com um modelo econométrico cujo criador conhece a conduta dos agentes econômicos.

Em contraposição, o sistema é semicontrolado se todos os jogadores participantes são estrategistas criativos que cooperam e entram em conflito pelos limitados recursos que o resultado do jogo distribui em cada momento. Nesse caso, o suporte essencial para se tomar uma decisăo no jogo é o julgamento do apostador, fundamentado, parte por cálculos parciais bem-estruturados, parte por preferências explícitas quanto aos aspectos nebulosos ou não bem estruturados. $O$ julgamento do apostador pode refinar-se, explorando a eficácia de nossas açōes, ou seja, seus resultados, em diversos futuros possíveis que se desenvolvem em variadas circunstâncias ou cenários. No jogo da corda e do sino, por exemplo, o jogador 1 não tem capacidade alguma de predição e sua capacidade de previsão é incompleta e imprecisa quanto aos movimentos dos outros jogadores.

Na vida real, governa-se e planifica-se em um jogo semicontrolado, e isto altera todas as bases de pensamento sobre a planificação.

\section{No Jogo Social, o Futuro é Nebuloso: não é previsível}

O aspecto incontrolável do jogo social é que todos os jogadores têm limitações de informação e recursos para tentar ganhar o jogo e, mesmo com abundância de recursos econômicos, não podem comprar boa parte dessa informação. Parte muito importante da informação de que os jogadores necessitam para jogar com eficácia não pode ser obtida mediante investigação ou espionagem. Os jogadores, portanto, não sabem com certeza como superar essas limitações, pois, em cada momento do jogo, tampouco sabem se a jogada seguinte será mais eficaz. Não se pode comprar ou espionar uma informação que outrem não possua.

Nenhum jogador pode raciocinar de modo determinístico: 'se decido A, a conseqüência é B '. De outra maneira, não seria jogo, mas um sistema controlado. $E$ isto é válido, embora o jogo social seja desigual e outorgue a uns muito mais poder do que a outros.

Não obstante, em duas condições extremas e concomitantes é possível reduzir, teoricamente, a incerteza inexorável e convertê-la em certeza: a) se um jogador controla todos os recursos limitados de um jogo e transforma seus oponentes em servidores; b) se o jogo é completamente independente dos outros jogos que se desenvolvem ao mesmo tempo. Esse extremo, no entanto, é mera curiosidade teórica que define a zona fronteiriça entre jogo e sistema controlado. $\mathrm{Na}$ vida real política, econômica, cognitiva, social, nenhuma das duas condições mencionadas é alcançável por um jogador. 
Este jogo difuso e nebuloso tem os seguintes ingredientes de incerteza:

- Ignorância sobre o futuro daquela parte do mundo que supomos regida por leis ainda desconhecidas ou não esclarecidas pela ciência. É o aspecto de incerteza originado pelo desconhecimento da natureza e dos processos sociais em que vigora a lei dos grandes números. Investigação, estudo, capacitação e treinamento podem reduzir esta primeira limitação. Hoje, por exemplo, não se conhecem as leis do desenvolvimento da AIDS. Mas, no futuro, por meio da investigação, é possível que se descubram essas leis. É possível, também, que um ator monopolize certos conhecimentos em detrimento de outros.

- Criatividade dos jogadores, irredutível mediante informação e conhecimento, porque estes recursos alimentam mais rapidamente a própria criatividade do que a capacidade humana de predizê-la. É o aspecto interativo e mais fascinante do jogo. A criatividade é uma característica da interação humana entre poucos. Eu jogo ' $X$ '; qual será a jogada seguinte de meu oponente? Qual será minha resposta a essa hipotética jogada? Esta é a essência da interação criativa, em que cada jogador é um bom ou um mau estrategista. Este cálculo, por definição, não segue leis e gera uma incerteza que não se reduz, de forma expressiva, com mais conhecimentos. $O$ surpreendente e o inimaginável descontrolam os planos dos jogadores. Também dificulta o jogo a multiplicidade do futuro imaginável, diante da necessidade de apostar numa variedade muito reduzida de possibilidades. Se as possibilidades são milhares, como apostar nas duas ou três mais relevantes? Esta incerteza é inevitável. Um jogador pode estar mais ou menos preparado para prever e reagir ante esta nebulosidade do futuro, mas não pode evitá-la na vida prática.

- Opacidade da linguagem, que, muitas vezes, torna ambíguo o intercâmbio de significados nas conversações entre jogadores. O jogador 1 pode 'falar A' e o jogador 2 'escutar $B$ '. No jogo de bridge, esses erros de conversação são muito comuns, pois fala-se, principalmente, pelas próprias jogadas e estas admitem mais de uma interpretação. No jogo social ocorre algo parecido. Como saber se a ameaça de uma greve, uma renúncia ou uma guerra é real ou uma fanfarronada? Por isso, existe uma dimensão lingüística na nebulosidade do jogo social.

- No jogo maior, ou no contexto em que se situa o jogo particular, não se tem controle ou capacidade de predição. Quando muito, dispõe-se de limitada capacidade de previsão sobre o contexto ou circunstâncias que cercam e condicionam nosso jogo. Aqui, 'previsão' é uma predição condicionada que começa com a conjunção 'se' precedendo as circunstâncias em que se situa o plano. Os jogadores escolhem seu plano de jogo, mas não as circunstâncias em que devem realizá-lo.

Nesse nicho de incerteza, os jogadores entram em cooperação e em conflito e, assim, surgem problemas de relações no interior do plano de um ator, e de relações externas entre os planos dos diversos jogadores. No nível dos objetivos do plano, por exemplo, podem verificar-se as interaçốes já descritas. 
O conflito de planos e objetivos é fonte de incertezas, pois a eficácia da jogada de 1 depende do que tenha jogado 2 antes e do que jogue depois. Contudo, mesmo na cooperação entre jogadores, há incerteza, porque nem sempre é fácil decidir quanto à jogada de mútua conveniência.

Neste jogo, em cada momento de seu desenvolvimento, os jogadores podem comparar os objetivos a que se propuseram com os resultados, isto é, com os objetivos alcançados. Ao avaliar os resultados, cada um identifica problemas. Assim, um problema para um jogador é o resultado insatisfatório que, em determinada data, o jogo the oferece. Portanto, é natural que um problema para o jogador 1 possa ser justamente um bom resultado para o jogador 2. O problema sempre é relativo a um jogador. Não obstante, há uma exceção: os problemas que provêm de beneficiários do jogo $\mathrm{B}$ que afetam negativamente $o$ jogo $\mathrm{A}$. Neste caso, surgem problemas comuns a todos os participantes do jogo $\mathrm{A}$.

\section{Aprender a Jogar}

Se deseja alcançar bons resultados, o governante deve aprender a jogar no jogo social. O que significa jogar bem? Esta é a pergunta-chave para a teoria de governo e a planificação, porque manejar bem não apenas implica o domínio intelectual da complexidade do jogo semicontrolado, como, principalmente, a arte de jogar bem a capacidade de, na prática, medir-se com os outros jogadores e dominar a tensão que o jogo produz em uma situação concreta.

Aqui pode-se tratar apenas do problema do domínio intelectual da complexidade do jogo semicontrolado. O outro aspecto, mais importante ainda, requer mestria artística, vocação e aptidões só provadas na prática política e conseguidas mediante treinamento perseverante. Um estadista precisa ter domínio, tanto intelectual como artístico, sobre o jogo semicontrolado.

Em síntese, pode-se dizer que o domínio intelectual da complexidade do jogo semicontrolado apresenta quatro grandes problemas:

- saber explicar a realidade do jogo;

- saber delinear propostas de ação sob incerteza;

- saber pensar estratégias para lidar com os outros jogadores e com as circunstâncias, para calcular bem o que se pode fazer, em cada momento, em relação ao que se pode fazer para alcançar os objetivos;

- saber fazer no momento oportuno e com eficácia, recalculando e completando o plano com improvisação subordinada.

Nesses quatro aspectos, $\mathrm{o}$ jogo semicontrolado desafia nossas crenças e conceitos tradicionais e nos obriga a ampliar o vocabulário para melhorar a qualidade de nossa prática de governo. ${ }^{5}$

5 No texto original, relaciona-se uma série de autores que trataram da questão das negociaçōes como instrumento de desenvolvimento social. Tal desenvolvimento decorre sempre da interaçāo inter-institucional ou entre grupos sociais, em busca do melhor ponto possível de acordo entre as partes, para o estabelecimento de contratos duradouros. A lista destes autores e textos encontra-se ao final desta seçăo. 
Vale a pena registrar ainda alguns conceitos de Steele, Murpy \& Russil (1991), ${ }^{6}$ para ampliar a conceituação e a aplicabilidade deste instrumento pré-histórico chamado 'negociação'. Herb Cohen, autor norte-americano, afirma: "nosso mundo real é uma gigantesca mesa de negociações e, desejando ou não, você é um participante".

Os leigos conceitos sobre a matéria com freqüência não diferenciam negociação de discussão, acordo ou barganha.

São definiçōes freqüentemente utilizadas para negociação:

- processo mercantil de dar e receber, por intermédio do qual as condições de uma transação são acertadas e implementadas;

- esforço de duas ou mais partes para realizar uma transação por barganha;

- diálogo com a outra parte ou partes, com o propósito de se chegar a um acordo.

- reunião com o propósito de conferir e permutar pontos de vista, chegar a um acordo conciliatório e barganhar ou transacionar entre si por intermédio do dar e receber.

Utiliza-se também o termo 'dissídio coletivo' para descrever o processo de negociação entre gerência/sindicato, o que não é totalmente correto, pois não há possibilidade de barganhar.

Estas definições não estão totalmente incorretas, mas incompletas. Abrangem uma visão limitada de um processo complexo.

Termos como 'compromisso', 'troca', 'barganha', 'compensação', 'transação' e outros não são sinônimos de 'negociação'; constituem parte do processo. Pode-se negociar e chegar a um acordo sem assumir compromisso. Da mesma forma, as duas partes poderão transacionar sem negociar: ambas negociarão somente quando surgirem pontos de vista/objetivos divergentes.

\section{Uma Definição Utilizável de Negociação}

Negociação é um processo em que as partes envolvidas se deslocam de suas posições originais, inicialmente divergentes, para um ponto no qual o acordo possa ser realizado.

$E$ as partes se deslocam usualmente de suas posições, inicialmente divergentes, em decorrência de um ou mais dos seguintes conceitos:

- Acordo - implica busca de um fundamento intermediário, um processo no qual as partes fazem concessões até chegarem ao acordo.

- Barganha - é o momento em que as partes relacionadas à negociação permutam alternativas. Elas dão e recebem, e cada uma faz suas concessōes.

6 Negócio Fechado! A Arte da Negaciação (Ed. Makron/Mc. Graw). 
- Coerção - negociadores em posição privilegiada tentarão compelir a outra parte ou partes a um acordo. Se usada de forma inadequada, poderá se tornar contraproducente.

- Emoção - o papel da emoção na negociação é compreendido de forma ineficiente em muitos países ocidentais. No entanto, o principal determinante do comportamento dos negociadores consiste em como eles se sentem diante da outra parte, quão veemente ou imparcialmente eles formam suas conjecturas e como reagem diante de artimanhas de negociação - com surpresa, raiva...

É lógico que todos nós sustentamos certas concepções que poderão ou não estar inteiramente fundamentadas nos fatos: preconceitos são posições emocionais, não racionais. Os bons negociadores empregam emoção controlada como parte dos seus arsenais; porém, devem ter muito cuidado com o preconceito.

- Raciocínio lógico - todos gostamos de nos considerar pessoas racionais. É difícil, neste caso, que possamos ser embaraçados com facilidade por um argumento bem colocado. Negociadores empregam o raciocínio lógico para sustentar suas posições e, se possível, enfraquecer a posição da outra parte. Quanto mais real a elaboração do problema, maior o cuidado na busca de uma posição de suporte do negociador $\mathrm{e}$, em conseqüência, maior a probabilidadedade de que a lógica vença a batalha - a menos, é claro, que a outra parte saiba se opor.

A citação destes conceitos, extraídos de um livro destinado a empresários, comerciantes e executivos, tem a finalidade de chamar a atenção para a importância de sua aplicabilidade nos processos de gestão no serviço público.

Năo estamos habilitados a pensar como negociadores quando ocupamos a função de dirigentes do setor público de saúde. No entanto, basta observar melhor que há semelhanças entre as atividades gerenciais do setor público e do setor privado, a não ser a busca do lucro.

O setor saúde é grande consumidor de materiais e medicamentos com tecnologia sofisticada de prospecção, produção e comercialização, o que implica volumosos recursos de todas as ordens: cognitivos, financeiros, econômicos e comerciais disponibilizados pela sociedade para este setor.

Por se tratar de um setor de serviços, emprega grande número de profissionais especializados: aproximadamente 150 especialidades técnicas convivem dentro de um hospital terciário. As atividades corporativas e sindicais são intensas e permanentes. As instalações físicas e os equipamentos utilizados para diagnóstico, tratamento e armazenamento de informações săo sofisticados e caros.

A mídia é forte veiculadora e instrumento poderoso de formulação de conceitos de saúde e de doença, amplamente divulgados para a população.

Os conflitos decorrentes da ação da saúde pública em defesa do meio ambiente envolvem atores sociais poderosos e interesses mais poderosos ainda.

Questóes relacionadas à bioética apaixonam pesquisadores de todas as áreas. Sua interface com as religiōes e seus atores não pode ser relegada a segundo plano. 
O surgimento de novas doenças e métodos de diagnóstico e tratamento são desafio constante para todos os que participam do processo decisório.

Doenças decorrentes da atividade profissional abrem um campo de conflito permanente na sociedade, envolvendo trabalhadores, empresários, sindicatos e profissionais de saúde.

A assistência aos chamados doentes mentais ou à saúde mental passa por profunda reformulação, acirrando posiçōes de atores sociais.

Criminalidade, mortes violentas, urbanização, enfim, todos os problemas de uma sociedade refletem-se em uma unidade de saúde pública.

Diante deste quadro, na posição de dirigente de um segmento deste gigantesco emaranhado de interesses, não há como abordar com racionalidade e justiça os conflitos provocados por esta constante interação de atores sociais, a não ser por meio de um interminável processo de negociação permanente, coletivo e democrático.

Por isso tudo, defende-se, aqui, o conceito de negociação para o setor público de saúde contido no texto:

A negociação é um ato político, para que a gestão de políticas públicas busque gerar a viabilidade por meio de acordos duradouros e respeitados, em determinado tempo e espaço geográfico. Estarão envolvidos atores sociais - institucionais ou nāo - que têm interesses, poder e recursos para enfrentar situações-problema que os afetem com direitos e possibilidades

de participar responsavelmente e em pé de igualdade na solução.

\subsection{O PROCESSO DE NEGOCIAC̣ÃO}

Geralmente, na prática gerencial setorial, não se conta com cultura, capacidade ou instrumentos que orientem a melhor forma de aprofundar a análise e a compatibilização das posiçōes, a fim de satisfazer as reais necessidades dos oponentes em uma negociação no contexto da gestão do setor saúde.

Sem dúvida, na atualidade, existe instrumental técnico para isto, que também pode ser utilizado para especificar o uso de estratégias na aplicação concreta de táticas que possam facilitar tais processos. Além do que, as instâncias e os dirigentes podem realizar auto-avaliação sobre a forma de negociar e encontrarão novas táticas para alcançar melhores resultados.

Na prática, qualquer conjunto de recomendaçōes para gerenciar negociaçōes depende, em boa medida, da existência de enfoques realistas deste processo. Sem dúvida, em muitas das teorias formais há uma visão excessivamente abstrata sobre o processo, ignorando aspectos que podem ter grande importância. Por exemplo, não é levada em conta a possibilidade de desacordo interno das equipes de negociação; tampouco a possibilidade de que as preferências das partes podem variar durante o processo de negociação.

Por estas razões, é conveniente destacar algumas das características mais críticas na prática do processo de negociação. 


\section{Características}

\section{A Informaçāo está Assimetricamente Distribuída}

As partes não têm o mesmo conhecimento ou percepção em relação ao objeto de negociação. Um primeiro objetivo da negociação é conhecer as intenções da contraparte, assim como a natureza do que se oferece. A negociação é uma via privilegiada para obter estas informações. $O$ material do processo pode levar a conclusóes de que é desnecessário ou inconveniente chegar a um acordo, seja porque cria amarras desnecessárias ou porque se descobre que o que vai ser obtido não tem utilidade. Em outras ocasiōes, a informação transferida é tão significativa que se torna necessário subscrever acordos de confidenciabilidade, antes de continuar as conversaçōes. Em outros casos, como nas contrataçōes coletivas, ambas as partes sabem razoavelmente bem o que é que se deve negociar, assim como as demandas mínimas do outro, porém não estão seguras sobre as expectativas dos resultados.

\section{Os Atores em Negociação são Complexos}

Isto implica que boa parte do processo é interno. Ocorre dentro da própria equipe de negociação, para clarear as posições compartilhadas pelos seus membros. Na prática, esta necessidade pode consumir grande parte do tempo e da energia da equipe e debilitar sua posição. Outras conseqüências deste problema são o prolongamento exagerado do processo e o fortalecimento da contraparte, que procurará explorar a situação, forçando o jogo sobre os membros da equipe cuja posição seja mais próxima da sua.

\section{Os Aspectos da Negociação săo Complexos}

Objetos ou matérias de negociação devem ser analisados por partes, resultando em um processo entrecortado, descontínuo e errático. Não se pode esperar que uma negociação termine em uma única reunião, mas é inoportuno que o processo caminhe por reuniōes muito prolongadas ou que se dê por uma sucessão de rodadas, cada qual com um grupo diferente de negociadores. O manejo do tempo é ferramenta fundamental e não deve se transformar num jogo de resistências para ver quem agüenta mais tempo em reunião.

Devem-se avaliar os resultados desejados, considerando-se o conjunto da matéria em negociação, bem como o que representa cada cláusula, suas interfaces e até mesmo cada uma delas em relação a aspectos externos ao processo em andamento.

\section{Incerteza Estrutural}

Em uma negociação, a incerteza provém de duas fontes. Em primeiro lugar, se desconhecem as próprias opções, uma vez que, em boa medida, dependem da proposta da contraparte. Em segundo, mesmo quando já se escolheu uma opção, persiste, ainda, a dúvida quanto aos seus resultados na prática. A dupla incerteza complica muito o processo: se não se sabe o que se vai negociar, muito menos podem-se avaliar seus custos e riscos. 
Estas quatro características, em geral, não são observadas pelos teóricos da negociação. Freqüentemente avalia-se apenas o resultado formal do processo. Concentra-se a atenção apenas sobre os termos do acordo final, deixando de lado um aspecto muito importante, e que é, em boa medida, o verdadeiro resultado do processo, já que o ocorrido durante a negociação é o que realmente define a natureza da relação entre as partes.

\section{Etapas do Processo}

Pelo menos quatro passos, não ne essariamente consecutivos, compöem o processo:

\section{Primeiro Passo: pauta ou agenda}

A primeira etapa a ser definida pelas partes é a pauta ou agenda da negociação.

Nesta fase, discutem-se os aspectos que serão debatidos e em que ordem. Dentro das equipes, procura-se definir com precisão o significado dos termos a serem utilizados. Os conceitos precisam estar claros. Não é raro haver necessidade de redefinição de termos e conceitos por insistência de uma das partes. Também se transmite e se processa muita informação de parte a parte, principalmente em relação às aspirações das contrapartes. Neste momento, testa-se a energia dos atores para enfrentar as situações partindo-se de um problema comum. Procura-se descrever o problema com precisão, verificando se é realmente uma questão que demande a atenção comum das partes em negociação, avaliam-se a capacidade de cooperação, conseqüências positivas e negativas, afetados e beneficiários, fatores causais e a adesão das partes à matéria a ser negociada. Trata-se de identificar os interesses em comum em relação ao problema.

Este momento é crucial para criar um ambiente propício para a negociação, com atores, local e horário apropriados, gerando um clima de confiança mútua.

Podem ser usadas técnicas de investigação-ação para definição do problema.

\section{Segundo Passo: definição}

Nesta etapa, busca-se definir o objeto da negociação ou matéria negocial e o conjunto de regras que deverão regular os padrões de comportamento das partes durante todo o processo. Define-se, portanto, o quê e como se vai negociar. É neste momento que se procura diagnosticar o que os atores querem e o que podem fazer em relação ao objeto de negociação, relativizando posturas, manifestações e posições das partes e relação ao contexto histórico, cultural e político.

Verificam-se, também, as expectativas das partes em relação ao custo-benefício que a negociação pode gerar.

As metas e suas viabilidades são avaliadas e discute-se o quanto o processo de negociação pode contribuir para sua ampliação.

Define-se, portanto, a direção do processo. 


\section{Terceiro Passo: ajuste dos interesses conflitantes}

Nesta fase, define-se o pacote de cláusulas possíveis de um acordo parcial. A experiência adquirida nas etapas anteriores ajudará na definição de linhas de comportamento e limites nem sempre explicados, mas subentendidos.

Começa a ser delineado o conjunto de protocolos, ou de acordos parciais sobre questões específicas, que poderiam ser chamadas de acordos sobre questões ou cláusulas específicas.

Cada parte tenderá a trabalhar cooperativamente em função dos acordos, que incluem os pontos considerados estratégicos, facilitando a composição do resultado final, no sentido favorável aos objetivos e metas globais delineados. Haverá a tendência de resistir ou dificultar a discussão sobre pontos que podem provocar dificuldades futuras - por diminuição de ganhos no resultado final daquela negociação, ou porque a equipe terá dificuldades em aprová-los no interior da instituição que representa.

As partes se encontrarão diante de alternativas complicadas e tentarão levar vantagem em todas as cláusulas. Persistindo esta posição, o conflito pode tornar-se grave. Se não houver alinhamento dos interesses conflitantes em direção a um resultado final favorável a ambos, o processo pode: a) ser interrompido pois o conflito caminhará para o confronto; b) uma das partes impōe uma derrota à outra; c) o processo terminará sem ter ocorrido negociação efetiva.

Quando as partes percebem que é possivel buscar alternativas, surgem novas idéias que, quanto mais numerosas e criativas, mais contribuirão para a possibilidade de resultado favorável com ganhos para todas as partes envolvidas.

É neste momento que a habilidade, inteligência, criatividade, experiência prévia e visão estratégica de processo têm possibilidade de se manifestar.

Aspectos culturais e históricos do contexto social influenciam, e muito, nesta fase do processo. Preconceitos, visão sectária, maniqueísmo, emoçóes negativas como raiva e ódio podem impedir a evolução do processo negocial.

O negociador habilidoso, imbuído da idéia de cumprir seu papel de dirigente público, deve ter em mente alguns conceitos, princípios e valores que o ajudarão a decidir e propor novos pontos. A primeira pergunta que the deve vir à mente é: "O que está sendo proposto beneficia ou prejudica o usuário da instituição que eu represento?" A segunda é: "Isto está de acordo com o projeto ou com a política da minha instituição ou do governo?" Em terceiro lugar: "Como reagirão meus funcionários a esta proposta?" Concomitantemente a isto tudo, deverá responder: "quanto isto vai influir na eficiência, eficácia, efetividade e eqüidade dos serviços prestados pela minha unidade?"

A capacidade de responder a estas perguntas facilitará a atuação do negociador e fará crescer a auto confiança, necessária para superar esta etapa.

Existem técnicas que ajudam a disciplinar as ações nesta fase da negociação, como o diagrama circular cujo modelo está apontado a seguir. 


\section{Quarto Passo: compromisso}

Nesta fase, os acordos parciais conseguidos na mesa de negociação devem ser submetidos à apreciação das bases institucionais representadas, para avaliação e ratificação. É possível que seja necessário rediscutir pontos já acordados na mesa durante as etapas anteriores, mas que não foram suficientemente compreendidos ou aceitos dentro das organizaçōes representadas.

Esta tarefa final será muito facilitada se as pessoas, sócios, cidadãos, governantes, técnicos, usuários, pacientes ou quem quer que esteja sendo representado na mesa de negociação, tiverem acompanhado passo a passo o que estava sendo decidido em seus nomes.

Cláusulas e protocolos aprovados por consenso são reunidos e trata-se de produzir novos acordos que garantam o cumprimento, o equilíbrio e a justeza do acordo final.

O acordo será mais duradouro e benéfico se houver consenso das partes, sobre:

- os benefícios estão bem distribuídos se houver cumprimento dos compromissos assumidos;

- os riscos políticos, sociais e financeiros são equivalentes;

- estăo previstos incentivos para continuar a cumprir os compromissos;

- a ruptura do compromisso por uma das partes implica risco. Finalmente, devem ser estabelecidos os mecanismos de controle e avaliação dos compromissos assumidos.

Atendidas todas estas exigências processuais, passa-se à elaboração de um documento formal, que, no caso do setor público, passará a ter valor legal e normativo das ações deste processo de negociação. Este documento em linguagem jurídico-administrativa recebe várias denominações. As de uso mais freqüente são contratos, protocolos, convênios, termo de compromisso, acordos. Outras vezes, os compromissos estabelecidos pelas partes obrigam a elaboração de instrumentos normativos dos Poderes da República - Executivo, Legislativo e Judiciário. São exemplos: decretos, portarias, normas, ordem de serviços para o Executivo; leis, que dependem de aprovação no Legislativo; as petiçōes, sentenças, documentos do Judiciário.

Para o setor privado, todos os acordos e compromissos são válidos, desde que não infrinjam a lei; para o setor público, só é válido o que está prescrito pela lei. Esta afirmação implica que se quisermos que o processo de negociação redunde em compromissos duradouros, teremos de utilizar os instrumentos formais do Estado. 


\section{Etapas do Processo de Negociação}

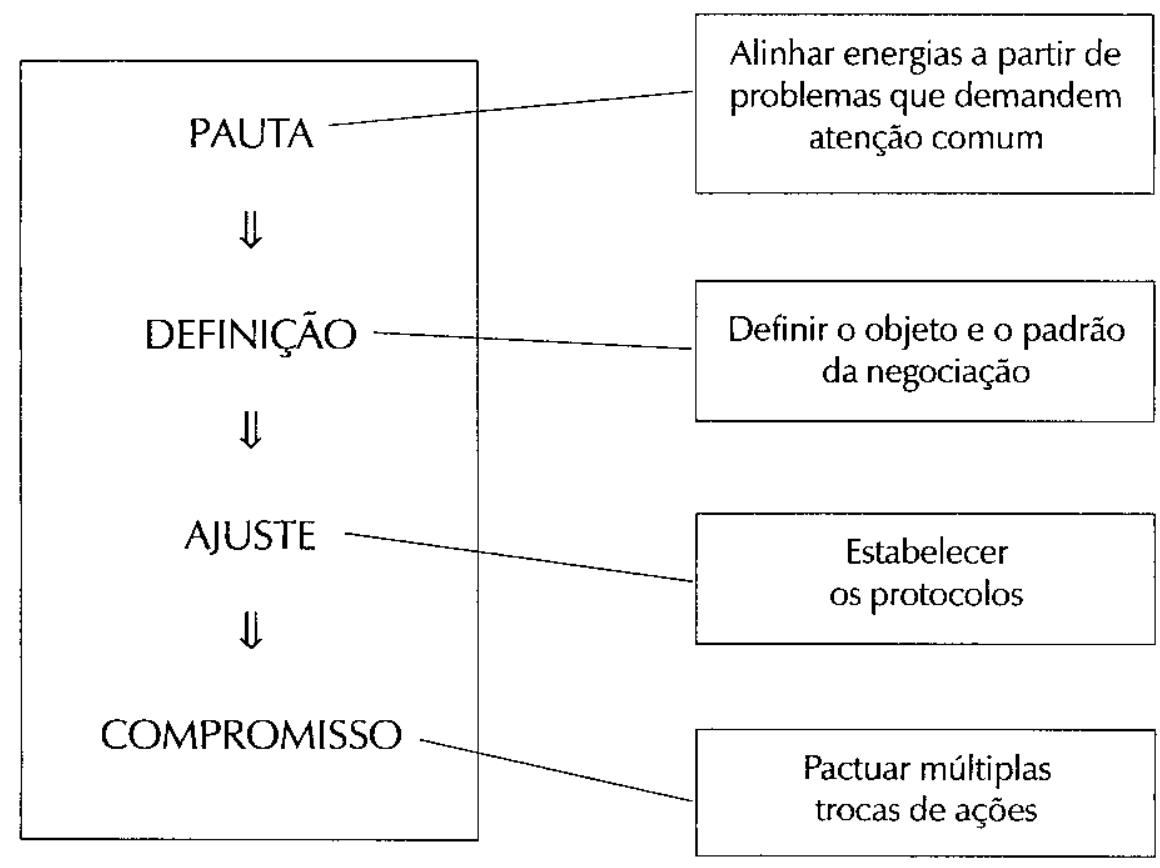


Quatro Passos para Gerar Opçōes

O QUE ESTÁ MAL

O QUE SE PODE FAZER

PASSO II: ANÁLISE

Identifique e classifique os sintomas do problema.

Sugira as causas prováveis.

Identifique as dificuldades para resolvê-las.

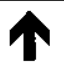

\begin{tabular}{|c|} 
PASSO IV: OPÇÕES \\
O que poderia fazer? \\
Que ações específicas \\
poderiam ser \\
executadas para resolver \\
o problema?
\end{tabular}

PASSO III: ENFOQUES

Quais as soluções teóricas?

Quais as possíveis estratégias?

Gere uma gama ampla de idéias para a solução.

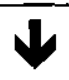

PASSO I: PROBLEMA

O que está perturbando?

Quais as conseqüências atuais?

Quais os efeitos futuros não desejáveis?

NA TEORIA: PASSOS II e III

NA PRÁTICA: PASSOS I e IV 


\subsection{POSIÇÕES, TÁTICAS E TÉCNICAS DE NEGOCIAC̣ÃO}

Um processo de negociação ocorre sempre em dois níveis. No nível explícito, aborda-se diretamente a matéria negocial; no outro, em geral de maneira não explicitada, trata-se da forma como $o$ assunto será negociado.

Paralelamente, cada movimento dentro do processo de negociação trata da matéria principal e vai estabelecendo as regras do jogo, o que pode servir para consolidar a forma e, de maneira mais ou menos consciente, contribuir para modificá-la.

Este segundo nível de negociação pode passar despercebido dentro do processo, incorporando-se quase de forma inconsciente ao conjunto de decisões tomadas pela mesa de negociação. Quando se está negociando com equipes de valores culturais muito diferentes, surge a necessidade consciente de estabelecer estas regras.

No caso de mesas de negociação com caráter permanente - do tipo negociação coletiva do contrato de trabalho -, este conjunto de regras normatizadoras do processo poderá constituir um dos protocolos a serem pactuados pela mesa. Tais regras, no entanto, poderão ser acordadas no decorrer do processo, acompanhando sempre seu avanço ou retrocesso do ponto de vista político e da confiança gerada de parte a parte. As táticas e técnicas são constituídas por padrões de decisão e conduta estudados experimentalmente, e que podem contribuir para um melhor desempenho dos negociadores.

Alguns princípios básicos devem ser destacados antes de se estudar táticas e técnicas. Estes princípios orientam as posições e os modos de negociação no processo de tomada de decisóes:

\section{Princípios para o Gerenciamento do Processo de Negociação}

\section{Seleção Estratégica do Modo}

Reconhecem-se três modos básicos de negociar, cada um associado a uma estratégia básica: concessão unilateral, competitivo e coordenativo.

O modo de concessão unilateral corresponde a uma estratégia de reduzir a distância entre as demandas das partes por iniciativa de um dos lados. No competitivo, uma parte pressiona permanentemente a outra, com objetivo de retirar ganhos, mesmo que tenha de usar técnicas de manipulação e engano; no coordenativo, estabelece-se uma postura de colaboração entre as partes para reduzir as diferenças e atenuar o conflito, por intercâmbio de informaçôes ou de recursos.

Do ponto de vista prático, é importante ressaltar que não há possibilidade da coexistência dentro do mesmo processo de negociação. Cada um deles provoca postura psicológica dos negociadores fundamentalmente diferente, o que impede não só o uso concomitante destes modos, como também torna muito difícil mudança para outro modo na mesma mesa. Tampouco é possível, ainda, que uma das partes assuma uma postura e outra use outro modo de posicionar-se dentro do processo. É, portanto, importante que esteja claro qual é o modo que prevalece para aquele processo. 
Os acordos obtidos a partir de negociação no modo coordenativo tendem a ser mais satisfatórios e duradouros. Os outros dois indicam sempre relação desigual entre as partes, implicando em imposições e não em equilíbrio.

\section{Metas e Expectativas}

Săo necessárias duas condiçōes básicas para o comportamento coordenativo:

a) ter como propósito e meta colaborar com a outra parte;

b) expectativa e confiança na cooperação da outra parte. Estas condiçóes se potenciam mutuamente. $O$ simples fato de se unirem condiçóes bilaterais para afastar-se dos modos competitivos ou de concessão unilateral já significa um avanço em direçăo ao consenso.

Existe ainda a necessidade de compreender o significado da palavra consenso. De modo algum deverá ser utilizada como sinônimo de cooptação ou de conluio. O consenso pode ser definido afirmativamente como conjunto de decisões que podem ser tomadas, sobre determinado assunto ou ponto em conflito, levando-se em consideração a correlação de forças entre partes envolvidas.

\section{Alta Demanda Inicial}

Este princípio reitera um fato conhecido de negociadores experimentados: quem inicia uma negociação com altas demandas tem maior probabilidade de alcançar um acordo que the seja benéfico.

As explicações para este fato advêm da compreensão de que se está informando a outra parte de que as suas expectativas de ganhos sáo elevadas; e, em segundo lugar, ao sair com uma posição de demanda alta, é maior a margem a ser negociada, como também há mais tempo para estudar a posição real da contraparte.

No caso do setor público, é importante lembrar sempre que, por princípio constitucional, os interesses públicos prevalecerão sobre os privados ou particulares. Isto é válido sempre e a não-observância deste princípio tem causado sérios danos para sociedade brasileira nos últimos anos. Um exemplo recente foi o processo de investigação parlamentar (CPI) envolvendo empresários, deputados, senadores e funcionários públicos na elaboração do Orçamento da Uniâo. Pelas investigaçōes, a sociedade tomou conhecimento de como se processam as 'negociaçōes' ilegais, em que os recursos públicos são desviados de suas destinações sociais para atender interesses particulares.

\section{Posições e Modos de Negociação}

A posição estratégica do dirigente público, frente ao processo de negociação, deve estar orientada para:

a) selecionar o modo de negociação adequado para a situação ou, se não for possível, criar as condições apropriadas para a sua adoção;

b) aplicar as táticas adequadas dentro do modo escolhido, evitando uma transição indesejada para outro modo. 
O início deve ter atençáo especial do gerente. Nesta fase, as decisōes tomadas na mesa poderão afetar a agenda e o modo de negociar de todo o processo. Quase sempre se dá de modo competitivo, em consequêência da aplicação do princípio da alta demanda inicial. Trata-se de pedir o impossível; cabe ao condutor do processo dirigir as discussões para chegar ao modo coordenativo de negociar.

As condiçōes socioeconômicas e políticas fazem com que a maioria dos processos de negociação tenda a ocorrer de forma competitiva. Porém, isto não deve desestimular o dirigente da tentativa de obter pequenos acordos no decorrer do processo, o que pode facilitar ou encaminhar para resultado futuro mais equilibrado entre as partes. Nas negociações coletivas de trabalho, é freqüente que os dirigentes sindicais adotem posiçōes públicas muito conflitivas, reforçando a imagem junto a seus representados. Isto pode fazer com que todo o processo se dê dentro de um modo competitivo de negociar.

Em todos os modos de negociação, quatro critérios devem ser atendidos para que se considere aceito o processo:

- deve-se chegar a um acordo inteligente que contenha uma abordagem ampla e completa do problema negociado;

- os interesses legítimos das partes estão contidos no acordo;

- no acordo resolvem-se os interesses em conflito de forma justa, representando possibilidade de resolução definitiva do problema em questão;

- no acordo estăo considerados os interesses da comunidade com maior benefício dos compromissos estabelecidos.

O acordo conseguido deve ser duradouro, porque é respeitado e respeitável ao longo do tempo. O resultado é eficiente, pois implica o menor gasto e sacrifício possivel. É amigável, porque melhora ou ao menos não piora as relaçōes entre as partes negociadoras. A maneira mais comum de negociação é tomar e depois ceder posiçóes sucessivamente.

A forma escolhida para executar esta tática pode variar entre suave, gentil, agradável; não vendo a contraparte como inimiga, centrando a atenção na matéria a ser negociada e não na pessoa que negocia, e uma dura, agressiva, cujo objetivo é a vitória - as pessoas são adversários a serem derrotados - a pressão e a ameaça são usadas com freqüência, radicaliza-se na posição.

Qualquer das condutas pode provocar resultados positivos. O importante, no entanto, é ter em mente que o que interessa é um resultado inteligente, completo e duradouro, e não uma derrota ou vitória dentro do processo.

No caso do dirigente público, deve-se pensar, sempre, ao escolher uma posição dentro de uma negociação, se o confronto beneficia ou prejudica o usuário do serviço e relacionar este resultado com o que acontecerá se for obtido um acordo sobre aquele ponto.

É sempre bom considerar que sentimentos pessoais de vitória ou derrota podem provocar ressentimentos e sofrimentos que, se não elaborados, podem, além de provocar impedimentos desnecessários para a evolução do processo de negociação em direção ao interesse público, provocar rupturas nas relaçōes pessoais dos negociadores. 


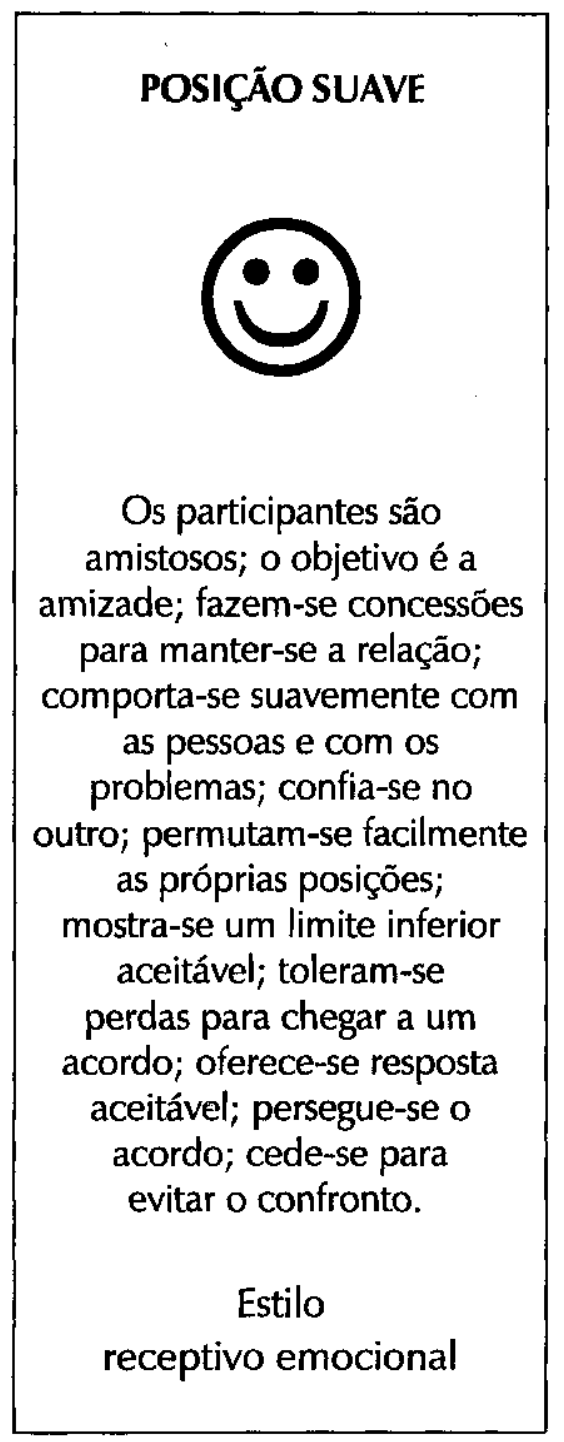

\section{POSIÇÃO DURA}

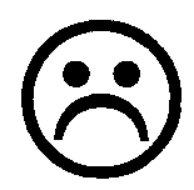

Os participantes são adversários; o objetivo é a vitória; exige-se concessão como condicionante da relação; comporta-se duramente com as pessoas e com o problema; desconfia-se dos outros; radicaliza-se nas próprias posições; esconde-se o limite inferior aceitável; exigem-se ganhos para chegar a um acordo; ameaça-se para chegar a respostas desejáveis; insiste-se na posição; pressiona-se para ganhar o duelo.

\section{Estilo}

racional assertivo 


\section{Táticas e Técnicas}

As táticas refletem as posições sobre o manejo das reações dos atores envolvidos e podem ser tão variadas quanto as incertezas que o gerente deve enfrentar em um processo de negociação. Podem-se observar dois tipos básicos de conduta ou estilo de negociação: um de posição suave outro de posição dura. O fundamental é que o negociador escolha as táticas correspondentes aos estilos que podem produzir maior impacto durante suas intervenções em cada momento do processo.

As táticas de posição suave mantêm as boas relações acima dos objetivos propostos para solucionar problemas. Isto implica um grande risco de não alcançar os objetivos da negociaçăo, o que produz algum tipo de tensăo. Por outro lado, na opção pela posição dura, só interessa ganhar, o que também pode pôr em perigo o processo, porque os acordos alcançados geralmente não serão inteligentes, nem duradouros, tampouco satisfarão a ambas as partes.

A posição dura se caracteriza pelo uso de um estilo racional/assertivo, e a posição suave por um estilo receptivo/emocional nas interações entre os atores da negociação.

No estilo racional/assertivo, utilizam-se mecanismos de buscar acordos como dogmatismo, coerção, argumento de autoridade superior, persuasão e sanções (táticas duras). No estilo receptivo/emocional, aplicam-se mais a razão, coalizão e o bom relacionamento (táticas suaves).

\section{Tática Dura}

O uso de táticas duras ou competitivas tem por objetivo aplicar alguma forma de coerção ao opositor, para que se outorguem concessões no modelo competitivo de negociação.

A efetividade destas táticas depende da credibilidade de quem as utiliza: essa, por sua vez, está vinculada a outros fatores, como reputação que tenha construído, do que se diz sobre elevada condição ou categoria, dos recursos com que conta para cumprir as ameaças e seu compromisso público com as posições que defende.

A força motriz das negociações competitivas é o desejo dos negociadores de manter a imagem de firmeza. As táticas aplicáveis neste modo de negociação estão orientadas para manter e reforçar esta imagem.

Todas as táticas duras são perigosas, podem provocar distanciamentos, paralisar a negociaçáo e, até mesmo, causar o abandono do processo pela outra parte. Sua utilização, no modo coordenativo, pode provocar uma transformação para o modo competitivo, ou de concepção unilateral. Por tais razōes, só devem ser utilizadas no modo competitivo. A seguir, descrevem-se seis táticas coercitivas:

- Impor pressão de tempo - Trata-se de criar para a contraparte a impressão de que os custos de seguir negociando são elevados. Uma forma usual é a fixação de um limite para estabelecer o acordo. Esta tática é uma das mais populares no modo competitivo. 
- Parecerfirme-Procura-se manter uma imagem de dureza. Implica que toda concessão deve ser plenamente justificada. No caso de se outorgar concessão, é possível evitar que produzam perda de imagem mediante: a) separação do resto da negociação (eu faço agora, porém, que não se repita); b) afirmar que se produzem baixas 'circunstâncias' especiais; e c) criar amenidades para estabelecer uma impressão de dureza.

- Reduzir a resistência do contrário a conceder - Isto pode lograr-se mediante: defesa simples do caso (persuasão), amenidade que tenha credibilidade, o que pode ser perigoso, ou por meio de um integrante da equipe que tenha sido designado como o 'duro', e, ainda, mediante promessas de que as concessões serão compensadas.

- Utilizar proeminências - Esta tática pode ser aplicada para superar situações de estancamento, e se refere a uma proposição alternativa e argumentações com base em conceitos como autoridade, justiça, igualdade, nacionalismo, desenvolvimento econômico, democratização da saúde que: a) usufruam privilégios ante os olhos de ambas as partes, seja porque invocam princípios ou algum precedente notório; b) geram expectativas similares nas partes.

Devido à incapacidade das partes em opor-se publicamente a uma alternativa 'proeminente', é possivel superar conflitos e gerar compromissos que facilitem o progresso da negociação para um acordo.

- Desenvolver uma relação agradável - Prover as amenidades, escolher um lugar agradável para a negociação, sugerir que sejam trocados os papéis ('...ponha-se em meu lugar...'). Esta tática é perigosa, pois se tem verificado que se pode ser vítima desta argumentação ao desenvolver um sentimento amistoso ao contrário. Também, é possível que esta tática seja interpretada pela contraparte como suborno, por exemplo.

- Reduzir ressentimentos na contraparte - Trata-se de eliminar a percepção de que a conduta adotada é de livre e espontânea vontade. Indica-se que as pressões são mesmo provenientes de fatores externos (um 'não pode ceder'). Outra possibilidade é alegar a imposição de pressões de maneira indireta, por exemplo, fixar reuniões em horas (noites, fins de semana) que gerem pressões de tempo na contraparte, sem que, naturalmente, pareça culpa do outro.

Além das táticas anteriores, podem-se mencionar outras naturais em situação aguda de confronto. Refere-se à busca de mediadores sobre a matéria - se tiverem por objetivo facilitar trocas ao término das discussōes; do processo - se tiverem por objetivo modificar o mecanismo de negociação. (Além do uso de mediadores, também pode-se recorrer a árbitros).

\section{Táticas Suaves}

As táticas suaves são ações orientadas para estabelecer e preservar o modo de negociação de concessão. Além das atividades que podem estar relacionadas à troca livre de propostas, pode-se falar de táticas de alto, médio e baixo risco, em referência ao perigo de perda de imagem e aos custos reais, quando se trata de negociar em forma de concessão. 
As táticas de alto risco correspondem a outorgação de concessões dramáticas, com a expectativa de que o outro vá corresponder sobre a hipótese de que isso reforçará a confiança mútua.

As de médio risco baseiam-se em ações reversíveis, especialmente quando a confiança no oponente é frágil. Estão incluídas comunicações indiretas por meio de mensageiro, emissão de sinais, fracionamento de concessões, discussões informais em corredores.

Preferem-se táticas de baixo risco quando o perigo de perder a imagem é particularmente sério. Podem-se incluir, entre estas, a busca de mediadores e a combinação de risco moderado (utilizar um intermediário para iniciar uma conversa informal).

Em geral, a escolha do modo de concessão está apoiada em aspectos como a existência de oportunidades de firmar acordos; percepções de injustiça em direção a outra parte ('... trate-o muito mal ...'); a existência de relações paralelas que devem ser mantidas em bons termos (outras possíveis cooperações) e a percepção de que a contraparte está por alcançar o limite de suas concessões.

O modo de concessão unilateral só é factível em situações em que uma negociação abre a possibilidade de aumentar os recursos a repartir. Contudo, o contrário não é certo, dado que existem situações nas quais o modo competitivo é estável.

Em geral, o importante dentro da primeira posição suave é evitar que se transforme em competitiva, mediante: a) participação ativa em discussóes para resolver diferenças e gerar alternativas de satisfação mútua e b) rejeição de táticas que possam ser interpretadas como competitivas. 
Táticas para as Etapas da Negociação

\begin{tabular}{|c|c|c|c|}
\hline ETAPA & AÇÃO & ESTILO & TÁTICA \\
\hline PAUTA & $\begin{array}{c}\text { CRIAR } \\
\text { AMBIENTE } \\
\\
\text { DEFINIR } \\
\text { PROBLEMAS }\end{array}$ & $\begin{array}{l}\text { RECEPTIVO } \\
\text { EMOCIONAL } \\
\text { RACIONAL }\end{array}$ & $\begin{array}{l}\text { - conseguir local } \\
\text { adequado } \\
\text { - buscar momento } \\
\text { oportuno } \\
\text { - selecionar atores } \\
\text { pertinentes } \\
\text { - criar clima de confiança } \\
\text { - identificar interesses } \\
\text { comuns } \\
\text { - não culpar e nem } \\
\text { ridicularizar a contraparte }\end{array}$ \\
\hline DEFINIÇÃO & $\begin{array}{l}\text { IDENTIFICAR } \\
\text { EXPECTATIVAS E } \\
\text { RECURSOS } \\
\text { ESTABELECER O } \\
\text { OBJETO } \\
\\
\text { ACORDAR } \\
\text { CRITÉRIOS }\end{array}$ & $\begin{array}{l}\text { RECEPTIVO } \\
\text { RACIONAL }\end{array}$ & $\begin{array}{l}\text { - colocar-se na posição } \\
\text { da contraparte } \\
\text { - precisar sua própria } \\
\text { posição } \\
\text { - separar o problema das } \\
\text { pessoas } \\
\text { - centrar-se em interesses } \\
\text { comuns } \\
\text { - insistir no uso de } \\
\text { critérios indepcndentes } \\
\text { - manter-se aberto à } \\
\text { razão e năo ceder diante } \\
\text { de pressão }\end{array}$ \\
\hline AJUSTE & $\begin{array}{c}\text { ACORDAR } \\
\text { OBJETIVOS } \\
\\
\text { GERAR } \\
\text { ALTERNATIVAS } \\
\text { ACEITÁVEIS }\end{array}$ & $\begin{array}{l}\text { RECEPTIVO } \\
\text { RACIONAL } \\
\text { RECEPTIVO } \\
\text { RACIONAL }\end{array}$ & $\begin{array}{l}\text { - identificar valores } \\
\text { comuns } \\
\text { - avaliar estratégias e } \\
\text { recursos } \\
\text { - centrar-se nos interesses } \\
\text { que estão por trás das } \\
\text { posições } \\
\text { - usar procedimentos } \\
\text { imaginalivos em busça de } \\
\text { soluçōes de benefício } \\
\text { comum } \\
\text { - explorar e misturar uma } \\
\text { ampla gama de opções }\end{array}$ \\
\hline COMPROMISSO & $\begin{array}{l}\text { OBTER ACORDOS } \\
\text { CONTROLE } \\
\text { ESTRATÉGICO }\end{array}$ & $\begin{array}{l}\text { RECEPTIVO } \\
\text { RACIONAL } \\
\text { RACIONAL }\end{array}$ & $\begin{array}{l}\text { - selecionar a melhor } \\
\text { opção para um acordo } \\
\text { negociado } \\
\text { - considerar a opçăo } \\
\text { como um todo: acordo } \\
\text { integral } \\
\text { - clarcar os } \\
\text { compromissos acordados } \\
\text { - verificar satisfaçăo } \\
\text { mútua }\end{array}$ \\
\hline
\end{tabular}




\section{A Negociação com Princípios sobre Pressupostos}

Para que não se tenha de escolher entre negociar com posições duras ou suaves, pode-se combinar o enfoque sobre as posiçōes e táticas de negociação, e adotar o modo coordenativo.

A resposta sobre maior conveniência de utilizar a negociação por posições suaves ou duras pode ser 'nenhuma'.

No método de 'Negociação de Princípios', desenvolvido por William Ury e Roger Fisher, considera-se alternativa eficaz de realizar negociaçōes no modo coordenativo à margem das posiçōes, com táticas suaves sem correr os riscos comentados, para se conseguirem acordos inteligentes, duradouros e amigáveis.

Este método, denominado 'negociação de princípios' ou 'negociação dos méritos', pode reduzir-se a quatro pontos básicos. Neles, define-se um método de negociaçăo direto que pode ser utilizado em qualquer circunstância. Cada ponto trata com um elemento básico da negociação e sugere o que se deve fazer a respeito.

\section{Pessoas - separar o problema das pessoas}

Separar as pessoas dos problemas implica conduzir problemas com a percepção e as emoçōes. Antes de abordar o problema objeto da negociação, o 'problema humano' deverá ser separado e tratado especificamente. Quanto à percepção, é necessário colocar-se na posição da contraparte e não tentar culpá-la por seus problemas, ajudá-la a participar e evitar que se exponha ao ridículo, fazendo suas propostas de acordo com seus valores. Por outro lado, trabalhar com as emoçōes compreende reconhecer e entender os sentimentos das partes envolvidas na negociação, permitir que deixem escapar a tensão, não se apressar em reagir frente às explosŏes emocionais e considerar a possibilidade de oferecer desculpas. Não se deve, tampouco, atacar as pessoas porque, além de provocar atitudes defensivas, deixa resíduos de hostilidade que podem interferir no processo de firmar acordos duradouros e amigáveis.

Além do propósito de separar as pessoas dos problemas, é mais do que necessária a comunicação eficaz, que compreende a necessidade de escutar, tornar claras as próprias emoçōes e falar com um propósito definido. Os negociadores devem se ver trabalhando juntos, enfrentando um problema comum, e não agredindo uns aos outros.

\section{Interesses - concentrar-se nos interesses e não nas posições}

Concentrar-se nos problemas que estão por trás das posições, para superar os inconvenientes de concentrar-se nas posições tomadas pelos atores, quando o objetivo da negociação é satisfazer interesses subjacentes. Reconhecem-se três tipos de interesses: compartilhados, diferentes e opostos. Tanto os compartilhados como os diferentes, porém complementares, podem levar a acordos inteligentes que satisfaçam as partes - precisamente porque os interesses diferentes podem tornar possivel um 
acordo acumulativo. Em uma negociação ocasional oculta-se o que se quer realmente; comprometer-se com posições não garante um acordo realmente satisfatório.

Teoricamente, é óbvio que interesses compartilhados ajudam a produzir um acordo. Por definição, uma idéia que os atenda é boa para ambas as partes. Contudo, na prática, a imagem parece menos clara; por exemplo, na metade de uma negociação sobre um valor, os interesses compartilhados podem não ser óbvios e apropriados. Como, então, buscá-los?

Além do interesse de evitar perdas conjuntas, quase sempre existe a possibilidade de um ganho conjunto. Isto pode desenvolver uma relação mutuamente vantajosa, satisfazendo as partes com uma solução criativa.

Vale a pena recordar alguns pontos sobre interesses compartilhados. Primeiro, estão latentes em cada negociação, e podem não estar claros de imediato. É bom perguntar-se: Temos interesse compartilhado em manter nossa relação? Que oportunidades existem para cooperação e benefício mútuos? Em que custos incorreremos se terminarem as negociações? Existem princípios comuns, como um serviço justo, que ambos possamos prestar?.

Segundo, os interesses compartilhados são oportunidades, não resultados da sorte. O negociador tem de dar utilidade a eles. Ajuda muito torná-los claros e formulá-los como objetivos compartilhados, fazê-los concretos e orientados para um futuro de benefício comum.

Terceiro, dar importância aos interesses compartilhados pode fazer a negociação mais fluida e mais amigável. Os náufragos em um bote salva-vidas, no meio do oceano, com rações limitadas, subordinarão suas diferenças sobre a distribuição do alimento aos interesses compartilhados de chegar à costa.

\section{Opçōes - criar alternativas antes de decidir o que fazer}

Gerar alternativas para benefício mútuo corresponde a imaginar e propor opçōes para um acordo possível, e logo desfazer as diferenças para chegar a um acordo ótimo. A geração de soluções viáveis tem como base desenvolver ampla gama de opçōes que despertem interesse comum e reconciliem interesses em conflito, usando procedimentos criativos.

Acordos 'frágeis' podem aumentar o número de idéias na negociação.

Quando é possível haver um acordo permanente, um acordo provisório também é viável. Se alguma das partes não chegar a um acordo de primeira ordem, poderá chegar a um de segunda ordem - assentir no que discordam, de tal forma que todos conheçam os assuntos em disputa, que nem sempre estão claros.

Também é útil considerar a possibilidade de variar não só a intensidade de um acordo, como também seu alcance. Pode-se, por exemplo, 'dividir' um problema em unidades menores, mais fáceis de se trabalhar. Um acordo pode ser parcial, conter somente alguns pontos selecionados. É possível, também, que seja aplicado em certa área geográfica e pode valer por um certo período. 
É estimulante, ainda, perguntar como se pode expandir o assunto para que o acordo se torne mais atrativo. Em geral, supōe-se que os problemas surgem das diferenças entre as partes. Contudo, elas podem levar, também, à solução.

Os acordos ocasionais se baseiam em desacordos. As diferenças de fé proporcionam as bases para o trato. Em muitos acordos criativos, reflete-se o princípio de buscar acordos a partir das diferenças. As diferenças de interesses e crenças tornam possivel que um objeto seja de grande benefício para uma das partes, porém de baixo custo para a outra parte. Nisto está o potencial da vantagem em negociar para ambas as partes: o risco pode ser trocado pelos benefícios.

Uma forma de transformar diferenças em interesses é gerar várias opçōes aceitáveis para uma das partes e pedir à outra que selecione uma. Pode-se, então, trabalhar um pouco mais esta opção, e apresentar outra vez as outras propostas, fazendo o mesmo pedido.

Sintetizando, na gama de opções para chegar a um acordo a partir das diferenças, é necessário intercambiar variações em interesses; o valor dos recursos ou o poder no tempo, os prognósticos, a aversão ao risco e as crenças.

\section{Critérios - insistir para que os resultados se baseiem em critérios objetivos independentes}

O uso de critérios independentes é um dispositivo de medida com valores externos mas compartilhados, juízo científico, reciprocidade, custos, tradição e oportunidade, dentre outros. Se se discute sobre esses critérios e princípios, independentemente da vontade de cada uma das partes, nenhuma delas tem de ceder frente à outra; ambas podem remeter-se para uma soluçăo justa.

Freqüentemente, os negociadores tratam de decidir sobre os possíveis acordos mediante a negociação de posiçōes - em outras palavras, falando sobre o que estáo dispostos a propor e a aceitar. O produto é resultado da interação das vontades, quase como se os negociadores estivessem com listas vazias, sem história, sem cultura e sem princípios éticos.

Negociar diferenças de interesses com base no poder da vontade tem um custo elevado, porque a negociação, provavelmente, não será amigável nem deverá ser produto de confrontação de vontades. Logo, a solução é negociar sobre alguma base independente da vontade de qualquer parte, com base num critério objetivo.

Para produzir um resultado independente das vontades, devem-se utilizar princípios ou procedimentos justos, resolvendo conflitos de interesses nas questôes substanciais do processo de negociação.

Geralmente, encontra-se mais que um critério objetivo disponível de base para um acordo. No mínimo, os critérios devem ser independentes da vontade de cada parte. Para assegurar um acordo inteligente, os critérios devem ser independentes da vontade, legítimos e práticos, aplicando-se, ao menos em teoria, a ambas as partes. 
Ao se chegar a um acordo discutindo sobre critérios objetivos, também fica reduzido o número de vezes em que cada negociador tem de comprometer-se e depois ceder conforme o movimento em direção a um acordo. Na negociação por posições, os negociadores passam a maior parte do tempo defendendo suas posições e atacando a do outro lado. Ao se utilizarem critérios objetivos, tende-se a aproveitar mais o tempo, falando sobre princípios e soluçōes possíveis.

Os critérios independentes são ainda mais importantes para a eficiência quando a negociação envolve mais de duas partes. Neste caso, a negociação por posições se encontra em um ponto mais crítico. Requer coalizão entre as partes; e se mais partes tenham acordado uma posição, mais difícil será a troca.

Supondo que o êxito de uma negociação dependa de que a outra parte tome a decisão que se quer, deve-se fazer o possível para que essa tomada de decisão seja fácil. No lugar de tornar as coisas difíceis para a outra parte, deve-se confrontá-la com uma solução que seja tăo pouco dolorosa quanto possível.

A maioria das pessoas está muito influenciada pelas próprias noções de legitimidade. Uma forma efetiva de desenvolver soluções fáceis de serem aceitas pela outra parte é primeiro ajustá-las para que sejam consideradas legítimas. É mais provável que a outra parte aceite uma solução se esta lhe parece justa, legal e honorável.

Poucas coisas facilitam uma decisão tanto como o precedente. Uma decisão ou declaração que se tenha tomado em situação similar é boa base para um acordo. Isto proporciona um critério objetivo e independente. $\mathrm{O}$ reconhecimento do provável desejo de serem consistentes - pensando-se sobre o que eles ou outros tenham feito ou dito - ajudará a gerar opções aceitáveis para ambos os pontos de vista. 
POSIÇÃO DURA

Os participantes

são adversários; o

objetivo é a

vitória; exige-se

concessão como

condição;

comporta-se

duramente com as

pessoas e com o

problema;

desconfia-se do

outro; radicaliza-se

nas próprias

posiçôes;

engana-se sobre o

limite inferior

aceitável; exigem-se

ganhos para

chegar a um acordo; ameaça-se para

obter as respostas

desejadas;

insiste-se na

posição;

pressiona-se para

ganhar o duelo.

\section{NEGOCIAÇÃO COM PRINCÍPIOS}

Os participantes solucionam

problemas; o objetivo é um acordo inteligente, duradouro e amigável; separam-se as pessoas dos problemas; comporta-se suavemente com as pessoas e duramente com os problemas;

procede-se independentemente da confiança; centra-se em interesses, não em posiçôes; evita-se adotar um limite inferior; geram-se alternativas para benefício mútuo; desenvolvem-se múltiplas opções para escolher; insiste-se em critérios objetivos; trata-se de

buscar um compromisso satisfatório. 


\section{Os Truques Sujos}

Ainda que se tenha tido o cuidado deliberado de abordar o tema sem proporcionar 'receitas' nem minimizar o correto desenvolvimento das habilidades gerenciais para a negociação, na continuação serão apresentadas algumas reflexões e considerações práticas sobre o manejo dos chamados 'truques sujos' que eventualmente são utilizados, por considerá-las úteis para o desenvolvimento da capacidade para gerenciar negociaçōes.

Existem muitos truques e táticas que se podem usar para tirar proveito de uma negociação. Estes vão desde o abuso psicológico até várias formas de pressão prática; podem ser ilegais, pouco éticos ou só desagradáveis. Seu propósito é de ajudar os usuários a 'ganhar' uma vantagem substancial em um duelo de vantagens sem princípios. Pode-se considerar uso destas táticas negociação enganosa.

Quando se reconhece que está sendo utilizada a tática da negociação enganosa, a maioria dos atores de uma negociação responde, normalmente, procurando-se pôr um fim neste tipo de negociação. $O$ provocar ou ser provocado não é nada agradável. Pode-se dar à outra parte o benefício da dúvida - por hora espera-se o melhor e se permanece calado - ou indignar-se e prometer-se nunca tratar com isto outra vez. A maioria das pessoas responde desta forma porque espera que, se não pode ceder desta vez, a outra parte se acalmará e não voltará com mais truques. Algumas vezes isto funciona, na maioria das vezes falha.

A segunda forma comum de responder é pagando com a mesma moeda. Se a contraparte começa agressivamente alto, a outra parte começa afrontosamente baixo. Se uns se comportam de forma enganosa, os outros também o fazem. Se uns ameaçam, outros contra-ameaçam. Se uns se fecham em suas posiçōes, os outros se escondem mais profundamente nas suas. Ao final alguém cede, ou a negociação é suspensa.

Tais táticas enganosas são ilegítimas porque não cumprem com a condição de reciprocidade. Estão desenhadas para que sejam utilizadas por apenas uma parte; espera-se que a outra parte não perceba tais táticas ou que, se as percebe, as tolere. As táticas da negociação enganosa são as de fazer propostas de um só lado sobre o procedimento de negociar, sobre o jogo da negociação que as partes vão jogar. Como contraponto, dever-se-á insistir em uma negociação de princípios sobre o processo de negociação, para examinar e acordar a legitimidade dos procedimentos e táticas que se vão utilizar.

Existem três passos ao negociar as regras do jogo da negociação quando a outra parte aparenta estar usando táticas enganosas: a) reconhecer a tática; b) tratar o assunto de forma explícita e questionar a legitimidade; c) negociar sobre a conveniência da tática em questão.

É preciso saber o que está se passando para se fazer algo a respeito. 'Há necessidade de aprender a detectar os artifícios que indiquem engano, aqueles que produzem incômodo, e aqueles que provoquem o fechamento da outra parte em sua posição. Existem ocasiōes em que só o fato de reconhecer uma tática provoca sua neutralização. Dando-se conta, por exemplo, de que a outra parte está atacando em nível pessoal com o objetivo de invalidar um juízo, pode frustar um esforço. 
Depois de reconhecer a tática enganosa, é conveniente expô-la diante da outra parte. Discutir a tática não só a faz menos efetiva como também pode fazer com que a outra parte se preocupe em respeitar os negociadores que tem em frente. $O$ simples fato de questionar o uso de uma tática pode ser suficiente para que se deixe de usá-la.

O propósito mais importante de expor e questionar a tática de forma explícita, sem enganos, é dar a oportunidade de negociar sobre as regras do jogo. Este é o terceiro passo. Esta negociação se centra em procedimentos em vez de na substância, mas o objetivo continua sendo o de produzir de forma eficiente um acordo inteligente (desta vez sobre o procedimento), duradouro e amigável.

As táticas enganosas podem ser divididas em três categorias: a) engano deliberado; b) guerra psicológica; c) táticas de pressão posicional. A seguir, dão-se alguns exemplos comuns de cada tipo; do mesmo modo, para cada um deles será mostrado como a negociação de princípios poderia se contrapor.

\section{Engano Deliberado}

Talvez a forma mais comum de truque sujo seja a falsa informação sobre as coisas, autoridades ou intenções.

- Coisas falsas - A forma mais antiga de negociar de maneira enganosa é fazer intencionalmente uma declaração falsa. Os perigos de ser enganado com uma declaração falsa são grandes. Que se pode fazer frente a isto?

Separar o problemas das pessoas. A menos que se tenha boas razões para acreditar em alguém, não se deve fazê-lo. Isto não significa chamar de mentirosa a contraparte, só significa fazer com que a negociação prossiga de forma independente da confiança. Não se deve permitir que alguém trate estas duas razóes como um ataque pessoal. A prática de verificar declarações sobre as coisas reduz o incentivo de enganar e o risco de ser enganado.

- Autoridade ambígua - A outra parte pode induzir que tenha a autoridade suficiente para chegar a um compromisso, quando na realidade não a tem. Depois de ter pressionado tanto quanto possa e se tenha trabalhado no que se acredita ser um acordo firme, a contraparte comunica que tem que mostrá-lo a alguém mais para que haja a aprovação.

Esta é uma situação perigosa que deve ser evitada, porque, se só uma parte tem autoridade para fazer concessôes, somente ela o fará.

Não se deve supor que a outra parte tenha autoridade total só porque está negociando, pois, mais tarde, o que se pensou ser um acordo pode ser tomado pela outra parte só como informação para estabelecer um limite inferior para futuras negociações.

É perfeitamente legal investigar a autoridade da outra parte. Sea resposta é ambígua, será possível desejar falar com alguém com autoridade real ou desejar que se reserve toda a liberdade para reconsiderar qualquer ponto em outra instância de negociação. 
Se inesperadamente é comunicado que o que se pensou ser um acordo está sendo tratado como base para negociações futuras, dever-se-á insistir na reciprocidade: tratar como um esboço com que nenhuma das partes esteja comprometida, de forma que ambas as partes estão livres para propor qualquer mudança.

- Intenções duvidosas - Quando se trata com possível falsidade nas intenções sobre alternativas do acordo, é possível elaborar critérios e mecanismos de verificação do cumprimento dentro do mesmo acordo. Para isto coloca-se uma dúvida de forma explícita e se negocia para conseguir uma garantia de cumprimento do acordo que eventualmente se obtenha.

- Não revelar tudo não é o mesmo que enganar - O engano deliberado sobre as coisas ou intenções é muito diferente do não revelar o pensamento de um determinado momento. Uma negociação de boa fé não requer revelação total. Talvez, a melhor resposta para este dilema seja revelar o respectivo pensamento a uma terceira parte que seja de confiança e que poderá decidir se existe uma zona potencial de acordo. Desta forma, é possível comportar-se com tranqüilidade sobre a informação que náo se tenha revelado.

\section{Guerra Psicológica}

Estas táticas estão desenhadas para fazer a contraparte sentir-se incomodada, com o objetivo de que haja um desejo subconsciente de terminar a negociação o mais rápido possível.

- Situações tensas - Muito tem sido escrito sobre as circunstâncias psicológicas nas quais a negociação acontece. Todo negociador deve ser sensível para ter que negociar em seu território ou no da contraparte, ou em um território neutro. Contrário ao que é geralmente aceito, algumas vezes resulta em vantagem visitar a outra parte em seu território, o que pode fazer com que se comportem com desenvoltura, estando assim mais abertos a sugestóes. Se for necessário, será mais fácil para alguém sair. Sem dúvida, quando se permite que a outra parte escolha o meio ambiente físico, é prudente avaliar previamente que efeitos isso pode ter no processo de negociação.

Perguntar a si mesmo se está sob tensão. Se a resposta for positiva, indagar o porquê: se o lugar é muito barulhento. Se não há espaço no momento para uma consulta mais ampla, é possível presumir que o espaço pode ter sido deliberadamente desenhado para que se queira concluir a negociação de pronto e, se for necessário, que se façam concessóes para atingi-lo.

Se o ambiente físico for prejudicial, é pertinente dizê-lo. Podem-se sugerir mudanças, retirar-se para outro lugar ou adiar a sessão. Em qualquer caso, o trabalho é identificar o problema, estar disposto a expô-lo a outra parte, e depois negociar na forma objetiva e baseando-se em princípios, com melhores condiçöes ambientais.

- Ataques pessoais - Além de manipular as condiçōes físicas, existem formas nas quais a outra parte pode utilizar a comunicação verbal e não-verbal para levar incômodo à contraparte. Podemos citar alguns exemplos: desconsiderar o nível ou 
condição de hierarquia de alguém fazendo-o esperar; interromper a negociação para tratar com outras pessoas; presumir que o outro não conheça o tema em questão; não escutar e fazer com que se repita o que foi dito; evitar deliberadamente olhar nos olhos. Em cada caso, reconhecer a tática ajuda a anular seus efeitos; expô-la abertamente muito provavelmente prevenirá que se volte a usá-la.

- O jogo 'do bem e do mal' - Uma forma de pressão psicológica que também encampa o engano é o jogo de papéis de 'o bem e o mal'.

Esta rotina é utilizada em uma negociação mais ou menos assim: dois atores do mesmo lado iniciam uma aparente discussão. Um toma uma posição dura; seu sócio se aflige e mostra maior flexibilidade. Finalmente interrompe, dirigindo-se à outra parte, atuando de forma razoável. A concessão não é grande, mas quase se assemelha a um grande favor.

A rotina do bom e do mau é uma forma de manipulação psicológica. Reconhecendo-a oportunamente não se cairá nela. Quando o bom faz sua jogada, simplesmente se faz a pergunta: Por que está tratando de ser razoável? Qual é seu princípio?

- Ameaças - As ameaças são uma das técnicas das quais se tem abusado mais nas negociaçōes. Uma ameaça parece fácil de se fazer - muito mais fácil que uma oferta. Tudo o que se gasta são algumas palavras e funciona, não há necessidade de se preocupar em levá-la a cabo. Porém, as ameaças podem gerar contra-ameaças que podem ir se alterando em uma espiral com potencial crescente e endurecer as posições, além de dificultar a relação.

As ameaças são uma forma de pressão que, às vezes, levam justamente ao oposto do que se pretende, criam resistências no outro sentido. Em vez de tornar fácil a tomada de decisão para a outra parte, torna-a mais difícil.

Os bons negociadores raramente recorrem a ameaças. Não necessitam fazê-las. Existem outras formas de comunicar a mesma informação. Parece apropriado destacar as conseqüências das ações da outra parte, podem-se sugerir aquelas que sejam independentes de sua vontade em vez daquelas que se podem levar a cabo. As advertências são mais legítimas que as ameaças e são invulneráveis a contra-ameaças.

Para que as ameaças sejam convincentes, devem ser comunicadas de forma convincente. Para neutralizá-las pode-se interferir no processo de comunicação: ignorar as ameaças, tomá-las como não-autorizadas; considerá-las simplesmente desapropriadas. Pode-se fazer com que o fato de comunicá-las já seja perigoso ou simplesmente infrutífero.

Algumas vezes as ameaças podem transformar-se em vantagem política. A melhor resposta a uma ameaça, com certeza, é basear-se nos princípios.

\section{Táticas de Pressão Posicional}

Este tipo de tática de negociação está desenhado para estruturar a situação de tal forma que só uma parte pode fazer concessões de forma efetiva. 
- Recusar-se a negociar - Uma variante deste truque é a de preestabelecer condiçóes mínimas favoráveis a uma parte como pré-requisito para negociar. O que se pode fazer quando a outra parte se recusa totalmente a negociar?

Primeiro, reconhecer a tática como possível artimanha de negociação: uma intenção de utilizar a participação na negociação como uma colaboração para se conseguir algumas concessōes substanciais.

Segundo, falar sobre a recusa a negociar, comunicando-se diretamente ou por meio de terceiros. Não é recomendável atacar pela recusa em negociar, é melhor encontrar quais são os interesses em não negociar.

Terceiro, sugerir algumas opçóes, tais como negociar mediante terceiras partes, por meio de cartas, ou motivando os indivíduos não envolvidos a discutir o assunto e propor alternativas de acordos.

Por último, insistir nos princípios: 'Esta é a forma que vocês gostariam de jogar?'; 'Vocês gostariam que nós fixássemos condiçōes pré-estabelecidas também?; 'Vocês querem que nós nos recusemos a negociar como vocês?'; 'Quais são os princípios que se pensa poder aplicar nesta situação?'

- Demandas extremas - Os negociadores a princípio começam com propostas extremas. Seu objetivo é baixar as expectativas da outra parte. Eles também acreditam que iniciar com uma posição extrema lhes dará um melhor resultado final, baseando-se na teoria de que as partes finalmente terminarăo dividindo a diferença entre suas posições.

Existem algumas desvantagens neste enfoque, inclusive para os negociadores enganosos. Ao fazer uma demanda extrema, que ambas as partes sabem que se abandonará, ocorre a diminuiçăo da credibilidade. Uma abertura deste tipo também pode acabar com a negociação; se a contraparte oferece tão pouco, pode-se pensar que não vale a pena tratar com ela.

Atrair a atenção para a tática funciona bem aqui. Pedir justificativa de sua posição em termos de princípios faz com que pareça ridícula até mesmo para a outra parte.

- Demandas escalonadas - Um negociador pode aumentar uma de suas demandas por cada concessão que faça em outra. Pode-se inclusive tratar novamente de assuntos que se pensou já estarem acordados. O benefício desta tática está na diminuição da concessão total e o efeito psicológico faz com que se queira chegar a um acordo rapidamente antes que as demandas aumentem mais.

Quando se reconhece isto, é necessário chamar.a atenção e talvez descansar, para considerar se a negociação deverá continuar e em que bases. Isto evita uma reação impulsiva e indica serenidade do próprio comportamento. E mais uma vez, insistir nos princípios, para que, quando se retorne às negociaçōes, qualquer interessado que chegar a uma solução se comporte mais seriamente. 
- Táticas de encadeamento - Esta tática busca criar condiçóes de compromisso extremo desenhadas para que seja impossivel ceder. Paradoxalmente, uma parte fortalece sua posição de negociação debilitando seu controle sobre a situaçáo, manifestando assim que está preso a outros compromissos que the deixam pouco espaço de concessão.

Em negociaçöes entre sindicatos e gerência, e em negociações internacionais, esta é uma tática comum.

Como as ameaças, as táticas de encadeamento dependem da comunicação. Em resposta a uma tática de encadeamento há um compromisso extremo, portanto, é possível também interromper a comunicação. Assim, pode-se interpretar o suposto compromisso de forma que o debilite. Como alternativa, pode-se desconsiderar e não levar o encadeamento a sério.

Também se pode resistir a este truque mediante uma proposta de princípios e a análise dos méritos do problema. Qualquer coisa que se faça, deve evitar que o suposto compromisso extremo seja a questão central, 'desenfatizando-o' para que a outra parte possa dar marcha à ré de forma decorosa.

- O sócio teimoso - Talvez a tática mais comum de negociação, utilizada para justificar o năo ceder ante demandas da outra parte, é manifestar que um não tem nenhuma objeção para adotar o acordo, mas que seu 'sócio teimoso' não o autorizará.

Uma vez reconhecida a tática, em vez de discutir um possível acordo com o outro negociador, provavelmente dever-se-á obter um acordo sobre o princípio subjacente - quem sabe por escrito -, e depois, se for possível, falar diretamente com o 'sócio teimoso'.

- Um atraso calculado - Com freqüência, uma parte tratará de retardar uma decisão que considere conveniente. Os sindicatos normalmente se propõem à negociação poucas horas antes que se instale a greve, contando com a pressão psicológica do pouco tempo disponível, para fazer mais flexível a gerência. Desafortunadamente, às vezes não se calcula bem e a greve se instala. Uma vez que tenha começado a greve, a gerência, por sua vez, pode decidir esperar por um momento que the seja mais favorável, tal como quando a sustentação para a greve se acabe. Esperar pelo tempo certo é um jogo muito custoso.

Além de explicitar as táticas de retardamento e negociar sobre elas, deve-se considerar e criar uma oportunidade favorável para que a outra parte se desvencilhe da tática. Buscar condiçôes objetivas que ajudem a estabelecer datas limites, tais como a data em que finaliza um contrato ou o final de uma sessão legislativa.

- 'Pegar ou largar' - Não há nada inerentemente mau ao enfrentar-se a outra parte em um dado momento com uma opção firme. Esta é uma forma eficiente de conduzir um negócio, mas não o é na negociação, não é uma tomada de decisão interativa em termos de reciprocidade. Tampouco há nada de mau em concluir uma longa negociação quando se considera pertinente, exceto que provavelmente se deveria utilizar uma forma mais amável. 
Como alternativa de reconhecer explicitamente a tática do 'pegar ou largar' e negociar sobre ela, pode-se ignorá-la primeiro. Continuar falando como se não escutasse, trocar o tema, quem sabe introduzir outras soluções. Ao se tratar da tática especificamente, é conveniente saber o que se perderá se não se chegar a um acordo e buscar uma forma que evite fazer papel ridículo, tal como uma mudança nas circunstâncias que permitirá dar 'marcha à ré'.

Finalmente, pode-se resumir o apresentado neste capítulo sobre os truques sujos com a seguinte recomendação: retire-se. Não seja uma vítima. Não ceda ante pressão, só ante a razão e em função de princípios.

Em princípio é difícil decidir o que significa negociar de 'boa-fé'. As linhas de negociação são traçadas em lugares diferentes. Podem ajudar na autoformulação perguntas como: 'Este é um enfoque que usaria se estivesse tratando com um bom amigo ou um membro da família?'; 'Se aparecesse nos jornais uma reportagem completa do que disse e fiz, me sentiria envergonhado?'; 'Na literatura novelesca, uma conduta como esta seria mais a de um herói ou a de um vilāo?'

Estas perguntas não têm intenção de reger o próprio comportamento com opiniōes externas, mas de esclarecer os próprios valores internos. Deve-se decidir por si mesmo sobre utilizar-se de táticas que se considerem inapropriadas e de má-fé, se a contraparte está utilizando.

Pode ser útil dizer no início da negociação, 'Olhe, eu sei que isto não é usual, mas quero conhecer as regras do jogo'. 'Estamos ambos tratando de chegar a um acordo inteligente tão logo e com o mínimo de esforço que seja possível?' 'Vamos jogar a 'negociação dura', onde as pessoas têm mais a perder do que a ganhar?' Qualquer decisão que se tome, tem que se estar preparado para lutar contra táticas de negociação suja. É mais fácil defender princípios do que uma tática ilegítima.

\section{Desenvolvimento de Habilidades}

Nas páginas anteriores, vimos acumulando elementos que podem ajudar a responder à pergunta: 'É possível melhorar as habilidades para gerenciar as negociações?' Acredita-se que existam numerosos elementos em uma negociação que podem ser manejados explicitamente e de forma proveitosa para as partes envolvidas.

Para todos os efeitos deste trabalho, consideramos que a gerência da negociação consiste no planejamento e realização de diversas ações anteriores, simultâneas e posteriores ao processo de negociação que contribuem para alcançar os objetivos esperados a partir da mesma. Quando as partes envolvidas representam instituiçōes, estas ações podem realizar-se em dois níveis: estratégico e tático.

O nível estratégico está intimamente ligado à política geral das instituições e tem maior importância durante as fases iniciais do processo de negociação. Portanto, a gestão de negociação em nível estratégico não se apóia em princípios específicos, mas em enfoques e metodologias de caráter geral.

No nível estratégico de gestão busca-se responder a perguntas como:

- Vale a pena negociar? Existem outras opçōes para obter o que se deseja?

- Quando negociar? Antes ou depois de um evento relevante? 
- Com quem negociar? Seleção da contraparte e se houver várias possíveis, em qual ordem?

- Como se constituem as equipes de negociação? Quem as constitui e que preparação devem fazer?

- Que estrutura organizativa apóia a negociação? Dentro da organização, quem deve apoiar os negociadores?

O nível tático, por outro lado, é importante durante o processo de negociação. Aqui o problema consiste principalmente na aplicaçáo de teorias e técnicas do comportamento humano e organizacional, além da intuiçăo gerencial, para um processo complexo de tomada de decisões.

No nível tático de gestão trata-se de responder a perguntas como:

- Que cláusulas estão-se negociando?

- Em que ordem duas cláusulas são negociadas?

- Como se negocia? Que regras o jogo pode ter, quais năo deve ter?

- Quais são os princípios, posições, estilos e técnicas de desenvolvimento no processo de negociação?

A ênfase deste capítulo sobre habilidades de negociação está no nível tático.

A habilidade de cada negociador pode melhorar se for possível observar e analisar o respectivo comportamento, a fim de garantir que a negociação conduzirá a um acordo inteligente e que satisfaça os interesses mútuos o suficiente para que o resultado possa ser duradouro e as relações sejam mantidas. Além disso, é necessário estar atento para que a melhor opção seja legítima para todos, que ninguém se sinta perdedor, e que os compromissos incluídos sejam bem estruturados, realistas e operativos.

Para melhorar a maneira de negociar deve-se primeiro entender como está-se fazendo no presente, para planejar um enfoque melhor para a próxima vez que se enfrentar uma situação similar.

Para obsenvar e analisar o seu comportamento e o dos outros, é útil primeiro dedicar alguns minutos para ordenar individualmente os próprios pensamentos e refletir; depois, dedicar um pouco de tempo para compartilhar e discutir com aqueles com quem se está negociando.

Ao observar e analisar uma negociação é útil fazer as seguintes perguntas:

- O que aconteceu? Quem disse e o que disse? (Dar exemplos específicos e utilizar as expressöes ao pé da letra tanto quanto seja possível, de maneira que as pessoas possam estar razoavelmente seguras de que estão descrevendo as posiçōes reais).

- Que opções foram colocadas? Considerar as opçôes dos negociadores que foram significativas: opçōes que afetam ou possam afetar o resultado.

- Que racionalizações e suposições se utilizam? Analisando as opções, refletir sobre os pressupostos que possam estar apoiando as mesmas. Analisar que racionalizaçăo levou à escolha do modo que foi feita (a negociação). 
- Que suposições alternativas puderam ser consideradas? Analisar as suposições e razões que outros tenham aplicado em situações similares e que puderam ser utilizadas.

- Quais as conseqüências? Descobrir as conseqüências das opções específicas colocadas e das adotadas.

- Que outras medidas alternativas existiam? Que opçōes alternativas poderiam ser escolhidas? Como foram vistas tais opçôes quando postas em ação? Quais poderiam ter sido suas conseqüências se as houvessem utilizado nesta negociaçăo?

Estes seis pontos de reflexão são bases de um processo de avaliação para a retroalimentação. O conteúdo da análise de avaliação poderia, de modo útil, concentrar-se em alguns dos seguintes aspectos:

- Que clima estabeleceram os negociadores?

- Que posição e modo de negociar adotou cada parte?

- Que fez cada negociador para seguir o caminho da negociação e mantê-la dentro de sua estratégia, em vez de apenas reagir um frente ao outro?

- Como foi a comunicação?

- Cada um entendeu o que a outra parte estava dizendo e por quê? Qual a eficiência do processo? Requereu esforço e tempo extraordinários?

- Como cada negociador estava tentando influir sobre o outro? Discutindo uma posiçăo ou raciocinando sobre as propostas? Explicando os interesses da outra parte e demonstrando que os entendeu claramente? Sugerindo novas opçóes de benefício mútuo? Utilizando critérios independentes de legitimidade?

- O que o surpreendeu, se é que algo o surpreendeu? Os outros pareciam estar surpresos?

- O que pareceu ser eficaz para chegar a um acordo? 


\section{Referências Bibliográficas ${ }^{7}$}

BACHARACH, S. B. Bargaining within Organizations. In: BAZERMAN, M. H. \& LEWIKI, R. J. (Eds.) Negotiation in Organizations. Beverly Hills: Sage Publications, 1983.

BACHARACH, S.B. \& EDWARD, J. L. Bargaining: power, tactics and outcomes. San Francisco: Jossey-Bass Publishers, 1984.

BARRENECHEA, J. J., TRUJILLO, E., URIBE, Y. A. \& CHORNY, H. Implicaciones para Planificación y Administración de los Sistemas de Salud. Columbia: Editorial Universidad de Antioquia, 1990.

BARTOS, O. How Predictable are Negotiations? Journal of Conflict Resolution, 11, 1967.

BERKELEY, A. \& COLOSI, T. Negociación Colectiva: el arte de conciliar intereses. México: Editorial Limusa, 1989.

COHEN, H. Todo Es Negociable. Caracas: Editorial Planeta, 1983.

CROSBY, B. El Análisis Político y el Sector Salud. Costa Rica: INCAE/Organización Panamericana de la Salud (OPS), 1990.

CROSS, J. Negotiation as a Learning Process. Journal of Conflict Resolution, 21, 1977.

CROWTHER, W., FLOR CUBERO \& SIBILLE, M. Estrategias de Información: un enfoque para la gestión publica. Costa Rica: ICAP. San José, 1989.

ELLSBERG, D. The Theory and Practice of Black-mail. Santa Monica: Rand, 1968.

FISHER, R.\& URY, W. Obtenga el Si: el arte de negociar sin ceder. México: Compañia Editorial Continental, 1984.

HARSANYI, J. Rationality postulates for bargaining solutions in cooperative and noncooperative games. Management Science, 9, 1961.

JANDT, F. E. Ganar Negociando. México: Editorial CECSA, 1986.

KENNEDY, G. Pocket Negotiator. Oxford: Basil Blackwell, 1987.

LAX, D. A., JAMES, K. \& SEBENIUS. The Manager as Negotiator: bargaining for cooperation and competitive game. New York: Free Press, 1986.

LEWIKI, R. J. Negotiation. Homewood: Irwin, 1985.

LOCKART, C. Bargaining in International Conflicts. New York: Columbia University Press, 1979.

MONSALVE, T. Estrategias y tácticas de negociación. Caracas: Publicación del Centro de Documentación del CLAD, 1988.

$\mathrm{NASH}$, J. The bargaining problem. Econométrica, 18, 1950.

ORGANIZACIÓN PANAMERICANA DE LA SALUD. Desarrollo y Fortalecimento de los Sistemas Locales de Salud: la administración estratégica. HSD/SILOS-2. Washington, D.C., 1992.

ORGANIZACIÓN PANAMERICANA DE LA SALUD. Proyecto Subregional de Desarrollo de la Capacidad Cerencial de los Servicios de Salud de Centroamerica. Desarrollo de los Sistemas Locales de Salud: marco de referencia subregional. PSDCG-T.2. Guatemala, 1992.

ORGANIZACIÓN PANAMERICANA DE LA SALUD. Proyecto Subregional de Desarrollo de la Capacidad Gerencial de los Servicios de Salud de Centroamerica. Marco de Referencia para el Desarrollo de la Capacidad Gerencial en Salud. PSDCG-T.9. Guatemala, 1988.

PRUITT, D. Negotiation Behavior. New York: Academic Press, 1981.

7 Faltam alguns dados nas referências que não puderam ser recuperados, uma vez que não se encontravam no original. 
PRUITT, D. Estrategic choice in negotiation. American Behavioral Scientist, 27 (2), 1983.

RAMIREZ, J. S. Red de Eslabonamiento Estrategico. INCAE, 1987. Adaptación al Sector Salud: OPS, 1990.

RAIFA, H. The Art and Science of Negotiation. Cambridge, New York: Academic Press, 1982.

RUBIN, J. Z. \& BROWN, B. R. The Social Psychology of Bargaining and Negotiation. New York: Academic Press, 1976.

RUBIN, J. Z. Negotiation: an introduction to some issues and themes. American Behavioral Scientist, 27 (2), 1983.

SCHOONMAKER, A. Negocie y Gane. Bogota: Editorial Norma, 1990.

TRUMP, D. El Arte de la Negociación. Caracas: Editorial Grijalbo, 1989.

VILLALBA, J. A Behavioral Framework for the Management of Technology Transfer Negotiation. Working Papers no 1635-82, MIT: Sloan School of Management, 1982.

WALTON, R. Conciliación de Conflictos Interpersonales: confrontaciones y consultoria de mediadores. Editorial Fondo Educativo Interamericano, 1973.

WHINHAM, G.. Negotiation as a management process. World Politics, 30, 1977.

ZARTMAN, W. Negotiations: theory and reality. Journal of international Affairs, 9, 1975.

ZEUTHEN, F. Problems of Monopoly and Economic and Economic Warfare. New York: Kelley, 1968. 


\section{COMENTÁRIOS FinaIS: dÚVIDAS MAIS COMUNS}

Visualizar objetivos básicos, centrados nos direitos dos usuários e nos interesses da cidadania; conhecer novas formas de administrar conflitos e relaçóes de trabalho no setor público; travar contato com as experiências desenvolvidas; conhecer um pouco do emaranhado jurídico envolvido com o tema; apreender novos conceitos, estudar argumentos, avaliações e análises políticas de autoria dos próprios protagonistas das experiências comentadas; introduzir modelos de gestão, aproveitando conhecimentos, estudos e experiências anteriores foram algumas das possibilidades que o trabalho pretendeu oferecer aos interessados.

Desvendar os melindres que envolvem os processos de negociação, tal como estudado nesta última parte do trabalho, pode contribuir, um pouco, para a capacitação de negociadores e aplicadores de modelos de gestão no setor público.

Aplicar tudo o que se defendeu, por intermédio da negociação de interesses legítimos, de forma competente e honesta, significa reunir condições para obter melhoria da qualidade dos senviços públicos e para conferir democracia a procedimentos essenciais ao exercício da cidadania.

Para este comentário, reuniu-se um rol de questōes que sempre surgem quando o assunto é gestão pública democrática e negociação de conflitos, devidamente acompanhado de respostas curtas e sintéticas, encerrando este trabalho com uma espécie de 'memória rápida' de alguns tópicos tratados nos capítulos anteriores.

1) $O$ administrador público não pode ser submetido a sistemas decisórios que venham a impeli-lo a praticar atos não previstos em lei. Nos sistemas que adotam a gestão participativa, como se dá o processo decisório diante dos princípios que regem a Administração Pública?

R. Em todas as experiências desenvolvidas, o sistema decisório adotado foi o da composição entre partes. Por ele, não há como impelir o administrador a praticar um ato não respaldado em lei. É bom lembrar, contudo, que o sistema não é contra as regras da administração, tampouco contra $o$ administrador ou as entidades sindicais. Muito menos contra os interesses dos usuários. É a favor da democratização dos processos decisórios. No setor privado, o processo de negociação também é resolvido por intermédio de composição das partes, nunca por votação entre capital e trabalho. 
2) Não há o risco de uma das partes, especialmente a Administração, ficar em minoria nos processos de negociação?

R. Já que o sistema decisório é por consenso, as decisōes não são tomadas por maioria de votos. Não há, então, motivo para preocupações quanto ao fato de o administrador encontrar-se em minoria ou maioria.

3) Como conduzir a participação e a tomada de decisões se houver vários órgãos da Administração participando?

$R$. Havendo mais de um órgão administrativo representado e ocorrendo divergência entre eles, pode-se optar pelas seguintes alternativas: suspendem-se os procedimentos e aguarda-se o consenso da administração, a favor ou contra. Ou, então, adotam-se as providências aprovadas apenas em relação ao órgão acordante.

4) E quanto à participação concomitante de entidades sindicais, sobreposições ou disputas de representação de bases entre elas, como são resolvidas?

R. Disputas de base sindical ou divergências de fundo acabam sendo resolvidas na Mesa. Contudo, o Sistema pode prever critérios para sua solução, a exemplo das providências adotadas na experiência do IAMSPE, que estabeleceu, para o caso de dúvidas, a observância aos princípios da legitimidade de representação e da vontade majoritária dos interessados. A assembléia do segmento afetado decide. Ainda assim, permanecendo questionamentos, podem ser aplicados critérios de aferição do grau de legitimidade como o número de filiados das entidades, sua tradição de luta no setor, o comprometimento com o processo.

5) Não há o perigo de tornar o sistema inoperante pelo excesso de participantes?

R. Quanto mais setores estiverem envolvidos e quanto maior for o grau de legitimidade das entidades que os representem, maior será a capacidade do sistema para envolver e obter compromissos. No IAMSPE e na Prefeitura Municipal de São Paulo, tanto as associaçōes locais de funcionários quanto os sindicatos, como o Sindicato dos Médicos e o dos Trabalhadores na Saúde integraram os procedimentos. A maioria das entidades participantes era filiada à CUT. Contudo, desconhecemos a ocorrência de problemas maiores nessa área.

6) Há inúmeros questionamentos sobre a legalidade de sistemas deste tipo. Afinal, órgãos públicos podem introduzir ou participar de procedimentos paritários de decisão?

$R$. Considerando tudo o que já foi dito sobre consenso e democratização do processo de tomada de decisões, importa registrar que o Sistema assemelha-se à participação da Administração Pública em inúmeros fóruns, nos quais também participam instituições de direito privado. Mesmo em fóruns de participação obrigatória, previstos em lei, como os Conselhos, por exemplo, onde há inclusive votação e as decisões não são tomadas necessariamente por consenso, o administrador somente encaminhará decisões que não firam as normas da Administração Pública. A mesma vigilância do administrador vale para as negociações, sendo mais fáceis, nestes casos, em vista da forma consensual de decidir. 
7) Qual a força das decisões adotadas nestes sistemas de gestão negociada?

R. Primeiro existe a força moral, decorrente do assentimento do administrador sobre a necessidade e a validade de se adotar determinada medida. Este compromisso moral e político é muito mais importante do que se imagina. Com base nele os petroleiros sustentaram, no ano de 1995, uma das mais longas greves da história sindical do país.

8) A força moral, isoladamente, não altera direitos. As decisões paritárias não têm forma prevista na legislação administrativa. Como proceder?

R. As formas das decisōes dependerão dos seus conteúdos. Decidida a matéria, as partes darão os encaminhamentos pertinentes às prerrogativas que detém. Exemplo: determinada decisão implica findar uma greve. Caberá ao sindicato encaminhar os procedimentos necessários para efetivar esta decisão. Caso o conteúdo implique aumento de vencimentos, o acordo estabelecerá o compromisso da administração específica em empenhar-se junto às instâncias competentes para efetivar a medida. Aumento de vencimentos depende de iniciativa das instâncias superiores do Poder Executivo e de aprovação de lei. Aparece, portanto, um coadjuvante que é o Congresso Nacional. Assim, na prática, a decisão da Mesa consiste, nesses casos, em encetar negociaçōes para, através do envio de projeto de lei do Executivo ao Legislativo, obter a forma legal necessária para dar respaldo à decisão.

9) Pode-se dizer, em conseqüência, que o Congresso Nacional é uma terceira parte nas negociações?

R. Quando o conteúdo da negociação envolver sua competência legal, sim. Caso contrário, não. Há matérias sobre as quais o Congresso detêm competência legal para propor projetos de lei. Outras, a iniciativa é do Executivo. Mas há uma infinidade de assuntos que podem ser tratados por meio de ordens de serviços, portarias, circulares internas, regulamentos, regimentos, decretos ministeriais etc. E são assuntos que estão na base de muitos conflitos no setor público. Concluindo, a decisão da Mesa gera o compromisso moral e político do administrador em introduzir a providência aprovada. $O$ veículo a ser utilizado será aquele mais adequado às normas do direito administrativo.

10) No caso do IAMSPE, as decisões são registradas em protocolos. Como isto é processado internamente na Administração. E com relação aos servidores, os protocolos geram, de fato, direitos?

R. No IAMSPE, a quase totalidade dos servidores era regida pelo regime da CLT. Os conflitos eram dirimidos apenas por intermédio de reclamações trabalhistas. Isto foi alterado. Os Protocolos da Mesa de Negociação trouxeram menção expressa da sua natureza contratual. Seu conteúdo adere ao contrato de trabalho. Também estabeleceram que os direitos e obrigações gerados poderão ser legalmente exigidos. Portanto os protocolos geram, claramente, direitos e obrigaçōes. É por meio da sua celebração que a negociação ganha caráter permanente, fugindo do vício exclusivista das campanhas salariais anuais. Os procedimentos internos da administração para processar as decisões adotadas são realizados na conformidade das normas legais de caráter administrativo. 
11) O que dizer sobre a decisão do Supremo Tribunal Federal de proibir o regime de negociação coletiva de trabalho no setor público?

R. A decisão do Supremo foi no sentido de esclarecer que a Justiça do Trabalho não detém competência legal para apreciar dissídios coletivos de trabalho do setor público. Não se aplicam, portanto, ao setor público, os conceitos clássicos da negociação coletiva de trabalho do setor privado, com todas as suas implicações. Isto está muito longe de significar que os administradores públicos não possam realizar negociaçōes para compor conflitos que interfiram na consecuçăo das finalidades administrativas. Ora, uma vez assegurados aos senvidores públicos o mais corporativo dos instrumentos organizativos (sindicatos) e o mais extremo dos recursos de pressão de que dispóem os assalariados (greve), não seria crível que o legislador ou o Poder Judiciário viessem a inibir a adoção de instrumentos capazes de compor conflitos e harmonizar as relaçōes de trabalho.

12) Não há necessidade de suporte legal específico para instituir mecanismos de negociação de conflitos no setor público ?

$R$. Depende do sistema que se deseja instituir. Entendemos que há, ao menos, cinco maneiras distintas de instituir sistemas de gerenciamento de conflitos. Uma é através da legislação. Outra, através de convênios. Uma terceira, por meio de contratos. Uma quarta que mistura a primeira com uma das demais. $E$ a quinta que combina todas as citadas. É necessário proceder à análises jurídicas minuciosas para encontrar-se a forma legal adequada aos instrumentos de gerenciamento de conflitos que se deseja introduzir.

13) Que assuntos podem ser tratados nas Mesas de Participação? Por que este Sistema é chamado de mão dupla?

R. Em princípio, qualquer assunto pode ser apreciado nas mesas de negociação, desde que relacionados aos objetivos conveniados. As partes estabelecerão, previamente, no documento que conterá as regras de funcionamento do Sistema, a sua competência material. É claro que decisōes sobre matérias não afeitas ao âmbito de competência legal das partes terão efeitos meramente políticos. O Sistema é chamado de mão dupla porque, ao contrário das características do setor privado, ambas as partes podem apresentar questôes para serem apreciadas na Mesa, possibilidade que permite ao administrador buscar ampliar as taxas de legitimidade e de credibilidade para suas decisōes. Lembremos, sempre, que o objetivo maior desses sistemas é a busca da qualidade dos serviços e a plena satisfação às demandas da cidadania. 


\section{Consideraçōes Finais}

A ocasião é apropriada para indicar aspectos do tema que tenham sido tratados no presente livro e que, por sua natureza, somam complexidade à tarefa de gerenciar a negociação. Toda a negociação é fundamentalmente um processo de troca de informação, onde existem incentivos para atuar tanto de maneira franca como enganosa. Frente a esta contradição, cada indivíduo e cada grupo atuará de maneira diferente e imprevisível. Esta dimensão interpessoal é talvez a menos controlável de uma negociação. Pouco servirăo as numerosíssimas recomendaçōes possíveis para o comportamento dos negociadores - e das equipes formadas - se não houver capacidade de pô-las em prática por razões interpessoais.

A ausência de teorias integradas e de validade universal determina que a formação de um negociador depende tanto da experiência - seja esta adquirida mediante simulações - ou em situações reais. O importante das simulações - com o auxílio de programas de computador e de casos - é que contenham suposiçōes incorporadas que apresentem uma situação objetiva, na qual se pode examinar tanto a própria conduta como a lógica do processo, como uma realidade, sem incorrer em custosos equívocos.

Para terminar, vale a pena reiterar um ponto que, por constituir um lugar comum, não deixa de ter imenso valor. Não existem recomendaçōes gerais que garantam um desempenho positivo em todas as situações. Provavelmente, o melhor que se pode fazer é reforçar a análise dos aspectos mais importantes, recordando que cada situação tem elementos únicos, e enfatizando a relação que pode existir entre a negociação e a estratégia institucional. Esta última estabelecerá quais são os interesses básicos que se devam defender e quais as posiçōes transitórias que se podem comprometer. 
Formato: $16 \times 23 \mathrm{~cm}$

Tipologia: Chianti

Papel: Pólen Bold $70 \mathrm{~g} / \mathrm{m}^{2}$ (miolo)

Cartão Supremo $250 \mathrm{~g} / \mathrm{m}^{2}$ (capa)

Fotolitos: Laser vegetal (miolo)

De Garcia Desenho e Produção (capa)

Reimpressão e acabamento: Millennium Print Comunicação Visual Ltda.

Rio de Janeiro, março de 2002.

Não encontrando nossos títulos em livrarias,

contactar a EDITORA FIOCRUZ:

Av. Brasil, $4036-1^{2}$ andar - sala 112 - Manguinhos

21040-361 - Rio de Janeiro - RJ

Tel.: (21) 3882-9039 e 3882-9041

Telefax: (21) 3882-9006 e 3882-9007

http//www.fiocruz.br/editora

e-mail: editora@fiocruz.br 